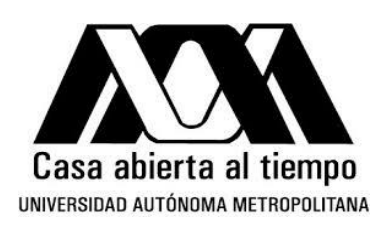

\author{
UNIVERSIDAD AUTÓNOMA METROPOLITANA \\ IZTAPALAPA \\ DIVISIÓN DE CIENCIAS SOCIALES Y HUMANIDADES
}

\title{
“LA FISCALIZACIÓN A LOS PARTIDOS POLÍTICOS EN MÉXICO: EL CASO DE LAS ELECCIONES FEDERALES DE 2012."
}

\author{
IDÓNEA COMUNICACIÓN DE RESULTADOS \\ PRESENTA: \\ LUIS FERNANDO ORDAZ BAUTISTA
}

2123802453

PARA OPTAR AL GRADO DE

MAESTRO EN ESTUDIOS SOCIALES

LÍNEA PROCESOS POLÍTICOS

DIRECTOR: DR. ALBERTO ESCAMILLA CADENA

JURADOS: DRA. JOSEFINA MALDONADO MONTES

Y DR. DAVID MORALES GONZÁLEZ

IZTAPALAPA, D.F., JULIO 2014. 
LA FISCALIZACION A LOS

PARTIDOS POLITICOS EN

MEXICO: EL CASO DE LAS

ELECCIONES FEDERALES DE 2012.

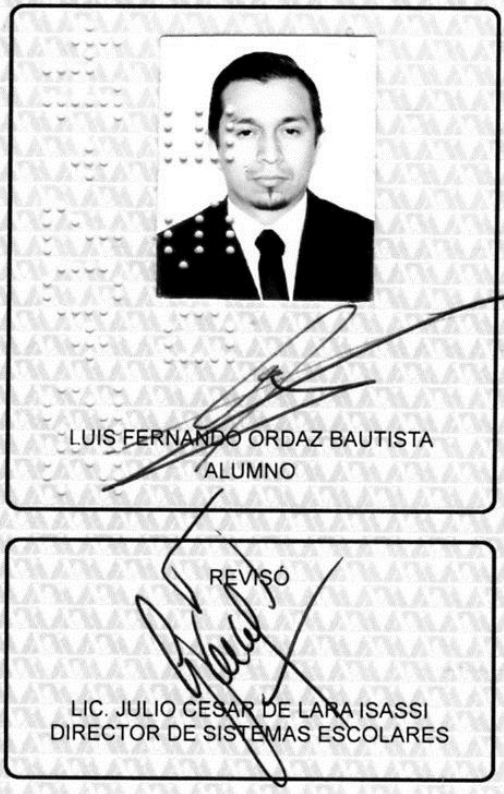

DIRECTORA DE LA DIVISIÓN DE CSH

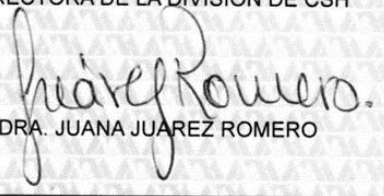

$x$ de acuerdo con el Reglamento de Estudios Superiores de la Universidad Autónoma Metropolitana, los miembros del jurado resolvieron:

\section{APROBAR}

Acto continuo, el presidente del jurado comunicó al interesado el resultado de la evaluación y, en caso aprobatorio, le fue tomada la protesta. 


\section{Dedicatoria.}

Al poderoso Jesucristo.

A María Guadalupe y Luis Fernando.

A Wendy, Areli y Ricardo.

A Grace.

A mis amigos de Espacio Adolescentes y mi célula.

Al Dr. Alberto Escamilla Cadena. 


\section{Agradecimientos}

En primer lugar quiero agradecer a Dios por permitirme terminar esta maestría y por guiarme en este trayecto.

Deseo mostrar mi gratitud con el Dr. Alberto Escamilla por dirigir esta tesis. También al jurado les quiero agradecerles, a la Dra. Josefina Maldonado y al Dr. David Morales.

Deseo agradecer a la UAM Iztapalapa y al Posgrado de Estudios Sociales en la línea de Procesos Políticos la oportunidad de estudiar la maestría. También quiero agradecer a cada uno de los profesores que me dieron clase.

También es importante reconocer y mencionar a los compañeros y compañeras que cursaron el trayecto de esta maestría conmigo. Sus aportaciones en clase y sus perspectivas enriquecieron mi vida.

Deseo expresar mi gratitud a Conacyt por el apoyo económico brindado para cursar esta maestría.

A los amigos y amigas que son una parte y esencia de mi vida, les doy gracias por la ayuda y respaldo en todo momento. 


\section{Índice}

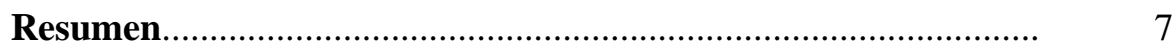

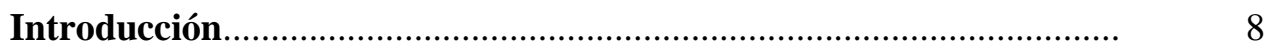

\section{Capítulo 1 Democracia procedimental}

\begin{tabular}{|c|c|}
\hline 1.1 & 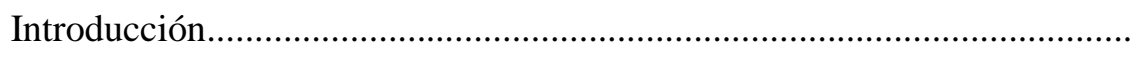 \\
\hline 1.2 & Democracia procedimental.. \\
\hline 1.3 & Estado de derecho......................... \\
\hline 1.4 & 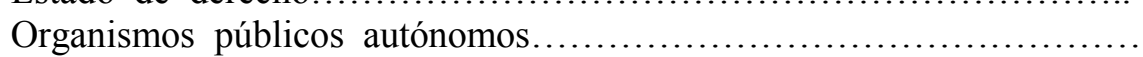 \\
\hline 1.5 & Financiamiento \\
\hline 1.6 & Fiscalización. \\
\hline 1.7 & Legalidad \\
\hline 1.8 & Imparcialidad.. \\
\hline 1.9 & Conclusiones... \\
\hline
\end{tabular}

Capítulo 2 El Consejo General y la Unidad de Fiscalización del IFE: reformas y estructura orgánica

$2.1 \quad$ Introducción ................................................... 63

$2.2 \quad$ Del Comité Federal de Vigilancia al Instituto Federal Electoral......... 64

2.3 El tránsito de las reformas electorales en materia de fiscalización...... 76

$2.4 \quad$ Estructura orgánica del IFE...................................... 84

2.4.1 Partes integrantes del IFE........................................ 84

2.4.2 Consejo General del IFE ....................................... 85

2.4.3 Atribuciones del Consejo General del IFE.......................... 86

2.4.4 Valores rectores del IFE....................................... 88

2.5 Unidad de Fiscalización de los Recursos de los Partidos Políticos....... 89

2.5.1 Proceso de fiscalización de los recursos de los partidos políticos.......... 93

$2.6 \quad$ Conclusiones................................................... 97

Capítulo 3 El principio de imparcialidad en las elecciones presidenciales de 2012

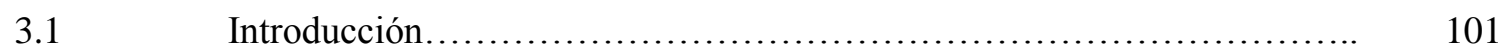

Transición democrática en México................................... 101

3.3 Batallas en torno a la conformación del Consejo General del IFE en 2003,

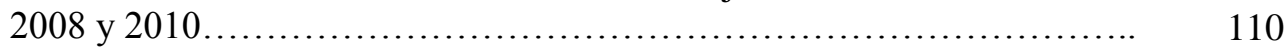

$3.4 \quad$ Caso Monex....................................................... 120

3.5 Valoración del caso Monex por el Consejo General del IFE............... 126

Conclusiones.................................................... 156 
Capítulo 4 El principio de legalidad en las elecciones presidenciales de 2012

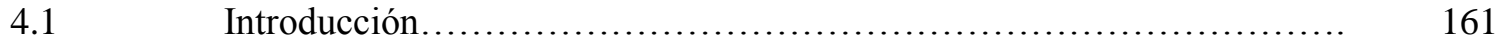

4.2 Legalidad en el contexto electoral mexicano.......................... 162

4.3 Evaluación del caso Monex por el Consejo General del IFE............... 170

$4.4 \quad$ Conclusiones....................................................... 207

Conclusión........................................................ 213

Bibliografía ...................................................... 222 


\title{
Resumen
}

Los organismos autónomos electorales juegan un rol importante en la consolidación de los procesos democráticos en los países. Las decisiones que toman mejoran la democracia. El Instituto Federal Electoral (IFE) en México es el organismo encargado de conducir el rumbo de las elecciones. Otra de sus tareas es la fiscalización de los recursos recibidos por los partidos políticos. Las elecciones presidenciales en materia de fiscalización del año 2012 en México representaron un momento de prueba las facultades del IFE en el rubro de fiscalización. De esta área trata esta tesis.

\begin{abstract}
Autonomous Electoral Organisms play an important role in consolidation on democratic process in countries. This organisms make decisions that make better democracy. Electoral Federal Institute (EFI) in Mexico is the organism responsible for elections. Other his task is regulate the resources obtained for political parties. Presidential elections in 2012 on Mexico in resources topic was a moment of test of the faculties of EFI in this area. About this theme is this thesis.
\end{abstract}




\section{Introducción.}

La democracia es la forma imperante de gobierno en el mundo. Es poco probable que en una sociedad moderna la democracia pudiera funcionar sin recursos. El dinero es parte importante del funcionamiento de la democracia. Sin el dinero los partidos políticos no podrían realizar las funciones que se requieren en una sociedad plural, como es la representación de los ciudadanos. El gasto que representa mantener en movimiento una organización política es alto. Los costos asociados con las campañas electorales, el pago de estructuras partidistas y otros elementos hacen que sean fundamentales los recursos.

El dinero de sujetos y empresas al proceso democrático de forma no establecidas en la ley representa riesgos al proceso democrático. Por tanto, es preciso que haya instituciones que tengan la revisión y control de los recursos que reciben de los partidos políticos. Estas instituciones, son conocidas como organismos autónomos electorales. Entre sus funciones están fiscalizar los fondos de los partidos, además de sancionar conductas que sean contrarias a la normatividad vigente.

En México la creación del Instituto Federal Electoral (IFE) tuvo como objetivo procurar elecciones democráticas. Pero también la meta fue actuar como mecanismo de fiscalización de los partidos políticos. Para este caso fue creada Comisión de Fiscalización de los Recursos de los Partidos Políticos y Agrupaciones Nacionales para posteriormente convertirse en la Unidad de Fiscalización de los Recursos de los Partidos Políticos. Esta Unidad cuenta con autonomía de gestión que le 
permite que su trabajo sea más eficaz. Otro órgano dentro del IFE es el Consejo General. Éste dirige el accionar del IFE. En el Consejo General del IFE se toman las decisiones de mayor relevancia y se deciden las quejas y se realizan resoluciones.

Sin embargo la Unidad de Fiscalización y el Consejo General no han estado a salvo de decisiones polémicas en materia de fiscalización electoral. En la elección presidencial de 2012, se presentó un acontecimiento que generó revuelo en la opinión pública del país. Días antes de realizar la elección en 2012, el candidato a la presidencia del PRD, Andrés Manuel López Obrador presentó a los medios de comunicación tarjetas de débito de la banca Monex que presuntamente fueron utilizadas por el PRI.

Posteriormente representantes del PAN también se unieron a la queja por el pago de estructura electoral con tarjetas Monex durante el periodo de campaña por un monto de 701471800 pesos. El PAN presentó su denuncia ante el IFE el día 26 de junio de 2012. El PAN presentó una queja contra el PRI por el uso de tarjetas de Monex. El IFE recibió la denuncia. La Unidad de Fiscalización tardó 211 días investigando y resolvió que la queja por la ilegalidad del origen del dinero era infundada. Mientras que en las votación del Consejo General del IFE se resolvió revisar la legalidad del contratos, se dio por válido el origen, pero no el destino de los recursos.

La decisión que tomó el Consejo General generó malestar por parte de los partidos de oposición al PRI además que provocó desagrado en una parte de la sociedad mexicana. Por tal motivo, el caso Monex es trascendente estudiarlo. 
Ante tal situación la pregunta que guía esta investigación es la siguiente: ¿se vulneró el principio de legalidad e imparcialidad en las elecciones del 2012 por la sentencia del IFE del caso Monex? La hipótesis que se brinda a esta pregunta es que después de las elecciones presidenciales de 2012, ante la impugnación del PDR y el PAN por el caso Monex, el IFE decidió no castigar al PRI, tergiversando la legalidad e imparcialidad del proceso electoral en materia de recursos.

La decisión de los partidos políticos como el PAN y PRI en disminuir la calidad de las personalidades independientes en la elección de los miembros del Consejo General ha menoscabado la actuación del IFE. También es importante destacar un elemento que deteriora la capacidad en el proceder de la Unidad de Fiscalización es la designación del titular de la Unidad de Fiscalización por el Consejo General. La cobertura de cuotas partidistas en el Consejo General también afecta el nombramiento y actuación de la Unidad.

Se puede decir que se afectó a la imparcialidad y legalidad en la resolución que tomaron los consejeros del Consejo General del IFE cuando su actuación estuvo marcada por omisiones a su labor y a su desempeño en la discusión del caso Monex el día 23 de enero de 2013 que fue una sesión extraordinaria. Por otra parte, un elemento que es menester mencionar es que en la literatura sobre los conceptos de legalidad e imparcialidad no se menciona que estos dos términos pueden desvirtuarse por las omisiones y limitantes en la formación de los aplicadores de la ley.

El objetivo específico que persigue la investigación es analizar el procedimiento de fiscalización del IFE en el caso Monex y su 
resolución. Mientras que como objetivo particulares es indagar cuáles son los razonamientos que proporcionó la Unidad de Fiscalización de los recursos de los partidos políticos del IFE con respecto al caso Monex. Otro de los objetivos que procura esta investigación es analizar los argumentos dados por consejeros electorales del IFE en la resolución del consejo para no sancionar al PRI en el caso Monex.

Para el estudio de las resoluciones del IFE para el caso Monex, la delimitación espacial es México, mientras que la delimitación temporal será el año 2012. El estudio de caso serán las elecciones presidenciales de México en 2012. El metodología será cualitativa y más en específico el método interpretativo por medio del análisis de las sentencias del IFE.

La variable dependiente será el IFE y la variable independiente será la impugnación del PRD y PAN. Los indicadores que se utilizarán será la sentencia del IFE del 23 de enero de 2013. En esta sesión se desahogó los temas principales del caso.

Los capítulos que integran la tesis son cuatro. En el primer capítulo se hace una revisión de los aspectos trascendentes que abarca la democracia procedimental. También se realiza un recuento del concepto de organismos públicos autónomos y del término de financiamiento $\mathrm{y}$ fiscalización, además de las nociones de legalidad e imparcialidad que guiarán el decurso de esta investigación.

En el segundo capítulo se abordará la estructura que conforma al IFE, para el caso de esta tesis serán el Consejo General y la Unidad de Fiscalización. Se estudiarán sus atribuciones legales y su conformación. 
Mientras que el tercer capítulo se verificará si la actuación del Consejo General del IFE con respecto al caso Monex afectó el principio de imparcialidad que debe regir la actuación del instituto. Por último, el cuarto capítulo versará acerca si se vulneró la legalidad en el accionar del Consejo General del IFE respecto al mismo caso. 


\section{Capítulo 1. Democracia procedimental.}

\subsection{Introducción.}

En este primer capítulo se revisarán los conceptos clave que ayudarán a comprender el objeto de estudio de esta tesis la democracia. El término que se analizará será: democracia en la vertiente procedimental. Para esta corriente hay que estudiar los principales autores que son Schumpeter, Dahl, Sartori, Przeworski y Nohlen. Después se estudiarán los organismos públicos autónomos que es una parte relevante del estudio y sus funciones. Leonardo Morlino con su desarrollo teórico acerca de la calidad de la democracia.

Posteriormente del financiamiento, se abordará el concepto de fiscalización. Por último, se estudiarán los términos de legalidad e imparcialidad que serán importantes dentro del desarrollo del estudio. Estos conceptos darán el marco teórico que permitirá enmarcar el caso de estudio de este trabajo.

La pregunta que guiará este capítulo será: ¿cuáles son los principios que debe garantizar una democracia procedimental? 


\section{2.-Democracia procedimental.}

Para comenzar este apartado es preciso mencionar que existen dos grandes concepciones del término de democracia. Una de ellas, es la conocida como la democracia ampliada y la otra democracia minimalista. La primea está representada por un autor norteamericano Robert Dahl mientras que los autores que proponen una democracia minimalista son Sartori y Schumpeter.

La democracia procedimental se desarrollará en este apartado, se revisará también la democracia ampliada. La democracia de este tipo, la procedimental es la forma que más predomina en el mundo. México no es la excepción a este respecto. El núcleo central de la democracia procedimiento como un proceso cuyo eje es el voto. Junto con el derecho al voto por parte de los ciudadanos, están las instituciones electorales que son determinantes en los procesos electorales. Éstas proporcionan los elementos que hacen posible el adecuado funcionamiento de la democracia. Se comenzará a analizar los aspectos que conforman a la democracia procedimental.

La democracia procedimental es "un conjunto de reglas (primarias o fundamentales) que establecen quién está autorizado para tomar las decisiones colectivas y bajo qué procedimientos". ${ }^{1}$ Cuando un grupo toma una decisión política se necesita que haya ciertas reglas que rijan

\footnotetext{
${ }^{1}$ Bobbio, Norberto. El futuro de la democracia, $2^{\circ}$ Ed. en español.FCE. México. 1996. Pág. 24.
} 
la toma de decisiones. Estas normas facultan a determinadas personas que poseen el derecho de tomar decisiones.

La democracia procedimental posee un aspecto relevante que es donde el ciudadano tiene derechos como de la libertad y la igualdad para poder desarrollarse libremente. Estos derechos que los ciudadanos tienen, precisan reglas y procedimientos que regulen las relaciones entre los individuos que conforman la sociedad.

Estas disposiciones buscan proteger los derechos de cada uno de los miembros de este conjunto humano. Las reglas juegan un papel relevante en la democracia procedimental porque generan dinámicas de libre ejercicio de los derechos de los ciudadanos para el desarrollo personal. Además de que se reconoce que existen en la sociedad una amplia diversidad de individuos con características que difieren de otros grupos sociales.

Ligado a las reglas que rigen en una sociedad democrática, está el aspecto en donde el mayor número de miembros que conforman una comunidad tengan la posibilidad de elegir quién decidirá por ellos en el ámbito político. Esto significa que los ciudadanos en una sociedad occidental poseen el derecho de votar por el candidato que más convenga a su punto de vista a un cargo de elección popular. Con la universalización del voto a todos los ciudadanos mayores de 18 años en el mundo, se creó esta condición necesaria. En la democracia priva la regla de la mayoría.

Es decir, cuando se realiza una votación y el voto de una amplia porción de los ciudadanos decide una postura, se considera que es válida 
porque representa una decisión de la mayoría de las personas. Por último, es preciso mencionar que los ciudadanos que eligen a sus representantes políticos deben de contar con ciertas condiciones para llevar a cabo esta tarea. Se requiere que se garantice a cada ciudadano el derecho de libertad de opinión, de expresión, de reunión y asociación.

Pero es preciso hacer una acotación acerca de la democracia. Siguiendo la línea de pensamiento de Luigi Ferrajoli, menciona que cuando solamente se entiende a la democracia como la manera de quién toma las decisiones y con qué procedimientos se toman estas decisiones, "se ignora el paradigma del Estado de derecho, que no admite la existencia de poderes no sujetos a la ley, y todavía más del Estado constitucional de derecho, dentro del cual no es verdadero que el poder del pueblo sea ilimitado", esto quiere decir que aunque la teoría de la democracia menciona el quién y el qué, el Estado de derecho juega un papel fundamental.

\subsection{Estado de derecho.}

La aparición del Estado de derecho se produjo cuando la clase burguesa obtuvo el poder político después de la revolución francesa de 1789. Las libertades políticas, sociales y económicas en las cuáles basaba su existencia se transmitieron al Estado de derecho. Los individuos que

${ }^{2}$ Ferrajoli, Luigi. Principia Juris. Teoría del derecho y la democracia. Editorial Trotta. Madrid. 2011. Pág.10. 
conforman la sociedad poseen una voluntad general que los hizo libres de obedecer a otros actores que no fueran su propio razonamiento.

Los representantes políticos que se eligieran a los cargos de representación popular tenían que responder a la voluntad general de la comunidad. Estrechamente ligado a este aspecto, la división de poderes buscaba limitar el poder de los monarcas para preservar las libertades individuales.

La segmentación del poder político permite que se garanticen las prerrogativas propicias para que los individuos tengan un adecuado desarrollo. La vía adecuada que requiere la actuación los representantes políticos es que se guíen de acuerdo a los normas que se hayan establecido en una sociedad. Esto es, que el accionar de los funcionarios públicos debe estar conforme al derecho o dicho de otra manera es menester que haya legalidad. El aspecto de la legalidad se tratará en un apartado más adelante.

Es importante destacar que por Estado constitucional de derecho se entiende "la constitución no sólo disciplina las formas de producción legislativa sino que impone a ésta prohibiciones y obligaciones de contenido, correlativas unas a los derechos de libertad y las otras a los derechos sociales" "y en dónde la democracia constitucional "se caracteriza por la sujeción al derecho de los poderes supremos". 4

\footnotetext{
${ }^{3}$ Ferrajoli, Luigi. "Pasado y futuro del Estado de derecho". En Carbonell, Miguel Wistano Orozco (Coord.) Estado de derecho. Conceptos, fundamentos y democratización en América Latina. $1^{\circ}$ Edición. UNAM-ITAM-Siglo XXI Editores. México. 2002.Pág.192

${ }^{4}$ Ferrajoli, Luigi.Principia Juris. Teoría del derecho y la democracia. Editorial Trotta. Madrid. 2011. Pág.76.
} 
El Estado de derecho posee una característica que es que "la sujeción a la ley de todos los poderes, no sólo los públicos sino también los privados, y a su limitación y regulación para la tutela de todos los derechos fundamentales en todas las relaciones sociales". 5 Según Ferrajoli el Estado de derecho procura dos aspectos fundamentales que son: minimizar el poder y la violencia. También es trascedente remarcar que todas las actividades estatales que se realizan dentro del Estado de derecho "se pueden reducir a un previo funcionamiento calculable, según normas fijadas de antemano". 6

Cuando se habla de Estado de derecho, se debe de tener en cuenta a la forma en que se plasma la ley, esto es la constitución política de una nación. Sartori menciona que la constitución ayuda a la toma de decisiones políticas. En otras palabras "estructuran y disciplinan los procesos de toma de decisiones de los Estados."7

Ligado con este aspecto está el hecho que la interacción que se lleva a cabo entre los ciudadanos y sus representantes es preciso que se desarrolle en las capacidades de control de las acciones del delegado al cargo público. Es decir que los ciudadanos ejerzan un efectivo contrapeso al poder. Mientras se presente este hecho, los ciudadanos podrán ejercer sus derechos sin interferencia de terceros.

La democracia entendida como un procedimiento hace preciso señalar que "las elecciones representan el método democrático para designar a

\footnotetext{
${ }^{5}$ Ferrajoli, Luigi. Ibíd. Pág.223.

${ }^{6}$ Schmitt, Karl. Teoría de la constitución. Alianza Editorial. España. 1982. Pág. 142.

${ }^{7}$ Sartori, Giovanni. Ingeniería constitucional comparada. $2^{\circ}$ Reimpresión. FCE. México. 1996. Pág. 217.
} 
los representantes del pueblo". ${ }^{8}$ Más en específico, Nohlen refiere que es una técnica para la selección de representantes que conforman la base de la democracia liberal. Para que exista una elección democrática por lo menos debe haber dos o más posibilidades para elegir. Las elecciones realizan ciertas funciones que es importante destacar: a) expresa la confianza del electorado en los candidatos electos; b) constituir cuerpos representativos funcionales y c)controlar el gobierno. ${ }^{9}$

Para que se realice un proceso democrático es menester que se cumplan ciertas condiciones además de las ya mencionadas en la parte de arriba. Robert Dahl precisa que los ciudadanos requieren que exista una participación efectiva, una igualdad de votos en la etapa decisoria, compresión esclarecida. ${ }^{10}$

El primer punto hace referencia a la toma de decisiones, los ciudadanos deben contar con las oportunidades apropiadas y equitativas para hacer manifiesta sus preferencias. El segundo aspecto consiste en que a los ciudadanos se les tienen que garantizar una igualdad de oportunidades para decidir y esa decisión será igual a la que tomen los demás miembros del grupo. El tercer punto es que los ciudadanos precisan que se les informe de manera adecuada sobre los asunto públicos y que exista debates acerca de los mismos para realizar una decisión más adecuada.

Es importante destacar que la democracia representativa cumple la función de permitir que el ejercicio del poder se distribuya de forma adecuada. El siguiente párrafo indica de manera precisa el papel que

\footnotetext{
${ }^{8}$ Nohlen, Dieter. Sistemas electorales y partidos políticos. $1^{\circ}$ Ed. FCE-UNAM. México. 1994. Pág. 9. ${ }^{9}$ Nohlen, Dieter. Ibíd. Pág. 15.

${ }^{10}$ Dahl, Robert. La democracia y sus críticos. $2^{\circ}$ Ed. Ediciones Paidós. España. 1993. Pp. 135 y 137.
} 
juega la democracia, "la función de la democracia es redistribuir el poder para garantizar a los individuos el ejercicio de sus derechos". ${ }^{11}$.Esto es que la separación de poderes del Estado "limite al poder en beneficio del pueblo y se propicie una atmósfera favorable a la libertad". ${ }^{12}$

También la democracia representativa que se expresa en un voto cumple otra función, y es la "del sustento primigenio de todo entramado constitucional del Estado" ${ }^{13}$ Esto es debido a que el ejercicio de la soberanía popular se lleva a cabo por medio de los órganos del Estado que hacen las leyes.

Además, por medio de la división de poderes la democracia busca que los derechos que poseen los ciudadanos se puedan llevar a cabo. Las garantías individuales se encuentran detrás de todo el entramado institucional y político que subyace en la democracia. Por lo tanto, la democracia pretende lograr que el ejercicio de las prerrogativas y deberes que cuentan los ciudadanos se hagan efectivos. Los derechos que posee el individuo frente al Estado, hacen que el Estado no deba de actuar más allá de los mismos.

Las teorías de la democracia procedimental se desarrollaron ampliamente en el siglo XX. A comparación de los libros que estudiaron el tema de la democracia antes del siglo $\mathrm{XX}$, diversos autores trataron

\footnotetext{
${ }^{11}$ OEA. Nuestra democracia. $1^{\circ}$ Ed. OEA-PNUD-IFE-FCE-Gobierno de España-AECIE México. 2010.Pág. 29.

${ }^{12}$ Patiño Camarena, Javier. Derecho electoral mexicano. $3^{\circ}$ Ed. Editorial Constitucionalista. México. 1996. Pág. 14.

${ }^{13}$ Andrade Sánchez, Eduardo. Derecho constitucional. Oxford University Press. México. 2008. Pág.131.
} 
de hacer observables y medible los aspectos que conforman la democracia en los países de Occidente. Por tanto, es preciso revisar los principales autores que propiciaron el fortalecimiento de esta teoría.

En esta parte de la democracia procedimental, es importante destacar un autor que proporciona una visión realista de la democracia fue el economista austríaco Joseph Schumpeter. Este economista realizó una serie de aportaciones a la teoría de la democracia que es importante destacar. Schumpeter hizo un análisis económico de la política. El comparó a los votantes con los compradores que se mueven en el mercado, y a los políticos que participan en las elecciones como mercaderes que venden un producto.

La definición que proporciona Joseph Schumpeter de democracia es la siguiente "el método democrático es un sistema institucional, para la toma de decisiones políticas, en la cual el individuo adquiere el poder de decidir mediante una lucha competitiva por los votos del elector". ${ }^{14}$

Esta posición que tomó Schumpeter fue diferente de las definiciones clásicas de la democracia porque este autor menciona que la democracia es sólo un proceso para la toma de decisiones. Ya no es un fin en sí la democracia, sino un procedimiento dónde los ciudadanos deciden si quieren que los gobierne uno de los diversos grupos que se presentan en la contienda electoral.

Las características básicas que precisan tener las democracias dentro de la concepción de Schumpeter son: la libre competencia política de las personas que tratan de ganar los votos de los electores y una segunda

\footnotetext{
${ }^{14}$ Schumpeter, Joseph. Capitalismo, socialismo e democracia. Editora Fundo de Cultura. Brasil. 1961. Pág.
} 328. 
condición necesaria es la oportunidad de escoger que tienen los ciudadanos quién quiere que los gobierne.

Esta definición proporcionada anteriormente está asociada con algunos aspectos que son importantes destacar. El primero punto es que el votante escoge "quien será su líder". ${ }^{15}$ Solamente le compete al elector el poder rechazar o aceptar los líderes que se presentan en las elecciones presidenciales o estatales.

Estrechamente ligado a este aspecto está el hecho que una vez que los electores han hecho la elección de los representantes en los cargos de la administración pública, Schumpeter llama a los ciudadanos a adoptar su rol en la división del trabajo. Esto es, "que una vez habiendo elegido a un ciudadano, la acción política pasa a ser de él [candidato] y no suya". ${ }^{16} \mathrm{El}$ elector pasa a asumir un papel de dejar que su representante político se haga cargo de sus asuntos y que ya no reciba órdenes del ciudadano.

Schumpeter hace una crítica a la noción de bien común y a la de voluntad general porque dice que no existe un único medio para representar las voluntades individuales. Sino que hay diversas voluntades que desean ser tomadas en cuenta y por lo tanto existe el problema para cómo unificar esas voluntades a fin de que sea una sola.

\footnotetext{
${ }^{15}$ Schumpeter, Joseph. Ibíd. Pág. 333.

${ }^{16}$ Schumpeter, Joseph. Opus Cit. Pág. 358.
} 
Comparado con el votante en la política "el elector, a diferencia del consumidor en el mercado, es visto como un ente guiado por sus impulsos y su instinto de rebaño". ${ }^{17}$

Esta postura es diferente, ya que esta postura que propone Schumpeter rechaza la posición de que el ciudadano es racional, sino contrariamente son sus sentimientos los que lo guían. Los electores que participaban en las elección de candidatos a cargos de representación popular poseen poca capacidad para decidir qué grupo político en la cumbre desea que le gobierne. Esta visión del ciudadano no toma en cuenta que el ciudadano sí tiene la capacidad de elegir de forma racional.

Cuando los ciudadanos votan por los candidatos a cargos de representación popular, estos políticos, desde la perspectiva de Schumpeter, solamente luchan por obtener el poder y no por opciones estratégicas o políticas públicas diferentes.

La situación que está en pugna es el acceso al poder. Podría parecer que Joseph Schumpeter propone la pelea por acceder a los cargos políticos sin tener en cuenta las reglas, pero no es así sino que propone que el "régimen democrático es un método de competencia política" ${ }^{\prime 18}$ donde las reglas que deben respetar los partidos políticos son las de la competencia electoral.

Los partidos políticos que pierden elecciones poseen la certeza de que en las próximas elecciones podrán ganar y llegar al poder. La

\footnotetext{
${ }^{17}$ Vidal de la Rosa, Godofredo. Desigualdad social y equidad política. Ensayos críticos de teoría democrática. $1^{\circ}$ Ed. UAM Azcapozalco y Miguel Ángel Porrúa. México.2012. Pág. 35

${ }^{18}$ Vidal de la Rosa, Godofredo. Ibíd. Pág. 42.
} 
competencia en las elecciones entre los partidos políticos lleva a que haya alternancia en el poder, sí es que ganan la contienda electoral. Las elecciones para escoger candidatos a la administración pública permiten que exista un calendario electoral en donde una institución electoral se haga cargo de la organización de las mismas, o en otros casos que diversas instituciones se fortalezcan en sus funciones políticas.

La propuesta que realizó Joseph Schumpeter de la democracia, fue desarrollada con la reflexión que hizo Robert Dahl sobre la misma. Dahl, a diferencia de Schumpeter, menciona que la democracia precisa de una base social para que pueda funcionar de una mejor manera.

No solamente es que las élites tengan acceso a los puestos de representación popular por medio de elecciones periódicas sino que el acceso y control de los recursos sea distribuida entre diversos sectores para que exista un sustento más propicio para el régimen democrático.

El poder político no debe ser monopolizado por un grupo oligárquico sino que es menester que haya una pluralidad de elementos que compartan el poder. Esto se llamaría el pluralismo democrático. Para Dahl es preciso que ninguno de los grupos de poder detenten el poder por si solos, sino que sea compartido con otros grupos.

El elemento que subyace en la teoría de la poliarquía de Robert Dahl acerca de la democracia es que a medida de que se van dando las condiciones sociales y políticas que requieren una sociedad moderna se está más cerca del ideal democrático.

Cuando los diversos grupos tienen idénticas posibilidades de ser elegidos para representar a los ciudadanos en la administración pública y 
uno de ellos gana, se genera un proceso de eliminación gradual de la desigualdad de acceso al poder y a los recursos que son necesarios para arribar al mismo y mantenerse. Este proceso lleva a que se procure una equidad.

La democracia representativa debe cumplir una serie de condiciones para que pueda ser llamada como tal. Según el politólogo estadounidense Robert Dahl, la democracia representativa debe de cumplir todas las condiciones que se enumerarán en el cuadro 1.

Cada uno de los requisitos que precisa la democracia representativa y que son presentados en el cuadro 1, muestran las distintas libertades y derechos que deberían gozar los ciudadanos en este tipo de democracia. El sufragio universal es la base del derecho que poseen los ciudadanos para elegir a sus representantes. 
1.-Cuadro. Requisitos para el establecimiento de la democracia.

\begin{tabular}{|c|c|}
\hline Para tener oportunidad de: & Se requieren las siguientes garantías institucionales: \\
\hline \multirow[t]{5}{*}{ I.-Formular preferencias } & 1.-Libertad de asociación. \\
\hline & 2.-Libertad de expresión. \\
\hline & 3.-Libertad de voto. \\
\hline & $\begin{array}{l}\text { 4.-Libertad para que los líderes políticos compitan en } \\
\text { busca de apoyo. }\end{array}$ \\
\hline & 5.-Diversidad de fuentes de información. \\
\hline \multirow[t]{7}{*}{ II.- Manifestar preferencias } & 1.-Libertad de asociación. \\
\hline & 2.-Libertad de expresión. \\
\hline & 3.-Libertad de voto. \\
\hline & 4.-Elegibilidad para la cosa pública. \\
\hline & $\begin{array}{l}\text { 5.-Derecho de los líderes políticos a competir en } \\
\text { busca de apoyo. }\end{array}$ \\
\hline & 6.-Diversidad de fuentes de información. \\
\hline & 7.-Elecciones libres e imparciales. \\
\hline \multirow[t]{8}{*}{$\begin{array}{l}\text { III.-Recibir igualdad de trato por parte del gobierno } \\
\text { en la ponderación de las preferencias. }\end{array}$} & 1.-Libertad de asociación. \\
\hline & 2.-Libertad de expresión. \\
\hline & 3.-Libertad de voto \\
\hline & 4.-Elegibilidad para el servicio público \\
\hline & 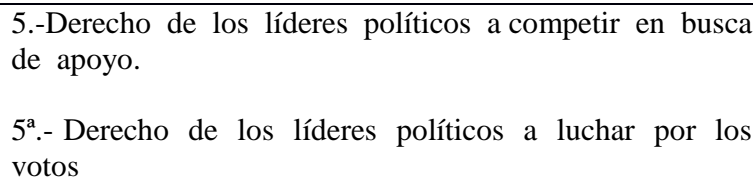 \\
\hline & 6.-Diversidad de fuentes de información. \\
\hline & 7.-Elecciones libres e imparciales. \\
\hline & $\begin{array}{l}\text { 8.-Instituciones que garanticen que la política del } \\
\text { gobierno dependa de los votos y demás formas de } \\
\text { expresar las preferencias. }\end{array}$ \\
\hline
\end{tabular}

Fuente: Tomado de Robert Dahl. La poliarquía. Editorial Tecnos. España. 1989. Pág. 15. 
La materialización de la práctica del voto en las elecciones políticas es un hecho constante que sucede en las democracias representativas. Es trascendente recalcar que la participación de un porcentaje más elevado de ciudadanos que votan en las elecciones hace que la capacidad de representación en los regímenes políticos actuales deba dar lugar al derecho a participar y a que exista el debate público.

Estas dos condiciones que es menester que cumpla un régimen democrático, están ligados al término que Robert Dahl propuso, que es la poliarquía. Las poliarquías son "regímenes relativamente (pero no completamente) democráticos; o, dicho de otra forma, las poliarquías son sistemas sustancialmente liberalizados y popularizados, es decir, muy representativos a la vez que francamente abiertos al debate público". ${ }^{19} \mathrm{El}$ término de poliarquía lo desarrolló de forma más explícita en otro texto suyo. Dahl en su libro La democracia. Una guía para los ciudadanos dice que:

poliarquía se deriva de las palabras griegas que significan "muchos" y "gobierno"; se distingue así "el gobierno de los muchos" del gobierno de uno o monarquía, o del gobierno de los pocos, aristocracia u oligarquía. A pesar de que dicho término apenas había sido usado, un colega y yo lo introdujimos en 1953 como una forma adecuada para referirnos a una democracia representativa moderna con sufragio universal. ${ }^{20}$

Siguiendo la línea de argumentación brindada por Robert Dahl se puede decir que la poliarquía es “ $[u n]$ gobierno democrático a escala del Estado-nación o país". ${ }^{21}$ Los mecanismos que requiere una

\footnotetext{
${ }^{19}$ Dahl, Robert. La poliarquía. Editorial Tecnos. España. 1989. Pág. 18.

${ }^{20}$ Dahl, Robert. La democracia. Una guía para los ciudadanos. Taurus-Alfaguara. España. 1999. Pág. 105.

${ }^{21}$ Dahl,Robert. Ibíd. Pág. 107.
} 
democracia del tipo poliarquía son: a)cargos públicos electos; b) elecciones libres, imparciales y frecuentes; c) libertad de expresión; d) fuentes alternativas de información; e) autonomía de las asociaciones y f)ciudadanía inclusiva. ${ }^{22}$

El aspecto que busca destacar esta propuesta teórica de Dahl difiere de otras debido a que pretende establecer que "la teoría de la poliarquía no se enfoca primordialmente en los requisitos constitucionales, sino en los requisitos sociales para un orden democrático",23.

Comentando la teoría de Robert Dahl sobre la poliarquía, Giovanni Sartori menciona que la poliarquía contiene tres elementos que son esencialmente constitutivos de la misma: "la democracia a gran escala es un procedimiento y un mecanismo que: a) genera una poliarquía abierta cuya concurrencia en el mercado electoral b)atribuye el poder al pueblo y c)específicamente hace valer la responsabilidad de los líderes para con los liderados". ${ }^{24}$ Esta definición que presenta Sartori de la teoría de la poliarquía también tomó elementos de la propuesta teórica de Joseph Schumpeter para hacer más completa la explicación de la democracia procedimental.

En la democracia procedimental, los representantes son elegidos por los ciudadanos para tomar las decisiones de la nación en su conjunto. El representante debe encontrar "la desvinculación del representante de la nación del individuo y de sus intereses particulares". ${ }^{25}$ Por lo que se deduce que en la democracia representativa, los representantes del

\footnotetext{
${ }^{22}$ Dahl, Robert. Opus Cit. Pág. 99.

${ }^{23}$ Dahl, Robert. Un prefacio a la teoría de la democracia. Ediciones Gernika. México. 1987. Pág. 108.

${ }^{24}$ Sartori, Giovanni. Teoría de la democracia. El debate contemporáneo. $3^{\text {o }}$ Reimpresión. Tomo I. Alianza Editorial. España. 2001. Pág. 202.

${ }^{25}$ Bobbio, Norberto. Liberalismo y democracia. $11^{\text {a }}$ Reimpresión. FCE. México. Pág. 38
} 
pueblo no deben de estar sujetos a un mandato imperativo sino a visión del conjunto de la sociedad.

Aunque este tipo ideal de visualizar la representación es eso solamente un modelo, la crítica que se le hace es que en la práctica cotidiana de las cámaras representativas los intereses partidistas son los que en una porción mayoritaria de veces prevalecen sobre los intereses de la sociedad en su conjunto. ${ }^{26}$

La democracia procedimental también está basada en el conjunto de reglas y normas que rigen la disputa por el poder político dentro de una sociedad democrática. Para este modelo, la democracia es un conjunto de reglas que los actores políticos respetan para poder resolver sus diferencias y evitar que se rompa el acuerdo de no agresión.

De manera diferente a cómo se entendía anteriormente a la democracia como el poder del pueblo, Sartori menciona que más que establecer “ [todo el poder al pueblo] se debe transformar, poco a poco, en el principio [todo el poder a ninguno]". ${ }^{27}$ Los elementos que contiene la democracia procedimental son que los actores se organizan de manera colectiva para lograr sus intereses colectivos.

Los partidos políticos son de suma importancia los partidos políticos en la democracia procedimental porque son el intermediario entre los ciudadanos y el Estado. Los partidos políticos son estructuras políticas que utilizan los ciudadanos para hacer valer sus metas. Estas instituciones representan las demandas de los ciudadanos.

\footnotetext{
${ }^{26}$ Véase. Bobbio, Norberto. El futuro de la democracia. $2^{\mathrm{a}}$ Reimpresión en español. FCE. México. 1996.Pág. 58.

${ }^{27}$ Sartori, Giovanni. ¿Qué es la democracia?2ª Reimpresión. Taurus. México. 2005. Pág. 88.
} 
Los individuos delegan a estas instancias la presencia de sus intereses, proyectos y opiniones. Las estructuras institucionales dentro de las que se desenvuelven la democracia son importantes. Debido a que los grupos políticos que participan en las elecciones que se realizan en un país democrático dependen de recursos económicos, humanos que alguna veces son desiguales.

La instancia partidista que dispone de más dinero y recursos es la que tiene más posibilidades de ganar elecciones. Esta disparidad de medios de que disponen los partidos políticos se puede atenuar si las instituciones que regulan el proceso electoral "son neutras en relación a las identidades de los participantes". ${ }^{28}$

Las organizaciones que detentan la facultad de aplicar las reglas que rigen la competencia entre los diversos partidos políticos que procuran el poder son de suma trascendencia para la democracia. Estas instituciones, como las instituciones electorales, son las que generan la solución de los conflictos que se pudiesen presentar entre los diversos partidos políticos y que no degenere en un problema más allá de las organizaciones estatales y provoque un desequilibrio social. Este hecho se conoce como democracia consolidada.

Adam Przeworski menciona que "cuando la adhesión -actuar de conformidad con la estructura institucional- constituye el estado de equilibrio de las estrategias descentralizadas de todas las fuerzas políticas relevantes". ${ }^{29}$ Es cuando se posee una democracia consolidada.

\footnotetext{
${ }^{28}$ Przeworski,Adam. Democracia e mercado. No leste Europeu e na América Latina. Dumará Distribuidora de Publicaciones. Brasil. 1994. Pág. 26.

${ }^{29}$ Przeworski, Adam. Ibíd. Pág. 46.
} 
Antes de poder arribar a una democracia consolidada diversas naciones que no tenían regímenes democráticos tuvieron que pasar por una transición a la democracia. Según Przeworski la transición a la democracia debe de incluir a las instituciones que den cauce a la lucha por el poder político. Es necesario tener en cuenta que las instituciones que se requieren para que se dé un paso de un régimen político autoritario a uno democrático son las organizaciones públicas autónomas que forma parte del Estado. ${ }^{30}$

Para la mayoría de los países latinoamericanos la transición a la democracia fue un proceso que tuvo sus avances y retrocesos. Samuel Huntington explica el proceso de la ampliación de la democracia en diversas regiones del mundo por su concepto de "ola democrática".

Una ola democrática es "un conjunto de transiciones de un régimen no democrático a otro democrático, que ocurren en un determinado período de tiempo y que superan significativamente a las transiciones en dirección opuesta durante ese mismo período". ${ }^{31}$ Huntington clasifica las olas en tres períodos: la primera ola de democratización 1828 a 1926, la segunda de 1943 a 1962 y la tercera de $1974 .^{32}$

Las transformaciones que experimentaron los regímenes políticos de los países latinoamericanos fueron un proceso en algunos casos gradual que fue de la hegemonía hasta la poliarquía de la que habla Robert Dahl. Al igual que sus pares de latinoamericanos, México no fue la excepción de sumarse a la tercera ola de democratización.

\footnotetext{
${ }^{30}$ Ackerman, John. "Autoridad descentralizada y desarrollo político: la dinámica institucional de la rendición de cuentas". En Isunza, Ernesto y Alberto Olvera (coord.)Democratización, rendición de cuentas y sociedad civil. CIESAS-Miguel Ángel Porrúa. México. 2010. Pág. 294.

${ }^{31}$ Huntington, Samuel. La tercera ola. $1^{\circ}$ Ed. Ediciones Paidós. España. 1994. Pág. 26.

${ }^{32}$ Ídem.
} 
La transformación que experimentó el régimen político mexicano se puede explicar con las teoría de Dahl que dice que "una hegemonía cerrada aumenta las oportunidades de debate público y, por tanto, la transformación en una oligarquía competitiva" y esta fase lleva a "la oligarquía competitiva se transforma entonces en una poliarquía, al aumentar la capacidad de representación del régimen". 33 En el siguiente apartado se hablará de los organismos autónomos electorales.

\section{4.-Organismos Autónomos Electorales.}

Como se pudo notar en el apartado anterior, el desarrollo de las características de una democracia está conectado con la creación de instituciones autónomas electorales. Estos organismos juegan un papel trascendente en la organización de elecciones porque están separadas del área de influencia directa de los otros poderes políticos.

Por tanto estas instituciones son elementos importantes para el adecuado desarrollo de un proceso democrático. El Instituto Federal Electoral (IFE) es un organismo autónomo electoral. Como parte de esta investigación es el accionar del IFE, es preciso saber qué características poseen los organismos autónomos electorales y algunos aspectos relacionados con su área de acción.

\footnotetext{
${ }^{33}$ Dahl, Robert. La poliarquía. Editorial Tecnos. España. 1989. Pág. 41.
} 
Las modificaciones acaecidas en el Estado en la década de 1980, cuando el Estado dejó de tener un rol esencial en la economía, generaron una serie de reformas a las instituciones del Estado para adecuarlo a las nuevas características que exigía la economía neoliberal a nivel mundial. La creación de instituciones autónomas que regularan el accionar del Estado fue una consecuencia de este cambio.

Las normas y reglamentos que estos entes hacen, harían que los mercados funcionaran de mejor manera. Esto también se aplicaba al ámbito político. Estas agencias procurarían ser autónomas e independientes para regular adecuadamente el campo de acción al que son asignadas.

El diseño institucional que posee una institución encargada de la regulación de los procesos, es importante. El problema que se presenta al diseñar estos organismos es proporcionarles "la suficiente autonomía y flexibilidad para realizar sus funciones, pero al mismos tiempo sean capaces de desarrollar los mecanismos institucionales que promuevan la responsabilidad y rendición de cuentas para los ciudadanos y los sectores regulados." ${ }^{34}$

Por regulación se entiende "el mecanismo de control ejercido por una agencia pública con el mandato legal y formal en aquellas actividades que la sociedad considera que debieran ser reguladas". ${ }^{35}$

\footnotetext{
${ }^{34}$ Culebro Moreno, Jorge. "Reforma administrativa y nuevas reformas de organización. El diseño e implementación de organismos reguladores de mercado". En Culebro Moreno, Jorge. (Editor) Nuevas fronteras de la regulación. Transformación y diseño institucional. UAM-C y Juan Pablos Editor. México. 2009. Pp. 19-20.

${ }^{35}$ Culebro Moreno, Jorge. Ibíd. Pág. 23.
} 
Es preciso que los organismos autónomos electorales tengan un alto nivel de especialización en el área. La puesta en marcha de conocimientos técnicos permite que se reduzcan las incertidumbres que se generan en el campo. Las características que poseen estas instituciones son tres: a)un alto nivel de despolitización; b)cierto grado de autonomía y c)procedimiento de toma de decisiones basado en el expertise técnico y el conocimiento. ${ }^{36}$

Los organismos públicos autónomos como pueden ser las instituciones electorales son parte esencial de la democracia. Por organismos electorales se entiende "la autoridad suprema de aquella parte separada, especializada y autónoma del resto del aparato estatal, encargada de la llamada función electoral". ${ }^{37}$ Los organismos electorales autónomos, como su nombre lo indica, son independientes de los otros poderes que configuran la vida política de una sociedad.

Estas instituciones tienen como finalidad que los servidores públicos rindan cuentas de sus actos de la administración de la cual forman parte. Este hecho está ligado a la democracia procedimental, en el sentido de que los votantes en cada elección llaman a cuentas a sus representantes políticos.

Los organismos autónomos electorales han desempeñado un papel trascendente en la consolidación de la democracia de los países occidentales. Un ejemplo de organismos público autónomo en el caso de México ha sido el Instituto Federal Electoral (IFE). El IFE desde su

\footnotetext{
${ }^{36}$ Culebro Moreno, Jorge. Opus Cit. Pág. 31.

${ }^{37}$ Citado en Emmerich, Gustavo Ernesto. "Los organismos electorales locales: panorama, contribución a la democracia y perspectivas". En López Montiel, Gustavo (Coord.)Los procesos electorales desde la perspectiva local. $1^{\circ}$ Edición. Colección Sinergia. IEDF. México. 2009. Pág. 21.
} 
creación en 1990, ha sido un elemento importante de la transición a la democracia en México.

Según la normatividad vigente en el país el IFE es la institución encargada de realizar las elecciones presidenciales y de diputados $y$ senadores, además del conteo de votos, entre otras atribuciones. Los valores que rigen al IFE son: certeza, legalidad, imparcialidad, independencia y objetividad. Dos valores (imparcialidad y legalidad) de la institución serán medidos en este trabajo para la acción del Consejo General en el caso de Monex.

Los organismos autónomos electorales, como es el caso del IFE, también tienen un papel importante en la rendición de cuentas de los partidos políticos. John Ackerman proporciona tres elementos que hacen difícil que la rendición de cuentas sea posible realizarla.

El primer elemento es que los ciudadanos no poseen el adecuado acceso a la información para pedir a sus representantes la rendición de cuentas por sus actos u omisiones. El segundo aspecto hace referencia a la falta de información que hace posible la rendición de cuentas o la participación directa de los ciudadanos en las tareas gubernamentales. Por último, la tercera característica es que al limitarse los mecanismos de rendición de cuentas desde afuera del gobierno, es decir, que el control del gobierno sea después de que ocurrieron sus acciones y no antes. $^{38}$

\footnotetext{
${ }^{38}$ Ackerman. John. Estructura institucional para la rendición de cuentas: Lecciones internacionales y reforma futuras. Auditoria Superior de la Federación-Cámara de Diputados. Serie cultura de la rendición de cuentas. Libro 9. México. 2006. Pág. 13.
} 
Aunque en la democracia la elección de los representantes populares es una herramienta que cumple múltiples funciones, tiene objetivos específicos y uno de ellos es la rendición de cuentas. En la práctica, la rendición de cuentas no es un hecho consolidado en México. La rendición de cuentas es "una acción subsidiaria de una responsabilidad previa, implica una relación transitiva y atañe a la manera en que se dio cumplimiento a esa responsabilidad". 39 Ahora se revisarán los mecanismos que existen en materia de rendición de cuentas.

Los mecanismos de rendición de cuentas pueden dividirse en cuatro ámbitos: a)reformas weberianas; b)mercantilización; c)rendición de cuentas social y d)organismos autónomos. ${ }^{40}$

El primer caso que es el de reformas weberianas es aquel donde la rendición de cuentas se realiza de manera que el funcionario público rinde cuenta solamente a sus superiores de sus hechos. La segunda forma de rendición de cuentas que es la mercantilización hace referencia a los procesos de privatización de los servicios públicos en donde la sociedad es vista como consumidores que castigan o premian a los funcionarios públicos. Las entidades públicas según esta perspectiva se deben de dirigir como si fueran empresas privadas que se rigen por la lógica de competitividad, desregulación y flexibilidad de los mercados laborales.

\footnotetext{
${ }^{39}$ López Ayllón Sergio y Mauricio Merino. "La rendición de cuentas en México: perspectivas y retos". En López Ayllón Sergio y Mauricio Merino (Coord.) La estructura de la rendición de cuentas en México. [en línea]. IIJ. México. 2010.Pág. 1. Formato html, Disponible en Internet: http://www.bibliojuridica.org/libros/libro.htm?1=2800

${ }^{40}$ Ackerman, John. Ibíd. Pág. 15.
} 
La rendición de cuentas social procura que la sociedad tome parte activa en el Estado y por medio de este involucramiento de la ciudadanía en los asuntos públicos sean empoderados los derechos de los ciudadanos.

A través de los servicios públicos brindados por el Estado se busca incluir a los sectores que han sido marginados de sus derechos. La participación de los ciudadanos y las ONG en la rendición de cuentas social es precisa aunque con diversas limitantes. Por último, los organismos autónomos buscan fortalecer la gobernabilidad y el Estado de derecho. Además que estos organismos procuran que exista una rendición de cuentas apropiada y permitir que haya una estrecha relación entre los ciudadanos y el Estado.

Los organismos autónomos del Estado se dividen en prestación de servicios públicos, en regulación del mercado, de fiscalización, de combate a la corrupción y el Ombudsman. Para el caso de la presente investigación se basará en los organismos autónomos de calificación de elecciones y fiscalización.

Por tal motivo, los organismos autónomos electorales procuran que se haga realidad la rendición de cuentas que no solamente se realiza por medio de las elecciones. Los organismos electorales son los que a continuación se profundizarán.

Entre las características que se pueden encontrar en los organismos electorales son un complejo institucional que actúa con independencia de los tres poderes (ejecutivo, legislativo y judicial). La forma en cómo se estructura los organismos electorales es un diseño piramidal en 
dónde las distintas dependencias están subordinadas a la cima en donde se encuentra los altos cargos. Aunque existen organismos autónomos que están formados de manera descentralizada.

Es importante mencionar que las autoridades electorales se pueden dividir en dos tipos: a)administrativa y b)organizativa. La primera hace referencia a la de carácter administrativa tiene como características preparar y dirigir antes, durante y después las elecciones en todas sus fases que también incluye la impartición de justicia. Mientras que cuando se hace referencia a las autoridades de carácter organizativa, éstas se refieren a las:

actividades o funciones que despliega esa estructura o conjunto de órganos o conjunto de órganos, específicamente aquéllas relacionadas con la formación y actualización permanente del registro o censo de electores, realización de las tareas necesarias para llevar a cabo votaciones, el escrutinio, el conteo electoral, la determinación de los candidatos, elegidos y su proclamación. ${ }^{41}$

A diferencia de los primeros, las autoridades organizativas no poseen la facultad de impartir justicia dado el caso que haya presentación de protesta.

Ligado al concepto de organismos autónomos electorales, está el término de órganos constitucionales autónomos que son "aquellos que se establecen en la constitución y que no se adscriben con precisión a ninguno de los poderes tradicionales del Estado". ${ }^{42}$ La definición

\footnotetext{
${ }^{41}$ Citado en Emmerich, Gustavo Ernesto. "Los organismos electorales locales: panorama, contribución a la democracia y perspectivas". En López Montiel, Gustavo (Coord.)Los procesos electorales desde la perspectiva local. $1^{\circ}$ Ed. Colección Sinergia. IEDF. México. 2009. Pág. 22.

${ }^{42}$ Hernández, María del Pilar. "Autonomía de los órganos electorales". Revista Reforma Judicial. México. No. 1. Año 2003. Pág. 81.
} 
anteriormente dada de órganos constitucionales autónomos está dentro de la teoría de la división de poderes y el equilibrio que debe de prevalecer entre ellos.

Estas organizaciones públicas autónomas deben de cumplir ciertas funciones que son necesarias para el proceso adecuados de la democracia. Una de sus funciones es mejorar el desempeño del gobierno en turno así como en la rendición de cuentas que tienen que realizar las instituciones políticas.

Las organizaciones públicas autónomas requieren de ciertas características para que funcionen de una forma adecuada. Necesitan capacidades legales "para que 'tenga[n] garra' y pueda externar su autoridad (por ejemplo, mediante la realización de investigaciones y la aplicación de sanciones), pero también requiere de una estructura institucional que potencie a los agentes proactivos que laboran a favor de reformas, como a profesionales dentro de la misma agencia."

La función que es preciso que posean las organizaciones independientes es que "ayuden a refrenar a la jerarquía y la dominación". ${ }^{44}$ Estas organizaciones es preciso que cumplan con la tarea que se les ha asignado como procesadoras de los conflictos que se puedan presentar entre los diversos grupos que disputan el poder. Es menester que estas instituciones procuren lograr defender los derechos de los grupos que no poseen un poder igual al que detentan otras agrupaciones. O como lo diría Przeworski:

\footnotetext{
${ }^{43}$ Ackerman, John. Ibíd. Pág. 299.

${ }^{44}$ Dahl, Robert. Los dilemas del pluralismo democrático. $1^{\circ}$ Edición en español. Editorial Alianza y Consejo Nacional para la Cultura y las Artes. México. 1991. Pág. 40.
} 
las instituciones democráticas deben de ser 'justas' en el sentido de que todas las mayores fuerzas políticas tengan una posibilidad razonable para avanzar en sus objetivos dentro de la estructura institucional, pero también deben proteger los intereses de aquellas fuerzas que repetidamente pierden en la competencia democrática. ${ }^{, 45}$

Ligado a este punto está el concepto que Leonardo Morlino acuñó como lo es el de calidad de la democracia. Por calidad de la democracia se entiende "aquel ordenamiento institucional estable que mediante instituciones y mecanismos que funcionan correctamente consiguen la libertad y la igualdad de los ciudadanos“. ${ }^{46}$ Existe la calidad en tres aspectos según Morlino, en sus procedimientos, contenidos y resultados. Morlino tomó el término de la calidad con que se mide un producto en el mercado.

La primera forma de calidad viene dada por los procedimientos en la fabricación de un producto, que esto quiere decir que la fabricación debe ser precisa y controlada en tiempo y forma. La segunda forma de calidad hace referencia al contenido que poseen ciertos productos esto es que es preciso que posean determinadas características que lo hacen apto para ser usado. Mientras que la calidad en los resultados está relacionada con la satisfacción indirecta del consumidor que tras probar el producto desearía volverlo a comprar. ${ }^{47}$

\footnotetext{
${ }^{45}$ Przeworski, Adam. Sustainable democracy. $1^{\circ}$ Reimpresión.Cambridge University Press. Estados Unidos. 1996.Pág. 42.

${ }^{46}$ Morlino, Leonardo. Democracias y democratizaciones. $1^{\circ}$ Ed.Centro de Investigaciones Sociológicas. Madrid. 2009.Pág. 186

${ }^{47}$ Morlino. Leonardo. Ibíd. Pág. 185.
} 
Estos tres aspectos conforman los elementos que se entienden dentro del concepto de calidad. También es preciso señalar que una democracia de calidad es cuando "todo un régimen ampliamente legitimado, que satisface completamente a los ciudadanos". ${ }^{48}$ Este aspecto se nombra calidad en términos de resultados.

La calidad en términos de contenido hace referencia a que los ciudadanos, asociaciones y comunidades gozan de libertad e igualdad. Por último, la calidad en términos de procedimiento es "el monitoreo de la aplicación de las leyes vigentes, la eficacia de las decisiones tomadas por el gobierno, la responsabilidad y la rendición de cuentas políticas de los gobernantes electos en relación con la demandas expresadas por la sociedad civil." 49

Estrechamente unida a este término de calidad de la democracia y ligado al concepto de poliarquía, está la definición de Perez-Liñan y Corbetta sobre la calidad de la democracia "es la capacidad de aprovechar el potencial único que la poliarquía ofrece en tanto régimen político". ${ }^{50}$ La calidad de la democracia permite que los ciudadanos sean satisfechos y que por lo tanto haya estabilidad en las instituciones políticas.

La calidad de la democracia reivindica que no sólo es preciso que después de una transición a la democracia haya elecciones periódicas,

\footnotetext{
${ }^{48}$ Morlino, Leonardo. "Calidad de la democracia. Notas para su discusión”. En Cansino, César y Israel Covarrubias (Coord.) Por una democracia de calidad. $1^{\circ}$ Ed. Centro de Estudios de Política ComparadaEducación y cultura, AsesorÍa y Promoción, S.C . México.2007. Pág. 29.

${ }^{49}$ Morlino, Leonardo. Ibíd. Pág. 30.

${ }^{50}$ Citado en Barreda, Mikel. "La calidad de la democracia. Un análisis comparado de América latina. Política y gobierno. Vol. XVIII. No. 2. $2^{\circ}$ semestre. 2011. Pág. 267.
} 
competitivas y con opciones reales, sino que la calidad de la democracia “es más que elecciones pero reconocen que no puede ser menos". 51

Esto quiere decir que la democracia representativa tiene un mínimo debajo del cual no se puede decir que sea una democracia de calidad. Mientras que es posible que no sólo sean las elecciones a cargos públicos lo que se entienda como democracia sino que otros elementos que conforman también a la democracia.

Las dimensiones que conforman la calidad de la democracia dentro de la dimensión procedimental son los siguientes: a)Estado de derecho; b)rendición de cuentas electoral; c)rendición de cuentas interinstitucional; d)participación; e) competencia partidaria. Mientras que las otras dimensiones sustantivas: a) respeto pleno de los derechos y b) mayor igualdad política, social y económica. Por último está la responsabilidad (Responsiveness). ${ }^{52}$ Para esta investigación, se basará en dos aspectos del concepto de calidad de la democracia, rendición de cuentas electoral y rendición de cuentas interinstitucional. Estos aspectos hacen referencia a la calidad con respecto a la dimensión procedimental.

Para Morlino, la rendición de cuentas se basa en dos presupuestos de la tradición liberal que son la evaluación de la responsabilidad del gobierno por parte de los ciudadanos y la otra es que los ciudadanos

\footnotetext{
${ }^{51}$ Méndez, Irma. "Calidad de las elecciones y los institutos electorales estatales: las elecciones a gobernadores en 2010 en México". En López Montiel, Gustavo (et al.).Los estados en el 2010. El nuevo mapa del poder regional. $1^{\circ}$ Edición.UNAM-IEEG-Gernika-Tecnológico de Monterrey. México. 2011. Pag. 595.

${ }^{52}$ Morlino, Leonardo. Calidad democrática entre líderes y partidos. Working paper. IFE. Pág. 6.
} 
son los únicos agentes que conocen sus necesidades y parten de allí para evaluar a sus gobernantes.

También el autor, propone que una democracia dónde el gobierno de la ley y la rendición de cuentas son garantías de calidad es una democracia efectiva. Las característica que posee este aspecto es que las leyes hagan responsables a los gobernantes de sus actos.

Una democracia de calidad es una democracia buena según los términos de Morlino. Los elementos que es preciso que contenga una democracia de calidad son los siguientes: a) democracia efectiva (garantía real de libertad y realización de igualdad y Estado de derecho fuerte), b) democracia responsable (que haya libertad e igualdad y accountability que se respete), c) democracia legítima (alta responsiveness y sociedad civil fuerte $\mathrm{y}$ satisfecha) $\mathrm{y} \quad \mathrm{d}$ ) democracia liberal (que tengan características procedimentales con predominio de la libertad por sobre la igualdad). ${ }^{53}$

Estas dos dimensiones que se abordarán están ligadas a la rendición de cuentas. Hasta este punto es importante destacar que la transparencia "necesariamente genera rendición de cuentas". ${ }^{44} \mathrm{La}$ razón que la transparencia es la capacidad de exponer a la luz pública los hechos de los funcionarios públicos mientras que la rendición de cuentas implica la capacidad de exigir respuestas y de sancionar.

\footnotetext{
${ }^{53}$ Morlino, Leonardo. Democracias y democratizaciones. $1^{\circ}$ Ed.Centro de Investigaciones Sociológicas. Madrid. 2009.Pp. 206-207.

${ }^{54}$ Fox, Jonathan. "Transparencia y rendición de cuentas". En Ackerman, John (Coord). Más allá del acceso a la información. IIJ-Siglo XXI Editores-Universidad de Guadalajara-Cámara de DiputadosCETA. México. 2008. Pág. 174.
} 
Por rendición de cuentas se entenderá "el conjunto de instituciones, normas y procedimientos que tienen como propósito fortalecer la legalidad y el sentido democrático de las responsabilidades públicas y sancionar (positiva o negativamente) a los actores que las asumen". 55 Desde esta definición los autores Merino y López Ayllon demuestran que la rendición de cuentas de instituciones es preciso que se auxilien entre ellas para que sus procedimientos y normas se hagan cumplir.

En palabras de Guillermo Cejudo la rendición de cuentas es "ese conjunto de relaciones de rendición de cuentas forma un entramado constitucional, que bien diseñado, puede generar sinergias y reforzar la efectividad de cada mecanismos aislado y de la rendición de cuentas en general". ${ }^{56}$ Pero a pesar de que es preciso que haya un conjunto de instituciones que hagan posible la rendición de cuentas, es inevitable que existan huecos que generen que no haya una efectiva rendición de cuentas.

Por otra parte, existe la rendición de cuentas horizontal y la vertical. La primera se refiere "a la competencia libre e institucionalizada". 57

La definición de rendición de cuentas horizontal es que son “instituciones estatales que tienen autoridad legal y están fácticamente dispuestas y capacitadas para emprender acciones que van desde el

\footnotetext{
${ }^{55}$ López Ayllon, Sergio y Mauricio Merino. "La rendición de cuentas en México: perspectivas y retos". En Merino, Mauricio, Sergio López y Guillermos Cejudo (Coord.). La estructura de la rendición de cuentas en México. [en línea]. IIJ. México. 2010.Pág. 9. Formato html, Disponible en Internet: http://www.bibliojuridica.org/libros/libro.htm?l=2800.

${ }^{56}$ Cejudo, Guillermo. La construcción de un nuevo régimen de rendición de cuentas en las entidades federativas. Serie Cultura de la Rendición de Cuentas. ASF. México. 2009. Pág. 26.

${ }^{57}$ O`Donnell, Guillermo. Disonancias. Críticas a la democracia. Prometeo Libros. Argentina. 2007. Pág. 86 .
} 
control rutinario hasta sanciones penales o incluso impeachment, en relación con actos de omisión de otros agentes o instituciones del Estado." ${ }^{.58}$

En este tipo de rendición de cuentas también se encuentran involucrados el sistema legal que debe de disponer de órganos de evaluación independientes, de una oposición política vigilante y de medios de comunicación y la participación activa de la sociedad civil.

Todos estos elementos permiten que haya una mejor accountability horizontal y que se presente un ciclo dónde el Estado de derecho refuerza el ejercicio de la accountability y éste mejora el sistema legal y al propio Estado de derecho que genera una mayor responsiveness. ${ }^{59}$ La rendición de cuentas vertical está unida a la dimensión electoral. El rubro electoral abarca otros aspectos como las contiendas electorales. La realización de elecciones donde los ciudadanos por medio del voto permiten que el gobierno en turno sea premiado con la permanencia o castigado no dándole su voto debido a sus acciones.

También es menester señalar que la rendición de cuentas vertical es un poder desigual entre los ciudadanos y sus representantes. La celebración de elecciones es periódica y el electorado solamente puede hacer valer su derecho de retirar su apoyo a sus representantes en este tiempo. Por lo que Morlino menciona que un control importante lo debe

\footnotetext{
${ }^{58}$ O'Donnell, Guillermo. “Accountability horizontal: la institucionalización política de la desconfianza política”. Revista Española de Ciencia Política. No. 11. Oct. 2004. Pág. 12.

${ }^{59}$ Morlino, Leonardo. Democracias y democratizaciones. $1^{\circ}$ Ed.Centro de Investigaciones Sociológicas. Madrid. 2009.Pp. 200-201.
} 
de ejercer la oposición en la cámaras de representantes para que pueda lograr una mejor rendición de cuentas vertical. ${ }^{60}$

Ahora es importante destacar que el término de rendición de cuentas posee tres aspectos que lo conforman: el primero es la información, el segundo es la justificación y la última es en dado caso el castigo. ${ }^{61}$

La entidad encargada de pedir cuentas por los hechos de los funcionarios lo lleva a cabo por medio de informes y a través de explicaciones. Esto significa que se debe de justificar el ejercicio del poder a través de la sumisión al Estado de derecho. La restricción al poder es un ámbito que se hace posible por medio de la rendición de cuentas. La limitación al poder se da cuando un funcionario por medio de la ley asume su responsabilidad por sus actos.

Estas dos definiciones que se usarán en el ámbito político vienen dadas por prácticas realizadas y propuestas por organismos financieros internacionales, por la implementación de las prácticas de la nueva administración pública y las lógicas participacionistas populares que son impulsadas por la izquierda. ${ }^{62}$ La rendición de cuentas proviene además de lo que se mencionó en la oración anterior, por "una respuesta a la incapacidad de los gobiernos para reformarse a sí mismos, crear una

\footnotetext{
${ }^{60}$ Morlino, Leonardo. Ibíd. Pág. 194.

${ }^{61}$ Schedler, Andreas. ¿Qué es la rendición de cuentas?. $8^{\circ}$ Edición. Cuadernos de Transparencia. IFAI. México. 2008. Pág. 13.

${ }^{62}$ Véase Olvera, Alberto. "Los discursos de la participación y de la rendición de cuentas en el contexto internacional de finales del siglo XX". En Isunza, Ernesto y Ernesto Olvera (coord.). Democratización, rendición de cuentas y sociedad civil. CIESAS-Miguel Ángel Porrúa. México. 2010. Pp. 371-385.
} 
burocracia profesional y responsable, y abrir sus cuentas al escrutinio público. $^{63}$

Es importante destacar que existen otros conceptos que pueden ayudar a entender el proceso que es preciso que siga una elección es la de competitividad y competencia. La competencia tiene como característica "la falta de control monopólico, es decir, la presencia de más de un competidor; por el otro lado, un elemento institucional: reglas consensuadas y confianza mutua". ${ }^{64}$

Estas reglas que es preciso que se establezcan deben de basarse en la realización de elecciones libres y justas. Hay que mencionar que para que haya competencia es menester que exista más de un competidor o en otras palabras que no se presente un control monopólico por parte de un competidor.

Otro de los aspectos que abarca la competencia es la nocompetitividad y la competitividad. Por lo tanto, la competitividad es una parte de la competencia. La competitividad electoral hace referencia a "la distribución de la fuerza electoral entre éstos [partidos políticos] en una elección determinada". ${ }^{65}$ Los aspectos que abarca la competitividad son: “a)cuando los partidos principales se aproximan a una distribución casiniveladora de fuerza electoral; b)cuando dos o más partidos obtienen

\footnotetext{
${ }^{63}$ Olvera, Alberto .Ibíd. Pág. 380.

${ }^{64}$ Méndez, Irma. "Competencia y competitividad electoral: dos conceptos clave de la transición democrática”. Polis. Vol. 1. 2003. Pág. 32.

${ }^{65}$ Méndez, Irma. "Transición y consolidación democrática en México: ¿es posible una regresión?.Revista Facultad de Derecho. No. 247. Enero-Junio. 2007. Pág. 71.
} 
resultados cercanos y ganan con escaso margen, y c)por la frecuencia con la cual los partidos se alternan en el poder". ${ }^{66}$

La crítica que se puede hacer a la democracia procedimental es que se piensa que realizar elecciones es el único aspecto importante. Pero se olvida que existen gobiernos autoritarios (autoritarismo electoral) que celebran elecciones pero que violan las características mínimas que requiere una democracia. Esto quiere decir que una contienda electoral por sí sola no garantiza que se cumplan los requisitos mínimos de una democracia procedimental.

Por tal motivo, habría que agregar que existen otros elementos que hacen que haya una verdadera competencia electoral. Entre ellas podemos encontrar "las normas electorales, la forma en cómo se conducen las elecciones y el proceso de conteo de votos que determinan, en gran medida, la existencia o no de condiciones de 'mercado' para una competencia justa y libre". ${ }^{67}$ Las elecciones competitivas revelan "fuerza e independencia de los contendientes, la posibilidad de alternancia y, por tanto, la existencia de competencia real por el poder entre dos o más contrincantes". 68

\section{5.-Financiamiento.}

Ligado a las características del IFE como organismo autónomo electoral, también es relevante estudiar otro aspecto como lo es el

\footnotetext{
${ }^{66}$ Méndez, Irma. Opus Cit. Pág.20.

${ }^{67}$ Mendez, Irma. "Competencia y competitividad electoral: dos conceptos clave de la transición democrática". Polis. Vol. 1. 2003. Pp.36-37.

${ }^{68}$ Méndez, Irma. Ibíd. Pp. 38-39.
} 
financiamiento en las elecciones. Si bien el IFE posee la facultad de realizar las elecciones también tiene la tarea de revisar que el financiamiento que perciben los partidos políticos esté de acuerdo a la normatividad. Por tanto, en el presente apartado es necesario revisar qué es el financiamiento y las características que posee.

En primer término se debe de tener en cuenta el aspecto teórico del financiamiento y la discusión que hay en torno a este tema. Con base en la clasificación propuesta por Herbert Alexander, se distinguen tres formas con que los partidos político se allegan de recursos en las democracias occidentales: el financiamiento privado en sus dos modalidades interno y externo y el subsidio estatal. ${ }^{69}$

El financiamiento público que reciben los partidos políticos busca que estas organizaciones puedan cubrir los gastos a los que tienen que hacer frente. Este tipo de financiamiento procura que los partidos tengan recursos para cubrir los gastos ordinarios de sus actividades permanentes y en épocas de campaña para que obtengan el voto de los ciudadanos.

Además esta modalidad de subvención de los partidos políticos ayuda a que se financien educación, capacitación de los ciudadanos y también en la publicación de medios que difundan investigaciones realizadas.

Este tipo de financiamiento que reciben los partidos políticos es debido a que éstos constituyen un elemento importante de la democracia. Los partidos políticos cumplen la función de representar la pluralidad de intereses y posiciones dentro de la sociedad. Por tanto "entidades de

\footnotetext{
${ }^{69}$ Barquín Álvarez, Manuel. "El financiamiento de los partidos políticos en México, en la reforma de 1993". En Pérez Fernández del Castillo, Germán y Arturo Alvarado (Coord.). La voz de los votos. Un análisis crítico de las elecciones de 1994. Miguel Ángel Porrúa-Flacso. México. 1995. Pág. 40.
} 
auténtico interés público cuya existencia merece ser apuntalada con fondos públicos". ${ }^{70}$

La cobertura de los gastos de los partidos políticos debe de cumplir con la función de evitar que los candidatos y partidos políticos puedan ser cooptados por intereses económicos de grupos oligárquicos. Inicialmente esta subvención estatal, se concibió como un medio para lograr mayor equidad y condiciones de competencia menos desigual entre los partidos políticos financiados por los grandes intereses económicos. Detrás de esta fórmula donde se busca que el financiamiento a los partidos políticos está el hecho de que haya una mayor equidad en la contienda electoral.

En este ámbito es preciso recordar que el recurso monetario que gozan los partidos políticos, si bien está brindado por el Estado y por particulares, existen graves riesgos que los desequilibrios generados por el mercado se vea reflejado en la política. Los mecanismos de financiamiento público directo cumplen una función de nivelación de las oportunidades políticas, bajo el supuesto de que un financiamiento predominantemente privado introduciría situaciones de desigualdad entre los contendientes.

Al hablar de condiciones de nivelación de oportunidades, puede entonces entenderse la importancia del momento del desembolso de recursos públicos en aquellos países donde no hay financiamiento permanente. Reforzando el argumento dado anteriormente, es menester tener en cuenta que las desigualdades económicas se pueden trasladar al proceso político a

\footnotetext{
${ }^{70}$ Woldenberg, José. La construcción de la democracia. Plaza y Janés. Editores. México. 2002. Pág. 292.
} 
través de dos vías al menos. La primera es mediante las contribuciones a la campaña electoral, que puede verse como un medio indirecto de obtener votos.

Si las donaciones políticas son elásticas respecto a la renta (esto es, si se comportan como bienes normales), los individuos con rentas altas pueden ejercer mayor influencia sobre el resultado electoral que los que hacen aportaciones pequeñas o no contribuyen. La segunda vía por la que la posición económica puede contribuir a las desigualdades políticas opera a través de las oportunidades de ocupar puestos de representación pública donde el financiamiento de las campañas electorales corre a cargo de los candidatos.

También es menester que se tenga en cuenta que los partidos políticos al recibir financiamiento del Estado, pueden generar que éstos se alejen de los ciudadanos. Se provoca que haya una estatización y burocratización además de una osificación que es la dependencia del dinero que reciben del Estado los partidos políticos.

Por otra parte, el financiamiento público se puede dividir en tres ámbitos: a) directo; b) indirecto y c)mixto. El primero hace referencia a los recursos económicos que reciben los partidos políticos del Estado. El segundo es por medio de las prestación de algún servicio por parte del Estado a las organizaciones políticas como servicios, infraestructura y acceso a medios de comunicación. El último alude a la mezcla de los dos aspectos anteriormente mencionados.

En el rubro de financiamiento privado es preciso tener en cuenta que puede ser interno y externo. En este tipo de subvención se puede dar 
por medio de las aportaciones de los afiliados a un partido (financiamiento por cuotas), las aportaciones de los miembros que ocupan cargos de elección popular, ingresos derivados por publicaciones y eventos sociales $\mathrm{y}$, por último, los derivados de inversiones $\mathrm{y}$ bienes inmuebles además de los préstamos obtenidos por entes financieros privados.

Cuando se habla de financiamiento privado se debe de tener en cuenta que existen ciertas restricciones a este tipo de subvención. La prohibición de que los partidarios hagan contribuciones que rebasen cierto tope establecido en la ley electoral. Además de que también las donaciones individuales o colectivas poseen límites que están escritos en la normatividad.

A este respecto se precisa reconocer que existen algunas instituciones que las leyes electorales vedan para que puedan realizar contribuciones financieras o en especie. Los sindicatos, iglesias, empresas mercantiles nacionales o extranjeras, empleados gubernamentales son vedados de participar.

Pero por otra parte, aunque la normatividad con respecto al financiamiento de los partidos políticos posee límites claros, esto son evadidos por medio de otras estrategias por los individuos o colectivos que pretenden aportar más allá de lo que establece la ley. Por lo tanto se debe de tener en cuenta que "al momento de implementar límites al financiamiento de los partidos se tiene que tomar en cuenta que dichos 
límites, para disminuir la influencia de ciertos intereses, pueden provocar la influencia de otros nuevos a expensas de aquéllos". ${ }^{71}$

En una situación así los recursos económicos constituyen un bien complementario de la actividad política, ya que los candidatos con riqueza personal disponen de ventajas a la hora de costear sus campañas.

Otro aspecto que es preciso tener en cuenta es el medio en el cual se presentan las campañas electorales. La necesidad no sólo de mantener aparatos partidarios en funcionamiento permanente sino, además, la de llevar a cabo campañas electorales crecientemente costosas, ha colocado a los partidos frente al problema de recaudar grandes sumas sin indagar muchas veces el origen de esos dineros, o incluso, cerrando los ojos ante lo obvio de los hechos. Se ha ido abriendo así, paulatinamente, la puerta al financiamiento ilegal, al predominio cada vez mayor de fuertes grupos económicos, al tráfico de influencias y al flagelo del narcofinanciamiento. ${ }^{72}$

Respecto a este punto que se mencionó anteriormente, Daniel Zovatto menciona que:

...en relación con el origen de las contribuciones, en América Latina, al igual que en Europa y en Estados Unidos, los partidos han sufrido una disminución significativa de las cuotas de los afiliados, mientras que el mayor volumen de las contribuciones proviene de las grandes corporaciones... Si bien esta modalidad de financiamiento se caracteriza por la dificultad para ser detectada debido a la hábiles y variadas formas que asume, su influencia puede ser

\footnotetext{
${ }^{71}$ Portilla Martínez, Adolfo Sergio. Los problemas del financiamiento a los partidos políticos .Una comparación entre México y España. Tesis de licenciatura. Facultad de ciencias políticas y sociales. UNAM. México. 2011. Pág. 66.

${ }^{72}$ Zovatto, Daniel. "El financiamiento electoral: subvenciones y gastos". En Zovatto, Daniel, Dieter Nohlen .Tratado de derecho electoral comparado en América Latina. 2da. Edición. FCE-IFE-IDEA Internacional y Tribunal del poder judicial de la Federación. México- 2007. Pág. 746.
} 
medida sobre la base de los escándalos producidos en diferentes países [Bolivia, Colombia, Panamá, y Venezuela entre otros]. ${ }^{73}$

Una forma de financiamiento que también se presenta en las contiendas electorales es la llamada ingresos atípicos. Estos ingresos atípicos son "vías de financiamiento que no se encuentran dentro de la estricta legalidad y que están en la línea fronteriza de la corrupción y el delito", 74

Las dos formas en que se presentan este tipo de financiamiento es por medio de subvenciones o por el sottogoverno. La primera se refiere a instituciones que aportan fondos a los partidos políticos por medio de personas o entidades interpuestas. La segunda se realiza a través de la administración pública que concede contratos a empresas privadas que se prestan a dar dinero a un partido.

\section{6.-Fiscalización.}

Cuando se habla del término de financiamiento, como se hizo en el apartado anterior, indirectamente se hace referencia a otro concepto como fiscalización. Otra de las atribuciones que posee el IFE y que se establece en el COFIPE es la fiscalizar los recursos de los partidos políticos. Por tal motivo, es preciso conocer qué es la fiscalización y cuáles son sus características de esta forma de vigilancia electoral.

\footnotetext{
${ }^{73}$ Zovatto, Daniel. Ibíd. Pág. 752.

${ }^{74}$ Jímenez Ruiz, Francisco Javier. Financiamiento a partidos políticos y teoría de juegos. Miguel Ángel Porrúa-Universidad Juárez Autónoma de Tabasco-Cámara de Diputados. México. 2005.Pág. 155.
} 
La fiscalización son "los criterios y procedimientos y mecanismos para hacer más completos y exhaustivo el proceso de rendición de cuentas sobre el origen y destino de los recursos financieros manejados por los partidos políticos". ${ }^{75}$

También es de suma trascendencia saber que la fiscalización hecha por un organismo autónomo electoral de este aspecto con los recursos dados a los partidos políticos busca llevar "actividades preventivas, normativas, de vigilancia, de control operativo $y$, en última instancia, de investigación". 76

Las ideas que subyace detrás del concepto de fiscalización están la transparencia, la equidad y la igualdad en el nivel de los partidos políticos. Conocer el destino de los recursos que se brindan a los organizaciones políticas para las elecciones, sean éstas presidenciales o estatales, busca que los ciudadanos tengan más control y que la rendición de cuentas se establezca sobre los representantes políticos que ejercen el poder.

Otro de los objetivos que procura cumplir la fiscalización a los partidos políticos es que evita que surjan problema que generen distorsiones en el sistema democrático además de eliminar la discrecionalidad, impunidad y corrupción. $^{77}$

\footnotetext{
${ }^{75}$ Guerrero, Eduardo. Fiscalización y transparencia del financiamiento a partidos políticos y campañas electorales. Dinero y democracia. Auditoria Superior de la Federación. Serie: cultura de la rendición de cuentas. México. 2003. Pág. 40.

${ }^{76}$ Agiss Bitar, Fernando. Fiscalización de los recursos de los partidos políticos. Serie Temas Selectos de Derecho Electoral. TEPJF. México. 2008. Pág. 12.

${ }^{77}$ Cruz Cruz, María Irene. Fiscalización al financiamiento público otorgado a los partidos políticos. Tesis de licenciatura. Facultad de Derecho. UNAM. México. 2009. Pág. 36.
} 
Una crítica que se hace a la fiscalización de los recursos que reciben los partidos políticos proviene de Alonso Lujambio. Este autor menciona que las autoridades electorales no debieran verificar el origen y destino de los recursos de los partidos sino más bien el cumplimiento de las normas que rigen la procedencia y finalidad del dinero dado a los partidos. El argumento que subyace detrás de esta sentencia, es que las normatividades específicas que se desean hacer valer junto con los bienes jurídicos que pretende tutelar la norma, ayudarán a saber si estos instrumentos son adecuados o inadecuados.

El punto que buscó explicar Lujambio es que aunque una institución electoral tenga los medios adecuados para realizar su tarea de fiscalización sino no posee los instrumentos propicios no podrá hacer su tarea con puntual eficacia. No sólo se necesitan instrumentos directos sino también indirectos.

Los instrumentos directos hacen referencia a la auditoria de los gastos de los partidos políticos. Mientras que los instrumentos indirectos se refieren al conocimiento que tiene la autoridad electoral acerca de irregularidades que le hacen saber otras instituciones públicas o $\operatorname{privadas}^{78}$, y también hay que mencionar la utilidad de la publicidad, monitoreo de gastos, información financiera de los partidos políticos. ${ }^{79}$

\footnotetext{
${ }^{78}$ Fragoso Sánchez, María Lina. Fiscalización al financiamiento de los recursos de los partidos políticos nacionales y su órganos fiscalizador. Tesis de licenciatura. Facultad de Derecho. UNAM. México. 2011. Pp. 10.

${ }^{79}$ Lujambio, Alonso. "La fiscalización de los gastos de los partidos políticos". En Zovatto, Daniel, Dieter Nohlen (comp.). Tratado de derecho electoral comparado en América Latina. 2da. Edición. FCEIFE-IDEA Internacional y Tribunal del poder judicial de la Federación. México. 2007. Pág. 824.
} 
En este tipo de sistema es donde intervienen instrumentos directos como indirectos proveen la posibilidad de tener más certeza acerca de las posibles violaciones a la ley del financiamiento a los partidos políticos.

Los órganos autónomos electorales que se han establecido en cada país están encargados constitucionalmente de llevar a cabo la fiscalización de los recursos brindados a los partidos políticos. Las características que es preciso que posean estas instituciones son independencia, apartidistas y tener facultades de "hacer citaciones, proteger a informantes y acceder a cuentas bancarias". 80

Estas instituciones que están encargadas de realizar la tarea de las fiscalización de los recursos que reciben los partidos políticos, es menester que estén provistas de los mecanismos de castigo que en caso que se requiera hace uso de su poder institucional.

Otro de los elementos que genera problemas al momento de hacer los procesos de fiscalización es la interpretación que se puede realizar de una ley. Es decir, si no existe claridad en la definición de los conceptos clave que ayuden a hacer con precisión la tarea de la fiscalización no se podrá llevar a cabo una eficaz auditoria a estos procesos de rendición de cuentas.

\section{7.-Legalidad.}

En los dos apartados que continúan se abordarán dos conceptos que forman parte de los valores rectores del IFE. El primero es el legalidad y posteriormente el de imparcialidad.

\footnotetext{
${ }^{80}$ Guerrero, Eduardo. Ibíd. Pág. 30.
} 
Cuando se habla de legalidad se refiere a que cada decisión que se tome en el ámbito de la aplicación de las leyes debe de estar basada en la ley y no de manera tornadiza. La ley forma parte de un sistema jurídico en un sistema político. Toda institución que pertenezca al Estado mexicano es preciso que se apegue a las reglamentaciones que estén en vigencia en el momento. Las características que es menester que tenga la legalidad es que sea pronta y obligatoria.

Detrás del principio de legalidad, está el Estado de derecho. En dónde el Estado de derecho y sus instituciones y sus decisiones deben de estar configuradas, supeditadas y al "bloque de la legalidad". Es decir, "la legalidad es la regla de oro... y en el carácter actúa como parámetro para decir que un Estado es un Estado de derecho". ${ }^{81}$

La violación del principio de la legalidad se presenta cuando se comenten de dos formas: la primera es por abuso del ejercicio de las potestades y por exceso. El primer término hace referencia cuando se hace uso de la potestad pero con fin distinto. Mientras que cuando se utiliza por exceso es debido a que se ejerce la potestad más allá del límite establecido por la soberanía. ${ }^{82}$

\footnotetext{
${ }^{81}$ Martínez Espinoza, Yanella. El proceso electoral de 2006:las instituciones electorales entre la legalidad y la legitimidad. La importancia de una Reforma Política Electoral en México. Tesis de licenciatura. FES Acatlán. UNAM. México. Pág. 22.

${ }^{82}$ Véase.Rosales Castro, Emmanuel Alejandro. Las facultades discrecionales como violación al principio de legalidad. Tesis de licenciatura. Facultad de derecho. Universidad Lasallista Benavente. Celaya. México. 2009. Pág. 101.
} 


\section{8.-Imparcialidad.}

El último concepto que es menester estudiar es la imparcialidad. Es preciso recordar que uno de los valores rectores del IFE es la imparcialidad. El objeto de estudio de esta tesis es el estudio del IFE ante el caso Monex, es preciso comprender el significado de esta noción porque se medirá en el capítulo tercero.

Por imparcialidad se entenderá "como la ausencia de prejuicio o de previa toma de partido". ${ }^{83}$ La imparcialidad también está compuesta por aspectos tales como la ausencia de desviaciones sutiles de la objetividad.

Esto quiere decir que "la imparcialidad excluye el favoritismo basado en la amistad, semejanza racial o de clase, entre otras cosas". 84 En otras palabras, la imparcialidad de una persona o institución que toma decisiones es porque actúa sin temores o preocupaciones. La imparcialidad precisa que cuando se decida "no se perjudique o beneficie mediante una acción indebida o ilegal a ninguno de los participantes en la contienda electoral". ${ }^{85}$

Cuando se realiza una toma de decisiones es preciso que se precise por qué se adoptó tal decisión. Esto es, que se deben de enumerar las

\footnotetext{
${ }^{83}$ Valldecabres Ortiz, María Isabel. Imparcialidad del juez y medios de comunicación. Universitat de València y Tirant lo Blanch. Valencia. 2004. Pág. 700.

${ }^{84}$ Barry, Brian. Teorías de la justicia. $1^{\text {a }}$ Ed. Gedisa Editorial. Barcelona. 1995. Pág. 308.

${ }^{85}$ Andrade Sánchéz, Eduardo. Derecho constitucional. Oxford University Press. México. 2008. Pág. 134.
} 
razones públicamente y defenderse públicamente, para que "en principio, sea igualmente aceptable para cualquiera" ${ }^{86}$

Para que exista la imparcialidad es menester que haya un tercero que sea ajeno a ambas partes. No podría haber imparcialidad donde se suscribe un principio o ley que favorezca a una de las partes en disputa, porque a la persona o grupo que es favorecido no rechazaría este hecho mientras que la persona o grupo que tiene una desventaja con este principio o ley desearían rechazarlo.

Lo que pretende el principio de igualdad es poner en situación de igualdad a ambas partes y "facilitarle los medios para que puedan defender adecuadamente sus posiciones" ${ }^{87}$

\section{9.-Conclusiones.}

La democracia procedimental es la que impera en el México. Por tanto, es preciso que haya instituciones que resguarden los elementos clave que precisa este tipo de democracia. Las instituciones electorales hacen cumplir los derechos políticos que poseen los ciudadanos. Mientras las instituciones electorales posean atributos jurídicos e institucionales harán cumplir la función por la cual fueron creadas: los procesos democráticos y hacer respetar la decisión de los ciudadanos.

\footnotetext{
${ }^{86}$ Ídem.

${ }^{87}$ Valldecabres Ortiz, María Isabel.Ibíd. Pág. 101.
} 
Por otra parte, las instituciones electorales garantizan que se respeten los procedimientos y la reglas que norman el proceso electoral. Mientras no se violenten los sistemas y los preceptos se puede hablar de una democracia de calidad. Es decir que haya un procedimiento correcto.

Según los términos de Morlino para que una democracia sea de calidad es preciso que sea ubicada en el rubro democracia efectiva donde impera un Estado de derecho fuerte. Por tanto es preciso que las instituciones electorales hagan prevalecer el Estado de derecho por sobre lealtades personales.

A manera de conclusión de este capítulo, los organismos autónomos electorales juegan un rol fundamental para la democracia procedimental. Este hecho es debido a que estos organismos además de que realizan las elecciones también poseen atribuciones para regular y verificar los recursos económicos que reciben los partidos políticos.

El dinero en la democracia es un elemento esencial porque hace que los partidos políticos hagan campañas electorales y para sus gastos corrientes. Para evitar que exista la entrada de actores que inclinen el destino de una elección, los organismos electorales impiden que suceda esa posibilidad. Además del reparto equitativo de los recursos económicos entre las diversas fuerzas políticas según la ley, de manera que todos tengan la oportunidad de recibir recursos del Estado.

En relación con el dinero, la democracia pone énfasis en el rubro del financiamiento y fiscalización. En un mundo globalizado, el control de los flujos de dinero proveniente de diversos medios es un imperativo de toda democracia, ya que las personas e instituciones que poseen un mayor capital tienen más posibilidades de influir en el rumbo de una 
elección. Por tal razón, los organismos autónomos electorales también se les asigna la tarea hacendaria en el ramo de la política.

Para finalizar este capítulo, es necesario decir que se trató de concatenar la relación que guarda la democracia procedimental con los organismos autónomos electorales. Se mencionó de forma somera al IFE como una institución autónoma del Estado mexicano. En el siguiente capítulo se desarrollará de manera amplia el recorrido histórico de este instituto y su estructura orgánica, poniendo énfasis en el Consejo General y la Unidad de Fiscalización. 


\section{Capítulo 2. El Consejo General y la Unidad de Fiscalización del IFE: reformas y estructura orgánica.}

\subsection{Introducción.}

Para comenzar este capítulo es preciso revisar las modificaciones en materia electoral que ha experimentado el primer organismo electoral como fue la Comisión Nacional de Vigilancia Electoral que se creó en 1946 hasta llegar al actual Instituto Federal Electoral, con sus últimas reformas electorales como fueron las del año 2007. Este panorama proporcionará la visión de los cambios históricos en el ámbito electoral y cómo el IFE ha jugado un papel trascendente en la democratización del país y más en específico en el área de fiscalización a los recursos de los partidos políticos.

También en este capítulo se analizarán las funciones que se le han atribuido al IFE en el Código Federal de Instituciones y Procedimientos Electorales, así como en la misma normatividad interna del Instituto. Estos elementos ayudarán a entender la forma de la composición tanto del Consejo General del IFE así como sus funciones y también la Unidad de Fiscalización de los Recursos de los Partidos Políticos con sus respectivas responsabilidades.

El objetivo del presente capítulo es analizar la manera en que ha evolucionado el modelo de fiscalización electoral a los partidos políticos en México. 


\subsection{De la Comisión Federal de Vigilancia al Instituto Federal Electoral.}

El 7 de enero de 1946 se creó la Comisión Federal de Vigilancia Electoral que fue el primer órgano central para realizar las elecciones federales. Este fue la primera institución que se estableció en el siglo XX para llevar a cabo las elecciones a nivel nacional. Este organismo tuvo la finalidad de centralizar la operación de las elecciones y de esta manera quitar las facultades para hacer las elecciones a los poderes locales y municipales. ${ }^{88}$ Esta Comisión estaba integrada de acuerdo a la ley por sólo los dos partidos políticos más importantes.

Para el año de 1951, por medio de una modificación a la Ley Electoral Federal se cambió el nombre a la Comisión Federal de Vigilancia Electoral. La modificación fue por Comisión Federal Electoral que fue la que perduró hasta el año de 1990. Esta Comisión según la ley, estaba integrada por los partidos políticos más importantes, o sea tres miembros. ${ }^{89}$

En el año de 1973 se modificó la Constitución para que la Comisión Federal Electoral se encargara de llevar a cabo la realización de las elecciones federales. Con este cambio la Comisión estuvo integrada por todos los partidos políticos a nivel nacional. Los partidos que lo integraban en esta ocasión tenían voz y voto dentro de la Comisión.

\footnotetext{
${ }^{88}$ Díaz Ortiz, Ángel. “Autoridades administrativas electorales”. En Tribunal Electoral del Poder Judicial de la Federación. Apuntes de derecho electoral: una Contribución institucional para el conocimiento de la ley como valor fundamental de la democracia. TEPJF. México. 2000. Pág. 168.

${ }^{89}$ Ídem.
} 
La Secretaria de Gobernación estaba al frente de este órgano. Aunado a la incertidumbre que imperaba en la transparencia de las elecciones estaba el hecho que no existía un padrón confiable, ni listas nominales ni credenciales que llenaran los requisitos para la identificación de los votantes. ${ }^{90}$ Esta Comisión Federal Electoral dependía presupuestal y administrativamente de la Secretaria de Gobernación.

Por lo que los partidos políticos de oposición reclamaban que no existía la necesaria imparcialidad por parte de dicha Comisión. Aunque ya existía un lugar donde los partidos de oposición participaban teniendo voz y voto en esta instancia. Esta comisión estaba integrada por el Secretario de Gobernación, un representante de cada una de las cámaras legislativas, un representante de cada partido político con registro $\mathrm{y}$ un notario.

Las modificaciones a la Constitución Política de los Estados Unidos Mexicanos del año de 1977, fueron un paso importante para la transformación de las instituciones en materia electoral. Los artículos 60 y 97 de la Carta Magna fueron algunos de los artículos que fueron modificados. En el artículo 60 se estableció que el Colegio Electoral sería el encargado de calificar las elecciones. Mientras que en el artículo 97, se conformó un recurso de reclamación ante la Suprema Corte de Justicia. Este medio de apelación no permitió que la Corte resolviera en forma definitiva sino que solamente se le proporcionó efectos declarativos. $^{91}$

\footnotetext{
${ }^{90}$ Baños, Marco Antonio. "El IFE: palanca del cambio político en México". En Centro para el Desarrollo Democrático (coord.)Instituto Federal Electoral. 20 años. IFE. México. 2010. Pág. 228.

${ }^{91}$ Martínez Gil, José Pablo y Patricia Macías. "Autoridades electorales jurisdiccionales en México (TEPJF)”. En Corona Nakamura, Luis Antonio y Adrián Joaquín Miranda Camarena.(comps.) Derecho
} 
Además es preciso decir que la reforma de 1977 LOPPE daba a la Comisión Federal Electoral la personalidad jurídica y la obligación del gobierno federal de brindarle presupuesto. También se asentó que las decisiones de la Comisión Federal Electoral no podrían ser revisadas por ninguna autoridad superior. ${ }^{92}$

Por otra parte, la reforma que se hizo en 1977 también procuraba que existiera otra instancia en la cual los partidos políticos inconformes con la calificación de las elecciones que hacia el Colegio Electoral de la Cámara de Diputados pudieran recurrir a Suprema Corte de Justicia de la Nación. En caso que la Suprema Corte tomara el caso, sólo tendría efectos declarativos sobre el proceso y no se podría obligar al Colegio Electoral.

Para el año de 1987, se realizó una nueva modificación a la Comisión Federal Electoral por medio de la creación del Código Federal Electoral. Esta nueva disposición estaría en consonancia con el criterio de representación proporcional. Es decir, que de acuerdo al peso electoral que alcanzara cada partido político en las elecciones, se conformaría la instancia. Se podía ocupar desde un lugar hasta dieciséis lugares en la Comisión.

Electoral Mexicano. Una visión local: Jalisco. Marcial Pons. Ediciones Jurídicas y Sociales, S.A. Madrid. 2010.Pág. 126.

${ }^{92}$ Martínez Gil, José Pablo y Patricia Macías. “Autoridades electorales jurisdiccionales en México (TEPJF)". En Corona Nakamura, Luis Antonio y Adrián Joaquín Miranda Camarena.(comps.) Derecho Electoral Mexicano. Una visión local: Jalisco. Marcial Pons. Ediciones Jurídicas y Sociales, S.A. Madrid. 2010.Pág. 126. 
La Comisión quedó presidida por el Secretario de Gobernación, un senador y un diputado. La asignación de los representantes partidistas fue de la siguiente manera: un representante si el partido había obtenido hasta el 3\% de la votación nacional efectiva, y si había tenido entre el $3 \%$ y $6 \%$ se le agregó uno más. Si el partido había obtenido más del $6 \%$ obtendría un representante por cada $3 \%$ de participación en votos. ${ }^{93}$

El Código Federal Electoral de 1987 dispuso que se creara la Comisión Técnica para la Vigilancia del Registro Nacional de Electores (RNE) y sus 32 Comisiones Locales de Vigilancia. Los partidos políticos estaban representados en dichas comisiones. El Código también instituyó 300 Comisiones Distritales de Vigilancia para el escrutinio del registro de electores en cada distrito donde estaban representados los partidos políticos. El Secretario de Gobernación estaba a cargo de nominar al Director General y al Secretario General del Registro Nacional de Electores. ${ }^{94}$ El RNE estaría obligado a proporcionar las listas de electores básicas y complementarias el $1^{\circ}$ de enero y el $1^{\circ}$ de abril respectivamente y la lista definitiva el $1^{\circ}$ de junio.

El proceso de conteo de votos en este Código hizo que el lapso de tiempo entre el día de las votaciones y el comienzo de la contabilización de los votos en las comisiones distritales se redujera a tres días. La ley LOPPE había establecido el plazo en una semana pero con el nuevo Código Federal Electoral disminuyó a sólo tres días.

\footnotetext{
${ }^{93}$ Méndez, Irma. Transición a la democracia en México. Competencia partidista y reformas electoral 1977-2003.Fontamara-FLACSO México.2006. Pág. 41.

${ }^{94}$ Ídem.
} 
Una de las críticas que se le hacen a la reforma electoral de 1987, es que sirvió para que el PRI tuviera un control sobre la Comisión Federal Electoral. A través de la modificación de la forma de representación dentro de este órgano se dio un cambio que fue poco adecuado para la igual presencia de los partidos políticos nacionales en la toma de decisiones. Es decir el control del partido gobernante en la Comisión Federal Electoral era un hecho.

El cambio que se presentó de la "representación paritaria a la representación proporcional de los partidos dentro de los órganos electorales, era en grande medida el más grande retroceso del Código Federal Electoral en relación a la autonomía e imparcialidad de la Comisión Federal Electoral". ${ }^{95}$

Esta reforma de 1987, tuvo consecuencias en la vida electoral del país porque su aplicación en el año de 1988 donde el presidente Carlos Salinas de Gortari ganó los comisiones presidenciales generó gran incertidumbre en los ciudadanos. La caída del sistema de conteo que estaba a cargo del Secretario de Gobernación Manuel Bartlett provocó que el Frente Nacional Democrático se quejara ante lo que señalaban era una manipulación del sistema de conteo de votos.

"La vida que tuvo el Código Federal Electoral fue muy efímera, debido a que únicamente reguló una elección presidencial, la más polémica y controvertida de la historia de México. Los resultados arrojados por las elecciones presidenciales de 1988, así como la manipulación del proceso mismo regulado

\footnotetext{
${ }^{95}$ Soto Cabrera, Ricardo. Autonomía e imparcialidad del IFE. Tesina. Departamento de Sociología. UAMI. México. 1999. Pág. 53.
} 
por los órganos electorales aceleraron un periodo de reformas dentro del sexenio salinista". 96

Para las elecciones de 1988, en la conformación de esta instancia el PRI tenía 16 mientras que había 15 que eran representantes al Ejecutivo, Legislativos y los representantes de los otros partidos políticos de oposición. $^{97}$

Sin embargo, aunque se dio un proceso de apertura en este órgano la estructura y actividades de la administración electoral dependía de la Secretaria de Gobernación. Por lo que "el personal que trabajaba en el sistema administrativo electoral...estaba formado por un grupo de funcionarios que rendía cuentas sólo al Secretario de Gobernación" ${ }^{98} \mathrm{La}$ validación de las elecciones que se habían quedaba a cargo de los Colegios Electorales de la Cámara de Diputados y Senadores en dónde el PRI conformaba una mayoría.

La reforma electoral que se presentó en el año de 1990, fue de gran importancia porque creó la nueva institución electoral que habría de regir la vida democrática del país.

El año de 1990 fue un momento culminante en la democracia electoral del país debido a que en ese año fue cuando se emitió el Código Federal de Instituciones y Procedimientos Electorales

\footnotetext{
${ }^{96}$ Soto Cabrera, Ricardo. Opus Cit. Pág. 55.

${ }^{97}$ Pérez Manzano, Karina. Estudio de las facultades y responsabilidades del IFE como Organismo Autónomo Constitucional y la perspectiva electoral hacia el 2012. Tesis de licenciatura. Facultad de Ciencias Políticas y Sociales. UNAM. México 2011. Pág. 50.

${ }^{98}$ Méndez, Irma. Transición a la democracia en México. Competencia partidista y reformas electoral 1977-2003.Fontamara-FLACSO México.2006. Pág. 31.
} 
(COFIPE).Se promulgó el 15 de agosto de $1990 .{ }^{99}$ Este código que se creó, fue producto de una consulta pública por medio de la conformación de la Comisión Especial para la Consulta Pública sobre la Reforma Electoral. También los partidos políticos tomaron parte en esta discusión junto con intelectuales que vino dar como resultado el COFIPE. ${ }^{100}$

La creación del Instituto Federal Electoral (IFE) fue un momento culminante de la democracia porque significaba que las elecciones serían realizadas por esta institución. Este acontecimiento que fue plasmado en el artículo 41 de la Constitución Política de los Estados Unidos Mexicanos y que se estableció en el COFIPE despojó a la Secretaria de Gobernación de su antigua labor de realizar las elecciones.

Dentro de las facultades con las cuales se conformó al IFE fueron las siguientes: "1) elaborar el padrón electoral; 2) preparar la jornada electoral; 3)realizar escrutinio, cómputo y otorgamiento de constancias; 4)tener a su cargo la capacitación electoral y la educación cívica; 5) impresión de material electoral; 6)atención a los derechos y prerrogativas de los partidos". 101

Una de las características que poseía el recién creado IFE fue que estaba conformado por personal especializado en materia electoral. La integración del IFE trató de introducir un balance en la participación de los partidos políticos y los representantes de otras instituciones. Un

\footnotetext{
${ }^{99}$ Becerra, Ricardo, Pedro Salazar y José Woldenberg. La reforma electoral de 1996: una descripción general. FCE. México. 1997. Pág. 27.

${ }^{100}$ Pérez Manzano, Karina. Estudios de la facultades y responsabilidades del IFE como órgano autónomo constitucional y la perspectiva electoral hacia 2012. Tesis de licenciatura. Facultad de Ciencias Políticas y Sociales. UNAM. México. Pág. 52.

${ }^{101}$ Becerra, Ricardo, Pedro Salazar y José Woldenberg. Ibíd. Pág. 27.
} 
aspecto que se debe de tomar en cuenta en la reforma electoral del 6 de abril de 1990 fue la integración del IFE por consejeros magistrados. Estos consejeros magistrados tenían que ser totalmente independientes de los partidos políticos y además de actuar con imparcialidad en la toma de decisiones del Consejo General del IFE.

La forma en cómo estaba formada el Consejo General era de la siguiente manera: seis consejeros magistrados que eran propuestos por el presidente de la república y eran aprobados por dos terceras partes de la Cámara de Diputados; por dos representantes de la Cámara de Diputados uno de ellos elegido por la mayoría y el otro por la primera minoría; dos representantes de la Cámara de Senadores, uno de ellos designado por la mayoría y el otro por la primera minoría ${ }^{102}$ y el secretario de Gobernación. Esta nueva estructura impedía que alguno de los partidos políticos tuviera una presencia mayoritaria en los puestos de decisión de la institución.

La reforma electoral del año de 1993 tuvo como propósito que se modificaran varios aspectos en materia electoral que para el PRD y PAN eran necesarias. La reforma electoral de este año tuvo el propósito de asignar mayores responsabilidades al Consejo General del IFE así como la de elegir al secretario general y a los directores ejecutivos del IFE y a los consejeros ciudadanos en los consejos locales. ${ }^{103}$ También esta reforma estuvo encaminada para que los consejeros ciudadanos que conforman los Consejos Locales y Distritales fueran decisivos porque

\footnotetext{
${ }^{102}$ Patiño Camarena, Javier. Nuevo derecho electoral mexicano $2006.8^{\circ}$ Edición. [en línea] IIJ. UNAM. 2006. Pág. 523. Formato html. Disponible en Internet: http://biblio.juridicas.unam.mx/libros/libro.htm?l=1833

${ }^{103}$ Patiño Camarena, Javier. Opus Cit. Pág. 29.
} 
ahora ocuparían nueve lugares mientras que los vocales ejecutivos abarcarían dos posiciones.

Las elecciones presidenciales que se llevaron a cabo en el año de 1994, fueron un momento álgido de la contienda electoral del país. El levantamiento armado del Ejército Zapatista de Liberación Nacional (EZLN) que se presentó el $1^{\circ}$ de enero de 1994 en el estado de Chiapas tuvo un gran impacto político y social en los posteriores acontecimientos que se presentaron a lo largo del año. Otro hecho que jugó un papel importante para las modificaciones electorales fue el asesinato de candidato a la presidencia por el PRI, Luis Donaldo Colosio.

Por tanto, la reforma electoral del 19 de abril de 1994 tuvo como finalidad que se introdujera la figura de "consejero ciudadano" para "ampliar las garantías de imparcialidad en el órgano supremo del IFE". ${ }^{104}$ Este consejero ciudadano venía a sustituir al consejero magistrado que era un abogado. Los consejeros ciudadanos serían elegidos por la Cámara de Diputados por las dos terceras partes y con la propuesta de los partidos políticos.

Para esta reforma de 1994, también se modificó la constitución del Consejo General. Esto es, ahora existía un presidente del Consejo General que era encabezado por el Secretario de Gobernación, seis consejeros ciudadanos, cuatro consejeros del poder legislativo y los representantes de los partidos políticos que contaban con registro. Aunque los partidos políticos ya no tendrían voto dentro del Consejo General y además de que su representación en el Consejo General ya

\footnotetext{
${ }^{104}$ Andrade Sánchez, Eduardo. Derecho electoral. Oxford University Press México. México. 2012. Pág. 221
} 
no sería de acuerdo a su fuerza política sino que habría un representante por partido.

Se abrió el proceso electoral a los observadores electorales extranjeros. Otra de los cambios acaecidos fue que el padrón electoral sería más confiable por medio de una credencial de elector con fotografía. ${ }^{105}$ Es importante decir que constitucionalmente el IFE recibió otra categoría jurídica. El artículo 41 de la Constitución Política de los Estados Unidos Mexicanos mencionaba que la realización de las elecciones era una función del Estado por medio de un organismo público autónomo. Estos organismos tendrían personalidad jurídica y patrimonio propio y la participación en su integración de la Cámara de Diputados.

También los partidos políticos opositores al PRI propugnaron porque el representante del poder ejecutivo dentro del Consejo General de IFE no interviniera en las decisiones tomadas en dicho órgano electoral. El nombramiento del ex rector de la UNAM, Jorge Carpizo Mac Gregor, por parte del presidente Carlos Salinas de Gortari, generó un acuerdo entre los partidos debido a su reputación de imparcialidad que representaba este ciudadano. También es importante destacar que los partidos políticos dentro del IFE dejaron de tener voto dentro del Consejero General.

La reforma de 1996 propuso que el IFE tuviera una plena autonomía ya que se eliminó la intervención del representante del poder ejecutivo en dicha institución. La modificación del artículo 41 constitucional que

\footnotetext{
${ }^{105}$ Pérez Manzano, Karina. Opus cit. Pág. 59.
} 
mencionaría que el IFE es un "organismo público autónomo" iba a estar sujeto a ninguno de los tres poderes, pero era menester que estuviera bajo las obligaciones y responsabilidades que establece la Constitución y el orden jurídico del país. La personalidad jurídica y patrimonio propio es otro de los aspectos que se integraron dentro de la reforma que se realizó en el año de 1996.

La reforma de 1996 planteó que el IFE sería la autoridad en materia electoral y su independencia en sus decisiones y funcionamiento. Con la finalidad de lograr este aspecto, el Consejo General estaría integrado por un consejero presidente y ocho consejeros electorales que tendrían voz y voto.

Los representante de los partidos políticos ante el IFE sólo estarían presentes en los diferentes procesos del IFE, pero no con voto en el Consejo General. El consejero presidente sustituiría al presidente del Consejo que era el representante del poder ejecutivo. Los representante de los partidos que estuviesen representados en la Cámara de Diputados y Senadores o dado el caso sólo en una de ellas, tendrían cabida los "consejeros del poder legislativo" que poseerían voz pero no voto en la toma de decisiones dentro del Consejo General. Otros de los miembros que conformaban el IFE el secretario ejecutivo, los representantes del poder legislativo (representantes de cada uno de los partidos políticos).

\footnotetext{
${ }^{106}$ Andrade Sánchez, Eduardo. Ibíd. Pág. 222.
} 
También la reforma constitucional en materia electoral de 1996 propuso cinco ejes rectores que deberían de regular toda contienda electoral: legalidad, equidad, certeza, objetividad y profesionalismo. ${ }^{107}$

Además de que el IFE realizaría un monitoreo del comportamiento de los medios de comunicación con respecto de la cobertura de diversos candidatos o precandidatos a los puestos de elección popular. El sistema para medir el comportamiento de los medios de comunicación sería a través de la medición del tiempo que los noticieros le proporcionan a cada una de las ofertas políticas.

Algunas organizaciones empresariales también se sumaron a este reclamo por este aspecto de la reforma. El punto que procuraba la modificación era que hubiera equidad en la competición electoral entre los partidos políticos y que los particulares no desequilibraran el asunto a favor o en contra de uno de los candidatos. Debido a que se había realizado un gran esfuerzo para equilibrar la balanza entre los partidos políticos, era necesario que existiera este punto.

La renovación escalonada de los consejeros que integran el Consejo General del IFE fue un punto que se llevó a cabo en la reforma de 2007. Esto fue con la finalidad de permitir que la experiencia acumulada por los integrantes del Consejo fuese transmitida a los nuevos miembros que integrarían al Consejo General. Además de reestablecer la Controlaría General que estaría a cargo de revisar los ingresos y egresos del IFE.

\footnotetext{
${ }^{107}$ Valdés, Leonardo. "Elecciones y legislación electoral”. En Baca Olamendi, Laura (et al.) Léxico de la política. $1^{\circ}$ Reimpresión. CFE-FLACSO-CONACYT-Heinrich Böll Stifung. México. 2004 .Pág. 199.
} 


\subsection{El tránsito de las reformas electorales en materia de fiscalización.}

La modificaciones que se han realizado en materia de fiscalización electoral ha sido un proceso largo de continuas reformas. Hasta este momento, el proceso de reformas que se han hecho en el rubro de fiscalización han propiciado que se establezca un proceso de revisión por parte del IFE de forma más precisa.

La primera instancia en materia electoral fue la Comisión Federal de Vigilancia, este organismo todavía no ponía el énfasis en la materia de fiscalización debido a que el PRI era el que dominaba el ámbito electoral y los demás partidos políticos que existían no poseían el suficiente poder para exigir recursos de parte del Estado.

Pasaron varias modificaciones electorales Las elecciones presidenciales de 1988, en donde el candidato priísta Carlos Salinas de Gortari ganó las elecciones fue un momento cumbre debido a que la oposición encabezada por Cuauhtémoc Cárdenas candidato del Frente Democrático Nacional protestó en contra del fraude electoral que se había realizado en su contra. Por tal razón, el presidente emitió una serie de reformas en materia electoral.

Una de las primeras acciones que se realizaron en materia de fiscalización fue la reforma electoral de 1990. La fiscalización que hacía el IFE se realizaba por una comisión de consejeros que recibían, auditaban y dictaminaban los informes para posteriormente presentar un informe al Consejo General. 
La fiscalización se hacía solamente por medio de una verificación de los informes anuales y de campaña que los partidos políticos daban al IFE, por lo que el instituto carecía de un "mecanismo de auditoria y compulsa para constatar que lo reportado por los partidos políticos efectivamente coincidía con su realidad financiera."

La reforma de 1993 trajo una serie de cambios en materia de fiscalización. Se prohibió que entes estatales, municipales, mercantiles, eclesiásticos y personas físicas y morales dieran donaciones o dinero a los partidos.

En el rubro del financiamiento privado dicha reforma mencionaba que solamente los actores privados podrían aportar el $1 \%$ del monto total del partido a lo largo del año, las aportaciones anónimas no deberían rebasar el $10 \%$ del financiamiento público del total de los recursos dados al partido en el período de un año, la rendición de cuentas por medio del órgano interno del partido y también el reporte de gastos de campañas para comprobar no rebasar el tope de gastos en las elecciones. Esta fue la primera acción para que la que hubiera una equidad en el uso de los recursos públicos.

La reforma en materia electoral que se presentó en 1996 tuvo una gran importancia porque marcó el rumbo que siguieron las elecciones posteriores. Los principales rasgos que se modificaron fueron acerca de la autonomía del IFE y agregaron algunos más relacionados con el subsidio. Los puntos destacados fueron:

a) el financiamiento público predominaría sobre el privado,

\footnotetext{
${ }^{108}$ Fundación Internacional para Sistemas Electorales. Aplicación de la reforma electoral de 2007/2008 en México desde una perspectiva internacional comparada. Primer InformeIFES. 2009. Pág. 64.
} 
b) se estableció las pautas de financiamiento privado y se fijaron límites a estas aportaciones,

c) se prohibió que determinadas instituciones tuvieran participación del financiamiento a los partidos políticos,

d) se determinaron los topes del financiamiento de candidatos,

e) se estableció que solamente los partidos políticos y no terceros podrían comprar propaganda electoral en radio y televisión, y

f) se fijó un sistema de fiscalización de ingresos y egresos de los partidos políticos en el Consejo General del IFE. ${ }^{109}$

El financiamiento público dado por el Estado mexicano sería la principal fuente para la obtención de recursos de los partidos políticos. Este tipo de subvención estaría destinado a cubrir las actividades permanentes de estas organizaciones y también para solventar los gastos electorales y actividades de formación y educación de los militantes.

También es importante destacar que los órganos internos que constituyeron al IFE fueron los siguientes:

a) Fiscalización de los recursos de los partidos y agrupaciones políticas.

b) Prerrogativas, partidos políticos y radiodifusión.

c) Organización electoral.

\footnotetext{
${ }^{109}$ Murayama, Ciro. "Financiamiento a los partidos políticos: el nuevo modelo mexicano". En Salazar, Pedro y Lorenzo Córdova (coord.) Estudios sobre la reforma electoral de 2007. Hacía un nuevo modelo. TEPJF. México. 2008. Pág. 265.
} 

d) Servicio Profesional Electoral
e) Capacitación electoral y educación cívica.

Es importante rescatar es que la reforma de 1996 con respecto al ámbito del financiamiento de los partidos políticos propuso una tesis en la que se basaría la nueva repartición de los fondos estatales. El dinero que recibirían los partidos políticos tenía la intención de procurar tres aspectos: a) transparentar el flujo de dinero, b)equilibrar las condiciones de competencia y c) intentar que los partidos no fueran rehenes de los grandes grupos económicos o peor aún de bandas de delincuentes. ${ }^{110}$

Con respecto al rubro del equilibrio de las condiciones de los partidos políticos era un aspecto esencial para empezar a equilibrar la contienda electoral. Los antecedentes de esta reforma fueron las enormes desigualdades en los gastos que se presentaron en las elecciones anteriores, pero más en específico en el informe que presentó la Comisión de Consejeros Ciudadanos del Consejo General del IFE en 1995 donde reportaba que el PRI gastó el 71\% de su dinero de la contienda presidencial mientras que el PAN usó el 17.8\%, PRD 6.05\% y el PT $1.15 \%$. Esto quiere decir que ya había un documento por parte del IFE que ponía en cifras la disparidad de gasto que existían entre los partidos políticos.

\footnotetext{
${ }^{110}$ Woldenberg, José. "Estampas de la reforma". En Salazar, Pedro y Lorenzo Córdova. (coord.) Estudios sobre la reforma electoral de 2007. Hacía un nuevo modelo. TEPJF. México. 2008. Pág. 27.
} 
A este respecto, el financiamiento público en esta reforma procuraba que los partidos políticos recibieran un financiamiento más equitativa y que las aportaciones de personas físicas y morales fueran taxadas, además de que se hicieron explícitas las fuentes prohibidas de financiamiento para los partidos políticos y también se fijaron los límites a los topes de campaña y se generó un mecanismo de fiscalización de los gastos de los partidos políticos.

Estos puntos que se pusieron en la palestra de la reforma de 1996, fueron importantes porque ya se veían los efectos que podría tener la participación de agentes económicos privados que tenían una enorme relevancia. Teniendo en mente este aspecto y la equidad en el acceso de los recursos monetarios y su control eficaz, la reforma procuró mejores condiciones de competencia para todos los partidos políticos.

Los antecedentes de la reforma de 2007 fueron que antes de abandonar su puesto de consejeros ciudadanos del IFE, en octubre de 2003, los consejeros José Woldenberg, José Barragán, Jesús Cantú, Gastón Luken, Alonso Lujambio, Mauricio Merino, Jacqueline Peschard, Virgilio Rivera enviaron a las dos cámaras del congreso un documento en donde se pedía que se hicieran una serie de modificaciones en materia electoral. Esto hecho se propició por la experiencia que los consejeros poseían en el Consejo General del IFE.

El escrito tenía tres puntos principales, el primero trataba acerca de los gastos y condiciones de competencia. Ya se preveía que los recursos entregados a los partidos políticos terminaban en las arcas de las televisoras. El segundo aspecto era sobre el fortalecimiento del IFE en sus atribuciones de fiscalización, coordinación entre IFE y los institutos 
electorales estatales $\mathrm{y}$, por último algunas sugerencias relacionadas con la realización de las elecciones como poner vigencia a la credencial de elector, la concentración de las elecciones que se llevan a cabo en una sola fecha y rediseño de fórmulas de votación de mexicanos en el extranjero. $^{111}$

Este dato que se mencionó anteriormente deja entrever que ya se habían dado propuestas por parte de consejeros pero que no fueron tomados en cuenta sino hasta que se presentaron algunos hechos que desencadenaron la reforma de 2007.

Los casos que pusieron en alerta al IFE acerca de la entrada de recursos de procedencia no estipulada por la ley, fue el caso de Amigos de Fox y el Pemex gate. El primero hace referencia al financiamiento de particulares a la campaña presidencial del entonces candidato a la presidencia por el PAN Vicente Fox por una cantidad superior a los nueve millones de dólares. Los recursos se canalizaron por medio de asociaciones paralelas a los partidos políticos que estaban ligados al candidato panista.

El rebase de topes de campaña por parte del candidato del PAN a la presidencia y la aportación individuales superior por parte de privados generó que el IFE castigara al PAN con una multa de cuarenta y cinco millones de dólares. Una de las dificultades que tuvo que enfrentar el IFE en su investigación de los Amigos de Fox fue la traba en materia del secreta bancario porque no tenía acceso al mismo.

\footnotetext{
${ }^{111}$ Woldenberg, José. "Estampas de la reforma". En Salazar, Pedro y Lorenzo Córdova. (coord.) Estudios sobre la reforma electoral de 2007. Hacía un nuevo modelo. TEPJF. México. 2008. Pp. 27-28.
} 
La demora a la cual se vio sometido el IFE fue uno de los puntos que se promovieron en la reforma electoral de 2007.

El caso de Pemex gate fue otro de los hechos que provocaron la reforma de 2007. El hecho fue el siguiente, el PRI no reportó al IFE que recibió 50 millones de dólares provenientes del Sindicato de Trabajadores Petroleros. Esta acción tuvo como consecuencia que el IFE multó al PRI con 100 millones de dólares. En los dos casos se ocultó información que ponía en evidencia la implicación de individuos y empresas que violaban la ley con respecto al límite de aportaciones que es permitido realizar a un candidato.

Estos hechos llevaron a que la reforma electoral de 2007 buscara subsanar estas irregularidades. Se puede decir de manera general que la reforma electoral del 2007 se puede dividir en tres aspectos: 1) acceso a los medios electrónicos y su monitoreo; b) fiscalización de los recursos de los partidos políticos y c) la resolución de quejas y conflictos.

Para la fiscalización de los recursos de los partidos políticos se llevaron a cabo varias acciones en la reforma de 2007. Una de ellas fue ayudara que la Unidad de Fiscalización de los Recursos de los Partidos Políticos (UFRPP) tuviera autonomía de gestión con respecto al Consejo General. Esta unidad revisa los informes anuales, precampañas y campañas reportando el total de sus ingresos y egresos ordinarios en los procesos de selección interna y de campañas electorales. Esta Unidad de fiscalización goza de autonomía de gestión para que los integrantes del Consejo General no tuviesen influencia alguna dentro de esta unidad. 
Esta unidad de fiscalización contaría con extensas facultades que le ayudarían en su tarea de investigar el origen de los recursos de los partidos políticos.

Por otra parte, con respecto al financiamiento que obtienen los partidos políticos de sus simpatizantes, la reforma de 2007 menciona que:

"a)la suma de las aportaciones de los simpatizantes a un partido político no puede exceder anualmente el $10 \%$ del tope de gastos de campaña establecido por el IFE para la última elección presidencial, y b)las contribuciones individuales realizadas por cada persona física o moral no pueden superar $0.5 \%$ anual del mencionado tope de gastos de campaña. Con lo anterior se pretende desincentivar las aportaciones individuales de grandes montos de dinero e incidir en la diversificación de los aportantes que tengan los partidos políticos". ${ }^{112}$

El financiamiento que recibirían los partidos políticos sería calculado con base en el tamaño del padrón electoral y el salario mínimo vigente en la capital del país. Este cálculo daría como resultado el monto a que serían acreedores los partidos. ${ }^{113}$

Por lo que respecta al tope de gastos de campaña en elecciones presidenciales quedó de la siguiente manera, el tope que es del $20 \%$ equivalente del financiamiento público de campaña establecido para todos los partidos en la elección de presidente respectiva. Para campaña de diputados el tope se fijó en el monto de gasto de campaña para la elección presidencial entre 300 que son el número de diputados que se eligen por el principio de mayoría relativa. Mientras que para las

\footnotetext{
${ }^{112}$ Córdova Vianello, Lorenzo. Ibíd. Pág. 60.

${ }^{113}$ Murayama, Ciro. "Financiamiento a los partidos políticos: el nuevo modelo mexicano". En Salazar, Pedro y Lorenzo Córdova (coord.) Estudios sobre la reforma electoral de 2007. Hacía un nuevo modelo. TEPJF. México. 2008. Pág. 267.
} 
campañas de senadores, el tope de gastos se establece al multiplicar la suma del tope de gastos de campaña para la elección de diputados por el número de distritos en entidad federativa que se trate con un límite máximo de 20 distritos por estado. ${ }^{114}$

La distribución de recursos dados a los partidos políticos con la reforma de 2007, no sufrió modificación alguna. Se mantuvo la fórmula en dónde se determinan que el $30 \%$ del monto total en partes iguales entre los partidos políticos mientras que el restante $70 \%$ por medio del porcentaje de votación que obtuvo cada partido sacó en la última votación.

\subsection{Estructura orgánica del IFE.}

El IFE se divide en tres secciones principales que conforman a esta institución y que la constituyen. Los siguientes son las áreas centrales: a) órganos centrales del instituto; b)direcciones ejecutivas; c) unidades técnicas y d)organismos desconcentrados.

\subsubsection{Partes integrantes del IFE.}

Los órganos que conforman la estructura al IFE son los siguiente: a) directivos; b) técnicos-ejecutivos; c) vigilancia.

\footnotetext{
${ }^{114}$ Córdova Vianello, Lorenzo. Opus Cit. Pág. 61.
} 
La estructura directiva dentro del IFE la integran los órganos directivos son el Consejo General y la Presidencia del Consejo General, la Junta General Ejecutiva, Secretaria Ejecutiva, Unidad de Fiscalización de los Recursos de los Partidos Políticos y la Contraloría General.

Los órganos técnicos-ejecutivos están conformadas por las Juntas Ejecutivas Locales, que se constituyen de un vocal ejecutivo y el consejo local. Mientras que en los órganos de vigilancia se encuentran las Juntas Distritales, Consejos Distritales y Mesas Directivas de Casilla.

\subsubsection{Consejo General del IFE.}

El Consejo General del IFE es el órgano superior de dirección de todo el Instituto, es el responsable de vigilar el cumplimiento de las disposiciones constitucionales y legales en materia electoral, y velar porque los principios de certeza, legalidad, independencia, imparcialidad y objetividad que guían todas las actividades de la institución. Es decir, que el Consejo General es la máxima instancia de toma de decisiones del IFE. Su actuación es menester que se sujete a los principios rectores para estar de acuerdo al mandato constitucional.

El Consejo General del IFE está constituido por un presidente consejero y ocho consejeros electorales. La duración del presidente consejero es de seis años aunque puede reelegirse un periodo más. El cargo de los consejeros electorales dura nueve años. La forma en cómo 
se eligen al Consejero presidente y a los ocho consejeros electorales es por medio del voto de dos terceras partes de la Cámara de Diputados.

También existen otros elementos que integran el Consejo General que poseen voz pero no voto. Los consejeros del Poder Legislativo que están representados por tres miembros de todo el parlamento de la Cámara de Diputados. Otros son los representantes de cada uno de los partidos políticos con reconocimiento legal. Mientras que el Secretario Ejecutivo igualmente participa en el Consejo General pero no posee voto. La elección del Secretario Ejecutivo es, a propuesta del Consejero Presidente y con dos terceras parte del Consejo General.

El Consejo General del IFE también posee seis comisiones que son de funcionamiento permanente. Estas comisiones están integradas únicamente por los Consejeros Electorales. Las Comisiones son: a)Capacitación Electoral y Educación Cívica, b) Organización Electoral, c) Prerrogativas y Partidos Políticos, d) Servicio Profesional Electoral, e)Registro Federal de Electores y f) Quejas y Denuncias.

También es importante destacar que existen otras comisiones que no son permanentes. Este tipo de comisiones sólo se conforman cuando el Consejo General lo considera necesario.

\subsubsection{Atribuciones del Consejo General del IFE.}

El artículo 109 del COFIPE le otorga al Consejo General del IFE las siguientes atribuciones: 
a) Responsable de vigilar el cumplimiento de las disposiciones constitucionales y legales en materia electoral.

b) Velar porque los principios de certeza, legalidad, independencia, imparcialidad y objetividad guíen todas las actividades del Instituto.

c) Designar a los directores ejecutivos del Instituto y al director general de la Unidad de Fiscalización;

d) Designar a los presidentes de los consejos locales y distritales;

e) Designar a los consejeros electorales de los consejos locales;

f)Resolver el otorgamiento del registro a los partidos políticos y a las agrupaciones políticas, así como sobre la pérdida del mismo;

g)Conocer y aprobar los informes que rinda la Unidad de Fiscalización de los Recursos de los Partidos Políticos; así como determinar los topes máximos de gastos de precampaña y campaña;

h)Registrar las candidaturas a Presidente de los Estados Unidos Mexicanos, senadores y diputados que presenten los partidos políticos nacionales;

i)Requerir a la Junta General Ejecutiva investigue, por los medios a su alcance, hechos que afecten de modo relevante los derechos de los partidos políticos o el proceso electoral federal;

j)Resolver los recursos de revisión que le competan; 


\subsubsection{Valores rectores del IFE.}

Los valores rectores del IFE son los siguientes: a)certeza, b)legalidad, c)independencia, d)imparcialidad y e)objetividad. Las definiciones que el IFE proporciona de estos valores son los siguientes:

a) Certeza. Todas las acciones que desempeñe el Instituto Federal Electoral estarán dotadas de veracidad, certidumbre y apego a los hechos, esto es, que los resultados de sus actividades sean completamente verificables, fidedignos y confiables.

b) Legalidad. En el ejercicio de las atribuciones y el desempeño de las funciones que tiene encomendadas, el Instituto Federal Electoral debe observar escrupulosamente el mandato constitucional que las delimita y las disposiciones legales que las reglamenta.

c) Independencia. Es la garantía y atributos de que disponen los órganos y autoridades que conforman la Institución para que sus procesos de deliberación y toma de decisiones se den con absoluta libertad y respondan única y exclusivamente al imperio de la ley, afirmándose su total independencia respecto a cualquier poder establecido.

d) Imparcialidad. En el desarrollo de sus actividades, todos los integrantes del Instituto Federal Electoral deben reconocer y velar permanentemente por el interés de la sociedad y por los valores fundamentales de la democracia, supeditando a éstos, de manera irrestricta, cualquier interés personal o preferencia política. 
e) Objetividad. Implica un quehacer institucional y personal fundado en el reconocimiento global, coherente y razonado de la realidad sobre la que se actúa y la obligación de percibir e interpretar los hechos por encima de visiones y opiniones parciales o unilaterales, máxime si éstas pueden alterar la expresión o consecuencia del quehacer institucional. ${ }^{115}$

\subsection{Unidad de Fiscalización de los Recursos de los Partidos Políticos.}

La creación de la Comisión de Fiscalización de los Recursos de los Partidos Políticos y Agrupaciones Nacionales se dio el 22 de noviembre de 1996. Esta unidad se constituyó a través de un acuerdo del Consejo General del IFE que dictaminó este punto. ${ }^{116}$ Posteriormente la Unidad de Fiscalización de los Recursos de los Partidos Políticos fue añadida a la Constitución Política de los Estados Unidos Mexicanos en el artículo 41 con base en la reforma electoral de 2007.

Esta Unidad tiene como objetivo vigilar que los ingresos y gastos de los partidos políticos cumplan con la normatividad en la materia para que los integrantes del Consejo General tengan información objetiva, veraz y oportuna para la toma de decisiones relativas a quejas y denuncias, y a los resultados globales de los procesos de fiscalización.

\footnotetext{
${ }^{115}$ http://www.ife.org.mx/portal/site/ifev2/Que_es/

${ }^{116}$ Diario Oficial de la Federación. Miércoles 30 de enero de 2008. Primera Sección. Pág. 79.
} 
La Unidad de Fiscalización revisa los informes de ingresos y gastos de los partidos políticos y candidatos que están obligados a presentar ante la autoridad. Los informes que se entregan a la Unidad son de dos tipos uno trimestral y otro anual aunque también existen los informes de precampaña y campaña. En estos reportes se presentan los ingresos que tienen procedencia de fuentes privadas -aportaciones de militantes, y simpatizantes, colectas públicas, rendimientos financieros- y los gastos relativos a rentas, sueldos, honorarios, pagos de servicio y contratos, compras de muebles e inmuebles, entre otros.

Los informes de precampaña y campaña los presentan los precandidatos y candidatos. En este tipo de documentos se hace conocer a la Unidad de Fiscalización, el monto de los ingresos de fuentes privadas -aportaciones de simpatizantes, precandidatos o candidatos- $y$ también las transferencias que se realizan de los órganos directivos de los partidos políticos hacía los precandidatos y candidatos. También se revisan los gastos de propaganda y de operación de campaña así como de la misma manera se consideran los egresos generados por el uso de los medios de comunicación impreso y en producción de materiales audiovisuales.

La Unidad de Fiscalización se conforma de la siguiente manera:

a) Dirección General de la Unidad de Fiscalización,

b) La Dirección de Auditoría de Partidos Políticos, Agrupaciones Políticas y otros.

c) La Dirección de Resoluciones y Normatividad. 
Las atribuciones que el reglamento interno de la Unidad de Fiscalización le confieren a esta parte de la Dirección son:

a) Formular las opiniones e informes que sobre asuntos propios de la Unidad de Fiscalización le solicite el Consejo, el Presidente del Consejo o el Secretario Ejecutivo;

b) Emitir las normas generales de contabilidad y registro de operaciones aplicables a los partidos políticos, a las agrupaciones políticas nacionales, a las organizaciones de ciudadanos que pretendan obtener registro como partido político, así como a las organizaciones de observadores electorales;

c) Vigilar que los recursos de los partidos tengan origen lícito y se apliquen estricta e invariablemente a las actividades

d) Proporcionar la orientación, asesoría y capacitación necesarias para el cumplimiento de la normatividad en materia de origen y aplicación de sus recursos a partidos políticos, agrupaciones políticas nacionales, organizaciones a las que pertenezcan los observadores electorales, así como organizaciones de ciudadanos que pretendan obtener registro como partido político;

e) Fiscalizar y vigilar los ingresos y gastos de los partidos políticos, de las agrupaciones políticas nacionales, de las organizaciones de ciudadanos que pretendan obtener registro como partido político, así como los de las organizaciones de observadores electorales;

f) Recibir y revisar los informes trimestrales, anuales y los de gastos de campaña que presenten los partidos políticos, así como los de gastos de precampaña que presenten sus candidatos; asimismo, los informes de ingresos 
y gastos que presenten las agrupaciones políticas nacionales, las organizaciones de ciudadanos que pretendan obtener registro como partido político, y las organizaciones a las que pertenezcan los observadores electorales;

g) Presentar para su aprobación al Consejo Electoral los proyectos de resolución respecto de la revisión de los informes de ingresos y egresos que presenten los partidos políticos, agrupaciones políticas nacionales, organizaciones a las que pertenezcan los observadores electorales, así como organizaciones de ciudadanos que pretendan obtener registro como partido político, en los que se propongan las sanciones correspondientes en caso de que se acredite la comisión de irregularidades;

h) Llevar a cabo las verificaciones a que haya lugar, dentro de la revisión de informes de ingresos y egresos que presenten los sujetos obligados conforme al Código, así como las que guarden relación con los procedimientos oficiosos y los de queja. En el mismo sentido, requerir información complementaria respecto de los diversos apartados de los informes de ingresos y egresos o documentación comprobatoria de cualquier otro aspecto vinculado a los mismos;

i) Requerir de las personas, físicas o morales, públicas o privadas, en relación con las operaciones que realicen con partidos políticos, agrupaciones políticas nacionales, organizaciones de ciudadanos que pretendan obtener registro como partido político, y organizaciones de observadores electorales;

j) Ordenar la práctica de auditorías, directamente o a través de terceros, a las finanzas de los partidos políticos; 
k) Celebrar convenios de coordinación en materia de fiscalización de los recursos de los partidos políticos con las autoridades competentes, con la aprobación del Consejo General;

m) Tramitar y dar respuesta a las solicitudes de colaboración que generen las autoridades competentes en materia de fiscalización de los recursos de los partidos políticos en las entidades federativas, en cuanto a las limitaciones de los secretos bancario, fiduciario o fiscal;

n) Remitir a la Comisión Nacional Bancaria y de Valores, al Servicio de Administración Tributaria, y a la Unidad de Inteligencia Financiera de la Secretaría de Hacienda y Crédito Público, los listados de las personas que encuadren en la definición de personas políticamente expuestas, relacionadas con la materia electoral, así como notificarles cuando éstas dejen de ostentarse con la condición o cargo que tenían.

\subsubsection{Proceso de Fiscalización de los recursos de los Partidos Políticos.}

El proceso de fiscalización de los partidos que realiza a Unidad de Fiscalización de los Recursos de los Partidos Políticos realiza la siguientes tareas que se presentan a continuación:

a) Preparación y entrega de informes. Este periodo comienza desde el momento en que termina la jornada electoral o finaliza el año, los partidos políticos poseen un plazo de sesenta días hábiles para presentar y entregar a la Unidad de Fiscalización la 
documentación e información comprobatoria de sus ingresos y gastos.

b) Revisión de los informes. Una vez recibido los informes que envían los partidos políticos, la Unidad de Fiscalización cuenta con sesenta días hábiles para revisar los informes anuales mientras que en el caso de los informes de campaña son ciento veinte días hábiles. Cuando se analiza los informes enviados por los partidos políticos, la Unidad de Fiscalización coteja los datos de esta Unidad con los expedientes con la Comisión Nacional Bancaria y de Valores, el Servicio de Administración Tributaria, la Unidad de Inteligencia Financiera de la Secretaria de Hacienda y Crédito Público y también de las personas físicas y morales que hicieron ventas, prestaron servicios o dieron aportaciones en efectivo o en especie.

c) Retroalimentación con partidos políticos y protección de su derecho de audiencia. Cuando se realizan las revisiones puede suceder que haya observaciones relativas a errores y omisiones en los informes. La Unidad de Fiscalización envía las observaciones en forma escrita a los partidos políticos que lo ameriten. A este proceso de observaciones se le llama la primera ronda de oficios. Una vez recibida la notificación, los partidos tienen un lapso de diez días hábiles para responder a estas peticiones.

Durante el transcurso de los diez días hábiles en los que la Unidad de Fiscalización espera de los partidos políticos manden su respuesta, la Unidad convoca a los responsables financieros de los partidos y a los representantes de los mismos ante el Consejo General del IFE. La 
reunión es para garantizar el derecho de audiencia. La sesión sirve para aclarar los requisitos planteados por la Unidad y dejar que los representantes de los partidos expongan sus puntos de vista acerca de los mismos.

Después de que los partidos políticos presentan sus reportes, la Unidad de Fiscalización hace una revisión y valora los documentos adicionales y la información que se les proporcionó.

Luego de la valoración de los documentos presentados por los partidos políticos y si la Unidad de Fiscalización así lo decide, existe la posibilidad de notificar por medio de una segunda ronda de oficios sobre los aspectos que se quedaron pendientes o aclaraciones que es preciso que sean respondidas en cinco días hábiles. Nuevamente se repite el proceso de derecho de audiencia por medio de una ronda para discutir con los representantes de los partidos políticos y encargados de las finanzas de los partido y la Unidad de Fiscalización.

d) Revisión final y elaboración de los documentos de resultados globales. Cuando se terminan los cinco días de la segunda ronda de oficios, la Unidad de Fiscalización tiene veinte días hábiles para presentar la revisión final del informe $\mathrm{y}$ realizar los documentos pertinentes que son del resultado final ${ }^{117}$.

Una vez que se termina el proceso de revisión de los informes presentados por los partidos políticos y después que se hayan desahogado todos los recursos que marca la ley, la Unidad de Fiscalización presenta

\footnotetext{
${ }^{117}$ El ABC de la fiscalización [a partidos políticos] http://www.ife.org.mx/docs/IFE-v2/CNCS/CNCS-IFEResponde/2013/05\%20Mayo/abcfisc/abc.pdf)
} 
el dictamen consolidado y el proyecto de resolución. En el dictamen consolidado se muestra la información acerca de las observaciones detectadas y dónde se hace una especificación de cuáles fueron aclaradas total o parcialmente y cuáles no. También el dictamen consolidado contiene la manera en cómo se notificaron las observaciones como de igual forma el contenido de las respuestas de los partidos políticos.

El proyecto de resolución es donde se plasman los razonamientos jurídicos en torno a los incumplimientos de los partidos políticos, precandidatos y candidatos. Con base a esta dos documentos que presenta la Unidad de Fiscalización, se establecen sanciones a los partidos políticos que infringen la ley.

Dependiendo de la gravedad de la falta cometida por los partidos políticos, éstos pueden hacerse acreedores a sanciones que van de amonestaciones públicas, multas, hasta la pérdida de registro. En dado caso que los partidos consideren que se violó algún derecho, tienen la posibilidad de impugnar ante el Tribunal Electoral del Poder Judicial de la Federación.

Las multas que impone el Consejo General del IFE ante los documentos presentados por la Unidad de Fiscalización recaen sobre los partidos políticos y no sobre los candidatos o precandidatos. Los partidos que se hacen acreedores de las multas se descuentan de las cantidades que periódicamente se entregan a los candidatos.

Las sanciones que tienen que ver con los incumplimientos en materia de fiscalización se entregan a la Tesorería de la Federación que 
depende de la Secretaria de Hacienda y Crédito Público. El dinero de estas multas por ley es transferido al Consejo Nacional de Ciencia y Tecnología para que cubra los gastos que genera su accionar.

\subsection{Conclusiones.}

En este capítulo se estudió el proceso histórico que se siguió para llegar al modelo de fiscalización que priva hasta el momento. Fueron varios las acontecimientos que se presentaron para arribar a este tipo de fiscalización. Se pueden dividir en factores internos y externos.

Los internos son la participación de la sociedad civil mexicana por medio de manifestaciones de grupos organizados. Otro de los aspectos que jugaron un papel clave fue los puestos que ganaron los partidos políticos de oposición (PAN, PRD) en el congreso y en los órganos de decisión electoral a lo largo de varias décadas.

Las quejas e inequidades por parte de los partidos de oposición en la elección presidencial de 1994 en la contienda electoral fueron otro factor que movió hacia un cambio en el ámbito del financiamiento y fiscalización de los recursos de los partidos políticos. Además de la participación de privados con cuantiosas sumas. 
En cuanto a los factores externos, se tenía el propósito de evitar el flujo de dinero proveniente de actividades ilícitas pudiera afectar el curso de la contienda electoral.

El Consejo General del IFE cuenta con los elementos jurídicos y técnicos adecuados para realizar sus funciones. Se apoya en direcciones que cuentan con personal calificado para llevar a cabo sus encomiendas. El Consejo General del IFE ha logrado consolidarse a partir de las reformas de 1996 como un garante de las decisiones políticas del país. Además que continúa siendo la institución electoral clave para realizar las elecciones presidenciales y de diputados y senadores.

Aunque ha existido un avance en las atribuciones y actuación del Consejo General y de la Unidad de Fiscalización del IFE, sin embargo se han presentado casos como el de Monex que sugieren que aún existe aspectos institucionales y humanos que dejan duda acerca del avance sustantivo del instituto.

Los avances que se han realizado en materia de fiscalización electoral en México son varios. La creación de la Unidad de Fiscalización con su autonomía técnica es un progreso en la fiscalización electoral debido a que está conformada por profesionales. También la legislación electoral que fue plasmada en el COFIPE para que exista la colaboración con otras entidades gubernamentales para verificar a personas físicas y morales y sus relación con los partidos políticos.

Las vulnerabilidades que se pueden encontrar en el modelo de fiscalización en México también son varias. Aunque los avances son valiosos en este rubro, sin embargo la poca coordinación institucional y 
las omisiones que en el actuar de éstas en su trabajo conjunto con la Unidad de Fiscalización provocan distorsiones. Otra fragilidad del modelo de fiscalización electoral es que los partidos políticos y sus representantes procuren hallar huecos en la legislación y utilizarlos a su favor o emitiendo componendas legales que perjudiquen el proceso de inspección electoral.

Otra posible debilidad del modelo de fiscalización es que las autoridades de la Unidad de Fiscalización no tengan los elementos suficientes tanto jurídicos como técnicos para realizar su labor. Dentro de los aspectos legales existe la poca posibilidad con la técnica jurídica actual de probar ciertos delitos. El procedimiento jurídico precisa de documentación para probar determinados delitos. Cuando se cometen ciertos crímenes no dejan ningún papel y por lo tanto es imposible probarlos con un escrito que no existe.

Por tanto, es preciso que el método jurídico use otros elementos como declaraciones de implicados para dar sentido y profundidad a la investigación.

En el ámbito técnico de la contabilidad, el modelo de fiscalización electoral procura abarcar sólo los rubros de competencia que le corresponde. Es decir, los atributos del reglamento interno de la Unidad de Fiscalización permite la creación de las normas generales de contabilidad y registro de operaciones aplicables a los partidos políticos.

Esto es una violación en la contabilidad debido a que existe una la Comisión de Principios de Contabilidad de México que establece los lineamientos de contabilidad que están de acuerdo con el Comité 
Internacional de Principios de Contabilidad. Por tanto, no es adecuado que la Unidad invente una nueva norma general de contabilidad porque funciona una norma general de contabilidad aprobada por varias instituciones nacionales e internacionales. Este hecho se presta a sospechas. 


\title{
Capítulo 3. El principio de imparcialidad en las elecciones presidenciales de 2012.
}

\begin{abstract}
3.1.-Introducción.
El presente capítulo hace una revisión del caso Monex que es el objeto de este capítulo, también que se analizará por qué la forma en cómo se designa a los consejeros electorales repercute en la imparcialidad del Consejo General del IFE. El análisis de los argumentos brindados por los integrantes del Consejo General y de los representantes de los partidos políticos así como de los consejeros del Poder Legislativo en la sesión general del consejo general del IFE del día 23 de enero de 2013 ayudarán a comprobar si el principio de imparcialidad que es un valor rector en el actuar de la institución, se cumplió. La pregunta que guiará el desarrollo de este tercer capítulo será la siguiente: ¿el Consejo General del IFE vulneró el principio imparcial en la resolución del caso Monex?.
\end{abstract}

\subsection{Transición a la democracia en México.}

La transición mexicana a la democracia fue un proceso lento que fue desencadenado por los cambios sociales, políticos y económicos que acontecieron en el país desde la década de los 70's del siglo pasado. El PRI que fue el partido- gobierno tuvo un papel central en el sistema político mexicano. En el transcurso de las décadas el PRI fue perdiendo su 
lugar hegemónico en el sistema, y otros partidos políticos tuvieron presencia en las gubernaturas de los estados de la república mexicana. La transformación del régimen se inició con la presencia de partidos rivales al PRI en los municipios, para después ganar gubernaturas y congresos locales, para finalmente llegar a obtener la presidencia de la república en el año 2000 cuando el candidato del PAN Vicente Fox obtuvo ese cargo.

Los pilares que tuvieron vigencia en el sistema político mexicano desde 1940 a 1988 fueron el presidencialismo, la existencia de un partido hegemónico (PRI) y las elecciones no competitivas $^{118} \mathrm{y}$ el corporativismo. Sin embargo, el proceso de transformaciones en materia electoral fue un elemento clave en el proceso de apertura democrática del país. La reforma electoral de 1977 se caracterizó por procurar la liberalización política a través de una apertura paulatina para sectores que buscaban participar en la vida política.

Una serie de reformas en el rubro político-electoral 1977, 1986, 1991, 1996 y 2007 fueron pilares para el impulso de la apertura política en el país. Es pertinente transcribir el argumento que menciona César Cansino acerca de la característica que tuvo la apertura democrática en México. "La apertura política [...] debe ser entendida como un proceso a través del cual el Estado ha venido concediendo gradualmente algunos derechos políticos y civiles en dirección democrática, pero en una línea de organización controlada de la sociedad civil sea a nivel de élites que de

\footnotetext{
${ }^{118}$ Véase. Ayala Camargo, María Guadalupe. Los partidos políticos en la transición a la democracia en México, 1997-2000. Tesis de Maestría. Facultad de Ciencias Políticas y Sociales. UNAM. México. 2002. Pág. 29.
} 
masas, y a través del cual se buscan conservar o incrementar las bases de legitimidad del régimen". ${ }^{119}$

Coincidiendo con la propuesta que hace Mauricio Merino acerca del proceso de transición que experimentó el país, se puede decir que:

"en lugar de ser una transición pactada, la mexicana ha sido [...] una transición votada; además no ha habido una ruptura con el régimen anterior, sino que por el contrario, el cambio se ha basado en la apertura gradual y continua; por último, en vez de una transformación de las reglas del juego, lo que ha ocurrido ha sido la recuperación de las instituciones ya existentes."120

Estas dos reflexiones que hicieron César Cansino y Mauricio Merino acerca del proceso de transformación y apertura política que experimentó el país son importantes porque describen de forma precisa los elementos clave que tuvo la transición mexicana. Retomando los argumentos presentados anteriormente, los partidos de oposición jugaron un papel protagónico dentro de la transición a la democracia. El caso del PAN fue notable debido a que en dos momentos esenciales participó para forzar cambios dentro de la política mexicana. El primer fue la elección estatal en Chihuahua en 1983 y cuando ganó la presidencia de la república en el 2000.

La elección en el estado de Chihuahua fue donde el PAN inició una lucha social en contra del fraude electoral. Para Lorenzo Meyer el caso de Chihuahua se adelantó a lo que fue la elección presidencial de 1988.

\footnotetext{
${ }^{119}$ Cansino, César. La Transición mexicana, 1977-2000. $1^{\circ}$ Edición. Centro de Estudios en Política Comparada. México. 2000. Pág. 84.

${ }^{120}$ Merino, Mauricio. La transición votada. Crítica a la interpretación del cambio político en México. $1^{\circ}$ Edición. FCE. México. 2003. Pág. 15.
} 
La rebelión electoral después del fraude de 1983 en ese estado, el mismo fraude, la derrota electoral del PRI en Chihuahua y en 1998 el PRI regresó a la gubernatura de Chihuahua por la vía electoral ${ }^{121}$ fueron aspectos que se volverían a repetirse en la elección presidencial de 1988 y posteriormente en el 2000 pero esta vez a nivel nacional.

En la elección presidencial de 1988, el candidato del PRI Carlos Salinas de Gortari ganó la elección. Un suceso que marcó esa contienda presidencial fue que el sistema de conteo de votos "se cayó". Sin embargo el Frente Democrático Nacional que encabezó Cuauhtémoc Cárdenas se quejó de fraude. Las movilizaciones que se realizaron después de dicho suceso, marcaron un hito en la historia política del país, porque se notó que una parte de los ciudadanos estaban dispuestos a defender sus derechos políticos.

Para el año de 1989, fue la primera vez que el PRI reconoció la victoria de un partido de oposición en una gubernatura. Baja California fue el primer estado que experimentó una alternancia en el poder. Este triunfo de la oposición, fue provocada por el clima de tensión que se había vivido después del fraude electoral en Chihuahua de 1983 y el fraude presidencial de 1988, así como al apoyo recibido por el PRI de parte del PAN, para realizar algunas reformas políticas en la Cámara de Diputados.

Esta inconformidad electoral que se presentó en diversos estados de la república fue un factor que conformó la alianza de los partidos de

\footnotetext{
${ }^{121}$ Véase. Meyer, Lorenzo. El Estado en busca del ciudadano. Editorial Oceano. México. 2005. Pág. 57.
} 
oposición para exigir al PRI que sus demandas de mayor justicia electoral se vieran plasmados en las leyes electorales. Después de cada elección y de los conflictos post electorales, los partidos políticos de oposición apelaban a la opinión pública para hacer eco de sus demandas de tener un árbitro y leyes electorales que fueran imparciales. Esta acción provocó que los ciudadanos también presionaran a las administraciones públicas priístas para hacer modificaciones electorales. El suceso clave de la transición a la política en México, fue la reforma electoral de 1996.

La reforma electoral de 1996 hizo que el IFE tuviera completa autonomía en su funcionamiento. El anhelado deseo de los partidos de oposición de que el IFE fuera imparcial se vio plasmado en esa reforma. La elección de los consejeros ciudadanos para el Consejo General del IFE y la salida del Secretario de Gobernación fue un cambio trascendente en la estructura interna de la institución. La transformación conjunta del recambio partidista en las gubernaturas en el interior del país y la autonomía del IFE fueron los sucesos que propiciaron la transición democrática. Además que la competencia partidista fue el factor clave que favoreció el dinamismo del sistema de partidos mientras que el IFE fue la institución electoral que dio cauce a la competencia partidista.

También es importante mencionar que la reforma de 1996 tuvo la intención de atenuar la inequidad de los recursos dados de los partidos en la contienda electoral. Las declaraciones del presidente Ernesto Zedillo que realizó en un viaje al extranjero dan constancia de que el presidente sabía que las elecciones presidenciales de 1994 fueron 
inequitativas para los partidos de oposición. Por tanto, la reforma tuvo como objetivo poner condiciones más parejas de competencia entre los partidos políticos en el rubro de recursos federales que recibían los mismos. Esta acción se vio reflejada en el aumento de los recursos así como en el acceso de los partidos políticos a los medios de comunicación.

Las elecciones intermedias de 1997 fueron un momento clave que mostraban lo que sucedió tres años después en la elección presidencial del 2000. Se conjugaron una serie de factores que hicieron que el PRI dejara de tener mayoría en la Cámara de Diputados y que se plasmara la fuerza de la oposición en distintos cargos de elección popular. El recuento de esta elección se puede resumir en que "la elección de 1997 fue el resultado de una acumulación de sucesos políticos que fue sumando fuerza opositora, de mejores reglas del juego, de un desgaste del gobierno, de un descrédito del partido oficial y de una decisión ciudadana que finalmente pudo protagonizar unos comicios limpios". ${ }^{122}$

El resultado de la reforma electoral de 1996 al IFE fue la pérdida del PRI en las elecciones intermedias de la mayoría en la Cámara de Diputados. Además de que el PRI perdió las primeras elecciones democráticas para elegir al Jefe de gobierno del DF ante el PRD.

Para la campaña presidencial de año 2000, la dinámica electoral siguió su cauce de transición a la democracia. La campaña presidencial del panista Vicente Fox en 2000, logró conjuntar una serie de factores que le dieron

\footnotetext{
${ }^{122}$ Aziz, Alberto y Jorge Alonso. "Votos, reglas y partidos". En Aziz Nassif, Alberto (Coord.) México al inicio del siglo XXI. Democracia, ciudadanía y desarrollo. $1^{\circ}$ Edición. CIESAS-Miguel Ángel Porrúa. México. 2003. Pág. 73.
} 
la victoria en la contienda presidencial. "A través de una hábil campaña, sobre todo mediática, la coalición organizada en torno a su candidatura pronto pudo capitalizar a su favor el resentimiento y hartazgo casi fóbicos que habían producidos no sólo setenta años de priísmo, sino, ante todo, el malestar generado por tres sexenios de crisis, de adversidades y de fracasos". ${ }^{123}$ Es importante mencionar que antes de la elección presidencial del 2000, el PRI venía en un proceso de inestabilidad dentro del partido y pérdida de legitimidad. Esas dos características hicieron que este partido tuviera un desempeño electoral menor al registrado en otras elecciones.

Los elementos políticos que precisaba modificar el presidente Vicente Fox en su sexenio para cambiar el antiguo régimen priísta era "la voluntad de la clase política en el poder [...] para dejar atrás el viejo régimen político; acuerdos legislativos en el Congreso de la Unión para impulsar la reforma democrática del Estado; desmantelamiento de los pilares del sistema anterior sin caer en la refuncionalización de los mismos". ${ }^{124}$ Sin embargo, Fox continuó con las antiguas prácticas del priísmo.

Una crítica que ayuda a entender el fenómeno de la transición democrática del país fue hecha por Luis Salazar. Este autor recuerda que "la identificación del PRI y sus victorias con el autoritarismo, y del PAN y el PRD y sus triunfos con la democracia fue sin dudas un

\footnotetext{
${ }^{123}$ Attili Cardamone, Antonella y Luis Salazar. Más allá de la transición. Los cambios políticos en México. 1977-2008. UAM-Iztapalapa-Miguel Ángel Porrúa. México. 2010. Pág.143.

${ }^{124}$ Garavito, Rosa Albina. "La raquítica democracia mexicana o ¿dónde estamos en la transición?. En Anguiano Arturo (Coord.) Después del 2 de julio ¿dónde quedó la transición?. Una visión desde la izquierda. UAM-X. México. 2001. Pág. 21.
} 
ingrediente ideológico esencial en las luchas". ${ }^{125}$ Salazar hace énfasis en que es preciso tener en cuenta que la transición democrática que experimentó el país fue por causa de los procesos electorales y no por la llegada de un partido opositor a la presidencia en el año 2000.

Después del sexenio del presidente Vicente Fox, la elección presidencial de 2006 fue un suceso que marcó la historia política del país, el ex jefe de gobierno del DF, Andrés Manuel López Obrador, estaba muy bien posicionado en la opinión pública y aspiraba a contender por la presidencia de la república por el PRD. Sin embargo, PAN y PRI trataron de impedir que el ex jefe de gobierno pudiera competir en la contienda porque sabían que tenía amplias posibilidades de ganar la presidencia.

Se acusó de desacato a López Obrador por no obedecer una orden judicial que mandaba detener una obra pública en un predio particular. "El caso se revistió de un discurso de legalidad y [E]stado de derecho, que no pudo ser más desafortunado, porque desde el inicio se supo que se trataba de una maniobra política para sacar de la competencia por la Presidencia de 2006 a uno de sus principales actores."

Se desaforó a López Obrador pero la fianza que tenía que pagar por dicho cargo, fue liquidada por asambleistas panistas. Andrés Manuel López salió fortalecido de este acto y su credibilidad aumentó. Cuando llegó el momento de las campañas presidenciales, los candidatos eran Andrés Manuel López Obrador del PRD y PT y Convergencia, Felipe

\footnotetext{
${ }^{125}$ Attili Cardamone, Antonella.Opus Cit. Pág. 132.

${ }^{126}$ Aziz Nassif, Alberto y Jorge Alonso. México una democracia vulnerada. $1^{\circ}$ Edición.CIESAS-Miguel Ángel Porrúa, México. 2009.Pág. 240.
} 
Calderón del PAN y Roberto Madrazo del PRI y PVEM. Al inicio de la campaña presidencial, las encuestas ponían al candidato del PRD como el puntero en las encuestas y en segundo lugar al aspirante del PAN a la presidencia.

Ante la desventaja que tenía el Felipe Calderón, el equipo de campaña del panista lanzó una campaña de spots en radio y televisión donde denigraba y atacaba al candidato del PRD. Esta "guerra sucia" estuvo marcada por descalificaciones a Andrés Manuel López Obrador tales como "intolerante", "López Obrador es un peligro para México". También es preciso mencionar que el aspirante perredista cometió errores en su estrategia que le hicieron perder puntos en las preferencias de los votantes ${ }^{127}$. El presidente Vicente Fox tuvo una participación activa en apoyo del Felipe Calderón y junto con el Consejo Coordinador Empresarial difundieron su respaldo al representante panista en comerciales televisivos. Estos actos no fueron sancionados por el Consejo General del IFE. Otra instancia, el Tribunal Electoral del Poder Judicial de la Federación (TEPJF) una vez que terminó el proceso presidencial indicó que el ex presidente Fox había violado la ley, sin embargo no se castigó este delito.

La sociedad mexicana quedó dividida y polarizada por este acontecimiento. Un aspecto que se puede señalar del este proceso del electoral presidencial de 2006, fue que el IFE actuó de manera poco

\footnotetext{
${ }^{127}$ La diferencia en intención de voto en los primeros meses de campaña entre Andrés Manuel y Felipe Calderón era de $10 \%$. Es decir, López Obrador tenía el $40 \%$ y Calderón el 30\%. El día de la elección cambió la diferencia. Los datos del IFE daban a López Obrador y Felipe Calderón $36.36 \%$ para el primero y $36.96 \%$ para el segundo.
} 
firme en el momento de hacer cumplir la ley. El momento era clave para frenar la espiral de irregularidades y violaciones a la normatividad. El posicionamiento del Consejo General del IFE no estuvo a la altura que se requería en la elección presidencial de 2006.

Para concluir con el presente apartado, es menester mencionar que el IFE jugó un papel importante en el proceso de transición democrática. Sin embargo, a partir de la última década, los principales partidos políticos han generado que el IFE pierda credibilidad y fuerzas debido a los proyectos políticos que han tratado de imponer a esta institución. En lugar de permitir la consolidación del IFE como un órgano independiente e imparcial, esta institución se ha convertido en el campo de lucha de los partidos políticos. El siguiente apartado revisa esta característica.

\subsection{Batallas en torno a la conformación del Consejo General del IFE en 2003, 2008 y 2010.}

Las diversas reformas electorales que tuvieron lugar en el país hicieron que la Comisión Federal de Vigilancia Electoral que fue creada en 1951 llegara a ser el Instituto Federal Electoral de la reforma de 1990. Esta institución vivió un proceso de transformación electoral que dio los resultados esperados por los partidos y ciudadanos.

Un aspecto que es importante destacar es que el IFE tuvo un alto nivel de confianza antes y después de la elección presidencial del 2 de 
julio del 2000, por parte de los ciudadanos y los partidos políticos. Este hecho fue posible porque existió un consenso entre los tres principales partidos para promover a los consejeros ciudadanos que estarían al frente del IFE y que deberían tener una independencia de los partidos que los habían nombrado.

Los consejeros que se habían nombrado en 1996 para el Consejo General del IFE en la Cámara de Diputados, fueron como consejero presidente José Woldenberg, y como consejeros ciudadanos José Barragán, Alonso Lujambio, Mauricio Merino, Jacqueline Peschard, Juan Molinar, Jesús Cantú, Jaime Cárdenas y Emilio Zebadúa. También es importante mencionar que los consejeros suplentes fueron: Gastón Luken Garza, José Florencio Fernández Santillán, Fernando Serrano Migallón, Rosa María de la Peña García, Joel Ortega Juárez, Leonardo Valdés Zurita y José Francisco De Andrea Sánchez. ${ }^{128}$

A pesar de que estos consejeros fueron propuestos por un consenso entre las tres fuerzas políticas principales PRI, PAN y PRD; el IFE actuó con profesionalismo y ejerciendo sus funciones como organismo autónomo en la realización de las elecciones presidenciales y para las contiendas electorales de diputados y senadores. Esta primera generación de consejeros ciudadanos después de la reforma de 1996, poseían un perfil académico apropiado y una reputación moral adecuada para ejercer el cargo.

\footnotetext{
${ }^{128}$ Torres González, Ana María. El tránsito de las reformas electorales en México: de la Comisión Federal Electoral al Instituto Federal Electoral (1946-2007). Tesis de Maestría. Facultad de Ciencias Políticas y Sociales. UNAM. México. 2011. Pág. 141.
} 
El acuerdo implícito que tuvo un efecto positivo de confianza para la conformación del Consejo General del IFE, fue el resultado de que el PRI, PAN y PRD tuvieron un consenso de procurar una institución imparcial y propia para la democracia mexicana. La razón de tal situación fue que "la convergencia entre los consejeros giró sobre al ámbito electoral puesto que provenían del ámbito académico". ${ }^{129}$ Por tal motivo, la unanimidad fue más fuerte que las diferencias.

La llamada "ciudadanización" del IFE fue un hecho consumado. Los consejeros ciudadanos eran parte esencial del funcionamiento de la democracia mexicana. Debido a que actuaban de manera autónoma, sin presión de los partidos políticos, José Woldenberg escribió los aspectos que conlleva la imparcialidad y que es preciso retomar, "la idea fundamental es que los consejeros electorales electos por la Cámara de Diputados, capaces de ver por el conjunto y no por alguna de las partes, actuando apegados a la ley y no por presiones políticas, situados por encima de los partidos y no alineados a ellos, podrían dar garantías de imparcialidad". 130

Un momento que mostró la solidez institucional del IFE fue la decisión que tomó el Consejo General cuando impuso cuantiosas multas al PRI y al PAN por el financiamiento ilegal que habían recibido por parte del sindicato del PEMEX que era encabezado por Carlos Romero Deschamps (PRI) y la asociación Amigos de Fox (PAN). La multa al

\footnotetext{
${ }^{129}$ Díaz Sandoval, Mariela. Las disputas discursivas a favor de la democracia en los órganos autónomos: un análisis del Banco de México y del Instituto Federal Electoral. Tesis de doctorado. FLACSO México. México 2011. Pág. 191.

${ }^{130}$ Woldenberg, José. "La ciudadanización del IFE”. En Centro para el Desarrollo Democrático (Coord). Instituto Federal Electoral 20 años. CDD. México. 2010. Pág. 170.
} 
PRI por el caso de PEMEX fue de mil millones de pesos, mientras que para el PAN la sanción por el financiamiento ilegal de Amigos de Fox fue de 497 millones de pesos. Roberto Madrazo descalificó la decisión del IFE y amenazó con interponer juicio político contra los consejeros José Woldenberg y Alonso Lujambio. Las declaraciones de Madrazo mostraron el desagrado del veredicto del IFE con autonomía.

Por tal motivo, los partidos políticos afectados por las cuantiosas multas, decidieron en la próxima renovación de consejeros con un perfil personal modesto y que fuera acorde a sus necesidades partidista. El objetivo era reblandecer institucionalmente al Consejo General del IFE para evitar que fuera muy autónomo en sus decisiones y esa misma autonomía estuviera fuera del control de los partidos.

Debido a lo anteriormente mencionado, la renovación de los consejeros ciudadanos del Consejo General del IFE para el 2003 fue un punto decisivo para el posterior rumbo que siguió el Consejo General. El recambio del Consejo General en el 2003 se hizo por medio de cuotas partidistas. Se trató de privilegiar los vínculos y lealtades partidistas de los consejeros a la capacidad técnica y académica del postulante. ${ }^{131}$

Un aspecto jurídico que fue importante en la renovación del consejo general del IFE, en que las propuestas del PRD para consejeros al cargo fueron rechazadas por PAN y PRI por la razón de que el artículo 41 de la Constitución no hablaba nada acerca de la reelección de los

\footnotetext{
${ }^{131}$ Véase. Díaz Sandoval, Mariela. Ibíd.Pág. 193.
} 
consejeros. Las candidaturas que presentó el PRD eran Cantú, Alonso Lujambio, Jaqueline Peschard y Mauricio Merino ${ }^{132}$ para reelegirlos.

Los consejeros ciudadanos se eligieron en la Cámara de Diputados el 31 de octubre de 2003. Las negociaciones las realizaron la Secretaria General del PRI, Elba Esther Gordillo y el presidente Vicente Fox dieron el resultado de un IFE partidizado. El PAN prefirió ayudar al PRI a tener mayoría en el IFE a cambio de que las reformas estructurales que estaba impulsando el presidente Fox se llevaron adelante. ${ }^{133}$ Sin embargo, el PRI no apoyó al PAN en su proyecto, pero si ganó la mayoría dentro del Consejo General del IFE. El proyecto político del PRI para el IFE se impuso sobre la imparcialidad.

Los consejeros que fueron electos para suceder a sus anteriores colegas eran: Luis Carlos Ugalde como consejero presidente, Virgilio Andrade, Lourdes López, Marco Antonio Gómez, Alejandra Latapí, Andrés Albo, Arturo Sánchez, Rodrigo Morales y Teresa Núñez. Los primeros cinco consejeros fueron propuestos por el PRI y los último cuatro por el PAN. En esta ocasión el PAN y el PRI impusieron sus candidatos al consejo general del IFE para conformar una institución que generó recelo en las elecciones presidenciales de 2006. La partidización del consejo general del IFE fue un hecho.

Para Eduardo Huchim, ex consejero del Instituto Electoral del Distrito Federal, las cuotas partidistas han provocado que la elección de los miembros del Consejo General del IFE haya cambiado. Desde una

\footnotetext{
${ }^{132}$ Jaramillo Navarrete, Daniela Gisell. El cambio de integrantes del consejo general del IFE 2003.Tesina de licenciatura. UAM-I. México. 2004. Pág. 83.

${ }^{133}$ Véase. Aziz Nassif, Alberto y Jorge Alonso. México una democracia vulnerada. $1^{\circ}$ Edición.CIESASMiguel Ángel Porrúa, México. 2009.Pág. 171.
} 
elección donde reinó el aspecto académico hasta una partidista donde las lealtades fueron los elementos clave de la designación de los consejeros. "En 1996 los diputados levantaron la mira y privilegiaron las virtudes y aptitudes de los candidatos, aun sin dejar de tener presentes las filias y fobias" mientras que "siete años después, en 2003, se variaron los criterios, se bajó la mira y se integró un órganos superior de dirección menos sólido que el de 1996, encabezado por Luis Carlos Ugalde". ${ }^{134}$

Pero en el sistema partidista la situación fue diferente. La lucha por el poder entre los diversos partidos creó un clima de polarización y enfrentamiento. La elección presidencial de 2006 marcó un punto nodal en la reciente democracia. Los anuncios televisivos difamatorios que lanzó el equipo de campaña del candidato panista Felipe Calderón en contra de su competidor más cercano, Andrés Manuel López Obrador tuvieron un efecto en el electorado. Ese hecho generó que hubiera una exacerbación entre los votantes que apoyaban al candidato perredista y los que estaban a favor de Felipe Calderón. Ante tal situación, al IFE se le cuestionó su falta de firmeza para cumplir su papel como institución electoral para sancionar acciones fuera de la ley.

Estos acontecimientos han generado que "después de haber alcanzado altos grados de credibilidad institucional, sobre todo en las organizaciones de arbitrar la lucha por el poder, se les empezó a golpear desde dentro, porque fueron los propios partidos lo que vulneraron la autonomía y

\footnotetext{
${ }^{134}$ Huchim, Eduardo. "Elecciones: avances, fallas y simulación”. En Rodríguez Araujo, Octavio (Coord.) México ¿nuevo régimen político? Siglo XXI Editores. Mexico. 2009. Pág. 172.
} 
violentaron las reglas del juego."135 También es importante destacar que Alberto Aziz menciona un aspecto que se debe de rescatar y que "se puede decir que la alternancia en México se ha desarrollado sin un pacto político, salvo los acuerdos que se hicieron en materia electoral. Sin pacto no hay proyecto." 136

La reforma electoral que se presentó en el 2007 fue un momento clave para el IFE porque permitió subsanar los problemas de la elección presidencial de 2006. Las negociaciones que se presentaron entre los tres principales partidos políticos para su aprobación estuvieron vinculadas a la renovación anticipada del Consejo General del IFE. El PAN se oponía mientras que el PRD y el PRI estaban a favor. Estos dos partidos se unieron para retirar a los consejeros electorales que según su versión habían actuado de forma parcial. La designación debía terminar en diciembre de 2007, sin embargo PAN, PRI y PRD no lograron un pronto acuerdo y fue hasta febrero de 2008 que nombraron a los consejeros que faltaban.

Tras negociaciones el PAN aceptó la renovación de los Consejeros del IFE pero exigió que no se renovaran totalmente a los consejeros sino que se realizara de forma escalonada. Los Consejeros que fueron depuestos del cargo fueron Andrés Albo Márquez, María Teresa González Luna Corvera, Rodrigo Morales Manzanares, Lourdes López Flores y Alejandra Latapí Renner. Mientras que el consejero presidente Luis Carlos Ugalde renunció al cargo. Arturo Sánchez Gutiérrez, Marco

\footnotetext{
${ }^{135}$ Aziz Nassif, Alberto. "El desencanto de una democracia incipiente". En Rodríguez Araujo, Octavio (Coord.). México ¿nuevo régimen político?. $1^{\circ}$ Edición. Siglo XXI Editores. México. 2009. Pág. 27.

${ }^{136}$ Aziz Nassif, Alberto. Opus Cit.Pág. 32.
} 
Antonio Gómez y Virgilio Andrade Martínez permanecieron en su cargo. $^{137}$

Es importante mencionar que el arribo al cargo de consejero presidente de Leonardo Valdés Zurita en 2008 fue por negociaciones entre los coordinadores de bancada del PRI Emilio Gamboa Patrón y el del PAN Héctor Larios. Aunque la fracción lopezobradorista del PRD se opuso, no logró frenar el acuerdo al que habían llegado el PRI y PAN y el PRD. ${ }^{138}$

Francisco Reveles reflexiona con respecto a la renovación de los consejeros electorales después de la reforma electoral de 2007 y menciona que "una parte de los integrantes del Consejo General fueron desplazados por nuevos integrantes, como si se tratara de un ajuste de cuentas por los sucedido en la elección presidencial."139

La renovación de los consejeros electorales del Consejo General del IFE en 2008 estuvo marcado por disputas entre los tres principales partidos políticos. La designación de los consejeros nuevamente el PRI, PAN y PRD se pusieron de acuerdo. Cada uno nombró a dos consejeros que posteriormente ocuparon el cargo. Este hecho se debió a que el PRD fue la segunda fuerza en la Cámara de Diputados, lo que le permitió negociar con los otros dos partidos y no quedar excluido de la

\footnotetext{
${ }^{137}$ Huchim, Eduardo. "Elecciones: avances, fallas y simulación”. En Rodríguez Araujo, Octavio (Coord.) México ¿nuevo régimen político? Siglo XXI Editores. Mexico. 2009. Pp. 171-172.

${ }^{138}$ Díaz Sandoval, Mariela. Las disputas discursivas a favor de la democracia en los órganos autónomos: un análisis del Banco de México y del Instituto Federal Electoral. Tesis de doctorado. FLACSO México. México 2011. Pág 236.

${ }^{139}$ Reveles Vázquez, Francisco. "Repensando el papel de los órganos electorales en el proceso de democratización de México". En López Montiel, Gustavo (Coord.). Los procesos electorales desde la perspectiva local. $1^{\circ}$ Edición. Colección Sinergia. IEDF. México. 2009.Pág. 63.
} 
negociación. El PRD junto con el PRI propuso a Leonardo Valdés y Alfredo Figueroa, el PAN a María Macaria Elizondo y Benito Nacif Hernández y el PRI a Francisco Javier Guerrero Aguirre y Marco Antonio Baños. ${ }^{140}$

Además es menester tener en cuenta que el Consejo General del IFE representa para los partidos políticos un espacio de poder preciso para sus intereses. El poder institucional junto con los altos salarios que detentan los ocupantes del Consejo General del IFE hacen que este sitio sea un lugar de disputa entre los partidos políticos. ${ }^{141}$

En la renovación de los consejeros ciudadanos del Consejo General del IFE del 2010, el proceso estuvo marcado por retrasos en los arreglos por parte de los partidos políticos. Después de que se publicó la convocatoria en septiembre de 2010, se pospuso la elección de los nuevos consejeros por la falta de acuerdo entre los partidos hasta el mes de octubre. El compromiso era que para el mes de noviembre ese mismo año se lograría el acuerdo y el nombramiento de los faltantes integrantes del Consejo General del IFE. Para abril de 2011 no se llegó a un acuerdo entre las fuerzas partidarias y por tanto se pospuso hasta septiembre con idéntico resultado. En octubre de igual forma se intentó arribar a un consenso acerca de los aspirantes a consejeros y no se logró.

\footnotetext{
${ }^{140}$ Véase.De la Cruz Carrillo, Omar. "La designación de los consejeros electorales del IFE en 2010: entre la autonomía y las cuotas partidarias". Iztapalapa. Revista de ciencias sociales y humanidades. No. 73. Año 33. Julio-Diciembre 2012. Pág. 140.

${ }^{141}$ De la Cruz Carrillo, Omar. Ibíd. Pág. 135.
} 
Sin embargo pasó un año hasta que en el mes de noviembre de 2011 otra instancia tuvo que intervenir para desatorar el proceso de selección. El Tribunal Electoral del Poder Judicial de la Federación tuvo que intervenir para hacer cumplir el mandato constitucional de completar el procesos de los consejeros electorales que faltaban designar. El 30 de noviembre de 2011 este órgano a través de la sentencia SUP-JDC$12639 / 2011^{142}$ conminó al Congreso a que cumpliera con su mandato de acompletar a los consejeros faltantes del Consejo General del IFE.

En sesión del 15 de diciembre de 2011 en la Cámara de Diputados, se nombraron a los tres consejeros que faltaban para integrar al Consejo General del IFE a pesar de que el proceso electoral para presidente de 2012 ya había comenzado. El PRD propuso a Lorenzo Córdova Vianello, el PAN a María Marván Laborde y el PRI a Sergio García Ramírez. Como se puede apreciar la disputa de los partidos políticos por nombrar a consejeros electorales afines a su causa ha sido una constante desde la renovación del consejo general del IFE en el 2003 hasta la fecha.

Se podría decir que desde una perspectiva de los jugadores con veto que "el mecanismo de nombramiento de los consejeros tiende al bloque $\mathrm{y}$ depende, para un adecuado funcionamiento del equilibrio de fuerzas partidistas, pero sobre todo depende en última instancia de los equilibrios electorales."

\footnotetext{
${ }^{142}$ Carrasco Daza, Constancio. "La integración del Consejo General del Instituto Federal Electoral. Una decisión judicial para materializar la norma constitucional". Justicia electoral. $4^{\circ}$ época. Vol. I. No. 10. Julio-Diciembre 2012. Pág. 497.

${ }^{143}$ Villafranco, Citlali. "La importancia del árbitro con jugadores de veto no cooperativos: el caso del nombramiento de Consejeros electorales del Instituto Federal Electoral".Workpaper.Pág.17. http://portales.te.gob.mx/seminario/sites/portales.te.gob.mx.seminario/files/materiales/Citlali\%20Villafranco. $\% 20$ Versi\%C3\%B3n\%20final.pdf.
} 


\subsection{Caso Monex.}

Para comenzar este apartado, es relevante mencionar que el caso Monex generó polémica en la opinión pública. El asunto Monex no fue compra de voto por parte del PRI en las elecciones presidenciales de 2012, como se pensaban al respecto. Este acontecimiento trata acerca del financiamiento que el PRI hizo de su estructura partidista en las elecciones de 2012 y manejo de recursos ilícitos.

La queja que presentó el PAN ante el IFE por el caso Monex fue el 22 de junio de 2012.El reclamo fue por financiamiento con recursos ilícitos a través del banco Monex por 701 millones 471mil 800 pesos. Estos recursos se utilizaron para el pago de la estructura piramidal del PRI que abarcaba a los representantes de casillas y operadores políticos durante el periodo de campaña. El dinero se usó, de acuerdo a la queja del PAN, en el lapso de campaña por lo que debía ser considerado como recursos de gasto de campaña y no como gasto corriente.

También el PRD presentó una serie de pruebas acerca del mismo asunto. El candidato del PRD, Andrés Manuel López Obrador hizo público ante los medios de comunicación el uso de tarjetas Monex por parte de algunos operadores políticos priístas en Villahermosa, Tabasco. ${ }^{144}$ Posteriormente a la entrega de las quejas, la Unidad de Fiscalización de

\footnotetext{
${ }^{144}$ Arteta, Itxaro. "Entregan en Tabasco monederos 'Monex lealtad"'. Reforma .México D.F. 19 de julio de 2012. Año. 19. No. 6782. Pág. 3.
} 
los Recursos de los Partidos Políticos comenzó la investigación. Promovió solicitudes a la Comisión Nacional Bancaria y de Valores y del Servicio de Administración Tributaria para profundizar en la pesquisa. La indagación duró 211 días. Después de los cuales el informe se turnó al Consejo General del IFE que en sesión extraordinaria del 23 de enero de 2013 se dio la votación y se resolvieron algunos puntos cruciales en cuanto al caso Monex.

El análisis de la Unidad de Fiscalización es el siguiente: del total de tarjetas que se investigaron, que fueron 10714 , solo 7851 estuvieron en la pesquisa. Esto fue debido a que solo esas tarjetas contaban con depósitos. Mientras que 700 de las 10714 tarjetas no correspondían al PRI y las otras 1373 tarjetas no contaban con recursos.

Las 7851 tarjetas sobre las cuáles hizo la investigación la Unidad de Fiscalización, se registraron que había 43733 operaciones. Esto es, fueron usados por la tarjetas Monex una cantidad de 57 millones 318 mil 609 pesos. $^{145}$

Otro aspecto que es relevante mencionar es la parte de la relación indirecta que tenían Monex y el PRI. Estaba mediada por diversas personas morales. Entre las cuales se encontraban empresas como Alkino Servicios y Calidad, S.A. de C.V., Comercializadora Atama S.A. de C.V. y Grupo Comercial Inizzio S.A. de C.V. Estas firmas realizaron contratos con el PRI para varios servicios.

\footnotetext{
${ }^{145}$ Unidad de Fiscalización de los Recursos de los Partidos Políticos. Resumen de la resolución por la que se desahoga el caso Monex-tarjetas. IFE. Pág.5.http://www.ife.org.mx/docs/IFE-v2/CNCS/CNCS-IFEResponde/2013/01\%20Enero/rmonex/RPRMonex.pdf.
} 
La empresa Alkino Servicios y Calidad, signó un documento con el PRI donde se obligaba a brindar recursos por un monto de 66 millones 326 mil 300 pesos. La naturaleza del contrato fue mutua. Duró del 1 de marzo de 2012 que fue el día en que firmó hasta siete meses después a partir del 1 de abril. Mientras que con Alkino Servicios y Calidad firmó un contrato mutuo, con Comercializadora Atama. Alkino le entregaba 66 millones 326mil 300 pesos a Atama para que fuera depositado en tarjetas de prepago. Este acuerdo se firmó el 15 de marzo de 2012 para un lapso de siete meses, a partir del 1 de abril. ${ }^{146}$

Posteriormente Comercializadora Atama signó el 26 de marzo de 2012 una comisión mercantil con la empresa Grupo Comercial Inizzio. La duración del contrato fue de un año a partir de la firma del mismo. En este contrato, era para la adquisición de tarjetas y la dispersión de los recursos por medio de la banca Monex. Por último, Grupo Comercial Inizzio firmó un contrato de prestación de servicio con la banca Monex el 9 de abril de 2012. Banca Monex prestó el servicio de 9924 tarjetas a Inizzio.

Respecto a los pagos que realizó el PRI por los servicios hechos por Alkino, se constata en el reporte de la Unidad de Fiscalización que se hicieron dos pagos por parte del partido a la empresa el 13 de julio de 2012 por concepto de servicios prestados y por pago de intereses. La primera emisión fue de 1 millón 682 mil 528 pesos mientras que la segunda fue por 2 millones 560 mil 525 pesos. Otras fechas de pago del PRI a Alkino fueron el 18 de julio de 2012, 23 de julio de 2012 y 9 de agosto de 2012. La primera fue por el concepto de financiamiento

\footnotetext{
${ }^{146}$ Unidad de Fiscalización de los Recursos de los Partidos Políticos. Ibíd. Pág. 6.
} 
otorgado por un monto de 15 millones de pesos, la segunda fue por el mismo concepto y la última por el mismo importe y el mismo monto que las anteriores. En total fueron 49 millones 243 mil 54 pesos.

A este respecto, es importante mencionar que en una entrevista hecha a Jesús Murillo Karam, que en la elección presidencial de 2012, quien fue el coordinador jurídico de Enrique Peña Nieto, se le cuestionó acerca de la razón de que el PRI usó intermediarios para realizar una transacción financiera, cuando el mismo partido lo hubiera podido hacer sin la mediación de ningún tercero. Jesús Murillo Karam dio un rodeo al asunto. Anterior a esta entrevista, Murillo Karam negó en reiteradas ocasiones el nexo del PRI con Monex, pero después que salió a la luz pública el caso, lo tuvo que reconocer.

También es preciso mencionar que la cuenta de Grupo Comercial Inizzio en la banca Monex concentró las cuentas de diversas personas físicas y morales. La transferencia en 43 ocasiones por el monto de 71 millones 815 mil 849 pesos. La empresa Inizzio junto con la firma Importadora y Comercializadora Efra. SA. de C.V concentraron sus cuentas que poseían en Banamex, Santander, BBVA Bancomer y Banorte. La cuenta de Banamex contaba con 3millones 689 mil 7 pesos, la de BBVA Bancomer 20 millones 251 mil 177 pesos. La cuenta de Santander era de 33 millones 199 mil 415 pesos y por último la de Banorte fue de 14 millones 676 mil 250 pesos.

A pesar de que la Unidad de Fiscalización está facultada para hacer una revisión de los recursos dados a los partidos políticos, dicho órgano encontró diversas limitaciones legales. Aunque la Unidad de Fiscalización trabajó de manera conjunta con otros organismos como el SAT, la 
Comisión Nacional Bancaria y de Valores, sin embargo el caso Monex trascendió el ámbito de fiscalización electoral y abarcó rubros en los cuales la Unidad no posee atribuciones jurídicas para actuar. Este aspecto acotó el área de búsqueda y acción de la Unidad en el caso Monex. La crítica que se le puede hacer a las otras instituciones gubernamentales que participaron en la investigación del caso Monex con la Unidad fue que debieron tener una cooperación más decidida para proceder con determinación en la aplicación de la ley y abarcar legalmente las áreas a las cuales la Unidad no tiene alcance jurídico y técnico.

En el informe la Unidad de Fiscalización admite que sus restricciones fueron en los siguientes ámbitos: a) en materia fiscal; b) materia financiera y c) materia penal. La primera es debido a que no está dentro de ámbito de acción investigar los desfases existentes entre las personas físicas y morales que sus egresos sean mayores que sus ingresos, además del posible lavado de dinero. En materia financiera fue que el incumplimiento en el reporte de operaciones inusuales, relevantes y sospechosas a las autoridades correspondientes e inconsistencias relacionadas con la prevención y detección del lavado de dinero.

Resultado de las inconsistencias y de la limitación del ámbito de acción de la Unidad de Fiscalización, las empresas involucradas en el caso Monex poseen elementos que no dejan claro su status jurídico. El Grupo Comercial Inizzio estaba conformada por dos socios que se llamaban Juan Óscar Fragoso y Ramón Paz Morales. El señor Fragoso que fue uno de los accionistas de Inizzio durante la elección presidencial de 2012, sin embargo falleció el 17 de julio de 2010. 
Mientras que Ramón Paz, es un ciudadano sin empleo fijo. ${ }^{147}$ Estos datos sugieren que existen inconsistencias en cuanto al registro legal de Inizzio y de sus accionistas.

Importadora y Comercializadora Efra tuvo una importante participación en el caso Monex debido a que aportó una cantidad a la cuenta de Monex de la campaña presidencial de Enrique Peña. Emilio Fraga Hilaire que es el dueño de Efra, fue militante priísta de 2000 a 2001, donde se reportó que hizo aportaciones económicas al partido. Su medio hermano, Gabino Fraga Peña, se desempeñó como coordinador de compromisos de campaña de Enrique Pena Nieto en el estado de Tlaxcala y también fungió como contratista del gobierno del estado de México. ${ }^{148}$ El padre de los hermanos Emilio y Gabino, es Gabino Fraga Mouret que es dueño del Grupo Abogacía Profesional (GAP).

Es interesante notar que el domicilio fiscal de Efra es el mismo de GAP. Gabino Fraga Mouret fue ex colaborador de Carlos Salinas de Gortari y de Ernesto Zedillo. ${ }^{149}$ El despacho GAP fue contratista en la administración de Arturo Montiel y Enrique Peña Nieto cuando gobernaron en el Estado de México. Participó en la liberación de derecho de vía en la construcción del circuito exterior mexiquense y en el tramo de la autopista México-Querétaro que entronca con la autopista Peñón-Texcoco.

\footnotetext{
${ }^{147}$ Baranda, Antonio. "Negocia Monex con 'fantasmas"”. Reforma. México DF. Año. 19. No. 6784. 21 de julio de 2012. Pág. 1.

${ }^{148}$ Hernández, Anabel. "Trabajan los Fraga para EPN". Reforma. México DF. Año. 19. No. 6785. 22 de julio de 2012. Pág. 4.

${ }^{149}$ Guerrero, Claudia. “Admiten nexo PRI-Efra-Monex”. Reforma.México DF. Año. 19. No. 6 783. 20 de julio de 2012. Pág. 3.
} 
El trabajo conjunto que realizaron el IFE y los institutos electorales locales no fue el adecuado. Al término de su reporte la Unidad de Fiscalización reconoce que necesitaba de la participación de los institutos electorales locales del DF y de Jalisco, debido a que porque en el caso del DF, existió un monto por 10 millones 308 mil pesos mientras que para Jalisco son 6 millones de pesos que precisaron de aclaración de su uso y procedencia.

\subsection{Valoración del caso Monex por el Consejo General del IFE.}

Para iniciar la evaluación del caso Monex por el Consejo General del IFE es preciso recordar algunas de las características que conforman a la imparcialidad. El concepto de imparcialidad implica no haya una previa toma de partido, además de que no se lesionen o beneficien ilegalmente a una parte de un conflicto. La imparcialidad también precisa que exista un tercero que sea ajeno a ambas partes. Teniendo en cuenta estos elementos que implica la imparcialidad es menester principiar el análisis.

Otra acotación que es menester precisar es que en el presente análisis se basará en el estudio de los argumentos brindados por los consejeros electorales y representantes de los partidos políticos y consejeros del poder legislativo. $^{150}$

\footnotetext{
${ }^{150}$ Por argumento se entiende "un razonamiento que se emplea para probar o demostrar una proposición, o bien para convencer a otro de aquello que se afirma o se niega". Fernández Ruiz, Graciela. Argumentación y lenguaje jurídico. Aplicación al análisis de una sentencia de la Suprema Corte de Justicia de la Nación. $1^{\circ}$ Edición. IIJ-UNAM. México. 2011. Pág. 8. Disponible en formato: http://biblio.juridicas.unam.mx/libros/libro.htm?l=3016
} 
Para empezar el análisis de los argumentos presentados por los consejeros ciudadanos es preciso decir que se tomaron del documento de la sesión del 23 de enero de 2013 del Consejo General del IFE. Las principales razones que proporcionan los consejeros en el momento en que hacen uso de la palabra. Después de citar la argumentación se presentará un análisis de la actuación del hablante.

\section{El consejero Mtro. Alfredo Figueroa Fernández fue el primero que} tomó la palabra después de que se presentaron los informes realizados por la Unidad de Fiscalización.

¿Qué se pudo acreditar entonces en esta lógica y circunstancia? Primero, hay que cuestionarnos si el origen de estos recursos es legal o no lo es. En este sentido, el Proyecto de Resolución señala que el origen no es ilegal desde la perspectiva electoral y no lo es porque la cuenta con la que al final del día se sufraga cada uno de estos recursos, es una cuenta que corresponde al Partido Revolucionario Institucional, devengando cada uno de esos recursos a la empresa Alkino.

A partir de ese momento, en mi opinión, hay un desvanecimiento del empleo de esos recursos y de su destino, y el Partido Revolucionario Institucional no acredita, en todos los elementos que presentó a esta autoridad, el empleo de esas tarjetas Monex, con el propósito de erogar la estructura de representantes de casilla y representantes generales que nos habría anunciado. No lo acredita y tan no lo acredita que la propia ruta de los recursos empleados en esta dirección, muestra con toda precisión que no fue el gasto que se estableció en esas entidades y que de las indagatorias y muestras que hizo la propia autoridad, acreditó que no había representantes de casilla que hubieran recibido tarjetas, que no había representantes distritales que hubieran recibido tarjetas y, por lo tanto, no puede acreditarse que para ese objeto fueron precisadas.

Por lo tanto, en este sentido y circunstancia, estaré proponiendo a este Consejo General declarar fundado el procedimiento en contra del Partido Revolucionario Institucional, por no haber acreditado el destino de estos recursos, asociados a lo que nos señaló que los emplearía. Desde luego que se trata, por la temporalidad, por la geografía y por cómo se movió el dinero, de recursos que se asocian a la campaña electoral del Partido Revolucionario Institucional en términos generales. No hay como tal la comprobación que requiere un caso como este para poder señalar que, efectivamente cada una de esas 7 mil tarjetas estuvo asociado al pago de quien se nos señaló debía hacerse.

La participación del consejero Alfredo Figueroa Fernández inició con un análisis del caso Monex, para posteriormente mencionar que en materia de fiscalización electoral no existe problema alguno. Mientras que sí reconoce que los recursos empleados no se supo dónde terminaron. La posición del consejero Alfredo Figueroa al respecto del caso Monex es de castigar al PRI, por no demostrar el destino de esos recursos. El 


\section{Mtro. Alfredo Figueroa fue propuesto por el PRD y su discurso y su sucesiva votación fue para castigar al PRI por el caso Monex.}

Posteriormente de la participación del consejero Alfredo Figueroa Fernández, tomó la palabra el consejero presidente Leonardo Valdés para agradecer y luego el representante del PAN ante el IFE cuestionó la validez del reporte de la Unidad de Fiscalización.

La primera de ellas es si el origen de estos recursos es lícito o es ilícito. Mi respuesta, la argumentaré por qué, es que el origen es ilícito. La segunda pregunta que hay que formularse aquí, ya algo ha mencionado el Consejero Electoral Alfredo Figueroa, es si el destino de estos recursos fue comprobado o no fue comprobado. Mi respuesta y argumentaré por qué, es que no ha sido comprobado. La tercera pregunta es si este recurso es electoral o no es electoral.

Estamos ante un financiamiento paralelo del Partido Revolucionario Institucional. No puedo arribar a otra conclusión, primero, porque nadie va y pide un préstamos de 66.3 millones de pesos a una empresa mercantil que, según lo que pudimos indagar y del acceso que nos dieron al expediente limitado, pero algo nos dieron de acceso, de una empresa de carácter mercantil que en su declaración fiscal del año 2011, anual, se declaró en ceros.

Estamos ante un financiamiento paralelo del Partido Revolucionario Institucional. No puedo arribar a otra conclusión, primero, porque nadie va y pide un préstamos de 66.3 millones de pesos a una empresa mercantil que, según lo que pudimos indagar y del acceso que nos dieron al expediente limitado, pero algo nos dieron de acceso, de una empresa de carácter mercantil que en su declaración fiscal del año 2011, anual, se declaró en ceros.

$\mathrm{Y}$ ¡oh! sorpresa, me dirán, bueno, claro, es que Atama fue y contrató o subcontrató a una supuesta filial que se llama Inizzio. Fíjense que Inizzio no presenta declaraciones fiscales, bueno, la Unidad de Fiscalización no las obtuvo, entre paréntesis, por eso cuestiono la exhaustividad de la investigación.

\section{Luego, Rogelio Carbajal representante del PAN ante el IFE pidió al} Secretario del Consejo que leyera el artículo 70 del Reglamento de Fiscalización.

Quiero subrayar la última parte del artículo 70 del Reglamento de Fiscalización, el titular de estas cuentas será, invariablemente, el partido político. El titular de la cuenta por la cual se dispersaron 66.3 millones de pesos a declaración de parte, es la empresa Inizzio, S.A. de C.V.

En esta intervención dijo que el origen del dinero es ilícito. El aspecto interesante de su participación es que cuestionó la trama existente acerca de la empresa Atama. Aunque el representante del PAN no entró en el punto de discusión sino que trató de mostrar que existía un financiamiento paralelo que hizo el PRI. 


\section{El consejero Marco Antonio Baños realizó unas preguntas al representantes del PAN ante el IFE.}

La primera es: Usted pidió la lectura del artículo 70 del Reglamento de Fiscalización, y ese artículo regula expresamente los ingresos en efectivo; eso no es igual a un servicio que tiene como propósito disposición de efectivo a través de los monederos, son cosas completamente diferentes. ¿Esas contrataciones se regulan por materia, por la Ley Electoral o por la Legislación Mercantil correspondiente? Ese es un punto que habría que dilucidar. ¿Cómo reporta el Partido Acción Nacional este tipo de cuestiones? Es nada más una pregunta para ir abonando en el debate y ver hasta dónde hay o no consistencia en los argumentos que va manejando la Unidad de Fiscalización.

El consejero Marco Antonio Baños le preguntó al representante del PAN acerca del rubro del derecho que regula la contrataciones con empresas. El consejero Baños se desvía del punto para que el representante del PAN aclare la tercera pregunta que le faltó por contestar.

\section{El representante del PAN argumentó lo siguiente:}

La primera pregunta del Consejero Electoral Marco Antonio Baños no es clara, porque habría que leer completo el artículo 70. Dice: "Los ingresos provenientes de fuentes de financiamiento privado, así como de los recursos que provengan del financiamiento público". Es decir, todo, no hay excepción.

En la investigación hay, dice Monex, en la investigación hay monederos a los que les fueron depositados 160 mil pesos, 200 mil, 240 mil, 47 mil 600, 50 mil, 32 mil 500, en fin, que superan evidentemente con mucho los 100 días de salario mínimo. ¿A qué voy con esto, Consejero Electoral Marco Antonio Baños? A que la labor de fiscalización seria sólo se puede hacer a través de la centralización de las cuentas y de que exista una póliza por un cheque emitido, y que esa póliza esté amparada también con una factura por la contratación de un servicio o por el pago de algún hecho.

Por eso, evidentemente aquí no se puede fiscalizar; en primer lugar, porque el dinero no ingresó y no salió de las cuentas del Partido Revolucionario Instituto.

En esta respuesta, el representante del PAN, continuó con su argumentación de la primera intervención para mostrar que existió una violación de la norma debido a que el PRI no tuvo una cuenta central (que es lo que marca la ley) y retomó el asunto de la ilegalidad del recurso.

El representante del PAN respondió a las preguntas, diciendo que la clasificación del recurso se establece como gasto electoral. Mientras que 
mencionó con respecto a la clasificación de gasto que hacen los partidos, viene sobrando porque lo importante es cómo la clasifica la Unidad de Fiscalización. No hay un aporte sustantivo por parte del consejero Baños al punto clave de la discusión.

\section{El consejero Lorenzo Córdova Vianello tomó la palabra y dio sus} argumentos acerca del caso:

Quiero articular mi intervención en tres rubros, tres rubros que coinciden en tres partes, tres partes que coinciden con la determinación de la propia litis y que sustentó el emplazamiento que se le hizo al partido político denunciado por parte de la Unidad de Fiscalización. Quiero hablar del origen, quiero hablar del destino y quiero hablar de la aplicación del gasto.

Por lo que hace al origen, efectivamente lo que se determina es un conjunto, no tanto de triangulaciones, sino si se me permite, de un sistema complejo de fondeo de las tarjetas que fueron utilizadas.

La investigación da cuenta, en la reconstrucción de esta trama, de eventuales vínculos jurídicos, comerciales o de otra naturaleza jurídica, entre estas empresas fondeadoras y la empresa subcontratada Atama. Pero, vale la pena señalar que la investigación de la Unidad de Fiscalización de los Recursos de los Partidos Políticos, no se limitó solamente a la reconstrucción de esta red de financiamiento y a la comprobación a través de acceso al Sistema Financiero Nacional de los montos precisos, las fechas exactas del fondeo de estas tarjetas, sino que también fue más allá.

Creo que vale la pena que eso se tenga, porque eso explica por qué no se continuaron las tramas de investigación, por qué se agotaron las líneas de investigación y permitiría ejemplificar por qué sí hubo un principio de exhaustividad en la determinación del origen de los recursos con los que se fondearon estas tarjetas.

De hecho, es precisamente esa investigación la que ha llevado a lo largo del proceso conducido por la Unidad de Fiscalización a comunicar presuntas irregularidades de tipo hacendario, de tipo financiero y eventualmente posibles irregularidades de tipo penal, derivadas de esa trama de financiamiento. Pero como se ha dicho en otras ocasiones en esta mesa, el Instituto Federal Electoral no es la Agencia Federal de Investigación (AFI) y el Instituto Federal Electoral no persigue ni lavado de dinero, ni persigue financiamiento del crimen organizado ni mucho menos.

\section{La participación del consejero Córdova Vianello hizo un recuento de} los elementos que hasta ese momento se sabían por medio de la información recopilada por la Unidad de Fiscalización. Aunque aclaró que al IFE no le correspondía determinar ni seguir las irregularidades legales que caen fuera de su ámbito jurisdiccional.

\section{Después de la participación del Consejero Córdova, siguió la} intervención del consejero Benito Nacif Hernández.

En primer lugar, me parece que este Proyecto de Resolución informa sobre cómo se construyó la cadena de recursos y los rastrea hasta el Partido Revolucionario Institucional. Identifica los montos, los términos de los contratos y algo que es muy importante, cuál es el propósito con el cual ese dinero se ubicó en esta cuenta concentradora. 
Desde esta cuenta concentradora también se dispersó hacia 7 mil 851 tarjetas. También eso está documentado. Se identifican aquellas tarjetas que no fueron fondeadas, pero que de alguna manera pudieron haber servido como un vehículo también para dispersar, pero queda acreditado que ahí no llegaron recursos. Asimismo, por el lado del destino, la Unidad de Fiscalización documenta lo que presenta el Partido Revolucionario Institucional respecto a cuál fue el destino de este dinero y el Partido Revolucionario Institucional nos dice que ese dinero sirvió para cumplir con obligaciones contraídas mediante la celebración de 7 mil 343 contratos de servicios personales, con enlaces territoriales, coordinadores territoriales, enlaces distritales y coordinadores distritales, obligaciones que ascendían a aproximadamente 50 millones de pesos.

El Proyecto de Resolución que nos presenta la Unidad de Fiscalización propone declarar infundados los dos agravios planteados por el quejoso. Uno, relacionado con el rebase de tope de gastos de campaña y nos dice: "Alkino monto involucrado no rebasa el límite de gastos de campaña". Asimismo el segundo agravio, que es el de un financiamiento ilegal, la Unidad de Fiscalización nos dice las obligaciones o los recursos pueden rastrearse, las cuentas del Partido Revolucionario Institucional con las cuales fueron fondeadas. Finalmente nos propone clasificar por la temporalidad en la que se ejerció el gasto, este gasto como gasto de campaña.

Me parece que todos los elementos que plantea la Unidad de Fiscalización, ciertamente no hay manera de imputar un rebase de tope de gastos, tampoco me parece un financiamiento ilegal; sin embargo, hay algunos aspectos del Proyecto de Resolución que me parece deben ser revisados, porque esos 50 millones de pesos que se destinaron para cumplir con las obligaciones, el Partido Revolucionario Institucional no aporta pruebas para relacionar las obligaciones de los contratos con las tarjetas y el dinero.

Por esa razón, propongo que declaremos fundado este Proyecto de Resolución, por la falta de no aclarar y precisar acreditando fehacientemente o con el estándar de pruebas que se requiere regularmente el destino de los recursos y que se sancione esa falta de acuerdo con los precedentes con los que contamos, que es el 150 por ciento del monto involucrado.

La intervención que realizó el consejero Benito Nacif hizo un recuento de los datos aportados por la Unidad de Fiscalización. Proporcionó un hecho paradójico porque dijo que la investigación de la Unidad rechazó las acusaciones del PRD de financiamiento ilegal y no ofreció pruebas para poder decir que hubo un rebase de topes de campaña por el PRI sin embargo mencionó que no se pudo acreditar claramente el destino de los recursos. Fue una intervención clara, equilibrada en sus argumentos.

\section{Posteriormente, continuó la participación del consejero del poder} legislativo Fernando Belauzarán.

\footnotetext{
Veamos qué es lo que pasa. Lo que tenemos es un financiamiento paralelo que esperaba ser clandestino para hacer gastos durante la campaña del Partido Revolucionario Institucional. El escándalo estalla, lo niega el Partido Revolucionario Institucional, lo niega explícitamente el Partido Revolucionario Institucional en varias ocasiones y después de transcurrida la elección lo acepta.

Pero si el Partido Revolucionario Institucional necesitaba un crédito y necesitaba 66 millones de pesos, díganme por qué va con una empresa que efectivamente no se dedica a los créditos, tiene una razón social totalmente distinta, hace gestoría y además no tiene los recursos suficientes, es como si uno quiere pedir un sushi en una pizzería, no tiene ninguna lógica. ¿Y qué hace Alkino? Que no tiene los recursos, en esta invención que crearon para tapar lo del financiamiento paralelo.
} 
¿Qué hace Alkino? Pues Alkino tampoco va a una institución crediticia, va con una empresa, incluso menos solvente que ella, porque además quien aparece como dueño de esa empresa, uno está muerto y otro es empleado de otra persona y no tiene esa capacidad financiera. Es más, no declara a la Secretaría de Hacienda y Crédito Público, no tiene trabajadores pero le piden 66 millones de pesos. La verdad es que no checa. El Partido Revolucionario Institucional acaba de pagar casi 6 millones de pesos en intereses, por 3 por ciento, cuando los intereses, si hubieran sido al 3 por ciento, hubiera sido el doble.

Es decir, esta empresa que no tenía ni siquiera para costear una nómina, ahora presta 66 millones de pesos y además a la baja de la banca comercial, es la usura a la inversa. No tiene lógica, pierdes más.

Es obvio que esto no se cumplió en el préstamo que pidió el Partido Revolucionario Institucional, pero también es obvio que está totalmente fuera del Reglamento pedir un préstamo o tener un préstamo con una Asociación Mercantil.

El Reglamento de Fiscalización es muy explícito con que los créditos se hacen con los Bancos y prohíbe la Banca de Desarrollo, pero sólo habla de la Banca Comercial para pedir créditos.

La participación del consejero del poder legislativo, Fernando Belaunzarán fue interesante debido a que expone la contradicciones que existieron del proceso. Cuestionó la lógica del asunto porque puso en evidencia que una empresa que no se dedica a prestamos los hace $\mathrm{y}$ que no tiene dinero pide dinero a otra empresa. Terminó diciendo que es ilegal porque en el reglamento de fiscalización eso es un crédito con la banca. La participación del diputado es valiosa porque pone en evidencia lo absurdo de la construcción del caso Monex.

\author{
Luego, tomó la palabra la consejera María Marván Laborde.
}

Entender cuál es el origen del dinero, entender cuál es el destino del dinero y cuál es la aplicación del mismo, así como determinar si debe o no ser gastos de campaña. En el último punto no me detendré, creo que está claro, ahí acompaño el Proyecto de Resolución, no vería la manera de sostener que esto no es gasto de campaña. Respecto al origen del dinero se nos habla de la contratación de un servicio de carácter mercantil de dispersión de dinero. Creo que aquí está el primer eufemismo y el primer eufemismo es porque con este contrato en realidad se contratan dos cosas, se contrata un esquema de financiamiento, en tanto este no recibe de manera originaria el dinero del Partido Revolucionario Institucional, sino que alguien, alguna de estas empresas pone el dinero y además se dispersa el dinero.

El análisis del mapa del dinero, complejo por cierto, nos da cuenta de que el dinero, hasta donde llega nuestra investigación, estaba en el sistema financiero, que finalmente es lo que normalmente investiga la VIF (Value Investigación Forum), pero no nos dice en qué momento el Partido Revolucionario Institucional financia ese servicio de dispersión del dinero, eso sucede hasta que paga este crédito, este financiamiento, llamémosle como le queramos llamar.

Creo que la Unidad de Fiscalización hace una serie de diligencias en las que logra revelar el mapa diseñado del dinero. Lo menos que habría que decir es que hay una obra maestra de ingeniería financiera. El ingenio revelado en este mapa está claro, lo que logra además es no aclarar el destino del dinero. Acompaño a mis compañeros los Consejeros Electorales Lorenzo Córdova, Alfredo Figueroa y Benito Nacif en las vistas que se tienen que dar, la eficiencia o no de las mismas tampoco nos toca juzgarlo en esta mesa, acompaño a mis compañeros en que sea este declarado gasto de campaña y que deba declararse fundado en lo que hace a la aplicación del dinero.

Creo que el argumento del Consejero Electoral Lorenzo Córdova, respecto al contrato como prueba de la aplicación última del dinero, es pertinente, especialmente en este caso, que el contrato dispersa efectivo, para todo efecto práctico las tarjetas de débito son efectivo. 
La consejera María Marván dijo que existió un financiamiento de un privado, posteriormente mencionó que se desconoce el destino de los recursos. Marván apoyó que esos recursos debían ser sumados como gastos de campaña. Por último, puso el tema de la equidad sobre la mesa de que no hubo equidad en los recursos por el financiamiento paralelo. Si intervención fue al punto medular del asunto.

Luego de la intervención de la consejera María Marván Laborde, el consejero Marco Antonio Baños Martínez habló:

El tema central es que cuando se ha informado sobre el tema de los recursos dispersados a través del tema Monex o del sistema contratado por vía de Monex, el Partido Revolucionario Institucional lo ha clasificado como gasto ordinario. Evidentemente ese argumento ha sido revisado, ha sido analizado en una perspectiva diferente por la Unidad de Fiscalización y en eso tenemos coincidencia con esa Unidad.

Hay argumentos para sostener que en vez de tratarse de recursos de gasto ordinario, deben ser considerados como de gastos de campaña y esa consistencia tendremos que verla con el resto de los informes que se presentarán respecto de los demás partidos políticos. Hasta ahí no tenemos ningún problema, pero ¿A dónde quiero llegar?

Que lo que ha ocurrido con la reclasificación del gasto es, en rigor, un acto de autoridad que ha reclasificado el gasto del Partido Revolucionario Institucional y lo ha sumado a gastos de campaña y no a gastos ordinarios. Entonces, ¿Cómo solicitar esa comprobación? En rigor la autoridad la que ha determinado que se gastó de esa manera y me parece francamente incongruente el argumento para sostener que tendría que haber, en rigor, un esquema de comprobación en los términos que se está planteando como dijo alguno de mis colegas, por la vía de los recibos y de otras cuestiones. Es un contrato de prestación de un servicio, consistente en la dispersión del dinero a través de esos monederos.

Esta nueva participación del consejero Marco Antonio Baños retornó el punto de la comprobación de gastos porque el PRI lo presentó como gasto ordinario. La reclasificación que realizó la Unidad de Fiscalización, dijo Baños, hizo imposible al PRI comprobar por medio de recibos. El consejero Baños no estuvo a favor de la consejera Marván y dio sus argumentos. Parece que Baños desvía la discusión hacia un punto de mediana trascendencia.

La consejera Marván Laborde respondió al consejero Baños Martínez lo siguiente: 
Con todo respeto, no veo la contradicción. A lo largo de todo el proceso se fue hablando con el partido político, se fue trabajando con él, de hecho fueron sumando una serie de pruebas, de alegatos, de discursos y no hay manera de ligar los contratos presentados con las tarjetas, por una sola razón: "Las tarjetas son innominadas". Es decir, para todo efecto práctico son efectivo.

Gracias al trabajo de la Unidad de Fiscalización y gracias al trabajo de colaboración con la Comisión Nacional Bancaria y de Valores, hemos sido conocedores hoy de dónde y cómo se dispuso de ese efectivo. Pero creo que no hay ninguna contradicción.

\section{La consejera Marván defendió su argumentos porque mencionó que el} trabajo de recopilar las pruebas con el PRI fue un proceso y no como dejó entrever el consejero Baños que no podían comprobar los recibos por una acción de la Unidad de Fiscalización. Marván rebatió de forma precisa los argumentos de Marco Antonio Baños.

\section{Después el turno le tocó al consejero Francisco Javier Guerrero}

\section{Aguirre, en su intervención mencionó lo siguiente:}

En ese sentido, la litis del asunto original era determinar el origen, el destino y la aplicación de los recursos, que a través de diversas tarjetas expedidas por Banco Monex fueron distribuidos por la otrora Coalición Compromiso por México, el Partido Revolucionario Institucional y el Partido Verde Ecologista de México.

Queda claro y aquí viene, quizá, la diferencia de fondo que tengo con mis colegas y amigos que he mencionado, que desde su punto de vista estos contratos no satisfacen el destino de los recursos, eso es lo que ellos han señalado. Hacen una serie de elucubraciones y de circunstancias que ellos ponen sobre la mesa estableciendo que eso sería suficiente para establecer una multa, como ya he referido, de 75 millones de pesos.

Evidentemente no comparto ese criterio por varias razones. La primera razón es que no encuentro precedentes en la historia de la fiscalización de México donde un asunto que no ha sido conocido de manera profunda por las partes involucradas simplemente se resuelva sobre la mesa con una propuesta que están haciendo. Como resulta con frecuencia, esa propuesta se obtiene, si mis cuentas no fallan ya van cuatro votos hasta el momento que he escuchado, si obtuvieran el quinto voto pues obviamente estarían en esa ruta; pero veo varias dificultades de carácter legal en torno a esta propuesta que ellos están haciendo.

Por supuesto el quid del asunto, y lo he comentado con mis colegas, es que ellos aprecian desde su óptica, muy respetable por cierto, que esta explicación de los contratos simplemente no es satisfactoria. Toda vez que ellos estiman que no es satisfactoria, inmediatamente proceden a proponer sobre la mesa esta multa de 75 millones de pesos. En todo caso, habría también que decir que en el caso de todas las demás coaliciones, una vez que esta reclasificación que ha hecho la Unidad de Fiscalización, que por cierto acompaño, el caso de lo que el Partido Revolucionario Institucional ha señalado en su argumentación, está establecido que desde su óptica, a pesar de no sentirse obligados, están poniendo sobre la mesa una explicación sobre el destino.

El quid de esta litis reside en establecer si este argumento es suficiente o no es suficiente. Creo que en todo caso, quiero conceder razón a los proponentes, habría que quizá llevar a cabo una investigación adicional, quizá incluso un procedimiento oficioso, en todo caso. Pero lo que sí me parece que en este momento, desde mi punto de vista, no acompañaré con mi voto esta propuesta, es que al ponerse sobre la mesa en este preciso momento podrían estarse violando algunas disposiciones de legítima defensa de la parte involucrada. 
La intervención del consejero Francisco Javier Guerrero mencionó que el punto central de la discusión es el origen, destino y aplicación de los recursos. Guerrero dijo que se precisaba una investigación más profunda del asunto. No era adecuado dar su voto al punto de que hubo rebase de topes de campañas. Además que se podrían violar, dijo Guerrero, disposiciones legales de defensa de la parte acusada.

Luego de la participación del consejero Francisco Javier Guerrero Aguirre, el representante del poder legislativo, el diputado Javier Corral cuestionó al consejero acerca del punto principal que trató la denuncia del caso Monex.

Pero le voy a dar lectura muy rápida a la página 95, el estudio de fondo de la Resolución: "Del análisis de los documentos y actuaciones que integran este expediente, así como lo vertido por los representantes de los partidos políticos que integraron la otrora Coalición Movimiento Progresista y el Partido Acción Nacional, a través de sus respectivos expedientes de queja, se desprende que el fondo del presente asunto consiste en determinar el origen, el destino y la aplicación de los recursos que a través de diversas tarjetas, expeditas por Banco Monex, S.A. Institución de Banca Múltiple, Monex Grupo Financiero (en adelante Banco Monex, S.A.), fueron distribuidas por la otrora Coalición Compromiso por México (...)".

¿Después de esta lectura, usted podría sostener que está fuera de la litis de la Resolución y de la discusión el destino de los recursos?

El consejero del poder legislativo, Javier Corral Jurado, hizo lectura del proyecto de resolución y puso énfasis que en el centro del asunto también estaba el destino de los recursos. La intervención de Javier Corral fue para presionar al consejero Guerrero acerca de si estaba de acuerdo en que el punto fundamental era el destino de los recursos.

El consejero Guerrero Aguirre respondió al diputado Corral que una revisión más profunda del caso sería más útil.

Tiene usted razón lo leí también en mi intervención, quizá no fui suficientemente claro, en la litis general del asunto sí está involucrado el asunto del destino. Quizá lo que estaría, en todo caso, sujeto a una interpretación, sería si la acreditación de estos contratos per sé serían suficientes para establecer este destino. 
El consejero Guerrero puso en claro que el eje de su argumento en su anterior participación versaba sobre la utilidad de establecer si los contratos eran comprobatorios del destino de los recursos.

Posteriormente, el representante del PRD ante el IFE, Camerino Eleazar Márquez Madrid, le cuestionó que no se apegó a la legalidad, a lo cual el consejero Guerrero mencionó que no existió una ilegalidad del PRI en cuanto al uso de los recursos. Luego tomó la palabra el representante del PRI ante el IFE, José Antonio Hernández Fraguas para decir que la actuación del PRI fue conforme a derecho y las pruebas presentadas confirman la legalidad. El representante del PRD, Camerino Eleazar Márquez Madrid cuestionó al representante del PRI en lo siguiente:

Desde luego también preguntarle qué nos puede decir respecto al flujo de los saldos de prepago por parte del Grupo Comercial Inizzio, S.A. de C.V. que sumaba un total de cargas de 46 millones 179 mil 09 pesos y que estamos hablando solamente del período del 18 de abril, al período del 24 de mayo. Estamos hablando del período de campañas, estamos hablando de montos de hasta 20 millones de pesos, como se pudo acreditar el día 22 de mayo; de montos de 8 millones de pesos el día 16 de mayo y así diferentes cifras.

El representante del PRD cuestionó las inconsistencias de cifras que presentó la empresa en distintos periodos y no concordaban con las que mencionaba el partido. La participación de Camerino fue útil debido a que mostró la fragilidad de los argumentos proporcionados por el PRI.

El representante del PRI, respondió que:

También como ha quedado claro, y ya lo dejé suficientemente establecido, mi partido político no celebró ningún contrato con ninguna otra empresa que no sea Alkino, por lo tanto, desconocemos cualquier situación que pudiera haberse desarrollado de carácter contractual, por supuesto, con las otras empresas mencionadas. Con esto espero, señor representante, dar respuesta a sus preguntas.

La respuesta del representante del PRI volvió a reiterar la inocencia del partido y que no sabía de algún otro contrato. 


\title{
Luego el representante del Poder Legislativo, Javier Corral Jurado, le preguntó al representante del PRI:
}

¿Cuál es el control que el Partido Revolucionario Institucional tuvo sobre el destino del dinero? Porque se ha afirmado que en realidad este dinero sólo fue orientado a 13 estados de la República, e incluso sólo en uno, entiendo que en el estado de Hidalgo, se ejerció el 26 por ciento de estos recursos. ¿Qué sucedió o qué pasó en las otras 19 entidades?, ¿Cuál es el control que el Partido Revolucionario Institucional tiene de esto?

Pero a 13 Estados fue ese dinero, ¿Qué pasó con los otros Estados del país?, ¿Cuál es el control que se tiene de ese dinero?

\author{
El consejero del Poder Legislativo, Javier Corral preguntó al \\ representante del PRI sobre el control que el partido tuvo de los \\ recursos de los que disponía. Su pregunta iba dirigida a un punto \\ esencial acerca del control que también debe tener el partido y no sólo
} la Unidad de Fiscalización.

\section{A lo que José Antonio Hernández Fraguas dijo:}

Mi partido político definió darle prioridad al cuidado y a la vigilancia del desarrollo del Proceso Electoral Federal en estas tres entidades, y por eso definió que los recursos que fueron destinados con el pago de estas tarjetas, con las tarjetas Monex, fuera aplicable solamente en estas tres entidades. Las razones son internas que los partidos políticos tienen para poder saber a dónde fortalecer su estructura electoral y a dónde fortalecer su capacidad de vigilancia de los procesos electorales.

\section{La respuesta del representante Fraguas fue evasiva a la pregunta hecha} por Javier Corral.

\section{Después, el representante del poder legislativo, Fernando Belaunzarán, continuó con los cuestionamientos al PRI.}

\footnotetext{
¿Por qué Alkino que no se dedica a las tarjetas prepagadas? Si el Partido Revolucionario Institucional quería tarjetas prepagadas, por qué no va a una institución que se dedique a hacer las tarjetas prepagadas, y va a una empresa que se dedica a otra cosa.

Segunda pregunta: ¿Si cuando fueron con Alkino, Alkino les dijo y les comentó que no tenía dinero para fondear esas tarjetas? O sea, no se dedica a las tarjetas. La pregunta es si ¿También ustedes estaban enterados de que Alkino no tenía recursos? Es decir, cuando uno busca una empresa, si dices: "Quiero 66 millones de tarjetas prepagadas". Uno tiene que preguntarse dos cosas: Que se dedique a eso, a hacerlas prepagadas, y dos, que tenga los recursos para hacerlo. ¿Por qué Alkino, si Alkino les comunicó que no tenía ese recurso y tenía que subcontratar?.
} 
La participación de Fernando Belaunzarán puso énfasis acerca de la incongruencia entre la empresa que prestó el servicio aunque no se dedica al rubro del financiamiento. El diputado Belaunzarán procuró indagar más allá del reporte de la Unidad de Fiscalización. Su intención era procurar la lógica del proceso de préstamos que presentó el PRI a la Unidad de Fiscalización.

José Antonio Hernández Fragua, representante del PRI, aseveró lo siguiente:

¿Por qué Alkino? En el objeto social de esta empresa aparece que se dedica a la fabricación de estas tarjetas y no podemos definir exactamente por qué no quedó claramente establecido que no tenía los recursos suficientes.

El representante del PRI se basó en el objeto social de la empresa para responder al diputado Fernando Belaunzarán y nuevamente no dio una respuesta clara a la pregunta. Luego hizo uso de la palabra el consejero del poder legislativo, Ricardo Astudillo Suárez para reafirmar las conclusiones dadas por la Unidad de Fiscalización.

\section{La representante del PVEM, Sara Castellanos Cortés dijo:}

La conclusión es tajante, no se recibieron aportaciones de personas morales, porque el dinero que se estaba manejando era de las prerrogativas del partido político y las empresas prestaron un servicio de distribución. Los datos desacreditan el dicho de los denunciantes, en el sentido de que diversas empresas hayan aportado recursos con la finalidad de pagar la emisión de tarjetas y la dispersión de recursos.

El Partido Revolucionario Institucional contrató un servicio de dispersión de recursos, adquiriendo tarjetas de prepago y cubriendo en su totalidad las obligaciones pactadas con la empresa referida. Todos los pagos fueron depósitos y transferencias que se efectuaron a través de operaciones dentro del propio sistema bancario.

La intervención de la representante del PVEM tuvo lugar en un momento en que se polemizaba entre los consejeros del poder legislativo y de los representantes del PRD contra el representante del PRI. Reiteró que los recursos eran del partido y que la empresa que contrataron sólo realizó la dispersión del dinero. Sara Castellanos procuró 
apoyar los argumentos presentados por el representante del PRI y así evitar que siguieran los continuos cuestionamientos.

El diputado Ricardo Mejía Berdejas realizó una crítica a la actuación de la Unidad de Fiscalización.

Seguidamente retomó la palabra el consejero Marco Antonio Baño Martínez para responder a las críticas hechas por el diputado Ricardo Mejía Berdejas. Donde mencionó que:

Pero voy a un punto fino aquí, y me voy a referir a la propuesta de los Consejeros Electorales Benito Nacif, Lorenzo Córdova, Alfredo Figueroa y María Marván, no puedo acompañar esa propuesta y no la puedo acompañar por una simple y sencilla razón, es una propuesta que suena, en términos estéticos, a una intención de fundar por fundar el procedimiento.

No hay un argumento de fondo y voy a decir por qué: Porque la Unidad de Fiscalización, cuando hizo la revisión de la información que proporcionó el Partido Revolucionario Institucional con relación a este tema, reclasificó el gasto, reclasificó la característica del gasto realizado a través del tema de Monex y dijo: "No se trata de gasto ordinario, sino de gasto de campaña". Pero eso proviene de una decisión de la autoridad. Luego, después decimos, para fundar, al menos en la perspectiva de mis colegas que lo han propuesto así, que no se comprobó el destino de esos recursos, no se puede comprobar de esa manera, porque la forma en que fue planteada la información proveniente del partido político había considerado esta parte, vamos a ver cómo los demás partidos políticos hicieron algo parecido, pero esta parte venía asignada a los gastos ordinarios.

Un acto de autoridad ha generado una reclasificación de ese gasto y correctamente se está sumando a los topes de gastos de campaña. Quererlo fundar de esa manera, y lo digo con todas sus letras, sería violatoria de garantías. Aquí se estaría vulnerando el tema de las garantías procesales para que se pueda hacer la comprobación correspondiente.

Por eso no puedo acompañar, bajo ninguna consideración, la propuesta que mis colegas están formulando con relación a este tema. Ni siquiera ha habido una reflexión respecto a simple y llanamente que no hay un planteamiento de parte del partido político involucrado, compruebe fehacientemente el destino de estos recursos; tampoco ha habido sobre la mesa, de parte de mis cuatro colegas, supongo que ellos ahondarán en su propuesta en la segunda intervención, pero no hay argumentos para sustentar la propuesta en el sentido de que debería ser fundado por no haberse aclarado correctamente el destino. La verdad es que lo demás es discurso.

\section{El argumento que presentó el consejero Marco Antonio Baños fue que} la reclasificación de los recursos estaba violando las garantías del PRI. También mencionó que el PRI no pudo comprobar el destino de los recursos. Estaba en contra de que se declarase fundado el procedimiento porque ni siquiera estaba fundamentado el destino de los recursos.

\section{El Consejero del poder legislativo, Fernando Belaunzarán Méndez le} pidió su opinión al consejero Baños de lo siguiente: 
El argumento básico para determinar que los gastos de la estructura electoral son de gasto ordinario, es que se realizan posteriormente a que concluye la campaña electoral, que es dos días antes del proceso. Entonces se les paga. Nada más le quiero preguntar al Consejero Electoral Marco Antonio Baños si cree que eso tiene lógica, en el caso del Partido Revolucionario Institucional, cuando los pagos se dieron desde el mes de abril, con gran anticipación al día de la Jornada Electoral, cuando está establecido que cobró 18 mil 700 pesos más o menos un representante general, si cree que eso es lógico por un día de trabajo, el día que se da, dos días después de concluida la campaña.

Si eso es creíble, 18 mil 700 pesos más o menos, que el testimonio es que cobraron los representantes generales por un día de trabajo. El Reglamento de Fiscalización sólo habla de créditos con la Banca Comercial y pone requisitos estrictos y requisitos para informar, etcétera y prohíbe con la Banca de Desarrollo. El Reglamento de Fiscalización es más bien restrictivo, en la lógica de fiscalización, los sistemas son restrictivos, no es permisivo. ¿En qué se basa para decir que el Reglamento permite créditos con empresas mercantiles, si no están establecidos en el Código Electoral y sólo habla de Banca Comercial?.

El diputado Fernando Belaunzarán lanzó una pregunta al consejero Marco Antonio Baños sobre su comentario acerca de qué elementos mencionaba el Código Electoral para que el consejero Baños dijera que se podían establecer contratos con empresas mercantiles. Marco Antonio Baños en esta sesión se prestó para dialogar y diferir con las posturas de los representantes de los partidos y los consejeros del Poder Legislativo. Aunque sus argumentos tuvieron la intención de aportar elementos jurídicos en la discusión.

\section{El consejero Marco Antonio Baños argumentó lo siguiente:}

Ya el tema fundamental ahí fue la temporalidad en la que se suscribieron los contratos dentro del período de campaña. Toda esa parte fue lo que la Unidad de Fiscalización ha tomado como base para reclasificar el gasto. Con eso no tengo diferencia, así que no veo la razón, honestamente, de la pregunta ni del diferendo.

La otra parte, no está prohibido, dígame usted dónde está prohibido. La ley y el Reglamento no dicen: "Debe", dice: "Podrán". Es potestativo también. La única prohibición expresa es la que tiene que ver para la suscripción de esos contratos con la Banca de Desarrollo. El Reglamento lo que hace, ciertamente, es poner criterios y elementos que deben actualizarse cuando se hagan ese tipo de contrataciones con la Banca.

Marco Antonio Baños mencionó en su participación coincidía con el diputado Fernando Belaunzarán en el rubro de la temporalidad de los contratos. Mientras que su alegato sobre la interpretación de la norma difiere. El artículo 123 del Reglamento de Fiscalización del IFE (Los partidos políticos no podrán solicitar créditos provenientes de la banca de 
desarrollo para el financiamiento de sus actividades) y el artículo 77 del COFIPE (No podrán realizar aportaciones o donativos a los partidos políticos ni a los aspirantes, precandidatos o candidatos a cargos de elección popular, en dinero o en especie, por sí o por interpósita persona y bajo ninguna circunstancia: ambos mencionan lo mismo sobre: g) Las empresas mexicanas de carácter mercantil) ambos artículos no mencionan acerca del financiamiento de una empresa mercantil sólo dice el artículo 77 del COFIEPE que no puede realizar aportaciones. En ese espacio que no estaba contemplado por la ley (que una empresa mercantil hiciera un financiamiento) fue por donde el PRI ocupó para realizar su maniobra.

El representante del PRD ante el IFE, Camerino Eleazar aportó lo siguiente al debate:

En ningún apartado del Código Electoral se establece que está permitido solicitar un crédito a una sociedad mercantil. Está permitido contratar servicios y las cuentas por cobrar se pagan. Eso es diferente a ir a contratar un financiamiento de dudosa procedencia, de cuantías que no es sostenible objetiva y racionalmente que esas empresas sean solventes.

Por eso incurrimos en una actitud probablemente de encubrimiento y eso genera una consecuencia de absoluta inequidad e ilegalidad. Creo que estamos ante un hecho verdaderamente trascendente. Por eso me parece que sí deberíamos declarar fundada esta Resolución, toda vez que también la cantidad de facturas Monex que tenemos y que incorporamos al expediente y que no se atienden, estamos nosotros estableciendo que para la empresa Inizzio S.A. de C.V. hay más de 20 facturas que debe establecerse de dónde surge este dinero.

El punto aportado por el representante del PRD, es esencial debido a que marcó el punto nodal del caso Monex. La ley prohíbe préstamos con una entidad mercantil. El PRI contrató a Atama. Ésta por su parte fue con otras empresas a conseguir el financiamiento. No solamente prestó un servicio sino también una subvención.

El consejero Marco Antonio Baños le pidió al representante del PRD ante ese órgano que respondiera la siguiente pregunta:

Pero él lo equipara a la contratación de un financiamiento. ¿Bajo qué argumento puede sostener técnica, jurídica, contablemente, como válido eso? . 


\section{La contestación del Camerino Eleazar fue:}

Pero, quiero referirme a la página 197, en el último párrafo hace referencia justamente a un servicio financiero. No fueron a prestar un servicio para arreglar los teléfonos del Partido Revolucionario Institucional, fueron a dar unas tarjetas, que luego fueron a utilizar en Zara y en otras empresas mercantiles porque por cierto, tienen esos detalles.

La respuesta dada por el representante del PRD fue contundente. El reporte brindado por la Unidad de Fiscalización donde remitió a un documento entregado por el PRI, menciona que fue un servicio financiero, es decir, un financiamiento.

\section{El consejero representante del poder legislativo, Javier Corral Jurado} tomó la palabra y dijo:

Es claro que se contrató, además del servicio de dispersión del dinero, un financiamiento, toda vez que nunca antes fue alimentada la cuenta. Pero quiero ir al fondo de la cuestión. Quiero ir y no calificar, con buena o mala voluntad, a quienes insisten en fincar en un contrato la justificación del destino de los recursos, que me parece que éste es el tema medular. Por supuesto que no se prohíbe ni está restringido, salvo en un caso en la ley el poder contratar con empresas mercantiles servicios los partidos políticos.

Que el partido político puede contratar directamente. Claro que sí, ¿Y por qué triangularon? Esta es la pregunta fundamental, ¿Y por qué se trianguló? Incluso con empresas con múltiples deficiencias no solamente económicas, sino de objeto social y de socios e incluso de omisiones fiscales en sus declaraciones estratégicamente ausentes, una de ellas en el mes de julio y la otra sin Ejercicio Fiscal en el año 2011.

Si podía contratar el Partido Revolucionario Institucional directamente, ¿Por qué se ha hecho toda esta, no triangulación sino piramidación? Si lo podían hacer directamente, porque es evidente que cuando estalló el escándalo tenían la alternativa o de reconocer aportaciones privadas, y eso obviamente violenta el límite de ingresos permitidos por la legislación en materia de financiamiento privado y se tuvo que reconocer, como aquí lo hemos escuchado que era financiamiento público.

No me pueden decir ahora que el contrato garantiza el destino de los recursos cuando el mismo Coordinador de la campaña había negado que los usaran. Los contratos hay que ubicarlos en el texto, en el contexto para eliminar el pretexto.

El consejero del Poder Legislativo, Javier Corral, tocó un elemento esencial en la discusión, no era necesario, desde su perspectiva, realizar un proceso tan complejo cuando el PRI pudo ir directamente a banca Monex y pedir el servicio de dispersión. Además mencionó que los priístas estaban en una disyuntiva cuando se dio a conocer el asunto, o 


\title{
reconocer que eran aportaciones privadas o hacer por una serie de maniobras jurídicas que eran recursos del mismo partido. Este es el tema político que en el Consejo General del IFE nunca se habló sino que solamente se basaron en aspectos jurídicos.
}

\author{
Posteriormente, tomó la palabra la consejera María Macarita Elizondo
}

Gasperín.

En el Proyecto de Resolución, se sostiene que los pagos realizados por las diversas empresas, de estos grupos, a la cuenta del Grupo Comercial Inizzio en Banco Monex fueron producto de distintas relaciones contractuales entre sociedades legalmente constituidas.

Resulta insostenible, a mi juicio, por ejemplo, un razonamiento, en el sentido de que está prohibido a los partidos políticos, aspirantes, precandidatos, candidatos, aceptar aportaciones o donaciones en efectivo o en especie de iglesias o agrupaciones religiosas, pero sí pueden recibir préstamos o créditos de ellos. Tampoco sería admisible señalar que un partido político está impedido para recibir una aportación en especie de un partido político extranjero, pero sí préstamos de dinero o créditos de dichas organizaciones.

Ambas cuestiones llevan al absurdo y son un sustento que no puede tener base. Por lo tanto, motiva mi reflexión. Consecuentemente, considero que la prohibición que establecen los sujetos impedidos para realizar aportaciones o donativos de los partidos políticos, aspirantes, precandidatos y candidatos, configura un mandato general que precisa los tipos de financiamiento prohibidos expresamente por la ley.

Ahora bien, se sostiene en el Proyecto de Resolución que la contratación de un servicio para el diseño de una estrategia que permitió al partido político presunto infractor dispersar recursos durante la campaña, como lícitos, en mi concepto existen normas que se omitieron examinar en cuanto a su dimensión y alcance, y que una diversa interpretación de éstas podría conducir a considerar la utilización de instrumento que impide y obstaculiza el debido ejercicio de una facultad fiscalizadora de este Instituto Federal Electoral.

Tal como se razona en el Proyecto de Resolución, la contratación de un servicio para el diseño de una estrategia de dispersión de recursos, entraña en sí mismo un contrato de mutuo con interés; esto es, un préstamo o un crédito a favor del partido político presunto infractor, que le permitió dispersar recursos durante la campaña presidencial.

Hay mucho a mi juicio a establecer como fundamentación y motivación de este expediente y debe llevarse una interpretación armónica y funcional de los artículos 41, Base II de la Constitución Política; 77, párrafos 2 y 3, inciso g) del Código Federal de Instituciones y Procedimientos Electorales, así como los artículos 52 y 53, del propio Reglamento de Fiscalización. Con claridad, la posibilidad de que los partidos políticos contraten créditos pero única y exclusivamente con instituciones financieras, lo que deberá efectuar de manera directa, a mi juicio debe ser así y no a través de intermediarios. De esta manera no es factible que a través de un intermediario o varios se pueda allegar de recursos provenientes de eso, por lo cual me separo por otras razones de lo argumentado por mis propios colegas y me esperaré a la segunda intervención, a que precisen, en su caso, la individualización de la sanción.

La consejera María Macarita Elizondo hizo ver la paradoja que existe en la ley cuando prohíbe que está proscrito que personas ajenas de los partidos e instituciones proporcionen donaciones o recursos en efectivo pero no diga nada sobre el financiamiento que podrían otorgar a los partidos políticos. En esta reflexión, se deduce el problema de la 
normatividad en materia electoral en casos como los de Monex, los partidos procuran encontrar sitios donde no haya declaración explícita de la ley para utilizarlos a su favor en alguna acción ilegal.

\title{
Luego de la intervención de la consejera María Macarita Elizondo, el consejero Alfredo Figueroa Fernández hizo una nueva consideración.
}

Porque lo que aquí estamos discutiendo es si existe o no existen elementos que permitan a la autoridad electoral establecer con toda claridad si se comprobó o no se comprobó el destino de esos recursos en un conjunto de elementos que están presentes. Se ha hablado por cierto de reclasificación.

\begin{abstract}
No, nadie está reclasificando un gasto. Lo que ha ocurrido es que un partido político dice que ese gasto estaba orientado a lo ordinario y en la investigación de un procedimiento sancionador de carácter fiscal, de fiscalización, lo que se ha acreditado es que ese dicho no puede sostenerse por un conjunto de razones, entre las que está cómo el dinero fue ejercido en cada uno de esos momentos y si se acompaña la idea de que esos recursos fueron ejercidos durante el período de campaña, debe acompañarse la idea de que esos contratos con las personas a las que se les estaba prestando un determinado servicio, esas personas no tienen que ver con los recursos que aquí se establecen y por lo tanto, en la consistencia de la argumentación de la propia Unidad de Fiscalización en términos de la clasificación del gasto, está en cuestión frente al Consejo General, cuando este lo que hace es analizar los méritos de los elementos que tenemos sobre la mesa.
\end{abstract}

Este es el fondo de la discusión que hoy estamos manteniendo aquí junto con, desde luego, la preocupación de si una empresa mercantil puede financiar o no puede financiar, evidentemente merced a una interpretación que no puede ser sino armónica y sistemática, de lo que dice la Constitución Política, la ley y nuestro propio Reglamento, porque no hay expresamente una prohibición en la reglamentación de carácter electoral, pero desde luego sí una diferencia de interpretación. Este es el fondo de esta circunstancia y por lo tanto, no hay un deseo de establecer la fundamentación.

La segunda participación del consejero Alfredo Figueroa, volvió al punto que anteriormente se había hablado en las tres últimas participaciones. No existe una reglamentación acerca del financiamiento de una empresa mercantil y por tanto es cuestión de interpretación. También puso en la mesa el argumento de la Unidad de Fiscalización de que los recursos llegaron a los representantes generales y las tarjetas y por consiguiente no existe un contrato. El aspecto a destacar es que el consejero Figueroa retomó los datos de la Unidad de Fiscalización, elemento que en las últimas participaciones de los consejeros no se había utilizado, sino de manera indirecta. 


\section{El consejero Lorenzo Córdova Vianello, realizó su segunda intervención acerca del caso Monex y mencionó lo siguiente:}

Creo que los contratos, lo que prueban es la existencia de dos voluntades coincidentes, en prestar un servicio por un lado y, en remunerarlo por el otro. Pero, sigo insistiendo que sería mal mensaje hacia el futuro, si aceptáramos los contratos como mecanismos de comprobación de las erogaciones que realizan los partidos políticos.

Llama la atención no solamente que no todos los contratos estén respaldados por un recibo, sino que también como ocurre con el que tengo aquí en la mano, un contrato firmado el 13 de diciembre de 2011 tenga anexo un recibo fechado, un comprobante de que se recibió por parte de uno de los contratantes, el dinero, el 31 de marzo de 2012 cuando el primer fondeo del que da cuenta la investigación a las tarjetas Monex es del 2 de abril de 2012. Es decir, está fechado antes. Evidentemente no estoy poniendo en duda la legalidad de estos documentos, evidentemente esto respalda una erogación, un pago hecho por otra vía, en efectivo tal vez, no lo sé, pero no con los monederos Monex porque no es congruente con lo que la investigación nos revela.

En síntesis, creo que es necesario una comprobación adicional que respalde lo que dicen los contratos, y eso es lo que no tenemos.

El consejero Córdova dijo que las dos voluntades tanto del PRI y Alkino en obtener un préstamos y la empresa de darlo eran claros. Otro aspecto fue que se puso en evidencia la incompatibilidad e incongruencia de las pruebas presentadas por el PRI porque se dio un recibo antes de que se hiciera un pago. Además de que pidió a la Unidad que se hiciera otra pesquisa adicional.

\section{El consejero Benito Nacif Hernández participó por segunda vez y en} su intervención dijo lo siguiente:

Por esa razón, creo que parece ser una regla formal, tiene una enorme importancia para proteger la integridad del sistema de fiscalización, porque básicamente lo que hace el Partido Revolucionario Institucional es tratar de acreditar el destino de esos recursos con contratos que son documentales privadas, documentales privadas que no concuerdan con las documentales públicas que tenemos que, en este caso, son los informes que pasa la Comisión Nacional Bancaria y de Valores respecto al destino de esos recursos.

Son dos fuentes de información que se contradicen, que no se confirman unas a otras y que no hay una aclaración, el dinero va por un lado y los contratos por otro. Nunca hay un vínculo claro entre estos dos elementos y, me parece que, esa falta formal tiene una enorme repercusión, como la de origen que es no haber reportado lo que es claramente un préstamo, que es una obligación establecida en el Reglamento, el Reglamento dice: "Lo tienes que reportar cinco días hábiles después de haberlo firmado"; y si hay una reestructuración también tienes que reportarlo.

¿Por qué existe esa regla formal? Para que reconstruyas una historia si alguien presenta una denuncia y entonces trates de justificar algo que la regla te obliga a dar esa información a la Unidad de Fiscalización y tiene una enorme importancia porque precisamente esas reglas buscan evitar que se generen esquemas de financiamiento paralelo que si se denuncian no puedas reconstruir documentos para después sostener que ese financiamiento fue legítimo.

Creo que estamos ante la violación de estas reglas formales, que son de una enorme importancia para mantener la integridad del Sistema, y por eso es importante darle la gravedad que corresponde e imponer la sanción que corresponde en este caso. 
Benito Nacif habló sobre la contradicción que existía entre los informes que presentó el PRI y los reportes de la Comisión Bancaria y de Valores. Estos elementos que rescató, son trascendentes porque según el consejero Nacif ni los contratos comprobaron el destino de los recursos. Además tocó otro aspecto que no dijeron los otros consejeros, que la Unidad de Fiscalización cada vez que hace una investigación (en este caso una reclasificación), si encuentra alguna contradicción reporta al partido y este partido tiene la posibilidad de presentar los documentos de descargo.

\section{El representante del PAN ante el Consejo General del IFE, Rogelio} Carbajal Tejada, cuestionó al consejero Marco Antonio Baños.

Pregunta el Consejero Electoral Marco Antonio Baños que ¿Con base en qué se puede catalogar este contrato como un financiamiento? Pues con base en el objeto del contrato.

Con base en esto, se puede definir que esto es un financiamiento, no ir a comprar un folleto o pedir la impresión de un documento o montar un espectacular, que eso podría catalogarse como la prestación de un servicio. Me podrán decir, claro, prestar dinero también es un servicio. Sí, es prestar un servicio financiero, es un financiamiento. Vaya, para no ahondar en la discusión, voy a leer lo que contestó el Partido Revolucionario Institucional a la queja, foja 74 del Proyecto de Resolución. Dice, segundo párrafo de la foja 74: "En lo que se refiere al financiamiento recibido por el Partido Revolucionario Institucional de parte de Alkino, Servicios y Calidad, S.A. de C.V. por un monto de 66 millones 326 mil 300 pesos..." ". No sigo más la cita, es decir, el contrato lo dice, el partido político lo acepta, es un financiamiento.

Esta participación del representante del PAN, puso en evidencia que el mismo PRI aceptó en un documento que envió a la Unidad de Fiscalización que fue un financiamiento y no como lo argumentaban sus representantes ante el Consejo General que fue un contrato de un servicio. Fue contundente la participación del representante.

Después de que el representante del PAN, hizo uso de la palabra, el representante del poder legislativo, Fernando Belaunzarán Méndez.

Estamos ante un gasto de campaña ilegal a través de una cuenta ilegal, que se pretende ocultar con el contrato de un crédito ilegal, que se dio a conocer después de negarlo y una vez concluido el Proceso Electoral Federal. Hecho, este 
crédito ilegal, con una empresa mercantil no idónea para otorgarlo y sin solvencia, que a su vez contrata a otra empresa mercantil en la misma situación, la cual también contrata a otra empresa "ídem". Ante eso estamos.

Algo que es preocupante, no abran el expediente de los créditos con empresas mercantiles, en condiciones, por cierto, mucho más favorables que en la Banca Comercial, como es el caso que nos ocupa, solamente por salvar al príncipe.

Estamos ante un fraude a la ley que se quiere justificar con otro fraude a la ley y esto, me parece, no lo debiéramos aceptar, porque no tiene, insisto, la menor lógica que alguien vaya con una empresa sin recursos a pedirle un préstamo, simplemente para lavarse las manos y no saber cómo pasó.

\title{
Al terminar, la intervención de Fernando Belaunzarán, el consejero Alfredo Figueroa Fernández quiso saber la opinión del primero respecto al tema de la no fundamentación de recursos.
}

Mi convicción en torno al particular la expreso y quiero saber su opinión, es que desde luego en relación a la característica de declarar fundado la no comprobación de recursos, ese monto no puede incorporarse por una razón: porque está comprobado que se pagó para esos intereses.

Es decir, no incorporarlos en la sanción por no comprobación de destino, está comprobado el destino, pero sí incorporarlos como el costo de gasto de campaña que representó un proceso de financiamiento en esa dirección. Por su opinión en relación al particular y su respuesta, Muchas gracias.

\section{A lo que el representante del poder legislativo respondió:}

Ahora, el Partido Revolucionario Institucional paga, pero lo cierto es que quien fondea la cuenta de Inizzio, que es la que va a los bolsillos de los representantes generales, son empresas mercantiles y eso viola claramente el Código Electoral, pero lo paga el Partido Revolucionario Institucional como diciendo, sí lo pusieron ellos o quien sea, me lavo las manos, pero al pagar me libro de toda responsabilidad.

Todos sabemos, si nos hacemos esta pregunta en privado y en conciencia, todos tendríamos la misma respuesta si decimos: ¿si no hubiera estallado el escándalo el Partido Revolucionario Institucional hubiera reportado de esa cuenta que está a nombre de Inizzio y hubiera pagado el dinero? Creo que todos nos contestamos lo mismo, en privado, en conciencia. Pero el caso es que lo pagó, porque después de estallado el escándalo y después de negarlo, no, Me parece que la falta no se borra simplemente porque uno paga, sobre todo cuando fue "atrapado en la movida".

\section{La respuesta presentada por el consejero del Poder Legislativo,} Fernando Belaunzarán, presentó su hipótesis acerca de los sucedido, que el PRI una vez descubierto en el asunto de las tarjetas Monex, pagó y de esa manera arregló la situación. El diputado hizo uso de su capacidad deducción para poner en forma más clara las amarras del suceso.

\author{
Luego tomó la palabra, Ricardo Mejía Berdejas, también representante \\ del poder legislativo.
}


el Partido Revolucionario Institucional fue pillado, fue sorprendido con toda esta madeja que se fue deshilvanando a partir de los operadores del estado de Guanajuato y todo lo que fue surgiendo.

Tan fue pillado que en un primer momento y de bote pronto Luis Videgaray lo niega, lo niega el vocero y luego ya, ante la evidencia de los hechos y para tratar de hacer un conteo de daños, sale a la palestra el hoy Procurador General de la República, Jesús Murillo Karam. Pero, evidentemente había una intención de evadir, de engañar, de ocultar una operación de financiamiento ilícito que estaba haciendo el Partido Revolucionario Institucional y aquí creo que está cuadrado que tiene que haber evidentemente una sanción.

Primero, porque si hubo el financiamiento, que es evidente que fue un préstamo y aquí coincido con el representante del Partido Acción Nacional, que aunque diga arrendamiento, "si tiene cola de pato, camina como pato y grazna como pato, es pato".

Entonces esto fue un préstamo, es evidente y fue un préstamo no reportado al Instituto Federal Electoral y ya ese solo hecho ameritaría una sanción. Por otro lado, está el tema del destino del gasto y por otro lado, está también la violación al principio de equidad.

\section{El representante del PRI ante el Consejo General del IFE, José}

\section{Antonio Hernández Fraguas respondió lo siguiente:}

Nosotros seguimos insistiendo en que este es un gasto ordinario y no gasto de campaña, toda vez que, si se estaba pagando a una estructura electoral y la estructura electoral actúa principalmente el día de la jornada, en el día de la jornada ya no hay posibilidades de hacer proselitismo, porque si alguno de los representantes lo hiciera, incurriría incluso en un delito electoral y podría hasta anularse la votación de la casilla, si es que se estuviera promoviendo el voto en ese momento.

Nosotros sí hemos considerado desde las primeras diligencias practicadas en el expediente, así como en la contestación al emplazamiento, alegatos y vista del asunto, que en los gastos realizados por el Partido Revolucionario Institucional y pagados en carácter de honorarios asimilados a salarios, aparte de nuestra estructura electoral, son de carácter ordinario y no de campaña. Sin embargo, en la secuela del procedimiento, atendiendo a los requerimientos de la autoridad fiscalizadora, entregamos la comprobación de la totalidad de lo erogado por el mencionado concepto, mismo que fue escrupulosamente revisado por la Unidad de Fiscalización.

Si este Consejo General determina hoy que los gastos referidos son de campaña, la Unidad de Fiscalización, que ya tiene la comprobación, tendrá que computarlos en ese rubro. Pero insisto, es hasta el día de hoy en que esta autoridad está determinando que son gastos de campaña. El artículo 346 del Reglamento de Fiscalización, establece: "Si durante la revisión de los informes, la Unidad de Fiscalización advierte la existencia de errores u omisiones técnicas, lo notificará al partido político, Coalición, Agrupación Política, Organización de Observadores u Organización de Ciudadanos que hubiere incurrido en ellos, según sea el caso, para que en un plazo de 10 días, contados a partir de dicha notificación presenten la documentación solicitada, así como las aclaraciones o rectificaciones que estimen pertinentes".

En este caso la Unidad de Fiscalización, pese a contar con toda la información contable del caso Monex, nunca notificó a mi partido político que omitió dicha comprobación de gastos en su campaña. Ahora, sin el cumplimiento de ese requisito, se pretende establecer una sanción violando el principio de legalidad y debido proceso.

\section{El representante del PRI presentó ante los participante del Consejo} General el argumento que sí se reasignó por parte del Consejo General y no se le avisó al partido con anterioridad, según se señala en la ley, por eso fue una violación a la norma. El razonamiento del representante del PRI, es erróneo debido a que el Consejo General no posee 
atribuciones para reasignar los gastos que presentó el PRI. Además la Unidad de Fiscalización tiene autonomía de gestión por lo que el Consejo General no puede recomendarle como realizar sus labores. Este argumento de José Antonio Hernández no poseyó la claridad y consistencia necesaria.

El consejero Marco Antonio Baños, posteriormente presentó otros argumentos.

Porque si es, desde mi punto de vista, válido la suscripción de los contratos mutuo con empresas. Por una razón sencilla. Primero, porque no está prohibido. En segundo lugar, porque el objeto de esos contratos no es una aportación, no consiste en un financiamiento como se ha querido decir en esta mesa, no se trata de una aportación a favor de un partido político ni de un donativo, sino de una cantidad que, en su caso, regresaría a la propia empresa.

Puede ser un préstamo, pero se trata de un recurso que no está siendo donado al partido político, que no está sirviendo para un financiamiento bajo la modalidad que se ha querido decir aquí. Creo que en esa parte no hay vuelta de hoja. Toda esa argumentación que se expresó respecto a que sólo se puede con instituciones bancarias, desde mi punto de vista, no se sostiene; y no se sostiene porque ya ha habido interpretaciones en otro sentido que han validado este criterio.

Ahora, desde mi punto de vista sigo considerando que es inadecuado el hecho de aprobar esta propuesta formulada por mis colegas, en el sentido de que esto se debe de declarar fundado. Claro que está fundado, está fundado para efectos de los topes de gastos de campaña, sería absolutamente incorrecto decir que la queja no se está declarando fundada, se está declarando infundada para efectos específicos de las aportaciones ilegales de empresas mercantiles, que ese era uno de los motivos de la Litis.

El consejero Baños retomó su razonamiento sobre los contratos que tienen validez del contrato entre PRI y Alkino. Además mencionó que ya se había dado (no deja en claro en qué lugar, si en el Consejo General del IFE o en otro lugar) interpretaciones que validaban el financiamiento con otras empresas que no sean bancarias.

\section{El representante del poder legislativo, Fernando Belaunzarán, cuestionó al consejero Marco Antonio Baños.}

Primero, usted menciona que si es préstamo no es financiamiento, pero la verdad es que los préstamos también sirven para financiar. Si uno compra un carro y pide un crédito bancario, ese préstamo te sirve para financiar, y así se dice. Si pedimos préstamos el país los hace para financiar distintas obras.

Me parece que, simplemente hacerle la aclaración de que las aportaciones pueden servir para financiar, pero también los préstamos. En este caso sirvió para financiar actividades de un partido político, este préstamo. 
Quiero ver si estaría de acuerdo con esa interpretación. Segundo, el Partido Revolucionario Institucional acaba de pagar, apenas la semana pasada, el último pago a Alkino, pero pagó de acuerdo a lo que terminaba en el mes de noviembre, entonces pasó el mes de diciembre, y dos meses más, esos dos meses más no le pagó los intereses que merecía.

Si no le cobra estos intereses, porque se tardó estos dos meses más, lo consideraría una aportación de una entidad mercantil, puesto que en los términos del contrato no se cumplieron en el sentido de que es una especie de días de gracia, en los cuales no pagó el partido político y no pagó la diferencia en intereses que estaban pactados.

\title{
El consejero Marco Antonio Baños tomó la palabra para responder al diputado Fernando Belaunzarán.
}

No hay contratación de un financiamiento, es lo que usted quiere que le diga, no opino eso, creo en otra cosa diferente, mi interpretación es distinta. Lo que ocurrió fue simplemente que se cubren los esquemas de implementación del servicio de la dispersión del dinero contratado. Ese es el punto.

Ahora, que los intereses deben tener algún tratamiento, quizá sí, no me parece que sea una aportación, me parece que son parte de los gastos, no me parece que deba ir, por cierto, a los gastos de campaña, porque la parte de lo principal, que es el dinero dispersado, que son los 66 millones de pesos, 50 millones y medio a las federales y 16 millones a las locales es la parte de lo principal, lo otro es, desde mi punto de vista accesorio, y eso tendría que ser informado y sumado al partido político en un esquema diferente, quizá los gastos ordinarios.

\section{El consejero Baños no respondió al cuestionamiento hecho por}

\section{Fernando Belaunzarán acerca del financiamiento y repitió que fue un servicio que prestó la empresa al PRI.}

\author{
Por tercer ocasión el consejero Alfredo Figueroa Fernández hizo uso \\ de la palabra y en su intervención dijo:
}

También es indispensable, en mi opinión, se ordene a la Unidad de Fiscalización, primero, declarar fundado el procedimiento administrativo como una propuesta concreta, en un Resolutivo adicional, el procedimiento sancionador incoado contra el Partido Revolucionario Institucional, con fundamento en el artículo 342, párrafo 1, inciso 1), del Código Federal de Instituciones y Procedimientos Electorales por incumplir las reglas establecidas para la comprobación del destino de los recursos de los partidos políticos.

Es mi opinión que debe establecerse la vista correspondiente para el Informe de Gastos de Campaña, es decir, para que se cuantifique en el Informe de Gastos de Campaña, además de la parte proporcional erogada, con motivo del contrato en relación a los intereses. Ambos elementos estarán presentes en esa vista. Adicionalmente, creo que debe señalarse en otro procedimiento, en su momento, la vista a la propia Unidad de Fiscalización sobre esta argumentación.

Estamos hoy analizando el origen y destino de los recursos de los partidos políticos. Eso es lo que está juzgando esta autoridad y clasificando, poniendo, ahora sí en claro, en qué se gastó este recurso. 
El consejero Figueroa dio un adelanto de su voto al declarar fundado el procedimiento en contra del PRI. Además propuso que la Unidad de Fiscalización realizara otra vista el rubro de gastos de campaña.

\title{
El consejero Lorenzo Córdova Vianello, realizó una observación acerca
}

\author{
del decurso de la discusión.
}

Solamente pido la palabra para dos puntos adicionales a la reflexión. El primero tiene que ver con este argumento que se ponía sobre la mesa, a propósito de la reclasificación y el estado de indefensión, se decía, en que se dejaría al partido político. El argumento aquí me parece que abriría la puerta, de darlo por bueno, a un problema no menor. Es cierto que esta autoridad electoral está proponiendo, está determinando que el monto de los 50 y tantos millones involucrado se compute como gasto de campaña y no como gasto ordinario, como lo pretendía originalmente el partido político denunciado, como lo ha sostenido sobre la mesa.

Porque si diéramos por bueno el tema de que la reclasificación, como se le ha llamado, del tipo de gasto supone o implica un estado de indefensión para el partido político, lo que estaríamos abriendo es la posibilidad que cuando llegara el Informe de Gastos Ordinarios, el Informe Anual, el partido político nos diría, con toda razón: "Oigan, no compruebo esto porque esto no es un gasto ordinario, tú mismo me dijiste que era un gasto de campaña".

\author{
En esta intervención del consejero Córdova retomó el elemento de la \\ indefensión que había expuesto el representante del PRI. Este \\ razonamiento que dio Córdova no es adecuado porque la instancia que \\ hizo esta reclasificación fue la Unidad de Fiscalización. Los atributos \\ que posee la Unidad le permiten reclasificar los gastos y pedir constancia \\ de los mismos a los partidos. No es propiedad del Consejo General la \\ reclasificación.
}

\section{El representante del PRD, Camerino Eleazar Márquez dijo lo siguiente:}

Solamente para establecer que de llegar a considerarse fundado, se dé vista a las autoridades correspondientes, fundamentalmente a la Fiscalía Especializada para la Atención de Delitos Electorales, a la Secretaría de Hacienda y Crédito Público y también a la Comisión Especial que se creó en la Cámara de Diputados.

Desde luego, me parece que es fundamental que se inicie un procedimiento oficioso para que se siga investigando sobre los otros contratos de otras empresas, porque el monto nosotros seguimos considerando que es una cantidad superior a los 75 millones de pesos, toda vez que hubo un pago permanente de 4 mil pesos del 15 de mayo al 30 de junio, a miles de ciudadanos que estuvieron en la operación y en la promoción del voto territorial a favor del Partido Revolucionario Institucional y de su candidato. 
El representante del PRD retomó el argumento acerca de dar vista a las autoridades gubernamentales más especializadas para conocer por medio de otras instituciones una visión ampliada del caso. Además de que instó a que se realizara otra investigación. Esta participación de Camerino pidió nuevamente otras pesquisas porque percibió que había inconsistencias en la investigación de la Unidad de Fiscalización.

\title{
El representante del PAN ante el Consejo General del IFE, Rogelio
} Carbajal Tejada, posteriormente dijo:

\begin{abstract}
Sostengo que este financiamiento en su origen es ilegal y lo sostengo por una sencilla razón, porque los ingresos no entraron jamás a una cuenta del Partido Revolucionario Institucional, como lo dice el Reglamento de Fiscalización. Evidentemente el destino de un financiamiento ilegal también lo es y por eso no está comprobado.
\end{abstract}

voy a empezar por la no información, por la violación al artículo 326 del Reglamento de Fiscalización, que obliga a todos los partidos políticos a informar cinco días después de la contratación de cualquier préstamo, crédito, financiamiento, como quieran llamarle, al Instituto Federal Electoral, cosa que no sucedió. ¿Por qué no sucedió?

Porque evidentemente el origen no es un financiamiento de una empresa mercantil. Por eso no sucedió ese Informe y por eso seguimos a la fecha esperando esa información de parte del Partido Revolucionario Institucional. A partir de ahí, evidentemente no hay un ingreso a sus cuentas y a partir de ahí, no hay un egreso de los monederos de sus cuentas y por lo tanto no hay facturas a nombre del Partido Revolucionario Institucional. Nadie haciendo esto en su sano juicio va a ir a pedir en la disposición de ese dinero una factura a nombre del Partido Revolucionario Institucional para comprobar el gasto, pues evidentemente que no lo va a hacer y no lo va a hacer porque el financiamiento es ilegal, porque el origen es ilegal.

Rogelio Carbajal Tejada mencionó en su intervención que fue un financiamiento ilegal porque no ingresó el dinero en la cuenta del PRI. Volvió al punto de que el financiamiento fue de una empresa mercantil. La participación del representante del PAN continuó con sus argumentos.

\section{El consejero del poder legislativo, Fernando Belaunzarán propuso} nuevos argumentos.

Lo racional es hacer lo sencillo y lo legal, eso es lo razonable. Lo que aquí nos están tratando de convencer es que lo razonable o esto fue hacer lo complicado y lo ilegal. Si a cualquier persona o entidad o institución le preguntas ¿Quieres conseguir unas tarjetas de pre pago? ¿Cómo le haces?

El camino más sencillo es ir a un banco, ir a una empresa que tenga recurso, etcétera, que se dedique a eso. El Partido Revolucionario Institucional hizo lo contrario, en "su verdad", pero además lo hizo violando la ley y los que conocemos 
eso, sabemos que el Partido Revolucionario Institucional, es conocedor de la legislación electoral y no iba a cometer estos gazapos tan fuertes a la legislación, a menos de que fuera una situación desesperada y aquí lo que estaban era buscando su coartada.

¿Por qué digo lavado de dinero? Porque eran recursos ilegales los que estaban en esa cuenta de Inizzio, Monex y que estaban fondeando a esas estructuras del Partido Revolucionario Institucional. Si ese es dinero ilegal y luego el Partido Revolucionario Institucional simplemente lo paga con el financiamiento público, eso se llama lavado de dinero con recursos públicos, hacer del dinero ilegal, dinero legal. De ese tamaño es la decisión; y lo peor de todo es que se justifique, con una historieta que no puede convencer a nadie, con dos dedos de frente.

\section{El diputado Fernando Belaunzarán fue más allá de sus argumentos} anteriores y dijo que presuntamente el dinero ilegal que recibió el PRI y que el partido lo pagó con recursos públicos, era lavado de dinero. Belaunzarán dio argumentos poco claros.

\section{El otro consejero del poder legislativo, Ricardo Mejía Berdejas sintetizó sus puntos de vista con respecto al caso Monex.}

Únicamente para concretizar, nosotros plantearíamos en base al artículo 326 del Reglamento de Fiscalización que, partiendo del supuesto que hubo un financiamiento, un crédito, un préstamo de Alkino al Partido Revolucionario Institucional y que no fue reportado conforme a la legislación, ahí hay ya una infracción. Eso sería el primer punto.

Lo otro, coincidimos, no queda claro el origen de los recursos y nos parece que se construye toda esta versión, para justificar un financiamiento ilegal, una triangulación que se hizo a través de varias empresas, que fueron empresas fachada. Lo otro que coincidimos con los Consejeros Electorales es el destino del gasto. Por todas estas razones, creemos que es procedente que este Consejo General tome a bien determinar una sanción, tomando en cuenta la reincidencia.

\section{El consejero del Poder Legislativo Berdejas apoyó que sí existió un financiamiento y que no era claro el origen de los recursos.}

\section{En su última intervención de la sesión del 23 de enero de 2013, el representante del PRI ante el IFE, José Antonio Hernández Fraguas mencionó.}

Por supuesto para insistir en el tema y comentar en función de lo que adujo el Consejero Electoral Lorenzo Córdova, de que había duda, cuando menos en la revisión de las pruebas que nosotros adjuntamos, simplemente decir que hay un principio que establece que habiendo duda, se absuelve, no se condena.

Que se revisara esto y simplemente que se tome en cuenta por supuesto lo establecido en el artículo 346 del Reglamento de Fiscalización en donde, si no se cumpliera nosotros creemos que no se está respetando nuestro derecho de audiencia y que, en todo caso, la sanción no sería aplicada legalmente. 
Cuando terminó el representante del PRI, el consejero presidente del IFE, Leonardo Valdés sometió a votación la resolución general del proyecto, fue aprobada por unanimidad. En el primer resolutivo, fue la aprobación del proyecto presentado por la Unidad de Fiscalización. En donde el voto fue unánime.

La votación en lo particular del segundo resolutivo con respecto a declarar infundado la ilegalidad del financiamiento de la campaña del PRI. El dictamen segundo fue aprobado por siete votos a favor y uno en contra. (A favor votaron Marco Antonio Baños Martínez, Lorenzo Córdova Vianello, Alfredo Figueroa Fernández, Francisco Javier Guerrero Aguirre, María Marván Laborde, Benito Nacif Hernández, Leonardo Valdés Zurita. En contra votó María Macaría Elizondo Gasperín. No estuvo en esta votación el consejero Sergio Ramírez García). Es interesante notar que este resolutivo fue aprobado por siete votos a favor $y$ uno en contra.

El tercer resolutivo versó acerca de dar vista a la Unidad de Fiscalización sobre la verificación de legalidad del contrato de AlkinoPRI. La votación fue un empate a cuatro votos por bando. (Los consejeros que estuvieron a favor fueron Lorenzo Córdova, Alfredo Figueroa, María Marván y Benito Nacif. Los consejeros que estuvieron en contra fueron Marco Antonio Baños Martínez, María Macaria Elizondo, Francisco Javier Guerrero). Por lo que el consejero presidente, Leonardo Valdés, pidió al consejero Sergio Ramírez que participara para desempatara la votación. El consejero Sergio García Ramírez fue hacía la posición de no apoyar la averiguación de legalidad. Es interesante que el 
consejero García Ramírez votó a favor y no respaldó al PRI que lo postuló para el cargo.

El siguiente resolutivo acerca de declarar infundada la ilegalidad del crédito. La propuesta tuvo cinco votos a favor y cuatro en contra. (Los que votaron a favor fueron Lorenzo Córdova Vianello, Alfredo Figueroa Fernández, Sergio García Ramírez, María Marván Laborde y Benito Nacif Hernández. Los que estuvieron en contra Marco Antonio Baños Martínez, María Macaria Elizondo Gasperín, Francisco Javier Guerrero Aguirre y Leonardo Valdés). Esta votación fue disputada

Posteriormente, se votó acerca del impacte y costos asociados al financiamiento. Fueron tres votos a favor y seis en contra. (Los consejeros que votaron a favor fueron Marco Antonio Baños Martínez, María Macarita Elizondo Gasperín, Sergio García Ramírez, Francisco Javier Guerrero Aguirre, Benito Nacif Hernández, Leonardo Valdés. Lo que votaron en contra Lorenzo Córdova Vianello, Alfredo Figueroa y María Marván Laborde). Después se votó sobre dar vista a la Unidad de Inteligencia Financiera. Se aprobó por unanimidad. Posteriormente, se votó acerca de dar vista a Comisión Nacional Bancaria y de Valores. También fue aprobada por unanimidad.

Luego se votó en dar vista a la FEPADE. El resultado de la votación, fue ocho votos a favor y uno en contra. (Los consejeros que votaron a favor fueron Marco Antonio Baños Martínez, Lorenazo Córdova Vianello, Alfredo Figueroa Fernández, Sergio García Ramírez, Francisco Javier Guerrero Aguirre, María Marván Laborde, Benito Nacif y Leonardo Valdés. La consejera María Marcarita Elizondo Gasperín votó en contra). 
También se votó por dar vista al SAT. El voto del Consejo General fue unánime.

\subsection{Conclusiones.}

En este capítulo se puede concluir que el principio de imparcialidad que es uno de los valores que debe rige la actuación institucional del IFE, es vulnerado en un primer momento por la forma de designación de los miembros del Consejo General del IFE que realizan los partidos políticos. Los últimos tres concursos para seleccionar a consejeros electorales del IFE, han estado marcados por la selección de consejeros afines a intereses de los partidos políticos. La discusión de los consejeros del Consejo General se llevó a cabo respetando sus fidelidades partidistas, mientras que en la votaciones se respetaron de forma parcial las lealtades partidistas como fue el caso del consejero Sergio García Ramírez en lo concerniente a revisar la legalidad del contrato PRI-Alkino.

En lo que respecta a las votaciones sobre cada resolución se pueden deducir aspectos interesantes de análisis. El primer resolutivo que versó acerca de declarar infundado el procedimiento. Es decir, no se comprobó que el PRI haya rebasado el tope de gastos de campaña. Este punto del dictamen del Consejo General fue muestra de la parcialidad con la que actuó el Consejo. Debido a que no se quiso hacer una pesquisa a fondo y sumar los recursos usados por el PRI en la campaña. 
Este primer resolutivo de declarar infundado el procedimiento, se debió complementar con el cuarto resolutivo que no agregó los intereses perdonados por Alkino al PRI como gastos de campaña para presentarse como un resolutivo. Además es menester mencionar que no se realizó el prorrateo (asignación puntual del gasto en campañas presidenciales, estatales, municipales de un partido) lo que demuestra una parcialidad al no investigar el gasto real del candidato Peña en su campaña. El Consejo General no profundizó en el asunto de rebase de topes de campaña del PRI en la elección de 2012.

El segundo resolutivo que trató sobre que fue infundado la ilegalidad del presunto financiamiento en la campaña presidencial de Peña Nieto. Este dictamen denota que el Consejo General actuó de forma parcial debido a que no quiso aplicar el principio de interpretación armónica y funcional. Cuando no existe un artículo en una ley que prohíba una acción, es preciso como lo argumentó la consejera Macarita Elizondo, que deba de existir una interpretación armónica y funcional con otras leyes (la Constitución Política) para no violar principio constitucional como la imparcialidad. La actuación de los consejeros electorales dejó que desear en este punto porque no desearon aplicar una técnica jurídica de interpretación armónica propia para el caso.

El tercer resolutivo que fue acerca de dar vista a la Unidad de Fiscalización para verificar la legalidad del contrato Alkino-PRI. Este dictamen demostró que cinco de los nueve consejeros electorales, no estaban conformes con la investigación hecha por la Unidad de Fiscalización. Este resolutivo demuestra que el procedimiento técnico realizado por la Unidad de Fiscalización contiene graves omisiones 
respecto a la validez de contratos. El elemento básico de una fiscalización para la Unidad de Fiscalización es el contrato, resulta desconcertante que la Unidad no haya verificado la legalidad del mismo antes de empezar el procedimiento.

El cuarto resolutivo que trató sobre rechazar otro resolutivo para incluir los intereses y comisiones como gastos de campaña. Este dictamen mostró que el Consejo General actuó de forma parcial debido a que fue demostrado por los representantes del PRD y PAN que no se habían cobrado los intereses por el retraso en el pago de parte del PRI. Cuando la empresa no cobró los intereses se podría deducir que fue una aportación al partido. Seis de los consejeros electorales no pretendieron adentrarse en este aspecto. Prefirieron no investigar este asunto.

Los resolutivos quinto, sexto y séptimo fueron sobre dar vista a la Unidad de Inteligencia Financiera, SAT, a la Comisión Bancaria y de Valores y a la FEPADE. Estos dictámenes del Consejo General del IFE mostraron que no existía una completa confianza en la investigación hecha por la Unidad de Fiscalización. A pesar de que la Unidad de Fiscalización ya había trabajado conjuntamente con otras instancias gubernamentales, algunos consejeros electorales no quedaron satisfechos por la premura de la pesquisa. Este elemento dejó entrever que los consejeros electorales prefirieron discutir el caso sin que la Unidad profundizara suficientemente en la investigación incurriendo en una posible parcialidad al no conocer todos los datos del caso y aun así votar los resolutivos. 
El aspecto que destacó por su ausencia en los resolutivos quinto, sexto y séptimo fue que otras instancias gubernamentales como Condusef no fueron tomados en cuenta para complementar un panorama amplio.

Otro elemento clave para verificar si el principio de imparcialidad se llevó a cabo fue la argumentación de los consejeros ciudadanos. La participación de los consejeros versó sobre un esquema de argumentos establecido que si bien fueron útiles $\mathrm{y}$ esclarecedores, no fueron en la mayoría de los casos más allá de los argumentos jurídicos. Por el contrario, los representantes de los partidos políticos opositores y los consejeros del Poder Legislativo, transitaron por los elementos jurídicos así como por consideraciones de orden político y lógico.

Es decir, pusieron argumentos que enriquecieron la discusión. El principio de imparcialidad no se cumplió en las votaciones ni en el trabajo institucional que fue insuficiente de parte de la Unidad de Fiscalización y del propio Consejo General debido a que no indagó profundamente el caso y aun así se decidió realizar las votaciones en esa sesión del Consejo General. Además que la ley no definía que hacer en el caso de financiamiento de una empresa mercantil.

Para cerrar este apartado, es menester responder a la pregunta que se planteó en la introducción de este capítulo. La cuestión era la siguiente:¿el consejo general del IFE vulneró el principio imparcial en la resolución del caso Monex? La contestación de la violación del principio de imparcialidad es notoria en la resolución que realizó el Consejo General del IFE porque se dejaron muestras patentes porque no se investigó a fondo el asunto, además de que se pasaron por alto 
elementos que comprobaban la culpabilidad del PRI en ese y otros delitos y que los consejeros electorales no quisieron profundizar.

Ante tal panorama, es preciso también investigar si el principio de legalidad se vulneró. El capítulo cuarto indaga este aspecto. 


\section{Capítulo 4. El principio de legalidad en las elecciones presidenciales de 2012.}

\subsection{Introducción.}

El capítulo cuarto que se presenta a continuación es el último de la tesis. En este capítulo se realiza una revisión del principio de legalidad en el caso electoral mexicano. El primer apartado hace una breve exploración de dos sucesos trascendentes para el ámbito de la fiscalización electoral en México como fueron "Amigos de Fox" y "Pemex". Estos dos acontecimientos dejaron cuenta del papel que jugó el IFE ante la violación fragrante de la ley de fiscalización de los partidos políticos. Además de que sentaron un precedente del rol que posee el IFE y su rol en la vigilancia de los recursos electorales y el impedimento de sujetos ajenos al sistema electoral pudieran actuar para obtener algún beneficio ilegal.

Posteriormente, dentro del apartado del análisis de los argumentos presentados por los consejeros electorales del IFE, en conjunto con los representantes de los partidos políticos y los consejeros del poder legislativo, se hará un recuento de sus razonamientos acerca del caso Monex. A la par se realizará un análisis de sus argumentos.

La pregunta que guiará este cuarto capítulo será: ¿el consejo general del IFE vulneró el principio de legalidad en la resolución del caso Monex?. 


\subsection{Legalidad en el contexto electoral mexicano.}

Para comenzar este apartado es preciso hacer un breve recuento de los elementos que conforman la legalidad y posteriormente se hará un recorrido de algunas decisiones legales que ha tomado el Consejo General del IFE.

El principio de legalidad posee algunas características que son menester tener en cuenta. Cuando se habla de legalidad se refiere a que cada decisión que se tome en el ámbito de la aplicación de las leyes debe de estar basada en la ley y no de manera tornadiza. La ley forma parte de un sistema jurídico en un sistema político. Toda institución que pertenezca al Estado mexicano es preciso que se apegue a las reglamentaciones que estén en vigencia en el momento. Las características que es menester que tenga la legalidad es que sea pronta y obligatoria.

La legalidad conlleva otra característica que es la concordancia de todas las leyes con una ley fundamental que rige un Estado. "El principio de legalidad alude a la conformidad o regularidad entre toda norma o acto inferior con respecto a la norma superior que le sirve de fundamento de validez, por lo que opera en todos los niveles o grados de la estructura jerárquica del orden jurídico". ${ }^{151}$

Un aspecto que es importante destacar es que la legalidad está ligada al ámbito de las atribuciones que tiene cada poder político en la

\footnotetext{
${ }^{151}$ Pérez Portilla, Karla. Principio de igualdad: alcances y perspectivas. UNAM-Consejo Nacional para Prevenir la Discriminación. México. 2005. Pág. 55.
} 
democracia. Es decir, que los poderes públicos deben de actuar en su espacio de acción. Por tanto "la ley rige el acontecimiento, el acontecimiento se sujeta a la ley". ${ }^{152}$ Cualquier hecho que se realice en política está dentro del ámbito de la normatividad jurídica. Es preciso que esté controlado por reglas. El rubro de fiscalización electoral no es la excepción. Las instituciones electorales son las encargadas de llevar a cabo la aplicación de la norma.

Otro elemento que conlleva el principio de la legalidad es la competencia para la aplicación de la ley. Las organizaciones electorales, como el IFE, posee atributos legales establecidos por la Constitución Política y otras normatividades que generan que sus cualidades institucionales se alineen a lo establecido por las leyes. Los procedimientos con que actúa una institución electoral son una parte importante de su funcionamiento. Estos procesos que realiza una organización electoral lleva a que pueda cumplir la normatividad de forma puntual.

Los tres principios que subyacen en la legalidad "es inválido todo acto de los poderes públicos que esté en contraste con la ley, es inválido todo acto de los poderes públicos que no esté expresamente autorizado por la ley y es inválida [...] toda ley que confiere un poder sin regularlo completamente." 153 Es decir, la legalidad posee un aspecto dinámico y otro estático. La característica dinámica en la legalidad es la conformidad de la actuación de una institución con las normas

\footnotetext{
${ }^{152}$ Islas Montes, Roberto. "Sobre el principio de legalidad". En Anuario de derecho constitucional latinoamericano. Fundación Konrad Adenauer-UNAM. Uruguay. 2009. Pág. 101.

${ }^{153}$ Citado en Islas Montes, Roberto. "Sobre el principio de legalidad". En Anuario de derecho constitucional latinoamericano. Fundación Konrad Adenauer-UNAM. Uruguay. 2009. Pág. 101.
} 
establecidas, mientras que la parte estática se refiere a quién debe hacer un acto y el cómo realizarlo. ${ }^{154}$

El núcleo del asunto de la legalidad es que una norma puede estar hecha de tal manera que esté apegada a la ley y sin embargo ser injusta. El derecho y la legalidad "garantiza [n] un mínimo de justicia en el sentido de que, cualesquiera que sean sus valores últimos en los que repose, el hecho mismo de existir proporciona algo tan elemental como el orden, la seguridad, la certeza y la previsibilidad de las acciones". ${ }^{155}$

Es preciso mencionar que la legalidad está ligada a la interpretación que hagan los impartidores de justicia de la ley. El juez es un elemento importante cuando se aplica la norma. En otras palabras, "el Juez [es] protagonista de la decisión". ${ }^{156} \mathrm{El}$ juez interpreta una serie de hechos y saca una conclusión. Posteriormente aplica la ley condenando o absolviendo al acusado.

Dentro de las actuales tendencias del derecho, los jueces son vistos como creadores del derecho. No sólo como aplicadores sino también como creadores del derecho. ${ }^{157}$ Esto es, difieren del tipo de juez como sujeto al texto y de la visión del juez como personaje sujeto a reglas rígidas y restrictivas en su interpretación. Cuando un juez toma una

\footnotetext{
${ }^{154}$ Islas Montes, Roberto. Ibíd.Pág 102.

${ }^{155}$ Prieto Sanchís, Luis. Apuntes de teoría del derecho. $2^{\circ}$ Edición. Editorial Trotta. España. 2007. Pág. 102.

${ }^{156}$ Valldecabres Ortiz, María Isabel. Imparcialidad del Juez y medios de comunicación. Universitat de Valencia y Tirant lo Blanch. Valencia. 2004. Pág. 98.

${ }^{157}$ Véase. Cuellar Vázquez, Angélica. "Estado del arte de la sociología jurídica en América Latina". En de la Garza Toledo, Enrique (Coord.). Tratado latinoamericano de sociología. $1^{\circ}$ Edición.Anthropos Editorial-UAM-I. España. 2006. Pág. 268.
} 
decisión, "los jueces involucran preferencias ideológicas, valores y hasta cálculo político". ${ }^{158}$

Un caso dentro de contexto mexicano que tuvo un enorme impacto dentro de la fiscalización electoral, fue el de "Amigos de Fox" y la desviación de recursos de PEMEX hacia la campaña presidencial de Francisco Labastida ex candidato priísta a la presidencia de la república en el año 2000. La queja que presentó el PRD contra el PRI, por el posible desvío de recursos de Pemex vía el Sindicato de Trabajadores Petroleros de la República Mexicana (STPRM) al PRI ante el IFE, fue el desencadenante que permitió que se comenzara la pesquisa. La Comisión Fiscalizadora de los Recursos de los Partidos y Agrupaciones Políticas empezó su trabajo con las averiguaciones previas que había realizado la PGR. Después que llevó a cabo su labor, la Comisión de Fiscalización expuso sus datos. La acreditación de que Pemex había otorgado un préstamo al STPRM, se había depositado en un banco y que los miembros de la Dirección de Finanzas del PRI habían cobrado el dinero fue comprobado.

El día que se realizó la votación del Consejo General, se definió el asunto en una apretada decisión. Fueron cuatro votos para confirmar la multa y tres en contra. Por tanto, el Consejo General decidió multar al PRI por una cantidad de mil millones de pesos porque no reportó a la institución la suma de quinientos millones de pesos recibidos por parte del sindicato de Pemex. A pesar de que esta acción que tomó el IFE y que quedó marcada en la historia de la democracia mexicana como un

\footnotetext{
${ }^{158}$ Cuéllar Vázquez, Angélica. Ibíd.Pág. 273.
} 
momento cumbre que ponía en evidencia la autonomía que había logrado el IFE, existieron una serie de sucesos que no fueron aclarados.

Algunos consejeros externaron su punto de vista en torno a la investigación hecha por la Comisión de Fiscalización al caso del financiamiento de PEMEX al PRI. Jaime Cárdenas, ex consejero electoral del IFE, mencionó que la rapidez con que se hizo la pesquisa dejó fuera un cúmulo de aspectos que no se investigaron. Entre ellos se hallan "la posible simulación en el llamado sorteo "Milenio Millonario" y el manejo financiero de las asociaciones Nuevo Impulso e Impulso Democrático, que aparentemente apoyaron la candidatura de Francisco Labastida [...], ni se determinaron las posibles violaciones a los topes de campaña". ${ }^{159}$ Estos elementos dejan entrever que los procesos de fiscalización electoral por la premura de tiempo pueden estar llenos de rezagos e inconsistencias legales y técnicas.

El caso de Pemex se cerró hasta el 26 de agosto de 2011, cuando se declaró prescrito el delito de peculado electoral del entonces dirigente del STPRM, Carlos Romero Deschamps. Algunos personajes del caso fueron arrestados como Melitón Cázares, Andrés Heredia y Alonso Beraza que pertenecieron a la Dirección de Finanzas del PRI. También la PRG libró órdenes de arresto a varios ex funcionarios de Pemex sin embargo no fueron detenidos porque el Sindicato probó que entregaron los recursos como parte de acuerdos contractuales entre ambas instituciones. ${ }^{160}$ Estos hechos que se hacen mención, dejan ver que hubo

\footnotetext{
${ }^{159}$ Cárdenas Gracia, Jaime. Lecciones de los asuntos PEMEX y Amigos de Fox. $1^{\circ}$ Reimpresión. IIJ. México.2004.Pág. 30. Disponible en formato http:http://biblio.juridicas.unam.mx/libros/3/1366/1.pdf)

${ }^{160}$ Hernández de Julián, Ana Leticia. "De los amigos de Fox al Pemexgate y Monex: Partidos e IFE hallan en las multas una forma cómoda de limpiarse". Sin embargo. Enero 25. 2013. En http://www.sinembargo.mx/25-01-2013/503340
} 
una serie de aciertos por parte de la autoridad electoral en el caso del "Pemexgate" pero también un cúmulo de graves omisiones en el asunto.

El caso de Amigos de Fox también fue un hecho trascendente. La Coalición Alianza por México y posteriormente el PRI presentaron una queja ante el IFE en contra del PAN por presuntas irregularidades en el financiamiento de dicho partido. La investigación del IFE rondó sobre las empresas de Lino Korrodi que también era responsable de las finanzas del PAN. También la participación de empresas extranjeras en el financiamiento de la candidatura de Vicente Fox fue la tónica del asunto.

En esta ocasión, el IFE se encontró con retrasos y obstáculos por parte de algunas dependencias de gobierno que se negaban a brindar la información requerida por la Comisión Fiscalizadora. Es interesante notar que el ex consejero Jaime Cárdenas Gracia menciona en su libro que "las restricciones a la información y la amenaza de denuncia fueron los mecanismos habituales de presión". ${ }^{161}$ La resolución del consejo general del IFE en el caso de "Amigos de Fox" multó al PAN con 360 millones 971 mil 39 pesos y al PVEM con 184 millones 198 mil 610 pesos.

Jaime Cárdenas sacó una serie conclusiones respecto a estos dos casos mencionados del proceso de fiscalización electoral. Es menester retomarlas debido a que siguen existiendo similitudes del caso Monex con respecto al de "Amigos de Fox" y el "Pemexgate". Cárdenas dice que los informes de campaña y los anuales son insuficientes para llevar

\footnotetext{
${ }^{161}$ Cárdenas Gracia, Jaime. Ibíd. Pág. 47.
} 
a cabo la fiscalización de los partidos políticos. Particularmente este punto siguió siendo relevante para el caso Monex debido a que existió una falla del PRI al presentar sus informes de gastos ordinarios y la Unidad de Fiscalización los reclasificó como gastos de campaña.

Es preciso que se den otras revisiones de parte de la autoridad como cuando se interpone una queja de un partido político, alguna denuncia de un particular o de alguna institución federal. Como se trató en el primer capítulo, se puede llegar a la conclusión de que se requiere de parte de la autoridad diversos mecanismos de vigilancia de los recursos de los partidos políticos. En el caso de los informes de campaña, la propuesta de ex consejero es que se analicen desde distintas perspectivas y no solamente se presenten los informes de campaña sin mayor análisis.

También concluye que la exhaustividad de las investigaciones es menester sea plena. Los argumentos que expresó Cárdenas en su libro, dejan ver que la Comisión Fiscalizadora del IFE no ahondó en otras posibles líneas de investigación como las que se presentaron en "Amigos de Fox" y "Pemexgate". Es preciso, arribar al fondo de la investigación y no sólo a la verdad procesal.

Otro elemento que rescató Jaime Cárdenas de los casos anteriormente mencionados es que el sistema jurídico mexicano explícitamente dice que solamente los partidos políticos y coaliciones deben recibir dinero público y privado. Cuando existe un caso en que en la norma jurídica no se tiene previsto qué hacer, debe prevalecer la práctica de los principios fundamentales de una democracia como lo son equidad, igualdad de 
oportunidades, rendición de cuentas sobre el origen de los recursos y destino de los recursos, transparencia y certeza.

Este aspecto es importante debido a que el mismo fenómeno se experimentó en Monex, no existía en la ley un artículo que prohibiera explícitamente que una empresa mercantil podría financiar a un partido político. La forma de poner fin a tales prácticas es realizar sanciones administrativas y fiscales a los operadores y receptores, además de la nulidad de la elección donde se presentó el caso o revocación de mandato.

Un elemento que es preciso tener en cuenta, menciona Cárdenas, es saber si una decisión jurídica es correcta. La primera es que debe de existir una elección adecuada de las normas y una interpretación aplicable al caso. La segunda es la comprobación fiable de los hechos. La confirmación de un hecho se da en grados de mayor o menor comprobación. Mientras que el tercer elemento es el procedimiento válido y justo. Esto es, que se realice el debido proceso.

También la propuesta del autor, es que existan sanciones políticas más severas para los infractores en materia de fiscalización electoral. Las multas económicas que se pueden imponer a un partido no logran disuadirlo de seguir violando la normatividad. Además que la sanción se paga con los recursos provenientes del presupuesto público, por tanto no afectan tanto a los partidos. Si existieran castigos severos políticamente, como anulación de la elección, revocación del cargo del candidato o suspensión temporal o definitiva del candidato, quizá habría más respeto a las leyes. 
La revisión de los anteriores puntos que expresó el ex consejero Jaime Cárdenas y que se escribieron en los párrafos anteriores, muestran cómo esos elementos aún faltan por llevarlos a la práctica institucional. A pesar de que ha pasado una década después de que se presentaron los casos de Amigos de Fox y el Pemexgate, continúan existiendo las inconsistencias organizacionales que vio Cárdenas en su tiempo como consejero del IFE.

El caso de Monex contó con una insuficiente revisión de los informes de campaña, también existió una premura de parte de la Unidad de Fiscalización de los Recursos de los Partidos Políticos por dar a conocer los informes de los partidos, además de que no se tenía previsto en la norma jurídica que hacer cuando una empresa mercantil extiende un préstamo financiero a un partido político. Mientras que la sanción que se aplicó al PRI por el caso Monex no fue severa para disuadirlo de no realizar tal acción.

El principio de legalidad con que se rige el IFE es menester revisarlo, por tanto es preciso revisar la actuación del consejo general del IFE en el caso Monex que se hará en el siguiente apartado.

\subsection{Evaluación del caso Monex por el Consejo General del IFE.}

Para iniciar el proceso de examinación del caso Monex por el Consejo General del IFE, es preciso tener en cuenta que el principio de legalidad que se está trabajando en este apartado posee varios aspectos. Uno de 
los elementos que lo conforman es el apego a los reglamentos institucionales además de la normatividad electoral y la constitucional. El otro punto es el alineamiento a los procedimientos de actuación de la institución. Con estas dos características se puede percibir si existió el principio de legalidad.

Otra acotación que es menester precisar es que el presente análisis se basará en el estudio de los argumentos brindados por los consejeros. ${ }^{162}$

Es preciso decir que los argumentos dados por los integrantes del Consejo General del IFE además de los representantes de los partidos políticos y los consejeros del poder legislativo fueron tomados del documento de la acta sesión del 23 de enero de 2013 del Consejo General del IFE. Los principales razones que proporcionaron los consejeros en el momento en que hicieron uso de la palabra son los que se transcriben en el texto. Después de escribir una parte de la argumentación se presentará la observación de la actuación del participante.

El consejero Alfredo Figueroa Fernández es el primero que tomó la palabra después de que se presentaron los informes realizados por la Unidad de Fiscalización.

¿Qué se pudo acreditar entonces en esta lógica y circunstancia? Primero, hay que cuestionarnos si el origen de estos recursos es legal o no lo es. En este sentido, el Proyecto de Resolución señala que el origen no es ilegal desde la perspectiva electoral y no lo es porque la cuenta con la que al final del día se sufraga cada uno de estos recursos, es una cuenta que corresponde al Partido Revolucionario Institucional, devengando cada uno de esos recursos a la empresa Alkino.

\footnotetext{
${ }^{162}$ Por argumento se entiende "un razonamiento que se emplea para probar o demostrar una proposición, o bien para convencer a otro de aquello que se afirma o se niega". Fernández Ruiz, Graciela. Argumentación y lenguaje jurídico. Aplicación al análisis de una sentencia de la Suprema Corte de Justicia de la Nación. $1^{\circ}$ Edición. IIJ-UNAM. México. 2011. Pág. 8. Disponible en formato: http://biblio.juridicas.unam.mx/libros/libro.htm?l=3016
} 
A partir de ese momento, en mi opinión, hay un desvanecimiento del empleo de esos recursos y de su destino, y el Partido Revolucionario Institucional no acredita, en todos los elementos que presentó a esta autoridad, el empleo de esas tarjetas Monex, con el propósito de erogar la estructura de representantes de casilla y representantes generales que nos habría anunciado. No lo acredita y tan no lo acredita que la propia ruta de los recursos empleados en esta dirección, muestra con toda precisión que no fue el gasto que se estableció en esas entidades y que de las indagatorias y muestras que hizo la propia autoridad, acreditó que no había representantes de casilla que hubieran recibido tarjetas, que no había representantes distritales que hubieran recibido tarjetas y, por lo tanto, no puede acreditarse que para ese objeto fueron precisadas.

Por lo tanto, en este sentido y circunstancia, estaré proponiendo a este Consejo General declarar fundado el procedimiento en contra del Partido Revolucionario Institucional, por no haber acreditado el destino de estos recursos, asociados a lo que nos señaló que los emplearía. Desde luego que se trata, por la temporalidad, por la geografía y por cómo se movió el dinero, de recursos que se asocian a la campaña electoral del Partido Revolucionario Institucional en términos generales. No hay como tal la comprobación que requiere un caso como este para poder señalar que, efectivamente cada una de esas 7 mil tarjetas estuvo asociado al pago de quien se nos señaló debía hacerse.

Esta primera participación del consejero Alfredo Figueroa hizo resaltar que el origen de los recursos es legal, de acuerdo a la investigación de la Unidad. Habría que decir que conforme avanzó la sesión se tuvo que admitir que era preciso dar nueva cuenta a otras instancias gubernamentales como SAT para poder confirmar o desmentir la legalidad en otras áreas como serían la fiscal, mercantil. Se puede decir que aunque existió legalidad del origen del recurso priísta en el ámbito electoral es preciso que otras entidades gubernamentales validen de forma rigurosa la legalidad del dinero. En el caso Monex se hizo sin embargo no se fue a fondo por parte de las otras instancias gubernamentales.

El primer aspecto de la Litis es confirmado por el consejero Figueroa sin embargo con respecto al destino de los recursos y su uso dejó en claro que la pesquisa realizada por la Unidad de Fiscalización desdijo los elementos presentados por el PRI en su reporte de uso de los recursos. El aspecto contradictorio que resaltó el consejero Figueroa fue que el PRI no presentó elementos jurídicos para la comprobación de su dicho de que las tarjetas fueron dadas a los integrantes priístas en la elección. 


\title{
La actuación del consejero Figueroa retomó elementos valiosos con
} respecto a la legalidad y trascendentes para el proceso de la sesión.

\author{
Posteriormente de la participación del consejero Alfredo Figueroa \\ Fernández, tomó la palabra el consejero presidente Leonardo Valdés para \\ agradecer y luego el representante del PAN ante el IFE cuestionó la \\ validez del reporte de la Unidad de Fiscalización.
}

La primera [pregunta] de ellas es si el origen de estos recursos es lícito o es ilícito. Mi respuesta, la argumentaré por qué, es que el origen es ilícito. La segunda pregunta que hay que formularse aquí, ya algo ha mencionado el Consejero Electoral Alfredo Figueroa, es si el destino de estos recursos fue comprobado o no fue comprobado. Mi respuesta y argumentaré por qué, es que no ha sido comprobado. La tercera pregunta es si este recurso es electoral o no es electoral.

Estamos ante un financiamiento paralelo del Partido Revolucionario Institucional. No puedo arribar a otra conclusión, primero, porque nadie va y pide un préstamos de 66.3 millones de pesos a una empresa mercantil que, según lo que pudimos indagar y del acceso que nos dieron al expediente limitado, pero algo nos dieron de acceso, de una empresa de carácter mercantil que en su declaración fiscal del año 2011, anual, se declaró en ceros.

. Y ¡oh! sorpresa, me dirán, bueno, claro, es que Atama fue y contrató o subcontrató a una supuesta filial que se llama Inizzio. Fíjense que Inizzio no presenta declaraciones fiscales, bueno, la Unidad de Fiscalización no las obtuvo, entre paréntesis, por eso cuestiono la exhaustividad de la investigación.

La siguiente pregunta respecto de la comprobación o no comprobación. El propio expediente habla, 191 es la cuartilla que tengo yo, que 44.6 millones de pesos fueron dispuestos en efectivo. Le quiero preguntar a las señoras y señores Consejeros Electorales, si el día demañana ustedes se encuentran que el tesorero del Partido Acción Nacional dispuso en efectivo de 44 millones de pesos del financiamiento del Partido Acción Nacional, como sea que lo haya obtenido, público o privado, les quiero preguntar si eso es lícito y no los comprueba.

Quiero subrayar la última parte del artículo 70 del Reglamento de Fiscalización, el titular de estas cuentas será, invariablemente, el partido político. El titular de la cuenta por la cual se dispersaron 66.3 millones de pesos a declaración de parte, es la empresa Inizzio, S.A. de C.V.

El representante del PAN pidió al Consejero presidente que el secretario del consejo que leyera los artículos 70, 72 y 76 del reglamento de fiscalización. Posteriormente se le solicitó al secretario del consejo que hiciera la lectura de las hojas 123 y 124 del proyecto de resolución. Posteriormente continuó Rogelio Carbajal en su argumentación.

Quiero subrayar la última parte del artículo 70 del Reglamento de Fiscalización, el titular de estas cuentas será, invariablemente, el partido político. El titular de la cuenta por la cual se dispersaron 66.3 millones de pesos a declaración de parte, es la empresa Inizzio, S.A. de C.V.

Por eso no se puede comprobar el destino, señoras y señores Consejeros Electorales, por eso hay una disposición de 44 millones de pesos en efectivo y eso está en el corazón de la fiscalización otra vez y por eso reitero lo que dije en mi intervención general, aquí está en juego si el Instituto Federal Electoral da pie a legalizar un financiamiento ilícito y no comprobado en su gasto o si sanciona al Partido Revolucionario Institucional por hacer aparentar, legalmente, estos actos cuando son a todas luces contrarios a la legislación electoral. 
En esta respuesta, el representante del PAN, continuó con su argumentación de su primera intervención para mostrar que existió una violación de la norma debido a que el PRI no tuvo una cuenta central (que es lo que marca la ley) y retomó de la ilegalidad del recurso. Además de que es preciso mencionarlo, el representante del PAN cuestionó la exhaustividad de la investigación realizada por la Unidad de Fiscalización.

En la intervención Rogelio Carbajal representante del PAN, dijo que el origen del dinero es ilícito. El argumento que presentó el representante del PAN aunque es valioso en términos lógicos. Con respecto a su argumentación con la no comprobación del destino de los recursos hizo una observación interesante en donde el dinero que dispuso el PRI fue en efectivo 44.6 millones de pesos y no en tarjetas. Este alegato es valioso porque reveló la paradoja en la documentación que manifestó el PRI ante el IFE, que usó dinero en efectivo mientras que ante la Unidad de Fiscalización presentó documentación donde acredita la supuesta dispersión del dinero por medio de tarjetas Monex. Otra posible violación que mencionó Carbajal es que el titular de la cuenta para uso electoral debió ser PRI y no Inizzio.

El consejero Marco Antonio Baños hizo uso de la palabra después de que acabó Rogelio Carbajal. El consejero Baños le preguntó al representante del PAN ante el IFE.

La primera es: Usted pidió la lectura del artículo 70 del Reglamento de Fiscalización, y ese artículo regula expresamente los ingresos en efectivo; eso no es igual a un servicio que tiene como propósito disposición de efectivo a través de los monederos, son cosas completamente diferentes. ¿Esas contrataciones se regulan por materia, por la Ley Electoral o por la Legislación Mercantil correspondiente? Ese es un punto que habría que dilucidar. ¿Cómo reporta el Partido Acción Nacional este tipo de cuestiones? Es nada más una pregunta para ir abonando en el debate y ver hasta dónde hay o no consistencia en los argumentos que va manejando la Unidad de Fiscalización. 
El consejero Baños le preguntó al representante del PAN sobre el artículo 70 del reglamento de fiscalización para cuestionar a Carbajal acerca de la reglamentación en efectivo que es preciso que sea el titular el partido mientras que la ley no menciona nada acerca de la prestación de un servicio de dispersión que pudiera ser una empresa.

En este punto es preciso mencionar que la interpretación que hicieron tanto el representante del PAN como el consejero Baños es divergente. Sin embargo el consejero Baños omitió la otra parte de la frase. Mientras que en la pregunta acerca de la regulación de los recursos si se hace en legislación electoral o mercantil, es una pregunta que intentó confundir porque se hace por los dos medios.

\section{El representante del PAN argumentó:}

La primera pregunta del Consejero Electoral Marco Antonio Baños no es clara, porque habría que leer completo el artículo 70. Dice: "Los ingresos provenientes de fuentes de financiamiento privado, así como de los recursos que provengan del financiamiento público”. Es decir, todo, no hay excepción.

En la investigación hay, dice Monex, en la investigación hay monederos a los que les fueron depositados 160 mil pesos, 200 mil, 240 mil, 47 mil 600, 50 mil, 32 mil 500, en fin, que superan evidentemente con mucho los 100 días de salario mínimo. ¿A qué voy con esto, Consejero Electoral Marco Antonio Baños? A que la labor de fiscalización seria sólo se puede hacer a través de la centralización de las cuentas y de que exista una póliza por un cheque emitido, y que esa póliza esté amparada también con una factura por la contratación de un servicio o por el pago de algún hecho.

Pero nos dice la investigación que Inizzio de fundió a través de una serie de empresas mercantiles y de personas físicas que le debían dinero. Pues si le debían dinero creo que debió de haber presentado declaraciones fiscales.

Por eso, evidentemente aquí no se puede fiscalizar; en primer lugar, porque el dinero no ingresó y no salió de las cuentas del Partido Revolucionario Instituto.

El representante del PAN, hizo énfasis en el artículo 70 que había que interpretarlo completo y no de forma parcial como lo hizo el consejero Baños. Posteriormente retomó su argumento sobre la centralización de la cuenta que es menester que tenga un partido político y de los debidos papeles que acrediten la acreditación de algún servicio, aspecto que el PRI no cumplió. Arribó a la conclusión que no era posible fiscalizar 
porque no había entrado o salido del PRI. Sus argumentos en cuanto a la ilegalidad del origen parecen contundentes y precisos.

\section{El consejero Marco Antonio Baños le hizo el pedido de que Rogelio} Carbajal respondiera las dos preguntas que le hizo.

Le rogaría que me contestara simplemente. Todavía no me contesta usted los temas de fondo, usted sigue haciendo una extrapolación, a mi modo de ver, de cosas que son distintas; el artículo 70 del Reglamento regula una cuestión muy específica y usted está todavía sobre una argumentación que no coincidimos.

Pero, me gustaría mucho escuchar sus argumentaciones, incluso sobre las otras dos preguntas que todavía no abordó.

\section{El consejero Marco Antonio Baños pidió a Rogelio Carbajal que contestara a las preguntas que le había formulado. La respuesta que dio el representante del PAN fue:}

Bueno, si no quiere entender mi respuesta ya ese problema no es mío, pero es evidente y es claro que un partido político, sólo puede gastar a partir de sus cuentas, no lo puede hacer a través de terceros y aprovecho para empezar a contestarle la segunda pregunta $u$ otra de las tres preguntas.

Es evidente que es gasto electoral, hay que leer el contrato que firman, supuestamente el $1^{\circ}$ de marzo. Asiste la Secretaria de Asuntos Electorales, firma el contrato la Secretaria de Asuntos Electorales y dice que va representando al partido político porque están buscando mecanismos aptos que respondan con velocidad, eficiencia y eficacia en la disponibilidad de recursos financieros para la estrategia electoral para el Proceso Electoral Federal 2011-2012. Eso dice la declaración 1.3 del contrato. Si eso no es gasto electoral, no sé qué es gasto electoral.

El mismo Proyecto de Resolución lo dice, señor Consejero Electoral, desvirtúa a través de una serie de encuestas y entrevistas el que ese dinero se haya destinado para esos efectos, de pagar representantes. Los mismos representantes niegan haber recibido monederos y haber recibido recursos a través de este mecanismo de financiamiento de prepago. En eso, el Proyecto de Resolución llega a esa conclusión, evidentemente es gasto electoral.

Al pedido de respuesta del consejero Baños, Rogelio Carbajal hizo más explícito su argumento sobre el gasto que puede hacer un partido político a través de sus cuentas y no por terceros. Retomó el argumento de que fue gasto electoral porque mencionó acerca del contrato que firmó el PRI con la empresa donde requirieron de sus servicios para la elección presidencial de 2012. Mientras que en el rubro del supuesto pago a los representantes, dijo que no existió evidencias de parte de la 
Unidad de Fiscalización de que las tarjetas hayan servido para realizar los pagos a los representantes priístas. Los alegatos realizados por el representantes del PAN mostraron que hubo una serie de inconsistencias y violaciones a la reglamentación en fiscalización.

El consejero Lorenzo Córdova Vianello hizo uso de la palabra.

Quiero articular mi intervención en tres rubros, tres rubros que coinciden en tres partes, tres partes que coinciden con la determinación de la propia litis y que sustentó el emplazamiento que se le hizo al partido político denunciado por parte de la Unidad de Fiscalización. Quiero hablar del origen, quiero hablar del destino y quiero hablar de la aplicación del gasto.

Por lo que hace al origen, efectivamente lo que se determina es un conjunto, no tanto de triangulaciones, sino si se me permite, de un sistema complejo de fondeo de las tarjetas que fueron utilizadas.

La investigación da cuenta, en la reconstrucción de esta trama, de eventuales vínculos jurídicos, comerciales o de otra naturaleza jurídica, entre estas empresas fondeadoras y la empresa subcontratada Atama. Pero, vale la pena señalar que la investigación de la Unidad de Fiscalización de los Recursos de los Partidos Políticos, no se limitó solamente a la reconstrucción de esta red de financiamiento y a la comprobación a través de acceso al Sistema Financiero Nacional de los montos precisos, las fechas exactas del fondeo de estas tarjetas, sino que también fue más allá.

Creo que vale la pena que eso se tenga, porque eso explica por qué no se continuaron las tramas de investigación, por qué se agotaron las líneas de investigación y permitiría ejemplificar por qué sí hubo un principio de exhaustividad en la determinación del origen de los recursos con los que se fondearon estas tarjetas.

De hecho, es precisamente esa investigación la que ha llevado a lo largo del proceso conducido por la Unidad de Fiscalización a comunicar presuntas irregularidades de tipo hacendario, de tipo financiero y eventualmente posibles irregularidades de tipo penal, derivadas de esa trama de financiamiento. Pero como se ha dicho en otras ocasiones en esta mesa, el Instituto Federal Electoral no es la Agencia Federal de Investigación (AFI) y el Instituto Federal Electoral no persigue ni lavado de dinero, ni persigue financiamiento del crimen organizado ni mucho menos.

El consejero Córdova Vianello en su participación contradice el dicho del representante del PAN, con respecto a la exhaustividad de la pesquisa hecha por la Unidad de Fiscalización. Con respecto a las facultades que posee la Unidad de Fiscalización para indagar este caso, el consejero Córdova dijo que hubo irregularidades hacendarias, financieras y penales. Sin embargo, la Unidad realizó todas las investigaciones correspondientes. Es contradictorio que se afirme por un lado la profundidad de la pesquisa hecha por la Unidad pero se pida que se dé nuevamente vista a las autoridades hacendarias hagan otra vez la investigación. Si no se posee con la suficiente certeza jurídica de 
una investigación que no incluye el ámbito de todas las facultades de fiscalización electoral del IFE, hubiera sido conveniente que la discusión en el consejo general del IFE se hubiera realizado cuando existiera la plena confianza en la pesquisa de varias instituciones gubernamentales que apoyen la investigación de la Unidad. Este hecho demuestra que hubo premura en el caso.

\section{A continuación siguió la intervención del consejero Benito Nacif}

\section{Hernández.}

En primer lugar, me parece que este Proyecto de Resolución informa sobre cómo se construyó la cadena de recursos y los rastrea hasta el Partido Revolucionario Institucional. Identifica los montos, los términos de los contratos y algo que es muy importante, cuál es el propósito con el cual ese dinero se ubicó en esta cuenta concentradora.

Desde esta cuenta concentradora también se dispersó hacia 7 mil 851 tarjetas. También eso está documentado. Se identifican aquellas tarjetas que no fueron fondeadas, pero que de alguna manera pudieron haber servido como un vehículo también para dispersar, pero queda acreditado que ahí no llegaron recursos. Asimismo, por el lado del destino, la Unidad de Fiscalización documenta lo que presenta el Partido Revolucionario Institucional respecto a cuál fue el destino de este dinero y el Partido Revolucionario Institucional nos dice que ese dinero sirvió para cumplir con obligaciones contraídas mediante la celebración de 7 mil 343 contratos de servicios personales, con enlaces territoriales, coordinadores territoriales, enlaces distritales y coordinadores distritales, obligaciones que ascendían a aproximadamente 50 millones de pesos.

El Proyecto de Resolución que nos presenta la Unidad de Fiscalización propone declarar infundados los dos agravios planteados por el quejoso. Uno, relacionado con el rebase de tope de gastos de campaña y nos dice: "Alkino monto involucrado no rebasa el límite de gastos de campaña". Asimismo el segundo agravio, que es el de un financiamiento ilegal, la Unidad de Fiscalización nos dice las obligaciones o los recursos pueden rastrearse, las cuentas del Partido Revolucionario Institucional con las cuales fueron fondeadas. Finalmente nos propone clasificar por la temporalidad en la que se ejerció el gasto, este gasto como gasto de campaña.

Me parece que todos los elementos que plantea la Unidad de Fiscalización, ciertamente no hay manera de imputar un rebase de tope de gastos, tampoco me parece un financiamiento ilegal; sin embargo, hay algunos aspectos del Proyecto de Resolución que me parece deben ser revisados, porque esos 50 millones de pesos que se destinaron para cumplir con las obligaciones, el Partido Revolucionario Institucional no aporta pruebas para relacionar las obligaciones de los contratos con las tarjetas y el dinero.

Por esa razón, propongo que declaremos fundado este Proyecto de Resolución, por la falta de no aclarar y precisar acreditando fehacientemente o con el estándar de pruebas que se requiere regularmente el destino de los recursos y que se sancione esa falta de acuerdo con los precedentes con los que contamos, que es el 150 por ciento del monto involucrado.

El consejero Benito Nacif mencionó que la pesquisa hecha por la Unidad de Fiscalización mostró que los delitos presentados por el PAN y PRD con respecto al financiamiento ilegal y el rebase de topes de campaña no tenían sustento. Sin embargo el destino de los recursos no fueron probados porque no existió la documentación que los avaló. El 
consejero Nacif dijo que estaba fundado el procedimiento en contra del PRI por la comprobación del destino de los recursos. La participación del consejero Benito Nacif estuvo apegada a la investigación hecha por la Unidad de Fiscalización y por esa razón propuso multar al PRI por no probar el destino de sus recursos.

\section{Luego continuó el consejero del poder legislativo Fernando Belauzarán.}

Veamos qué es lo que pasa. Lo que tenemos es un financiamiento paralelo que esperaba ser clandestino para hacer gastos durante la campaña del Partido Revolucionario Institucional. El escándalo estalla, lo niega el Partido Revolucionario Institucional, lo niega explícitamente el Partido Revolucionario Institucional en varias ocasiones y después de transcurrida la elección lo acepta.

Pero si el Partido Revolucionario Institucional necesitaba un crédito y necesitaba 66 millones de pesos, díganme por qué va con una empresa que efectivamente no se dedica a los créditos, tiene una razón social totalmente distinta, hace gestoría y además no tiene los recursos suficientes, es como si uno quiere pedir un sushi en una pizzería, no tiene ninguna lógica. ¿Y qué hace Alkino? Que no tiene los recursos, en esta invención que crearon para tapar lo del financiamiento paralelo.

¿Qué hace Alkino? Pues Alkino tampoco va a una institución crediticia, va con una empresa, incluso menos solvente que ella, porque además quien aparece como dueño de esa empresa, uno está muerto y otro es empleado de otra persona y no tiene esa capacidad financiera. Es más, no declara a la Secretaría de Hacienda y Crédito Público, no tiene trabajadores pero le piden 66 millones de pesos. La verdad es que no checa. El Partido Revolucionario Institucional acaba de pagar casi 6 millones de pesos en intereses, por 3 por ciento, cuando los intereses, si hubieran sido al 3 por ciento, hubiera sido el doble.

Es decir, esta empresa que no tenía ni siquiera para costear una nómina, ahora presta 66 millones de pesos y además a la baja de la banca comercial, es la usura a la inversa. No tiene lógica, pierdes más.

Es obvio que esto no se cumplió en el préstamo que pidió el Partido Revolucionario Institucional, pero también es obvio que está totalmente fuera del Reglamento pedir un préstamo o tener un préstamo con una Asociación Mercantil.

El Reglamento de Fiscalización es muy explícito con que los créditos se hacen con los Bancos y prohíbe la Banca de Desarrollo, pero sólo habla de la Banca Comercial para pedir créditos.

Posteriormente el diputado Fernando Belaunzarán pidió al secretario del consejo, Edmundo Jacobo que leyera el artículo 72 donde se habla acerca de las cuentas abiertas por un partido y el ingreso de fondos de acuerdo a lo establecido por el Código y Reglamento de fiscalización. Para luego continuar con su argumentación.

No hay manera de hacer gastos en campaña, dice, en campaña no hay manera de hacerlo fuera de una cuenta del partido político y tiene una lógica, las cuentas del partido político las puedes fiscalizar. Si no hubiera habido escándalo ni nos hubiéramos enterado que existía esa cuenta de una empresa llamada Inizzio con unas personas fantasmas, que tienen un domicilio fiscal en un consultorio dental. 
El consejero del poder legislativo, Fernando Belaunzarán hizo una revisión del proceso del caso. Cuestionó la lógica del asunto porque puso en evidencia que una empresa que no se dedica a prestamos los hizo y debido a que no tenía dinero pidió dinero a otra firma. Además que puso en evidencia que los accionistas y el domicilio fiscal de la empresa no existen. Es valioso la aportación que hizo Belaunzarán debido a que en la lógica jurídica debe hacer "la exigencia de rigor en el razonamiento jurídico 'efectivamente' garantiza la objetividad e imparcialidad del juicio". ${ }^{163}$ Es decir, verificar los argumentos y darle coherencia con los hechos acaecidos por darles validez. El diputado no se quedó solamente con los argumentos presentados por la Unidad de Fiscalización sino que intentó darles sentido.

\section{Posteriormente habló la consejera María Marván Laborde.}

Entender cuál es el origen del dinero, entender cuál es el destino del dinero y cuál es la aplicación del mismo, así como determinar si debe o no ser gastos de campaña. En el último punto no me detendré, creo que está claro, ahí acompaño el Proyecto de Resolución, no vería la manera de sostener que esto no es gasto de campaña. Respecto al origen del dinero se nos habla de la contratación de un servicio de carácter mercantil de dispersión de dinero. Creo que aquí está el primer eufemismo y el primer eufemismo es porque con este contrato en realidad se contratan dos cosas, se contrata un esquema de financiamiento, en tanto este no recibe de manera originaria el dinero del Partido Revolucionario Institucional, sino que alguien, alguna de estas empresas pone el dinero y además se dispersa el dinero.

El análisis del mapa del dinero, complejo por cierto, nos da cuenta de que el dinero, hasta donde llega nuestra investigación, estaba en el sistema financiero, que finalmente es lo que normalmente investiga la VIF (Value Investigación Forum), pero no nos dice en qué momento el Partido Revolucionario Institucional financia ese servicio de dispersión del dinero, eso sucede hasta que paga este crédito, este financiamiento, llamémosle como le queramos llamar.

Creo que la Unidad de Fiscalización hace una serie de diligencias en las que logra revelar el mapa diseñado del dinero. Lo menos que habría que decir es que hay una obra maestra de ingeniería financiera. El ingenio revelado en este mapa está claro, lo que logra además es no aclarar el destino del dinero. Acompaño a mis compañeros los Consejeros Electorales Lorenzo Córdova, Alfredo Figueroa y Benito Nacif en las vistas que se tienen que dar, la eficiencia o no de las mismas tampoco nos toca juzgarlo en esta mesa, acompaño a mis compañeros en que sea este declarado gasto de campaña y que deba declararse fundado en lo que hace a la aplicación del dinero.

Creo que el argumento del Consejero Electoral Lorenzo Córdova, respecto al contrato como prueba de la aplicación última del dinero, es pertinente, especialmente en este caso, que el contrato dispersa efectivo, para todo efecto práctico las tarjetas de débito son efectivo.

\footnotetext{
${ }^{163}$ Rosales Gramajo, Fernando Javier. Lógica jurídica. Instituto de Investigaciones Jurídicas. Universidad Rafael Landívar. Guatemala. 2010. Pág. 107. http://biblio3.url.edu.gt/Publi/Libros/Logica-Juridica/04.pdf
} 
La consejera María Marván mencionó que fue gasto de campaña lo que el PRI reportó a la Unidad de Fiscalización. La siguiente parte de la intervención de Marván trató sobre un punto clave que pudo afectar a la legalidad. La Unidad presentó el reporte donde habló de un término "contratación de un servicio de carácter mercantil de dispersión de dinero" que según la consejera hizo alusión a un financiamiento y la dispersión de dinero. Este hecho deja entrever que no existió claridad en los conceptos que presentó la Unidad de Fiscalización, se pudo prestar a confusión y distorsión del ámbito jurídico. Hubiera sido interesante que en la sesión del 23 de enero de 2013 el titular de la Unidad de Fiscalización, Alfredo Cristalinas Kaulitz hubiera asistido para despejar dudas y ayudar a la interpretación del documento que presentó la Unidad. Por último, hizo énfasis en clarificar si el contrato que mostró el PRI era prueba de la aplicación del dinero.

\section{El consejero Marco Antonio Baños Martínez dijo lo siguiente:}

\footnotetext{
El tema central es que cuando se ha informado sobre el tema de los recursos dispersados a través del tema Monex o del sistema contratado por vía de Monex, el Partido Revolucionario Institucional lo ha clasificado como gasto ordinario. Evidentemente ese argumento ha sido revisado, ha sido analizado en una perspectiva diferente por la Unidad de Fiscalización y en eso tenemos coincidencia con esa Unidad.
}

Hay argumentos para sostener que en vez de tratarse de recursos de gasto ordinario, deben ser considerados como de gastos de campaña y esa consistencia tendremos que verla con el resto de los informes que se presentarán respecto de los demás partidos políticos. Hasta ahí no tenemos ningún problema, pero ¿A dónde quiero llegar?

Que lo que ha ocurrido con la reclasificación del gasto es, en rigor, un acto de autoridad que ha reclasificado el gasto del Partido Revolucionario Institucional y lo ha sumado a gastos de campaña y no a gastos ordinarios. Entonces, ¿Cómo solicitar esa comprobación? En rigor la autoridad la que ha determinado que se gastó de esa manera y me parece francamente incongruente el argumento para sostener que tendría que haber, en rigor, un esquema de comprobación en los términos que se está planteando como dijo alguno de mis colegas, por la vía de los recibos y de otras cuestiones. Es un contrato de prestación de un servicio, consistente en la dispersión del dinero a través de esos monederos.

El consejero Marco Antonio Baños hizo énfasis en que si existió una reclasificación por parte de la Unidad de Fiscalización de los reportes que presentó el PRI como gasto ordinario, era poco factible que el PRI pudiera comprobar recibos que no tenía en el momento de presentar la 
declaración. El proceso de fiscalización que realiza la Unidad de Fiscalización está prescrito en su reglamentación.

El primer momento es la preparación y entrega de informes donde los partidos cuentan con sesenta días hábiles, el segundo momento es cuando se revisan los informes. Para informes de campaña, la Unidad cuenta con ciento veinte días hábiles para la revisión. El tercer paso es la retroalimentación con los partidos políticos y su derecho de audiencia donde pueden existir omisiones o errores que la Unidad manda al partido y el partido tiene diez días hábiles para responder. En el transcurso de los días hábiles de respuesta del partido, la Unidad de Fiscalización se reúne con el representante del partido ante el IFE y los responsables financieros para garantizarles su derecho de audiencia. Se repite este mismo proceso hasta que se hayan aclarado los puntos que no lo estaban. Por último, la Unidad realiza una revisión final y elabora un informe.

Por tanto, los argumentos presentados por el consejero Baños carecen de sustento debido a que existe la posibilidad de aclarar de parte del partido los elementos que sean omisiones o errores.

Posteriormente la consejera María Marván Laborde hizo uso de la palabra para mencionar que:

Con todo respeto, no veo la contradicción. A lo largo de todo el proceso se fue hablando con el partido político, se fue trabajando con él, de hecho fueron sumando una serie de pruebas, de alegatos, de discursos y no hay manera de ligar los contratos presentados con las tarjetas, por una sola razón: "Las tarjetas son innominadas". Es decir, para todo efecto práctico son efectivo.

Gracias al trabajo de la Unidad de Fiscalización y gracias al trabajo de colaboración con la Comisión Nacional Bancaria y de Valores, hemos sido conocedores hoy de dónde y cómo se dispuso de ese efectivo. Pero creo que no hay ninguna contradicción. 


\section{La consejera Marván respondió al consejero Baños de la posible}

contradicción que encontraba. Fue un proceso de trabajo conjunto en donde los contratos no se unen para dar prueba de que se entregaron las tarjetas.

\section{Posteriormente el consejero Francisco Javier Guerrero Aguirre continuó}

\section{la argumentación.}

La litis del asunto, y me refiero a la litis del asunto particular que estamos viendo, porque ya los Consejeros Electorales Alfredo Figueroa, Benito Nacif, Lorenzo Córdova y María Marván, han añadido un tema que está llegando de manera súbita a la mesa, a eso me voy a referir más adelante porque tengo diferencias con el planteamiento, aunque comentaba con el Consejero Electoral Benito Nacif que estoy virtualmente de acuerdo casi en todo, con excepción de la parte donde ellos enderezan la posibilidad de una multa que, si mis cuentas no me fallan, sería de alrededor de 75 millones de pesos. Eso es lo que están proponiendo mis colegas.

Queda claro y aquí viene, quizá, la diferencia de fondo que tengo con mis colegas y amigos que he mencionado, que desde su punto de vista estos contratos no satisfacen el destino de los recursos, eso es lo que ellos han señalado. Hacen una serie de elucubraciones y de circunstancias que ellos ponen sobre la mesa estableciendo que eso sería suficiente para establecer una multa, como ya he referido, de 75 millones de pesos.

Evidentemente no comparto ese criterio por varias razones. La primera razón es que no encuentro precedentes en la historia de la fiscalización de México donde un asunto que no ha sido conocido de manera profunda por las partes involucradas simplemente se resuelva sobre la mesa con una propuesta que están haciendo. Como resulta con frecuencia, esa propuesta se obtiene, si mis cuentas no fallan ya van cuatro votos hasta el momento que he escuchado, si obtuvieran el quinto voto pues obviamente estarían en esa ruta; pero veo varias dificultades de carácter legal en torno a esta propuesta que ellos están haciendo.

Por supuesto el quid del asunto, y lo he comentado con mis colegas, es que ellos aprecian desde su óptica, muy respetable por cierto, que esta explicación de los contratos simplemente no es satisfactoria. Toda vez que ellos estiman que no es satisfactoria, inmediatamente proceden a proponer sobre la mesa esta multa de 75 millones de pesos. En todo caso, habría también que decir que en el caso de todas las demás coaliciones, una vez que esta reclasificación que ha hecho la Unidad de Fiscalización, que por cierto acompaño, el caso de lo que el Partido Revolucionario Institucional ha señalado en su argumentación, está establecido que desde su óptica, a pesar de no sentirse obligados, están poniendo sobre la mesa una explicación sobre el destino.

El quid de esta litis reside en establecer si este argumento es suficiente o no es suficiente. Creo que en todo caso, quiero conceder razón a los proponentes, habría que quizá llevar a cabo una investigación adicional, quizá incluso un procedimiento oficioso, en todo caso. Pero lo que sí me parece que en este momento, desde mi punto de vista, no acompañaré con mi voto esta propuesta, es que al ponerse sobre la mesa en este preciso momento podrían estarse violando algunas disposiciones de legítima defensa de la parte involucrada.

\section{El consejero Francisco Javier Guerrero en su intervención resaltó que} los puntos principales del caso Monex eran el origen, destino $y$ aplicación de los recursos. Aunque dejó en claro que el asunto es necesario que hubiera una investigación más profunda. Nuevamente resalta la rapidez con la que se llevó a cabo la sesión. También 
mencionó el consejero Guerrero que con la reclasificación se podría estar violando algunas disposiciones de legítima defensa. Como se señaló anteriormente, el proceso de fiscalización que realizó la Unidad de Fiscalización conllevó un proceso donde el derecho de réplica estuvo garantizado. Otro aspecto que rescató el consejero fue el posible rebase de topes de campaña del PRI, cuestión que los otros consejeros dieron por descontado. La participación del consejero Guerrero fue valiosa porque retomó nuevamente el rebase de topes de campaña.

El representante del poder legislativo, el diputado Javier Corral preguntó lo siguiente al consejero Francisco Javier Guerrero:

Pero le voy a dar lectura muy rápida a la página 95, el estudio de fondo de la Resolución: "Del análisis de los documentos y actuaciones que integran este expediente, así como lo vertido por los representantes de los partidos políticos que integraron la otrora Coalición Movimiento Progresista y el Partido Acción Nacional, a través de sus respectivos expedientes de queja, se desprende que el fondo del presente asunto consiste en determinar el origen, el destino y la aplicación de los recursos que a través de diversas tarjetas, expeditas por Banco Monex, S.A. Institución de Banca Múltiple, Monex Grupo Financiero (en adelante Banco Monex, S.A.), fueron distribuidas por la otrora Coalición Compromiso por México (...)".

¿Después de esta lectura, usted podría sostener que está fuera de la litis de la Resolución y de la discusión el destino de los recursos?

El consejero Guerrero Aguirre respondió al diputado Corral que una revisión más profunda del caso sería más útil.

Tiene usted razón lo leí también en mi intervención, quizá no fui suficientemente claro, en la litis general del asunto sí está involucrado el asunto del destino. Quizá lo que estaría, en todo caso, sujeto a una interpretación, sería si la acreditación de estos contratos per sé serían suficientes para establecer este destino.

El consejero Guerrero mencionó en su intervención que estaba de acuerdo acerca de que también el punto del asunto es que estaban involucrados el destino de los recursos. El asunto en que puso énfasis es si los contratos eran prueba suficiente para decir a dónde fueron a parar los recursos. El punto que estableció Guerrero fue esencial debido a que cuestionó la viabilidad del contrato como comprobación del destino de los recursos. Legalmente el contrato es un elemento 
trascendente para conocer las partes firmantes y el servicio prestado pero no indica el uso del servicio. Esa es una prueba de que la normatividad precisa de elementos complementarios para llevar a cabo su propósito con mayor plenitud.

Posteriormente, el representante del PRD ante el IFE, Camerino Eleazar Márquez Madrid, le cuestionó que no se apegó la legalidad, a lo cual el consejero Guerrero mencionó que no existió una ilegalidad del PRI en cuanto al uso de los recursos.

Luego hizo uso de la palabra el representante del PRI ante el IFE, José Antonio Hernández Fraguas.

Después de la investigación de la autoridad electoral, con la disposición del Partido Revolucionario Institucional de transparentar el uso de los recursos y la colaboración de distintas instituciones públicas y privadas, queda comprobado en el expediente, de manera fehaciente, que la distribución de recursos a través de tarjetas de prepago del Banco Monex, aparte de la estructura electoral del Partido Revolucionario Institucional, durante el año 2012, tiene un origen lícito y que este origen son los propios recursos de que dispone el Partido Revolucionario Institucional provenientes del financiamiento establecido en el artículo 41 constitucional.

Queda también demostrado que la cantidad utilizada por el Partido Revolucionario Institucional en esta actividad ordinaria de sustento de su estructura electoral, fue por un monto de 66 millones 326 mil 300 pesos, lo cual fue corroborado no sólo con el contrato celebrado por el Partido Revolucionario Institucional y una empresa privada, sino también con la información oficial proveniente de la Comisión Nacional Bancaria y de Valores, dependiente de la Secretaría de Hacienda y Crédito Público, información que por cierto fuera recabada en el sexenio anterior, que concluyó su período de gestión el 30 de noviembre del año 2012.

\section{José Antonio Hernández Fraguas representante del PRI, dijo que su} partido había actuado de forma legal y se había demostrado por parte de las instituciones encargadas de verificar su legalidad.

El representante del PRD, Camerino Eleazar Márquez Madrid cuestionó al representante del PRI en lo siguiente:

Desde luego también preguntarle qué nos puede decir respecto al flujo de los saldos de prepago por parte del Grupo Comercial Inizzio, S.A. de C.V. que sumaba un total de cargas de 46 millones 179 mil 09 pesos y que estamos hablando solamente del período del 18 de abril, al período del 24 de mayo. Estamos hablando del período de campañas, estamos hablando de montos de hasta 20 millones de pesos, como se pudo acreditar el día 22 de mayo; de montos de 8 millones de pesos el día 16 de mayo y así diferentes cifras. 
Camerino Eleazar Márquez representante del PRD le preguntó a José Antonio Fraguas sobre las inconsistencias sobre los datos presentados por el PRI, debido a que en un día se usaron varios millones de pesos. El representante del PRD puso de nuevo en evidencia que existía una falta de revisión acertada de los recursos.

\section{A lo que el representante del PRI, dijo que:}

También como ha quedado claro, y ya lo dejé suficientemente establecido, mi partido político no celebró ningún contrato con ninguna otra empresa que no sea Alkino, por lo tanto, desconocemos cualquier situación que pudiera haberse desarrollado de carácter contractual, por supuesto, con las otras empresas mencionadas. Con esto espero, señor representante, dar respuesta a sus preguntas.

La respuesta del representante del PRI volvió a reiterar la inocencia del partido y que no sabía de algún otro contrato.

\section{Posteriormente el representante del Poder Legislativo, Javier Corral} Jurado, cuestionó al representante del PRI.

¿Cuál es el control que el Partido Revolucionario Institucional tuvo sobre el destino del dinero? Porque se ha afirmado que en realidad este dinero sólo fue orientado a 13 estados de la República, e incluso sólo en uno, entiendo que en el estado de Hidalgo, se ejerció el 26 por ciento de estos recursos. ¿Qué sucedió o qué pasó en las otras 19 entidades?, ¿Cuál es el control que el Partido Revolucionario Institucional tiene de esto?

Pero a 13 Estados fue ese dinero, ¿Qué pasó con los otros Estados del país?, ¿Cuál es el control que se tiene de ese dinero?

Javier Corral cuestionó al representante del PRI sobre el control que tenía el partido sobre los recursos. Esa pregunta estaba dirigida a sondear el manejo que hizo el PRI de los recursos. Es importante notar que con esta interrogación buscaba dar indicios de que el PRI sí sabía cómo se había manejado el dinero pero que lo negaba presentando comprobantes ante la autoridad electoral.

\section{A lo que José Antonio Hernández Fraguas dijo que:}

\footnotetext{
Mi partido político definió darle prioridad al cuidado y a la vigilancia del desarrollo del Proceso Electoral Federal en estas tres entidades, y por eso definió que los recursos que fueron destinados con el pago de estas tarjetas, con las tarjetas Monex, fuera aplicable solamente en estas tres entidades. Las razones son internas que los partidos políticos tienen para poder saber a dónde fortalecer su estructura electoral y a dónde fortalecer su capacidad de vigilancia de los procesos electorales.
} 
La contestación del representante priísta procuró no entrar en el punto que buscaba tratar el consejero del poder legislativo.

\section{Después el representante del poder legislativo, Fernando Belaunzarán,} continuó con los cuestionamientos al PRI.

¿Por qué Alkino que no se dedica a las tarjetas prepagadas? Si el Partido Revolucionario Institucional quería tarjetas prepagadas, por qué no va a una institución que se dedique a hacer las tarjetas prepagadas, y va a una empresa que se dedica a otra cosa.

Segunda pregunta: ¿Si cuando fueron con Alkino, Alkino les dijo y les comentó que no tenía dinero para fondear esas tarjetas? O sea, no se dedica a las tarjetas. La pregunta es si ¿También ustedes estaban enterados de que Alkino no tenía recursos? Es decir, cuando uno busca una empresa, si dices: "Quiero 66 millones de tarjetas prepagadas". Uno tiene que preguntarse dos cosas: Que se dedique a eso, a hacerlas prepagadas, y dos, que tenga los recursos para hacerlo. ¿Por qué Alkino, si Alkino les comunicó que no tenía ese recurso y tenía que subcontratar?.

El consejero del poder legislativo Fernando Belaunzarán realizó semejantes cuestionamientos a sus anteriores participaciones sobre la incoherencia de la actuación del PRI para pedir un servicio a una empresa que no tenía recursos.

\section{El representante del PRI, José Antonio Hernández Fragua contestó lo} siguiente:

¿Por qué Alkino? En el objeto social de esta empresa aparece que se dedica a la fabricación de estas tarjetas y no podemos definir exactamente por qué no quedó claramente establecido que no tenía los recursos suficientes.

El representante del PRI respondió solo una parte de la pregunta formulada por el diputado Fernando Belaunzarán. La parte del cuestionamiento del dinero que no poseía la empresa la dejó sin contestar. Luego participó el consejero del poder legislativo, Ricardo Astudillo Suárez para hablar someramente sobre el caso.

\section{Posteriormente Sara Castellanos Cortés, representante del PVEM,} mencionó que:

La conclusión es tajante, no se recibieron aportaciones de personas morales, porque el dinero que se estaba manejando era de las prerrogativas del partido político y las empresas prestaron un servicio de distribución. Los datos desacreditan el 
dicho de los denunciantes, en el sentido de que diversas empresas hayan aportado recursos con la finalidad de pagar la emisión de tarjetas y la dispersión de recursos.

El Partido Revolucionario Institucional contrató un servicio de dispersión de recursos, adquiriendo tarjetas de prepago y cubriendo en su totalidad las obligaciones pactadas con la empresa referida. Todos los pagos fueron depósitos y transferencias que se efectuaron a través de operaciones dentro del propio sistema bancario.

La representante del PVEM hizo énfasis en la legalidad de los recursos porque dijo que los recursos que manejó el partido eran priístas. Solamente la empresa se contrató para la dispersión de los mismos. Además de que la desacreditación de las quejas presentadas por el PRD y PAN eran evidentes.

Posteriormente, el consejero del poder legislativo Ricardo Mejía Berdejas hizo una crítica a la actuación de la Unidad de Fiscalización.

\author{
Por nueva ocasión consejero Marco Antonio Baño Martínez hizo uso \\ de la palabra para responder a las comentarios hechos por el diputado \\ Ricardo Mejía Berdejas, donde dijo que:
}

Pero voy a un punto fino aquí, y me voy a referir a la propuesta de los Consejeros Electorales Benito Nacif, Lorenzo Córdova, Alfredo Figueroa y María Marván, no puedo acompañar esa propuesta y no la puedo acompañar por una simple y sencilla razón, es una propuesta que suena, en términos estéticos, a una intención de fundar por fundar el procedimiento.

No hay un argumento de fondo y voy a decir por qué: Porque la Unidad de Fiscalización, cuando hizo la revisión de la información que proporcionó el Partido Revolucionario Institucional con relación a este tema, reclasificó el gasto, reclasificó la característica del gasto realizado a través del tema de Monex y dijo: "No se trata de gasto ordinario, sino de gasto de campaña". Pero eso proviene de una decisión de la autoridad. Luego, después decimos, para fundar, al menos en la perspectiva de mis colegas que lo han propuesto así, que no se comprobó el destino de esos recursos, no se puede comprobar de esa manera, porque la forma en que fue planteada la información proveniente del partido político había considerado esta parte, vamos a ver cómo los demás partidos políticos hicieron algo parecido, pero esta parte venía asignada a los gastos ordinarios.

Un acto de autoridad ha generado una reclasificación de ese gasto y correctamente se está sumando a los topes de gastos de campaña. Quererlo fundar de esa manera, y lo digo con todas sus letras, sería violatoria de garantías. Aquí se estaría vulnerando el tema de las garantías procesales para que se pueda hacer la comprobación correspondiente.

Por eso no puedo acompañar, bajo ninguna consideración, la propuesta que mis colegas están formulando con relación a este tema. Ni siquiera ha habido una reflexión respecto a simple y llanamente que no hay un planteamiento de parte del partido político involucrado, compruebe fehacientemente el destino de estos recursos; tampoco ha habido sobre la mesa, de parte de mis cuatro colegas, supongo que ellos ahondarán en su propuesta en la segunda intervención, pero no hay argumentos para sustentar la propuesta en el sentido de que debería ser fundado por no haberse aclarado correctamente el destino. La verdad es que lo demás es discurso.

\title{
El consejero Marco Antonio Baños en esta intervención volvió a
} mencionar que la reclasificación violaba las garantías que tenía el PRI. 
Este tópico ya lo había mencionado. Lo interesante es que mencionó en esta ocasión que se debían de sumar a los gastos de campañas para ver si se rebasó el tope de gastos de campaña. Por otra parte también dijo que no estaba aclarado el destino de los recursos utilizados por el PRI. Aunque sea paradójica la participación del consejero Baños vislumbró el tema de rebase de topes de campaña al igual que el consejero Guerrero, y que no estaba dentro de proyecto de resolución.

\title{
Fernando Belaunzarán Méndez le argumentó al consejero Baños lo
} siguiente:

\begin{abstract}
El argumento básico para determinar que los gastos de la estructura electoral son de gasto ordinario, es que se realizan posteriormente a que concluye la campaña electoral, que es dos días antes del proceso. Entonces se les paga. Nada más le quiero preguntar al Consejero Electoral Marco Antonio Baños si cree que eso tiene lógica, en el caso del Partido Revolucionario Institucional, cuando los pagos se dieron desde el mes de abril, con gran anticipación al día de la Jornada Electoral, cuando está establecido que cobró 18 mil 700 pesos más o menos un representante general, si cree que eso es lógico por un día de trabajo, el día que se da, dos días después de concluida la campaña.
\end{abstract}

Si eso es creíble, 18 mil 700 pesos más o menos, que el testimonio es que cobraron los representantes generales por un día de trabajo. El Reglamento de Fiscalización sólo habla de créditos con la Banca Comercial y pone requisitos estrictos y requisitos para informar, etcétera y prohíbe con la Banca de Desarrollo. El Reglamento de Fiscalización es más bien restrictivo, en la lógica de fiscalización, los sistemas son restrictivos, no es permisivo. ¿En qué se basa para decir que el Reglamento permite créditos con empresas mercantiles, si no están establecidos en el Código Electoral y sólo habla de Banca Comercial?

\section{El consejero Marco Antonio Baños respondió lo siguiente:}

Ya el tema fundamental ahí fue la temporalidad en la que se suscribieron los contratos dentro del período de campaña. Toda esa parte fue lo que la Unidad de Fiscalización ha tomado como base para reclasificar el gasto. Con eso no tengo diferencia, así que no veo la razón, honestamente, de la pregunta ni del diferendo.

La otra parte, no está prohibido, dígame usted dónde está prohibido. La ley y el Reglamento no dicen: "Debe", dice: "Podrán". Es potestativo también. La única prohibición expresa es la que tiene que ver para la suscripción de esos contratos con la Banca de Desarrollo. El Reglamento lo que hace, ciertamente, es poner criterios y elementos que deben actualizarse cuando se hagan ese tipo de contrataciones con la Banca.

La participación del consejero Marco Antonio Baños mencionó que no existía diferencia con la anterior intervención del diputado Belaunzarán porque los contratos fueron realizados en el periodo de campaña. Por otra parte, la mención que hizo del artículo 123 del reglamento de 
fiscalización donde no se dice acerca de contratos con banca comercial. Cuando no existe un artículo donde se mencione el caso como lo es el de Monex, se debió de recurrir a retomar el espíritu de la ley con respecto a que no se debe de afectar los valores básicos de la democracia. Esto es, si la participación de una empresa mercantil realiza un financiamiento a un partido, aunque no esté explícitamente escrito en la ley, si viola el principio básico de legalidad en una contienda se puede declarar ilegal.

El representante del PRD ante el IFE, Camerino Eleazar aportó lo siguiente al debate:

En ningún apartado del Código Electoral se establece que está permitido solicitar un crédito a una sociedad mercantil. Está permitido contratar servicios y las cuentas por cobrar se pagan. Eso es diferente a ir a contratar un financiamiento de dudosa procedencia, de cuantías que no es sostenible objetiva y racionalmente que esas empresas sean solventes.

Por eso incurrimos en una actitud probablemente de encubrimiento y eso genera una consecuencia de absoluta inequidad e ilegalidad. Creo que estamos ante un hecho verdaderamente trascendente. Por eso me parece que sí deberíamos declarar fundada esta Resolución, toda vez que también la cantidad de facturas Monex que tenemos y que incorporamos al expediente y que no se atienden, estamos nosotros estableciendo que para la empresa Inizzio S.A. de C.V. hay más de 20 facturas que debe establecerse de dónde surge este dinero.

El representante del PRD, Camerino Eleazar Márquez mencionó que no existe un elemento en la normatividad que permita pedir un crédito a una empresa mercantil y aunque no hay una artículo en específico que prohíba este aspecto, solo dice que se puede solicitar un servicio. Retomando los comentarios hechos en la anterior intervención del consejero Baños, que no haya una reglamentación no impide que se extrapole elementos de otras leyes al caso en particular. También dijo que se podría establecer el delito de encubrimiento, aunque no se trató en el proyecto se pudo haber investigado si hubo esta infracción. Sin embargo, esta facultad no la posee el IFE de castigar fuera de su ámbito electoral. 


\section{El consejero Baños le preguntó al representante del PRD.}

Pero él lo equipara a la contratación de un financiamiento. ¿Bajo qué argumento puede sostener técnica, jurídica, contablemente, como válido eso? .

\section{La contestación del Camerino Eleazar fue que:}

Pero, quiero referirme a la página 197, en el último párrafo hace referencia justamente a un servicio financiero. No fueron a prestar un servicio para arreglar los teléfonos del Partido Revolucionario Institucional, fueron a dar unas tarjetas, que luego fueron a utilizar en Zara y en otras empresas mercantiles porque por cierto, tienen esos detalles.

El representante del PRD, respondió aunque sin emplear elementos jurídicos. Solamente se basó en la investigación realizada por la Unidad de Fiscalización. La contestación fue clara y precisa debido a que en el documento enviado por el PRI, dejó de forma escrita que fue un financiamiento. Este hecho muestra que probablemente el consejero Baños no había leído el proyecto de resolución completo. El proyecto fue entregado dos días antes del 23 de enero. Resalta que la premura con que discutió este caso generó que hubiera de parte de algunos consejeros desconocimiento del algunos aspectos técnicos y legales del asunto. También es importante destacar que la omisión de sus deberes laborales se dejó entrever en esta participación.

\section{Javier Corral Jurado tomó la palabra y mencionó que:}

Es claro que se contrató, además del servicio de dispersión del dinero, un financiamiento, toda vez que nunca antes fue alimentada la cuenta. Pero quiero ir al fondo de la cuestión. Quiero ir y no calificar, con buena o mala voluntad, a quienes insisten en fincar en un contrato la justificación del destino de los recursos, que me parece que éste es el tema medular. Por supuesto que no se prohíbe ni está restringido, salvo en un caso en la ley el poder contratar con empresas mercantiles servicios los partidos políticos.

Que el partido político puede contratar directamente. Claro que sí, ¿Y por qué triangularon? Esta es la pregunta fundamental, ¿Y por qué se trianguló? Incluso con empresas con múltiples deficiencias no solamente económicas, sino de objeto social y de socios e incluso de omisiones fiscales en sus declaraciones estratégicamente ausentes, una de ellas en el mes de julio y la otra sin Ejercicio Fiscal en el año 2011.

Si podía contratar el Partido Revolucionario Institucional directamente, ¿Por qué se ha hecho toda esta, no triangulación sino piramidación? Si lo podían hacer directamente, porque es evidente que cuando estalló el escándalo tenían la alternativa o de reconocer aportaciones privadas, y eso obviamente violenta el límite de ingresos permitidos por la legislación en materia de financiamiento privado y se tuvo que reconocer, como aquí lo hemos escuchado que era financiamiento público. 
No me pueden decir ahora que el contrato garantiza el destino de los recursos cuando el mismo Coordinador de la campaña había negado que los usaran. Los contratos hay que ubicarlos en el texto, en el contexto para eliminar el pretexto.

\title{
El diputado Javier Corral Jurado puso en la discusión el punto de que
} fue un financiamiento debido a que la cuenta nunca se depositó efectivo en la misma. El consejero del poder legislativo hizo uso de la lógica que es preciso que haya en una investigación. Es preciso que en una pesquisa y decisión que posteriormente se tomé por parte de un individuo que actúe como juez, esté fundamentada en las pruebas confirman o refutan hipótesis. Además que las pruebas dan validez o contradicen a los dichos de las partes que integran un caso. Este argumento que se mencionó anteriormente es el aspecto normativo de la actuación del juez. Sin embargo el diputado Javier Corral puso en evidencia la coherencia que daba a sus argumentos y realizó un proceso que era menester que hicieran los consejeros electorales.

\section{Luego habló la consejera María Macarita Elizondo Gasperín.}

En el Proyecto de Resolución, se sostiene que los pagos realizados por las diversas empresas, de estos grupos, a la cuenta del Grupo Comercial Inizzio en Banco Monex fueron producto de distintas relaciones contractuales entre sociedades legalmente constituidas.

Resulta insostenible, a mi juicio, por ejemplo, un razonamiento, en el sentido de que está prohibido a los partidos políticos, aspirantes, precandidatos, candidatos, aceptar aportaciones o donaciones en efectivo o en especie de iglesias o agrupaciones religiosas, pero sí pueden recibir préstamos o créditos de ellos. Tampoco sería admisible señalar que un partido político está impedido para recibir una aportación en especie de un partido político extranjero, pero sí préstamos de dinero o créditos de dichas organizaciones.

Ambas cuestiones llevan al absurdo y son un sustento que no puede tener base. Por lo tanto, motiva mi reflexión. Consecuentemente, considero que la prohibición que establecen los sujetos impedidos para realizar aportaciones o donativos de los partidos políticos, aspirantes, precandidatos y candidatos, configura un mandato general que precisa los tipos de financiamiento prohibidos expresamente por la ley.

\begin{abstract}
Ahora bien, se sostiene en el Proyecto de Resolución que la contratación de un servicio para el diseño de una estrategia que permitió al partido político presunto infractor dispersar recursos durante la campaña, como lícitos, en mi concepto existen normas que se omitieron examinar en cuanto a su dimensión y alcance, y que una diversa interpretación de éstas podría conducir a considerar la utilización de instrumento que impide y obstaculiza el debido ejercicio de una facultad fiscalizadora de este Instituto Federal Electoral.
\end{abstract}

Tal como se razona en el Proyecto de Resolución, la contratación de un servicio para el diseño de una estrategia de dispersión de recursos, entraña en sí mismo un contrato de mutuo con interés; esto es, un préstamo o un crédito a favor del partido político presunto infractor, que le permitió dispersar recursos durante la campaña presidencial.

Hay mucho a mi juicio a establecer como fundamentación y motivación de este expediente y debe llevarse una interpretación armónica y funcional de los artículos 41, Base II de la Constitución Política; 77, párrafos 2 y 3, inciso g) del 
Código Federal de Instituciones y Procedimientos Electorales, así como los artículos 52 y 53, del propio Reglamento de Fiscalización. Con claridad, la posibilidad de que los partidos políticos contraten créditos pero única y exclusivamente con instituciones financieras, lo que deberá efectuar de manera directa, a mi juicio debe ser así y no a través de intermediarios. De esta manera no es factible que a través de un intermediario o varios se pueda allegar de recursos provenientes de eso, por lo cual me separo por otras razones de lo argumentado por mis propios colegas y me esperaré a la segunda intervención, a que precisen, en su caso, la individualización de la sanción.

\section{La consejera María Macarita Elizondo resaltó la contradicción que} existe entre la ley no permite que haya donaciones o aportaciones de entes como iglesias, empresas pero sí pueden recibir préstamos aunque la normatividad no lo expresa. La motivación o espíritu de la ley en materia de financiamiento de entes privados veda la participación de privados en la contienda electoral, sea por donaciones, aportaciones o préstamos. La interpretación que se debiera hacer sería seguir el fundamento que se pone en escrito en la norma. El argumento que propuso la consejera Elizondo dio cuenta de la interpretación armónica de varias leyes para dar por resultado una visión amplia de la ley.

\section{Luego el consejero Alfredo Figueroa Fernández hizo uso de la} palabra.

Porque lo que aquí estamos discutiendo es si existe o no existen elementos que permitan a la autoridad electoral establecer con toda claridad si se comprobó o no se comprobó el destino de esos recursos en un conjunto de elementos que están presentes. Se ha hablado por cierto de reclasificación.

No, nadie está reclasificando un gasto. Lo que ha ocurrido es que un partido político dice que ese gasto estaba orientado a lo ordinario y en la investigación de un procedimiento sancionador de carácter fiscal, de fiscalización, lo que se ha acreditado es que ese dicho no puede sostenerse por un conjunto de razones, entre las que está cómo el dinero fue ejercido en cada uno de esos momentos y si se acompaña la idea de que esos recursos fueron ejercidos durante el período de campaña, debe acompañarse la idea de que esos contratos con las personas a las que se les estaba prestando un determinado servicio, esas personas no tienen que ver con los recursos que aquí se establecen y por lo tanto, en la consistencia de la argumentación de la propia Unidad de Fiscalización en términos de la clasificación del gasto, está en cuestión frente al Consejo General, cuando este lo que hace es analizar los méritos de los elementos que tenemos sobre la mesa.

Este es el fondo de la discusión que hoy estamos manteniendo aquí junto con, desde luego, la preocupación de si una empresa mercantil puede financiar o no puede financiar, evidentemente merced a una interpretación que no puede ser sino armónica y sistemática, de lo que dice la Constitución Política, la ley y nuestro propio Reglamento, porque no hay expresamente una prohibición en la reglamentación de carácter electoral, pero desde luego sí una diferencia de interpretación. Este es el fondo de esta circunstancia y por lo tanto, no hay un deseo de establecer la fundamentación.

\section{El consejero Alfredo Figueroa ofreció el argumento contrario al que venía mencionando el consejero Baños, es decir que no se había violado}


el derecho de réplica del PRI. Sin embargo, el consejero Figueroa dijo que aunque el partido había presentado sus pruebas para contabilizar los gastos ordinarios pero la Unidad de Fiscalización había demostrado que fueron usados de manera distinta. Por otra parte, el consejero Figueroa dijo que los recursos fueron asignados a los representantes generales y las tarjetas y por tanto no existió un contrato. Por tal motivo, era fundado el proyecto contra el PRI. Los argumentos brindados por el consejero Figueroa poseyeron claridad y certeza.

\section{Lorenzo Córdova Vianello tomó la palabra para decir que:}

Creo que los contratos, lo que prueban es la existencia de dos voluntades coincidentes, en prestar un servicio por un lado y, en remunerarlo por el otro. Pero, sigo insistiendo que sería mal mensaje hacia el futuro, si aceptáramos los contratos como mecanismos de comprobación de las erogaciones que realizan los partidos políticos.

Llama la atención no solamente que no todos los contratos estén respaldados por un recibo, sino que también como ocurre con el que tengo aquí en la mano, un contrato firmado el 13 de diciembre de 2011 tenga anexo un recibo fechado, un comprobante de que se recibió por parte de uno de los contratantes, el dinero, el 31 de marzo de 2012 cuando el primer fondeo del que da cuenta la investigación a las tarjetas Monex es del 2 de abril de 2012. Es decir, está fechado antes. Evidentemente no estoy poniendo en duda la legalidad de estos documentos, evidentemente esto respalda una erogación, un pago hecho por otra vía, en efectivo tal vez, no lo sé, pero no con los monederos Monex porque no es congruente con lo que la investigación nos revela.

En síntesis, creo que es necesario una comprobación adicional que respalde lo que dicen los contratos, y eso es lo que no tenemos.

\section{El consejero Lorenzo Córdova mencionó que sentaría mal precedente} si aceptaran a los contratos como prueba del gasto de los recursos. Ese aspecto es trascendente debido a que a pesar de que se entregó los contratos sin embargo se procuró ocultar otro suceso. A este caso, es preciso mencionar "no es creíble esperar que las eventuales grandes irregularidades sean descubiertas y cabalmente conocidas y esclarecidas a través de los instrumentos directos de control (especialmente la auditoria), pues la irregularidades no suelen reportarse". ${ }^{164}$ Para el caso de Monex, el PRI sí presentó contratos pero con la finalidad de desviar

\footnotetext{
${ }^{164}$ Lujambio, Alonso. "La fiscalización de los gastos de los partidos políticos". En Zovatto, Daniel, Dieter Nohlen (comp.). Tratado de derecho electoral comparado en América Latina. 2da. Edición. FCEIFE-IDEA Internacional y Tribunal del poder judicial de la Federación. México. 2007. Pág. 826.
} 
la atención de la autoridad electoral. Un elemento que presentó el consejero Córdova fue la incompatibilidad e incongruencia de las pruebas presentadas por el PRI porque se dio un recibo antes de que se hiciera un pago.

\section{El consejero Benito Nacif Hernández hizo uso de la palabra para} decir que:

Creo que, a estas alturas del debate, las dudas que se han planteado respecto a la posición que hemos puesto sobre la mesa la Consejera Electoral María Marván y los Consejeros Electorales Lorenzo Córdova, Alfredo Figueroa y el de la voz, una tiene que ver sobre si el Partido Revolucionario Institucional tenía la obligación de acreditar el destino y la aplicación de estos recursos..

Por esa razón, creo que parece ser una regla formal, tiene una enorme importancia para proteger la integridad del sistema de fiscalización, porque básicamente lo que hace el Partido Revolucionario Institucional es tratar de acreditar el destino de esos recursos con contratos que son documentales privadas, documentales privadas que no concuerdan con las documentales públicas que tenemos que, en este caso, son los informes que pasa la Comisión Nacional Bancaria y de Valores respecto al destino de esos recursos.

Son dos fuentes de información que se contradicen, que no se confirman unas a otras y que no hay una aclaración, el dinero va por un lado y los contratos por otro. Nunca hay un vínculo claro entre estos dos elementos y, me parece que, esa falta formal tiene una enorme repercusión, como la de origen que es no haber reportado lo que es claramente un préstamo, que es una obligación establecida en el Reglamento, el Reglamento dice: "Lo tienes que reportar cinco días hábiles después de haberlo firmado"; y si hay una reestructuración también tienes que reportarlo.

¿Por qué existe esa regla formal? Para que reconstruyas una historia si alguien presenta una denuncia y entonces trates de justificar algo que la regla te obliga a dar esa información a la Unidad de Fiscalización y tiene una enorme importancia porque precisamente esas reglas buscan evitar que se generen esquemas de financiamiento paralelo que si se denuncian no puedas reconstruir documentos para después sostener que ese financiamiento fue legítimo.

Benito Nacif mencionó en su intervención que el PRI no actuó de manera que especifica la fiscalización pública. Presentó unos contratos que vinieron de documentos privados. Esto generó que hubiera una disparidad en las investigaciones realizadas hechas por la Comisión Bancaria de Valores. Además de que el PRI violó las disposiciones que establecen el reglamento de fiscalización. El aspecto más importante que dijo el consejero Nacif fue que la regla formal ayuda a reconstruir la historia del proceso. El consejero hizo uso de la facultad que posee un juez en el derecho, la habilidad de reconstruir el curso del caso. Esto es usar la lógica jurídica.

El representante del PAN Rogelio Carbajal Tejada dijo lo siguiente: 
Pregunta el Consejero Electoral Marco Antonio Baños que ¿Con base en qué se puede catalogar este contrato como un financiamiento? Pues con base en el objeto del contrato.

Con base en esto, se puede definir que esto es un financiamiento, no ir a comprar un folleto o pedir la impresión de un documento o montar un espectacular, que eso podría catalogarse como la prestación de un servicio. Me podrán decir, claro, prestar dinero también es un servicio. Sí, es prestar un servicio financiero, es un financiamiento. Vaya, para no ahondar en la discusión, voy a leer lo que contestó el Partido Revolucionario Institucional a la queja, foja 74 del Proyecto de Resolución. Dice, segundo párrafo de la foja 74: "En lo que se refiere al financiamiento recibido por el Partido Revolucionario Institucional de parte de Alkino, Servicios y Calidad, S.A. de C.V. por un monto de 66 millones 326 mil 300 pesos..." ". No sigo más la cita, es decir, el contrato lo dice, el partido político lo acepta, es un financiamiento.

\section{$\mathrm{Al}$ igual que para otros representantes de partido, para el del PAN,} Rogelio Carbajal, se trató de una financiamiento. Rogelio Carbajal leyó un extracto del proyecto de resolución donde el PRI en un documento entregado a la Unidad de Fiscalización reconoce que fue un financiamiento. Carbajal no hizo uso de elemento legales para mostrar que fue un financiamiento. Únicamente investigó los elementos que poseían el proyecto de resolución. La participación del representante del PAN, fue adecuada y precisa.

\section{El diputado Fernando Belaunzarán Méndez tomó nuevamente la} palabra.

Estamos ante un gasto de campaña ilegal a través de una cuenta ilegal, que se pretende ocultar con el contrato de un crédito ilegal, que se dio a conocer después de negarlo y una vez concluido el Proceso Electoral Federal. Hecho, este crédito ilegal, con una empresa mercantil no idónea para otorgarlo y sin solvencia, que a su vez contrata a otra empresa mercantil en la misma situación, la cual también contrata a otra empresa "ídem". Ante eso estamos.

Algo que es preocupante, no abran el expediente de los créditos con empresas mercantiles, en condiciones, por cierto, mucho más favorables que en la Banca Comercial, como es el caso que nos ocupa, solamente por salvar al príncipe.

Estamos ante un fraude a la ley que se quiere justificar con otro fraude a la ley y esto, me parece, no lo debiéramos aceptar, porque no tiene, insisto, la menor lógica que alguien vaya con una empresa sin recursos a pedirle un préstamo, simplemente para lavarse las manos y no saber cómo pasó.

\section{El consejero del poder legislativo, Fernando Beluanzarán habló de la} ilegalidad del caso desde el origen, el prestatario. También mencionó que la tara se intentó cubrir con otro ardid. 


\title{
El consejero Alfredo Figueroa Fernández deseó saber que pensaba al
}

\section{diputado Beluanzarán sobre un asunto.}

Mi convicción en torno al particular la expreso y quiero saber su opinión, es que desde luego en relación a la característica de declarar fundado la no comprobación de recursos, ese monto no puede incorporarse por una razón: porque está comprobado que se pagó para esos intereses.

Es decir, no incorporarlos en la sanción por no comprobación de destino, está comprobado el destino, pero sí incorporarlos como el costo de gasto de campaña que representó un proceso de financiamiento en esa dirección. Por su opinión en relación al particular y su respuesta, Muchas gracias.

El consejero Figueroa propuso que no se declara fundado la no comprobación de recursos debido a que sí se supo el destino del dinero. Por tanto, era preciso que se sumaran a los gastos de campaña. Es interesante la propuesta que realizó el consejero Figueroa.

\section{El consejero del poder legislativo respondió:}

\begin{abstract}
Ahora, el Partido Revolucionario Institucional paga, pero lo cierto es que quien fondea la cuenta de Inizzio, que es la que va a los bolsillos de los representantes generales, son empresas mercantiles y eso viola claramente el Código Electoral, pero lo paga el Partido Revolucionario Institucional como diciendo, sí lo pusieron ellos o quien sea, me lavo las manos, pero al pagar me libro de toda responsabilidad.

Todos sabemos, si nos hacemos esta pregunta en privado y en conciencia, todos tendríamos la misma respuesta si decimos: ¿si no hubiera estallado el escándalo el Partido Revolucionario Institucional hubiera reportado de esa cuenta que está a nombre de Inizzio y hubiera pagado el dinero? Creo que todos nos contestamos lo mismo, en privado, en conciencia. Pero el caso es que lo pagó, porque después de estallado el escándalo y después de negarlo, no, Me parece que la falta no se borra simplemente porque uno paga, sobre todo cuando fue "atrapado en la movida".
\end{abstract}

La coartada que realizó el PRI, mencionó el diputado Belaunzarán, fue por medio de un préstamo que hizo Inizzio pero que finalmente pagó el PRI. Las disquisiciones hechas por el consejero Belaunzarán resultaron sugerentes para la discusión.

\section{Ricardo Mejía Berdejas, representante del poder legislativo también} hizo uso de la palabra.

el Partido Revolucionario Institucional fue pillado, fue sorprendido con toda esta madeja que se fue deshilvanando a partir de los operadores del estado de Guanajuato y todo lo que fue surgiendo.

Tan fue pillado que en un primer momento y de bote pronto Luis Videgaray lo niega, lo niega el vocero y luego ya, ante la evidencia de los hechos y para tratar de hacer un conteo de daños, sale a la palestra el hoy Procurador General de la República, Jesús Murillo Karam. Pero, evidentemente había una intención de evadir, de engañar, de ocultar una operación de financiamiento ilícito que estaba haciendo el Partido Revolucionario Institucional y aquí creo que está cuadrado que tiene que haber evidentemente una sanción. 
Primero, porque si hubo el financiamiento, que es evidente que fue un préstamo y aquí coincido con el representante del Partido Acción Nacional, que aunque diga arrendamiento, "si tiene cola de pato, camina como pato y grazna como pato, es pato".

Entonces esto fue un préstamo, es evidente y fue un préstamo no reportado al Instituto Federal Electoral y ya ese solo hecho ameritaría una sanción. Por otro lado, está el tema del destino del gasto y por otro lado, está también la violación al principio de equidad.

\section{El consejero del poder legislativo Berdejas expuso argumentos sobre la} violación de la normatividad en fiscalización en materia electoral que realizó el PRI. Además de que insistió en que fue un financiamiento que recibió el PRI.

\section{El representante del PRI José Antonio Hernández Fraguas dijo lo} siguiente:

Nosotros seguimos insistiendo en que este es un gasto ordinario y no gasto de campaña, toda vez que, si se estaba pagando a una estructura electoral y la estructura electoral actúa principalmente el día de la jornada, en el día de la jornada ya no hay posibilidades de hacer proselitismo, porque si alguno de los representantes lo hiciera, incurriría incluso en un delito electoral y podría hasta anularse la votación de la casilla, si es que se estuviera promoviendo el voto en ese momento.

Nosotros sí hemos considerado desde las primeras diligencias practicadas en el expediente, así como en la contestación al emplazamiento, alegatos y vista del asunto, que en los gastos realizados por el Partido Revolucionario Institucional y pagados en carácter de honorarios asimilados a salarios, aparte de nuestra estructura electoral, son de carácter ordinario y no de campaña. Sin embargo, en la secuela del procedimiento, atendiendo a los requerimientos de la autoridad fiscalizadora, entregamos la comprobación de la totalidad de lo erogado por el mencionado concepto, mismo que fue escrupulosamente revisado por la Unidad de Fiscalización.

Si este Consejo General determina hoy que los gastos referidos son de campaña, la Unidad de Fiscalización, que ya tiene la comprobación, tendrá que computarlos en ese rubro. Pero insisto, es hasta el día de hoy en que esta autoridad está determinando que son gastos de campaña. El artículo 346 del Reglamento de Fiscalización, establece: "Si durante la revisión de los informes, la Unidad de Fiscalización advierte la existencia de errores u omisiones técnicas, lo notificará al partido político, Coalición, Agrupación Política, Organización de Observadores u Organización de Ciudadanos que hubiere incurrido en ellos, según sea el caso, para que en un plazo de 10 días, contados a partir de dicha notificación presenten la documentación solicitada, así como las aclaraciones o rectificaciones que estimen pertinentes".

En este caso la Unidad de Fiscalización, pese a contar con toda la información contable del caso Monex, nunca notificó a mi partido político que omitió dicha comprobación de gastos en su campaña. Ahora, sin el cumplimiento de ese requisito, se pretende establecer una sanción violando el principio de legalidad y debido proceso.

\section{José Antonio Hernández Fraguas reiteró la legalidad del gasto de campaña que presentó el PRI ante la Unidad de Fiscalización. Además el representante del PRI dijo que la reclasificación de gastos ordinarios que realizó la Unidad de Fiscalización era una omisión de la Unidad.}


La argumentación de José Antonio Hernández Fraguas omitió un hecho relevante, el Consejo General no tiene facultades legales para reasignar los gastos que presentó el PRI. La única instancia que genera el proceso de fiscalización es la Unidad de Fiscalización que cuenta con autonomía de gestión por lo que el Consejo General no puede recomendarle cómo realizar sus labores. $\mathrm{La}$ intervención del representante del PRI trató de encartar a los consejeros aunque sus argumentos no tenían el adecuado respaldo.

\section{El consejero Baños nuevamente tomó la palabra.}

Porque si es, desde mi punto de vista, válido la suscripción de los contratos mutuo con empresas. Por una razón sencilla. Primero, porque no está prohibido. En segundo lugar, porque el objeto de esos contratos no es una aportación, no consiste en un financiamiento como se ha querido decir en esta mesa, no se trata de una aportación a favor de un partido político ni de un donativo, sino de una cantidad que, en su caso, regresaría a la propia empresa.

Puede ser un préstamo, pero se trata de un recurso que no está siendo donado al partido político, que no está sirviendo para un financiamiento bajo la modalidad que se ha querido decir aquí. Creo que en esa parte no hay vuelta de hoja.Toda esa argumentación que se expresó respecto a que sólo se puede con instituciones bancarias, desde mi punto de vista, no se sostiene; y no se sostiene porque ya ha habido interpretaciones en otro sentido que han validado este criterio.

Ahora, desde mi punto de vista sigo considerando que es inadecuado el hecho de aprobar esta propuesta formulada por mis colegas, en el sentido de que esto se debe de declarar fundado. Claro que está fundado, está fundado para efectos de los topes de gastos de campaña, sería absolutamente incorrecto decir que la queja no se está declarando fundada, se está declarando infundada para efectos específicos de las aportaciones ilegales de empresas mercantiles, que ese era uno de los motivos de la Litis.

El consejero Baños afirmó que existía validez en la realización de contratos entre la empresa y el partido. También dijo que no era un financiamiento ni un donativo. Además dijo que se había hecho interpretaciones que validaban el financiamiento con otras empresas que no sean bancarias, aunque no especificó cuándo sucedió este suceso. Este argumento que expuso el consejero Baños dejó entrever que han existido violaciones a la normatividad en el rubro de fiscalización de financiamiento con otras empresas que no sean bancarias. La participación del consejero Baños con respecto a este último punto es 


\title{
relevadora porque descubrió ilegalidades que se habían cometido
} anteriormente en esta materia.

\section{El diputado Fernando Belaunzarán, polemizó con el consejero Marco}

\author{
Antonio Baños, al respecto dijo:
}

Primero, usted menciona que si es préstamo no es financiamiento, pero la verdad es que los préstamos también sirven para financiar. Si uno compra un carro y pide un crédito bancario, ese préstamo te sirve para financiar, y así se dice. Si pedimos préstamos el país los hace para financiar distintas obras.

Me parece que, simplemente hacerle la aclaración de que las aportaciones pueden servir para financiar, pero también los préstamos. En este caso sirvió para financiar actividades de un partido político, este préstamo.

Quiero ver si estaría de acuerdo con esa interpretación. Segundo, el Partido Revolucionario Institucional acaba de pagar, apenas la semana pasada, el último pago a Alkino, pero pagó de acuerdo a lo que terminaba en el mes de noviembre, entonces pasó el mes de diciembre, y dos meses más, esos dos meses más no le pagó los intereses que merecía.

Si no le cobra estos intereses, porque se tardó estos dos meses más, lo consideraría una aportación de una entidad mercantil, puesto que en los términos del contrato no se cumplieron en el sentido de que es una especie de días de gracia, en los cuales no pagó el partido político y no pagó la diferencia en intereses que estaban pactados.

El consejero del poder legislativo Fernando Belaunzarán argumentó que un préstamo puede servir también para financiar alguna actividad. Por tanto, se podría usar para financiar. Otro aspecto que dijo es que si Alkino no le cobró intereses al PRI por el retraso del pago se podría considerar una aportación al partido. El desglose que realizó el diputado Belaunzarán puntualizó de forma minuciosa los aspectos que estuvieron implícitos en el caso. Cada participación de Belauzarán aportaba elementos para aplicar la normatividad de forma eficaz al caso.

\section{El consejero Baños hizo uso de la palabra para contestar al diputado} Fernando Belaunzarán.

No hay contratación de un financiamiento, es lo que usted quiere que le diga, no opino eso, creo en otra cosa diferente, mi interpretación es distinta. Lo que ocurrió fue simplemente que se cubren los esquemas de implementación del servicio de la dispersión del dinero contratado. Ese es el punto.

Ahora, que los intereses deben tener algún tratamiento, quizá sí, no me parece que sea una aportación, me parece que son parte de los gastos, no me parece que deba ir, por cierto, a los gastos de campaña, porque la parte de lo principal, que es el dinero dispersado, que son los 66 millones de pesos, 50 millones y medio a las federales y 16 millones a las locales es la parte de lo principal, lo otro es, desde mi punto de vista accesorio, y eso tendría que ser informado y sumado al partido político en un esquema diferente, quizá los gastos ordinarios. 
El consejero Marco Antonio Baños continuó con sus razonamientos en defensa de que no existió un financiamiento. Con respecto a los intereses que le condonó Alkino al PRI el consejero Baños dijo que se podrían sumar a los gastos ordinarios. Marco Antonio Baños siguió con su postura de abogar de que fue un préstamo.

\section{Posteriormente el consejero Alfredo Figueroa Fernández realizó una nueva intervención para decir que:}

También es indispensable, en mi opinión, se ordene a la Unidad de Fiscalización, primero, declarar fundado el procedimiento administrativo como una propuesta concreta, en un Resolutivo adicional, el procedimiento sancionador incoado contra el Partido Revolucionario Institucional, con fundamento en el artículo 342, párrafo 1, inciso 1), del Código Federal de Instituciones y Procedimientos Electorales por incumplir las reglas establecidas para la comprobación del destino de los recursos de los partidos políticos.

Es mi opinión que debe establecerse la vista correspondiente para el Informe de Gastos de Campaña, es decir, para que se cuantifique en el Informe de Gastos de Campaña, además de la parte proporcional erogada, con motivo del contrato en relación a los intereses. Ambos elementos estarán presentes en esa vista. Adicionalmente, creo que debe señalarse en otro procedimiento, en su momento, la vista a la propia Unidad de Fiscalización sobre esta argumentación.

Estamos hoy analizando el origen y destino de los recursos de los partidos políticos. Eso es lo que está juzgando esta autoridad y clasificando, poniendo, ahora sí en claro, en qué se gastó este recurso.

El consejero Figueroa dijo que su voto sería en el sentido de declarar fundado el procedimiento en contra del PRI por no comprobar el destino de los recursos. También pidió que la Unidad de Fiscalización hiciera otra vista al rubro de gastos de campaña debido a que los intereses perdonados al PRI se podría catalogar como gastos de campaña.

El consejero Lorenzo Córdova Vianello tomó la palabra para decir:

Solamente pido la palabra para dos puntos adicionales a la reflexión. El primero tiene que ver con este argumento que se ponía sobre la mesa, a propósito de la reclasificación y el estado de indefensión, se decía, en que se dejaría al partido político. El argumento aquí me parece que abriría la puerta, de darlo por bueno, a un problema no menor. Es cierto que esta autoridad electoral está proponiendo, está determinando que el monto de los 50 y tantos millones involucrado se compute como gasto de campaña y no como gasto ordinario, como lo pretendía originalmente el partido político denunciado, como lo ha sostenido sobre la mesa.

Porque si diéramos por bueno el tema de que la reclasificación, como se le ha llamado, del tipo de gasto supone o implica un estado de indefensión para el partido político, lo que estaríamos abriendo es la posibilidad que cuando llegara el Informe de Gastos Ordinarios, el Informe Anual, el partido político nos diría, con toda razón: "Oigan, no compruebo esto porque esto no es un gasto ordinario, tú mismo me dijiste que era un gasto de campaña". 
El consejero Córdova habló sobre del derecho de réplica a que fue expuesto del PRI al hacer una reclasificación de algunos contratos de gastos ordinarios a gastos de campaña. El argumento brindado por el consejero Córdova dejó del lado que la única instancia que posee facultades de reclasificación es la Unidad de Fiscalización. No existe alguna regla dentro del reglamento de fiscalización que hable sobre la reclasificación. Sin embargo, la Unidad de Fiscalización posee un proceso de fiscalización donde si existiese alguna anormalidad se reporta al partido que la cometió para darle oportunidad de réplica.

El plazo es de cinco días hábiles dentro de los cuales la Unidad llama a los representantes del partido ante el IFE para explicarles la situación y oír sus argumentos. Se brinda la oportunidad de audiencia al partido por escrito y oralmente. Se pueden realizar dos rondas para este proceso. Los atributos contables de la Unidad de Fiscalización para reclasificar los datos que presenten los partidos políticos. Además de que pueden existir reuniones de los miembros de la Unidad de Fiscalización con los participantes del Consejo General del IFE para indagar sobre algunas preguntas que tengan. Por tanto, la participación del consejero Córdova no tomó en cuenta los aspectos técnicos anteriormente señalados, pero sí permiten al partido tener derecho de audiencia para que se le aclare la reclasificación y a los miembros del Consejo General para conocer el proceso de la investigación.

El representante del PAN ante el consejo General del IFE, Rogelio Carbajal Tejada, posteriormente dijo:

Sostengo que este financiamiento en su origen es ilegal y lo sostengo por una sencilla razón, porque los ingresos no entraron jamás a una cuenta del Partido Revolucionario Institucional, como lo dice el Reglamento de Fiscalización. Evidentemente el destino de un financiamiento ilegal también lo es y por eso no está comprobado. 
voy a empezar por la no información, por la violación al artículo 326 del Reglamento de Fiscalización, que obliga a todos los partidos políticos a informar cinco días después de la contratación de cualquier préstamo, crédito, financiamiento, como quieran llamarle, al Instituto Federal Electoral, cosa que no sucedió. ¿Por qué no sucedió?

Porque evidentemente el origen no es un financiamiento de una empresa mercantil. Por eso no sucedió ese Informe y por eso seguimos a la fecha esperando esa información de parte del Partido Revolucionario Institucional. A partir de ahí, evidentemente no hay un ingreso a sus cuentas y a partir de ahí, no hay un egreso de los monederos de sus cuentas y por lo tanto no hay facturas a nombre del Partido Revolucionario Institucional. Nadie haciendo esto en su sano juicio va a ir a pedir en la disposición de ese dinero una factura a nombre del Partido Revolucionario Institucional para comprobar el gasto, pues evidentemente que no lo va a hacer y no lo va a hacer porque el financiamiento es ilegal, porque el origen es ilegal.

\section{El representante del PAN, dijo que era un financiamiento ilegal.} Además de que el PRI no había presentado los informes que le requería la Unidad de Fiscalización.

\section{El diputado Fernando Belaunzarán habló acerca de algunos aspectos del caso.}

Lo racional es hacer lo sencillo y lo legal, eso es lo razonable. Lo que aquí nos están tratando de convencer es que lo razonable o esto fue hacer lo complicado y lo ilegal. Si a cualquier persona o entidad o institución le preguntas ¿Quieres conseguir unas tarjetas de pre pago? ¿Cómo le haces?

El camino más sencillo es ir a un banco, ir a una empresa que tenga recurso, etcétera, que se dedique a eso. El Partido Revolucionario Institucional hizo lo contrario, en "su verdad", pero además lo hizo violando la ley y los que conocemos eso, sabemos que el Partido Revolucionario Institucional, es conocedor de la legislación electoral y no iba a cometer estos gazapos tan fuertes a la legislación, a menos de que fuera una situación desesperada y aquí lo que estaban era buscando su coartada.

¿Por qué digo lavado de dinero? Porque eran recursos ilegales los que estaban en esa cuenta de Inizzio, Monex y que estaban fondeando a esas estructuras del Partido Revolucionario Institucional. Si ese es dinero ilegal y luego el Partido Revolucionario Institucional simplemente lo paga con el financiamiento público, eso se llama lavado de dinero con recursos públicos, hacer del dinero ilegal, dinero legal. De ese tamaño es la decisión; y lo peor de todo es que se justifique, con una historieta que no puede convencer a nadie, con dos dedos de frente.

El diputado Fernando Belaunzarán volvió a sus argumentos acerca de la lógica jurídica sobre el financiamiento. También el diputado habló acerca de la posibilidad de que el dinero hubiese provenido del lavado de dinero. Aunque es difícil comprobar este punto dado por el consejero Belaunzarán, es probable que no fuera comprobada debido a que estos temas no están dentro de las facultades de la Unidad de Fiscalización. Ricardo Mejía Berdejas realizó sus últimos comentarios sobre al caso Monex. 
Únicamente para concretizar, nosotros plantearíamos en base al artículo 326 del Reglamento de Fiscalización que, partiendo del supuesto que hubo un financiamiento, un crédito, un préstamo de Alkino al Partido Revolucionario Institucional y que no fue reportado conforme a la legislación, ahí hay ya una infracción. Eso sería el primer punto.

Lo otro, coincidimos, no queda claro el origen de los recursos y nos parece que se construye toda esta versión, para justificar un financiamiento ilegal, una triangulación que se hizo a través de varias empresas, que fueron empresas fachada. Lo otro que coincidimos con los Consejeros Electorales es el destino del gasto. Por todas estas razones, creemos que es procedente que este Consejo General tome a bien determinar una sanción, tomando en cuenta la reincidencia.

La participación del consejero del poder legislativo Ricardo Mejía Berdejas habló acerca del préstamo que fue un financiamiento y se cometió una infracción a la normatividad. Además de que puso en duda el origen de los recursos.

En su última intervención de la sesión del 23 de enero de 2013, el representante del PRI ante el IFE, José Antonio Hernández Fraguas dijo lo siguiente:

Por supuesto para insistir en el tema y comentar en función de lo que adujo el Consejero Electoral Lorenzo Córdova, de que había duda, cuando menos en la revisión de las pruebas que nosotros adjuntamos, simplemente decir que hay un principio que establece que habiendo duda, se absuelve, no se condena.

Que se revisara esto y simplemente que se tome en cuenta por supuesto lo establecido en el artículo 346 del Reglamento de Fiscalización en donde, si no se cumpliera nosotros creemos que no se está respetando nuestro derecho de audiencia y que, en todo caso, la sanción no sería aplicada legalmente.

El consejero presidente del IFE, Leonardo Valdés sometió a votación la resolución general del proyecto, fue aprobada por unanimidad.

La votación en lo particular del segundo resolutivo con respecto a declarar infundado la ilegalidad del financiamiento de la campaña del PRI. La votación fue aprobado por siete votos a favor y uno en contra. (A favor votaron Marco Antonio Baños Martínez, Lorenzo Córdova Vianello, Alfredo Figueroa Fernández, Francisco Javier Guerrero Aguirre, María Marván Laborde, Benito Nacif Hernández, Leonardo Valdés Zurita. En contra votó María Macarita Elizondo Gasperín. No estuvo en esta votación el consejero Sergio Ramírez García). El voto de la mayoría de los consejeros fue apoyar a este resolutivo, dando legalidad al origen del 
dinero. Esta votación puso de manifiesto que a pesar de que algunos consejeros se declararon cautos con respecto a la investigación realizada por la Unidad de Fiscalización finalmente la apoyaron en este aspecto.

El tercer resolutivo fue sobre hacer que la Unidad de Fiscalización revisara nuevamente la legalidad del contrato de Alkino-PRI. Cuando se realizó la votación, hubo empate a cuatro votos. (Los consejeros que votaron a favor fueron Lorenzo Córdova, Alfredo Figueroa, María Marván y Benito Nacif. Marco Antonio Baños Martínez, María Macarita Elizondo, Francisco Javier Guerrero, Leonardo Valdés sufragaron en contra de dar vista a la Unidad de Fiscalización para verificar el contrato de PRI con Alkino).

Debido al igual número de votos entre los que estaban a favor y los que se encontraban en contra en este tercer resolutivo, Leonardo Valdés solicitó al consejero Sergio García Ramírez votar para que desempatara la votación. El consejero García sufragó a favor de dar vista a la Unidad de Fiscalización sobre la legalidad del contrato Alkino-PRI. El total del resultado fue cinco votos a favor y cuatro en contra. Este punto es relevante dentro de la facultades de la Unidad de Fiscalización está verificar la legalidad de los contratos, que son sus herramientas básicas de trabajo. Es decir, no ejerció en plenitud sus atribuciones laborales la Unidad.

Luego se presentó la votación del cuarto resolutivo sobre el impacto y costos asociados al financiamiento, esto es, rechazar hacer un nuevo resolutivo para incluir los intereses y comisiones en el rubro de gastos de campaña. Fueron tres votos en contra y seis a favor. (Los consejeros que votaron a favor fueron Marco Antonio Baños Martínez, María 
Macarita Elizondo Gasperín, Sergio García Ramírez, Francisco Javier Guerrero Aguirre, Benito Nacif Hernández, Leonardo Valdés. Los que votaron en contra Lorenzo Córdova Vianello, Alfredo Figueroa y María Marván Laborde).

Por otra parte, la Unidad se extralimitó en sus funciones debido a que sus facultades que le atribuye el COFIPE en el artículo 81 de realizar "los informes [que] especificarán las irregularidades en que hubiesen incurrido los partidos políticos en el manejo de sus recursos; el incumplimiento de su obligación de informar sobre la aplicación de los mismos y, en su caso, propondrán las sanciones que procedan conforme a la normatividad aplicable", si este es el caso, sería necesario que la Unidad de Fiscalización hubiera especificado el motivo de que no apareció este rubro en la proyecto de resolución ni la sanción correspondiente.

Después se votó sobre dar vista a la Unidad de Inteligencia Financiera. Se aprobó por unanimidad. Posteriormente, se votó acerca de dar vista a Comisión Nacional Bancaria y de Valores. También fue aprobada por unanimidad.

Posteriormente se votó para que la FEPADE revisara la información disponible sobre el caso. La votación que se hizo marcó ocho votos a favor $y$ uno en contra. (Marco Antonio Baños Martínez, Lorenzo Córdova Vianello, Alfredo Figueroa Fernández, Sergio García Ramírez, Francisco Javier Guerrero Aguirre, María Marván Laborde, Benito Nacif y Leonardo Valdés estuvieron a favor de dar vista a la FEPADE. Únicamente la consejera María Macarita Elizondo Gasperín se opuso). También se votó por dar vista al SAT. El voto del consejo general fue unánime. Esta últimas cuatro votaciones, mostraron que todavía habían 
cuestiones que no estaban suficientemente aclaradas y que por tanto era necesario recurrir a estos organismos para que investigaran más a profundidad. Este hecho demostró que la celeridad por realizar esta sesión dejó elementos poco claros de la investigación que posteriormente se tendrían que subsanar con otra investigación.

\subsection{Conclusiones.}

Las conclusiones que se desprenden de esta capítulo cuarto, fue que existieron visos de ilegalidad en el caso Monex. Es preciso mencionar que los consejero electorales tuvieron posiciones encontradas y similares en ciertos temas.

El aspecto que se puede resaltar es que la mayoría de los miembros del Consejo General del IFE argumentaron con elementos que presentó la Unidad de Fiscalización. Es decir, usaron los razonamientos jurídicos dados por la Unidad que si bien realizó su trabajo no contenían una trama lógica que pudiera rastrear minuciosamente la historia del caso Monex. En cambio, los representantes del PRD y PAN y los consejeros del poder legislativo que pertenecían al PRD y PAN (Fernando Belaunzarán y Ricardo Mejía Berdejas del PRD y Javier Corral Jurado por el PAN) trataron de brindar argumentos jurídicos y ligarlos a posibles explicaciones que dieran coherencia al proceso. Con respecto a la forma en cómo se abordó la ley y la interpretación de la misma se puede concluir que existieron deficiencias en la interpretación del consejero Baños. 
Mientras que otros consejeros, como María Macarita Elizondo y Alfredo Figueroa mostraron claridad en casos en los que la ley no menciona debido a que se basaron el principio de interpretación armónica con otras leyes.

Con respecto a la primera resolución que versó sobre declarado infundado el procedimiento por voto unánime. Este primer dictamen que declaró infundado la queja de rebase de topes de campaña, dejó dudas acerca de la legalidad del proceso. Esto se debió a que la Unidad de Fiscalización no quiso llegar al fondo del asunto del rebase de topes de campaña. Otro rasgo de ilegalidad es que el Consejo General no sumó ni hizo el prorrateo, que hubiera podido sumar más al gasto de campaña de Peña Nieto y hubiera podido dar un rebase de topes de campaña.

El segundo resolutivo fue declarar sin fundamento la queja de ilegalidad del financiamiento de la campaña de Peña Nieto. En este segundo dictamen denota que el Consejo General del IFE a pesar de que no menciona la normatividad nada acerca del financiamiento de una empresa mercantil a un partido político, decidió no hacer uso de la interpretación armónica y sistemática de la ley electoral con la Constitución Política. Esta omisión de parte de la mayoría de los consejeros electorales, excepto de María Marván, permitió no sentenciar al PRI por este hecho. Aunque había pruebas dentro de la investigación de la Unidad de Fiscalización de un financiamiento ilícito, el Consejo General decidió no actuar, generando que se diera por legal un recurso que no lo era.

El tercer resolutivo que fue acerca de dar vista a la Unidad de Fiscalización para verificar la legalidad del contrato Alkino-PRI. La 
comprobación de la legalidad del contrato fue una desatención de la Unidad de Fiscalización. La legalidad del contrato es un aspecto básico que debió revisar la Unidad de Fiscalización y no esperar a que el Consejo General le recomendara que debía hacerlo. Este resolutivo muestra la omisión en que incurrió la Unidad y que generó una distorsión del caso y por tanto una legalidad dudosa. Además que se denota un trabajo deficiente con otras instancias como SAT, Condusef en la verificación de las empresas y sus contratos con la Unidad de Fiscalización.

El cuarto resolutivo que trató sobre rechazar otro resolutivo para incluir los intereses y comisiones como gastos de campaña. Este punto del dictamen dejó constancia de que la investigación hecha por la Unidad de Fiscalización no indagó acerca de la condonación de intereses de la empresa al PRI. Los más de 2 millones de pesos pudieron haberse sumado como aportación a los gastos de campaña, sin embargo no se adicionaron. Este hecho demuestra que existió una omisión en la labor del Consejo General con respecto a este punto causando una violación a la ley y a la legalidad.

Los resolutivos quinto, sexto y séptimo fueron sobre dar vista a la Unidad de Inteligencia Financiera, SAT, a la Comisión Bancaria y de Valores y a la FEPADE. Estos dictámenes del Consejo General del IFE mostraron que los consejeros electorales no estaban satisfechos con los datos aportados por la investigación de la Unidad de Fiscalización. La pregunta que surge es si no estaban seguros los consejeros electorales de la información ¿por qué apresurarse a tener una sesión para discutir 
el caso Monex si los huecos informativos podían distorsionar la legalidad en favor del PRI?.

Los tres últimos dictámenes demuestran que se distorsionó la legalidad debido a que no se investigaron delitos como lavado de dinero, rebase de topes de campaña, empresas 'fantasmas' que también estaban implícitos en el caso. Además estos resolutivos delatan que la cooperación interinstitucional no fue la más óptima, ya que se volvió a requerir la participación de otras instituciones gubernamentales, cuando supuestamente ya se había llevado a cabo el requerimiento de información a las instituciones federales por parte de la Unidad de Fiscalización.

Por otra parte, la premura con que llevó a cabo la sesión del 23 de enero de 2013 en el Consejo General del IFE y los resultados de la investigación que hizo la Unidad entregara el proyecto el día 21 de ese mismo mes, puso al descubierto que una parte de los consejeros electorales no habían tenido la oportunidad de leer el documento completo. Por tanto, carecían de los elementos propios para argumentar de forma documentada los pormenores del caso Monex. Este hecho contribuyó a que la discusión no profundizara en partes esenciales del proyecto de la Unidad y que se dejaran fuera aspectos claves que revelaban detalles finos que pudieron conducir a la investigación por otros rumbos.

Otro elemento a destacar es la no intervención que tuvieron tanto el consejero presidente Leonardo Valdés y el consejero Sergio García Ramírez. El consejero García Ramírez no participó en la discusión debido a que tenía relación con una de las partes acusadas. Sólo votó en 
el momento en que pidieron su intervención debido a que en un punto de la votación hubo un empate. La actuación del consejero García fue adecuada debido a que se abstuvo de tener parte en la discusión. Mientras que el consejero presidente, Leonardo Valdés no se saben las razones de su mutismo a lo largo de toda la discusión. Además faltó que dirigiera la discusión porque por momentos se perdía los puntos trascendentes de la discusión.

El tema de reflexión es la actuación de la Unidad de Fiscalización. Un aspecto que se puede resaltar son las omisiones técnicas en el quehacer de la Unidad. En varias intervenciones que realizaron los representantes del PRD y PAN leyendo segmentos del documento que presentó la Unidad, el PRI reconoció en sus documentos que entregó a la Unidad que obtuvo un financiamiento de Alkino.

Es importante escribir lo que Israel García Íñiguez, de la Auditoria Superior de Jalisco menciona "el no haber tomado como base, en la creación de la Unidad [de Fiscalización], el modelo institucional de Entidad de Fiscalización Superior, que a fin de cuentas marca la pauta del sistema de fiscalización superior nacional, [...], porque establece un área de riesgo de injerencia de factores políticos en el actuar técnico de la Unidad". ${ }^{165}$ Esto es debido a que se puede revisar y modificar el proyecto de los órganos técnicos por parte de los integrantes políticos dando lugar a la politización de las cuentas públicas. Es decir, se está de acuerdo con el proyecto siempre y cuando haya una negociación política para aprobar un documento de una instancia técnica. Este es el caso de

\footnotetext{
${ }^{165}$ García Íñiguez, Israel. "Fiscalización de los recursos de los partidos políticos". Sufragio .Revista especializada en derecho electoral.No.8. Diciembre 2011-Mayo 2012. Año. 2012. Pág. 135.http://www.juridicas.unam.mx/publica/librev/rev/sufragio/cont/2/ens/ens13.pdf.
} 
la Unidad de Fiscalización. Con los resolutivos $2^{\circ}, 3^{\circ}$ y $4^{\circ}$ se realizó esta acción. 


\section{Conclusión.}

La finalización de esta tesis recoge las ideas principales que surgieron a lo largo de la misma. En primer término se puede decir que el funcionamiento de la democracia no se puede entender sin el rol que juegan los recursos económicos en una contienda política. Las elecciones para cargos de elección popular precisan de recursos. Para evitar el uso impropio de los fondos, existen los organismos autónomos electorales para financiar y fiscalizar los recursos. Estos mismos organismos proveen del dinero necesario para que los partidos políticos desarrollen sus actividades ordinarias y de campaña.

Además los organismos electorales autónomos poseen la función de garantizar que los procedimientos y normas que deben de regir un proceso democrático se lleven a cabo. De este aspecto depende que se cumpla la calidad de una democracia según los términos de Leonardo Morlino. El rubro de la calidad de la democracia eficiente que está conformada por el Estado de derecho es indispensable para una buena democracia. Pero se debe de tener en cuenta que el capital humano tienen un peso trascendente en la dinámica institucional que puede rebajar la calidad de la democracia.

Sin embargo, la historia y la dinámica política e institucional con que cuenta México hace indispensable la revisión de la misma.

Es preciso decir que el proceso democrático que experimentó el país, generó instituciones electorales que siguen siendo pilar fundamental de la democracia. Estas instituciones como lo es el Instituto Federal Electoral 
(IFE) son clave para estudiar la calidad de la democracia. La reforma electoral en materia de fiscalización 2007 ha pretendido brindar certeza al proceso democrático.

En el proceso político, el IFE convive con estructuras institucionales (partidos políticos) que contienen prácticas institucionales del antiguo sistema político. Es decir, la calidad de la democracia en México, vista desde el IFE, pelea por hacer valer valores democráticos en instituciones políticas que conservan componentes autoritarios. Por tanto, la calidad de la democracia posee una perspectiva limitada de cumplimiento en el sistema político mexicano.

El IFE se halla en medio en un sistema de partidos que pretende aminorar los avances democráticos que han logrado muchos actores políticos.

La estructura que conforma al Consejo General del IFE y a la Unidad de Fiscalización que se analizó en esta tesis, dejó constancia que poseen los elementos necesarios para su adecuado funcionamiento. La autonomía administrativa que tiene la Unidad de Fiscalización genera que los procesos contables puedan considerarse confiables y sin presiones de tipo políticos. También es preciso mencionar que las facultades institucionales y jurídicas que posee esta Unidad hacen que tenga un margen de maniobra amplio para desarrollar su tarea de fiscalización. En teoría se cubren los requisitos precisos para cumplir sus responsabilidades de forma cabal.

El Consejo General del IFE es la máxima instancia de toma de decisiones electorales del país. La estructura y las facultades 
institucionales y jurídicas provocan que tenga asegurado una actividad propicia a los requerimientos democráticos del país. Sin embargo, los aspectos humanos y políticos poseen un aspecto relevante en la marcha del Consejo General del IFE.

Por otra parte, el capítulo tercero que trató acerca del valor de la imparcialidad que debe regir el actuar del IFE mostró resultados interesantes. La manera en cómo se asignan los puestos del Consejo General del IFE generó que haya lealtades partidistas por parte de los consejeros hacia los partidos políticos que los propusieron.

El perfil académico y profesional de los consejeros electorales que estuvieron en el periodo en que se discutió el caso Monex fue más modesto que el de anteriores selecciones del Consejo General del IFE. Ningún consejero o consejera destacaba por su personalidad en el ámbito público como un sobresaliente ciudadano independiente o como un distinguido académico.

También otro aspecto que afectó indirectamente la imparcialidad del caso fue que el titular de la Unidad de Fiscalización es designado por los Consejeros Electorales. La manera más adecuada de asignar al titular de la Unidad sería que otra instancia como un conjunto de universidades públicas lo nombraran debido a que el Consejo General está partidizado y ese hecho repercute en quién será el encargado de dicha junta. Por tanto, se dedujo que la Unidad no se adentró plenamente en la investigación como en los resolutivos segundo, tercero y cuarto. Además dejó puntos clave como el rebase de topes de campaña fuera de la pesquisa y también en la verificación de legalidad de los contratos presentados por el PRI. 
En el aspecto del principio de imparcialidad en la discusión de los consejeros electorales fue marcada por la actuación mesurada de los consejeros. No obstante, la calidad de las discusiones dejó mucho que desear debido a que los consejeros electorales no generaron el ambiente propicio para provocar un entendimiento más preciso del caso. A través de sus participaciones, la mayoría de los consejeros demostraron que no habían leído el documento o sólo lo habían leído en parte. Este hecho provocó que al no tener la información necesaria, sus intervenciones carecieran del respaldo informativo $\mathrm{y}$ por tanto distorsionaran la imparcialidad.

Los representantes de los partidos políticos y los consejeros del poder legislativo, trataron de inducir a los consejeros electorales a ir más allá de los datos que presentó la Unidad de Fiscalización y darles un sentido metódico. Es decir, aplicar la lógica jurídica. A partir de una serie de posibles hipótesis ir apuntado hacia una sola conjetura a través de las pruebas presentadas. En otras palabras, organizar la información de tal manera que contenga una sistematización que haga coherente la explicación del asunto. Este aspecto destacó por su ausencia en varios consejeros electorales.

A nivel institucional se debe destacar que la actuación del Consejo General del IFE fue displicente y omitió parte de su labor. Quizá se debió procurar poner más insistencia en investigar más a fondo dando el tiempo preciso para que la Unidad de Fiscalización y las otras instancias gubernamentales (SAT, CONDUSEF, etc.) hubieran hecho su labor con la precisión y puntualidad adecuadas. Pero se decidió por parte del Consejo General que fuera hecha la sesión extraordinaria del 23 de 
enero de 2013 sin estar confirmado completamente los datos presentados por la Unidad de Fiscalización.

Otro elemento del principio de imparcialidad fue el informe que presentó la Unidad de Fiscalización. Esta Unidad si bien cuenta con profesionales expertos en materia contable, los resultados que generaron en su informe, que fue comentado y usado por los representantes de los partidos políticos, dejó entrever una serie de deficiencias de carácter técnico como se vio en el resolutivo tercero sobre la legalidad del contrato Alkino-PRI. Además es preciso que se mencione que por la prisa con que fue hecho el proyecto haya existido una serie de omisiones legales como el rebase de topes de campaña, el prorrateo (división y asignación del dinero investigado en campaña presidencial, estatal, municipal).

Si bien el proyecto que presentó la Unidad de Fiscalización con respecto al caso Monex fue aprobado por la mayoría de los consejeros electorales con respecto al rubro del origen de los recursos, sin embargo se tuvo que dar vista nuevamente a otras instancias como SAT, FEPADE, la Unidad de Inteligencia Financiera y la Comisión Nacional Bancaria y de Valores. Este hecho, puso en evidencia que no estaban conformes con la pesquisa realizada por la Unidad de Fiscalización. Aunque en el discurso los consejeros electorales loaron la indagación pero en la práctica mostraron que deseaban que se revisara otra vez. La pregunta sería: ¿cuál fue la razón por la que usaron los datos de la Unidad de Fiscalización en el área del origen de los recursos si después los pondrían en cuestión? 
La legalidad en la investigación realizada por la Unidad de Fiscalización pudo generar indicios de imparcialidad en la decisión tomada por los consejeros electorales. También es preciso mencionar que el informe que presentó la Unidad de Fiscalización fue difuso conceptualmente. Los argumentos presentados por los consejeros electorales mostraron confusión terminológica respecto a conceptos tales como financiamiento, préstamo, etc. La claridad en términos hubiera resultado en un proceso más certero y con visos de legalidad comprobada.

Dentro del principio de legalidad que debe regir la actuación del IFE, se encontró que el proceder técnico de la Unidad de Fiscalización creó ciertas desavenencias en la realización del debate en el consejo general.

Por otra parte, las conclusiones a que llegó la Unidad de Fiscalización dejaron incertidumbres legales debido a que pasaron por alto elementos que hubiesen dado más componentes de análisis jurídico además de que se hubiesen detectado otras posibles violaciones a la ley como que no se incluyó los intereses y comisiones perdonados por la empresa al PRI como gastos de campaña del resolutivo cuarto. La presentación de la conclusiones por parte de la Unidad dejó que desear debido a que mostró unos resultados escuetos y sin la adecuada conexión entre ellos. No existió una explicación precisa de los hechos. La omisión que se llevó a cabo en este aspecto determinó que se deteriorara el principio de legalidad.

También es preciso mencionar que en torno a la legalidad se dejó dudas acerca de la investigación que realizó la Unidad de Fiscalización, debido a que en su pesquisa encontró que los domicilios fiscales de 
algunas empresas no existían o eran ocupados por negocios de otros giros. Ante tal caso, se debió notificar al Consejo General que se trataban de empresas fantasmas, y aunque la Unidad de Fiscalización no posee atribuciones para decidir la situación jurídica de una empresa mercantil, hubiera sido coherente que se hubieran puesto en duda la declaraciones de las empresas involucradas en el caso. Existió una omisión a este respecto por parte de la Unidad.

Comparando la información proporcionada por la Unidad de Fiscalización con respecto al caso Monex y la Comisión sobre el mismo asunto en la Cámara de Diputados se obtuvieron dos resultados distintos. Con respecto al tope de campañas el Consejo General del IFE decidió que no se había rebasado el tope de gastos de campaña mientras que el reporte que presentó la Comisión sostuvo que se había rebasado el tope de gastos trece veces, es decir con un monto de 4599 947834 pesos. ${ }^{166} \mathrm{La}$ diferencia entre una investigación y otra es notable.

También en la pesquisa hecha por la Comisión del caso Monex en la Cámara de Diputados encontró que también había participado tarjetas de Banamex, Bancomer, Wal-Mart, Santader entre otras. La Unidad de Fiscalización no halló lo mismo, sino que fueron más restringido sus hallazgos.

También es menester señalar como un rasgo de legalidad, el consejero Sergio García Ramírez no participó en las discusiones del caso por causa de tener nexos con una parte involucrada. Ni tampoco lo iba hacer hasta que se presentó un empate en una votación. Dejó muchas dudas la

\footnotetext{
${ }^{166}$ Cervantes, Jesusa. "Peña gastó en campaña 13 veces más del tope: comisión Monex". Proceso. 11 de marzo de 2014. En http://www.proceso.com.mx/?p=367033
} 
nula intervención en la discusión del consejero presidente, Leonardo Valdés debido a que no tenían ningún impedimento legal.

Con respecto a la interpretación armónica de leyes ejercida cuando no existe un artículo que mencione la sanción específica de un caso, fue sobresaliente la participación de los consejeros Elizondo y Figueroa. Estos consejeros trataron de hacer compatibles el espíritu de la ley constitucional con los valores rectores de la vida política nacional. Si bien no había una norma escrita que prohibiera el financiamiento de parte de empresas mercantiles como se propuso en el segundo resolutivo acerca de infundar la ilegalidad del financiamiento recibido por el PRI, la interpretación de los motivos para vedar la participación de privados en el ámbito de financiamiento electoral mostró acierto de parte de estos consejeros además de oficio en su labor.

Quedó al descubierto por parte de los representantes de los partidos políticos y consejeros del poder legislativo que la labor hecha del proyecto de resolución fue acometida por la Unidad de manera poco escrupulosa. La trama lógica que hubiese podido aportar una pesquisa más profunda de esta instancias y de las gubernamentales, pudo haber representado mayor apego a la legalidad.

Esta compatibilidad discursiva que realizaron los consejeros del poder legislativo perredista y panistas y representantes de los partidos opositores al PRI, donde presentaron los elementos jurídicos y los acontecimientos producidos del caso Monex hubieran dado asertividad política y jurídica sí los consejeros electorales los hubieran utilizado. 
A nivel institucional se percibió que hubo una premura por realizar la sesión del 23 de enero de 2013. Esta rapidez por discutir el caso Monex hizo que la investigación de la Unidad de Fiscalización fuera entregada de forma precipitada dos días antes de la sesión indicada. Una reflexión del autor de estas líneas piensa que hubiese dado más certeza al proceso legal ejercido contra el PRI, hubiese sido la inclusión en la mesa del contador Alfredo Cristalinas Kaulitz encargado de la Unidad de Fiscalización para responder y aclarar las dudas y preguntas.

Por último, es preciso mencionar que uno de los aspectos que refleja el caso Monex es la poca capacidad institucional que prevalece en el país para hacer valer el Estado de derecho en el ámbito de fiscalización electoral.

La aplicación efectiva del Estado de derecho dentro del modelo de la calidad de la democracia en el rubro de la democracia efectiva que se aplica en México resulta ineficiente para las necesidades de la actividad partidaria en el país. Las omisiones y carencias de las autoridades electorales por hacer valer el Estado de derecho son palpables. 


\section{Bibliografía}

-Ackerman. John, Estructura institucional para la rendición de cuentas: Lecciones internacionales y reforma futuras, Auditoria Superior de la Federación-Cámara de Diputados, Serie cultura de la rendición de cuentas, Libro 9, México, 2006, 55 p.

-Ackerman, John, "Autoridad Descentralizada y desarrollo político: la dinámica institucional de la rendición de cuentas”, En Isunza, Ernesto y Alberto Olvera (coord.), Democratización, rendición de cuentas y sociedad civil,CIESAS-Miguel Ángel Porrúa, México, 2010, Pp. 293-322.

- Ackerman, John, "Elecciones 2012: prueba de fuego". En Calva, José Luis (coord.), La agenda de la democracia en México,Juan Pablos Editor y Consejo Nacional de Universitarios, México, 2012, pp. 65-76.

-Agiss Bitar, Fernando,Fiscalización de los recursos de los partidos políticos, Serie Temas Selectos de Derecho Electoral, TEPJF, México, 2008, 50 p.

-Aguayo, Sergio,Vuelta en U,1 Edición,Editorial Taurus. México, 2010, $400 \mathrm{p}$.

-Andrade Sánchez, Eduardo,Derecho constitucional,Oxford University Press, México, 2008, 574 p.

-Andrade Sánchez, Eduardo,Derecho electoral, Oxford University Press México, México, 2012, 378 p. 
-Attili Cardamone, Antonella y Luis Salazar,Más allá de la transición. Los cambios políticos en México. 1977-2000,UAM-I-Miguel Ángel Porrúa, México, 2010, 166 p.

-Ayala Camargo, María Guadalupe,Los partidos políticos en la transición a la democracia en México, 1997-2000, Tesis de Maestría. Facultad de Ciencias Políticas y Sociales, UNAM, México, 2002, 110 p.

-Aziz, Alberto y Jorge Alonso, "Votos, reglas y partidos", En Aziz Nassif, Alberto (Coord.),México al inicio del siglo XXI. Democracia, ciudadanía y desarrollo, $1^{\circ}$ Edición. CIESAS-Miguel Ángel Porrúa, México, 2003, pp. 65-96.

-Aziz Nassif, Alberto y Jorge Alonso, México una democracia vulnerada $1^{\circ}$ Edición,CIESAS-Miguel Ángel Porrúa, México, 2009, 339 p.

- Aziz Nassif, Alberto, "El desencanto de una democracia incipiente", En Rodríguez Araujo, Octavio (Coord.),México ¿nuevo régimen político?, $1^{\circ}$ Edición, Siglo XXI Editores, México, 2009, pp.9-62.

-Baños, Marco Antonio, “El IFE: palanca del cambio político en México”, En Centro para el Desarrollo Democrático (coord.), Instituto Federal Electoral. 20 años, Volumen II,IFE, México, 2010, pp. 224-307.

-Barquín Álvarez, Manuel, "El financiamiento de los partidos políticos en México, en la reforma de 1993”, En Pérez Fernández del Castillo, Germán y Arturo Alvarado (Coord.),La voz de los votos. Un análisis crítico de las elecciones de 1994, Miguel Ángel Porrúa-Flacso, México, 1995, pp. 39-58. 
-Barry, Brian,Teorías de la justicia, $1^{\circ}$ Edición, Gedisa Editorial, Barcelona, 1995, $429 \mathrm{p}$.

-Becerra, Ricardo, Pedro Salazar y José Woldenberg,La reforma electoral de 1996: una descripción general, FCE, México, 1997, 237 p.

- Bobbio, Norberto,El futuro de la democracia, $2^{\circ}$ Edición en español, FCE, México, 1996, 214 p.

-Bobbio, Norberto,Liberalismo y democracia, $11^{\circ}$ reimpresión, FCE, México, 2006, 115 p.

-Cansino, César,La transición mexicana, 1977-2000, $1^{\circ}$ Edición, Centro de Estudios en Política Comparada, México, 2000, 368 p.

-Cárdenas Gracia, Jaime,Lecciones de los asuntos PEMEX y Amigos de Fox. $1^{\circ}$ Reimpresión, IIJ, México,2004, 190 p. Disponible en formato http://biblio.juridicas.unam.mx/libros/3/1366/1.pdf

-Carrasco Daza, Constancio, "La integración del Consejo General del Instituto Federal Electoral. Una decisión judicial para materializar la norma constitucional", Justicia electoral, $4^{\circ}$ época, Vol. I, No. 10, JulioDiciembre 2012, pp. 495-509.

-Cejudo, Guillermo,La construcción de un nuevo régimen de rendición de cuentas en las entidades federativas, Serie Cultura de la Rendición de Cuentas, ASF, México, 2009, 96 p.

-Cervantes, Jesusa, "Peña gastó en campaña 13 veces más del tope: comisión Monex",Proceso, 11 de marzo de 2014, en http://www.proceso.com.mx/?p=367033 
-Constitución Política de los Estados Unidos Mexicanos, Cámara de Diputados del H. Congreso de la Unión. http://www.diputados.gob.mx/LeyesBiblio/pdf/1.pdf

-Córdova Vianello, Lorenzo, "Equidad y contienda política. Un balance de quince años", En Calva, José Luis (coord.), La agenda de la democracia en México,Juan Pablos Editor y Consejo Nacional de Universitarios, México, 2012, pp. 53-64.

-Cruz Cruz, María Irene,Fiscalización al financiamiento público otorgado a los partidos políticos, Tesis de licenciatura, Facultad de Derecho. UNAM, México, 2009, 112 p.

-Cuellar Vázquez, Angélica, "Estado del arte de la sociología jurídica en América Latina", En de la Garza Toledo, Enrique (Coord.),Tratado latinoamericano de sociología, $1^{\circ}$ Edición,Anthropos Editorial-UAM-I, España, 2006, pp.264-277.

-Culebro Moreno, Jorge, "Reforma administrativa y nuevas reformas de organización. El diseño e implementación de organismos reguladores de mercado", En Culebro Moreno, Jorge. (Editor),Nuevas fronteras de la regulación. Transformación y diseño institucional,UAM-C y Juan Pablos Editor, México, 2009, pp. 17-46.

-Dahl, Robert,Un prefacio a la teoría de la democracia, Ediciones Gernika, México, 1987, 197 p.

-Dahl, Robert,La poliarquía, Editorial Tecnos, España, 1989, 228 p. 
-Dahl, Robert,Los dilemas del pluralismo democrático, $1^{\circ}$ Edición en español, Editorial Alianza y Consejo Nacional para la Cultura y las Artes, México, 1991, 210 p.

-Dahl, Robert,La democracia y sus críticos, $2^{\circ}$ Edición, Ediciones Paidós,España, 1993, 476 p.

-Dahl, Robert,La democracia. Una guía para los ciudadanos, TaurusAlfaguara, España, 1999, 246 p.

-De la Cruz Carrillo, Omar.,"La designación de los consejeros electorales del IFE en 2010: entre la autonomía y las cuotas partidarias", Iztapalapa. Revista de ciencias sociales y humanidades, No. 73, Año 33, JulioDiciembre 2012, pp. 127-148.

-Díaz Sandoval, Mariela,Las disputas discursivas a favor de la democracia en los órganos autónomos: un análisis del Banco de México y del Instituto Federal Electoral,Tesis de doctorado,FLACSO México, 2011, 264 p.

-Díaz Ortiz, Ángel, “Autoridades administrativas electorales”. En Tribunal Electoral del Poder Judicial de la Federación,Apuntes de derecho electoral: una Contribución institucional para el conocimiento de la ley como valor fundamental de la democracia,TEPJF, México, 2000, pp. 154200.

-Emmerich, Gustavo Ernesto y Alejandro Favela Gavia, "Democracia vs. Autoritarsimo", En Emmerich Gustavo y Víctor Alarcón Olguín (coord.) Tratado de ciencia política, Primera edición, UAM-I y Anthropos Editorial, España, 2007, Pp. 297. 
-Emmerich, Gustavo Ernesto, "Los organismos electorales locales: panorama, contribución a la democracia y perspectivas", En López Montiel, Gustavo (Coord.), Los procesos electorales desde la perspectiva local, $1^{\circ}$ Edición, Colección Sinergia, IEDF, México, 2009, pp.19-50.

-Fernández Ruiz, Graciela,Argumentación y lenguaje jurídico. Aplicación al análisis de una sentencia de la Suprema Corte de Justicia de la Nación, $1^{\circ}$ Edición,IJJ-UNAM, México, 2011, 226 p. Disponible en formato: http://biblio.juridicas.unam.mx/libros/libro.htm?l=3016.

-Ferrajoli, Luigi, "Pasado y futuro del Estado de derecho", En Carbonell, Miguel, Wistano Orozco,Rodolfo Vázquez. (Coord.),Estado de derecho. Conceptos, fundamentos y democratización en América Latina, $1^{\circ}$ Edición, UNAM-ITAM-Siglo XXI Editores, México, 2002, pp. 187-204.

-Ferrajoli, Luigi,Principia Juris. Teoría del derecho y la democracia,Editorial Trotta, Madrid, 2011,676 p.

-Fox, Jonathan, "Transparencia y rendición de cuentas", En Ackerman, John (Coord.),Más allá del acceso a la información,IIJ-Siglo XXI Editores-Universidad de Guadalajara-Cámara de Diputados-CETA, México, 2008, pp. 174-198.

-Fragoso Sánchez, María Lina,Fiscalización al financiamiento de los recursos de los partidos políticos nacionales y su órgano fiscalizador, Tesis de licenciatura, Facultad de Derecho, UNAM, México, 2011, 80 p.

-Fundación Internacional para Sistema Electorales,Aplicación de la reforma electoral de 2007/2008 en México desde una perspectiva internacional comparada,Primer InformeIFES, 2009, 106 p. 
-Garavito, Rosa Albina, "La raquítica democracia mexicana o ¿dónde estamos en la transición?, En Anguiano, Arturo (Coord.),Después del 2 de julio ¿dónde quedó la transición?. Una visión desde la izquierda,UAMX, México, 2001, pp. 21-39.

-García Íñiguez, Israel, "Fiscalización de los recursos de los partidos políticos",Sufragio .Revista especializada en derecho electoral,No.8, Diciembre 2011-Mayo 2012, Año. 2012,pp.120136.http://www.juridicas.unam.mx/publica/librev/rev/sufragio/cont/2/ens/ens1 3.pdf.

-González Gramajo, Fernando Javier,Lógica jurídica, Instituto de Investigaciones Jurídicas, Universidad Rafael Landívar, Guatemala, 2010,397 p. http://biblio3.url.edu.gt/Publi/Libros/Logica-Juridica/04.pdf

-Guerrero, Claudia, (2012, 18 de julio), "Reconoce tricolor uso de tarjetas". Reforma,Pág. 6.

-Guerrero, Claudia, (2012, 26 de julio), "Gasta tricolor \$66.3 millones el 1 de julio",Reforma,Pág. 5 .

-Guerrero, Eduardo,Fiscalización y transparencia del financiamiento a partidos políticos y campañas electorales. Dinero y democracia, Auditoria Superior de la Federación, Serie: cultura de la rendición de cuentas,México, 2003,72 p.

-Huchim, Eduardo, "Elecciones: avances, fallas y simulación", En Rodríguez Araujo, Octavio (Coord.),México ¿nuevo régimen político?, Siglo XXI Editores, México, 2009, pp. 151-196. 
-Huntington, Samuel,La tercera ola, $1^{\circ}$ Edición, Ediciones Paidós, España, 1994, 329 p.

-Instituto Federal Electoral,Resolución del Consejo General del Instituto Federal Electoral procedimiento de queja en materia de fiscalización de los recursos de los partidos políticos nacionales, (Q-UFRPP 58/12), 228 p.

-Instituto Federal Electoral. Unidad de Fiscalización de los Recursos de los Partidos Políticos,Resumen de la resolución por la que desahoga el caso MONEX-TARJETAS, $14 \mathrm{p}$.

-Islas Montes, Roberto, "Sobre el principio de legalidad", En Anuario de derecho constitucional latinoamericano, Fundación Konrad AdenauerUNAM, Uruguay, 2009, pp. 97-108.

-Isunza Vera, Ernesto,"El reto de la confluencia”, En Dagnino, Evelina, Alberto Olvera y Aldo Panfichi (Coord.),La disputa por la construcción democrática en América Latina, $1^{\circ}$ Edición,CFE-CIESAS-Universidad Veracruzana, México, 2006, pp. 275-329.

-Jaramillo, Juan, "Los órganos electorales supremos", En Zovatto, Daniel y Dieter Nohlen (Comp.),Tratado de derecho electoral comparado de América Latina, $2^{\circ}$ Edición, FCE-IFE IDEA Internacional y Tribunal del poder judicial de la Federación, México, 2007,pp. 371-436.

-Jaramillo Navarrete, Daniela Gisell,El cambio de integrantes del consejo general del IFE 2003,Tesina de licenciatura,UAM-I, México, 2004, 99 p. 
-Jímenez Ruiz, Francisco Javier,Financiamiento a partidos políticos y teoría de juegos,Miguel Ángel Porrúa-Universidad Juárez Autónoma de Tabasco-Cámara de Diputados, México, 2005,452 p.

-López Ayllon, Sergio y Mauricio Merino, "La rendición de cuentas en México: perspectivas y retos", En Merino, Mauricio, Sergio López y Guillermo Cejudo (Coord.),La estructura de la rendición de cuentas en México, [en línea] IIJ, México, 2010, pp. 1-28. Formato html, Disponible en Internet: http://www.bibliojuridica.org/libros/libro.htm?l=2800)

-Lujambio, Alonso, "México", En Carrillo Manuel, Alonso Lujambio, Carlos Navarro y Daniel Zovatto (coord.),Dinero y contienda políticoelectoral, $1^{\text {a }}$ Edición, FCE-IFE, México, 2003, 370 p.

-Lujambio, Alonso, "La fiscalización de los gastos de los partidos políticos”, En Zovatto, Daniel, Dieter Nohlen (comp.). Tratado de derecho electoral comparado en América Latina, 2da. Edición, FCE-IFE-IDEA Internacional y Tribunal del poder judicial de la Federación, México, 2007, pp. 821-835.

-Martínez Gil, José Pablo y Patricia Macías, "Autoridades electorales jurisdiccionales en México (TEPJF)", En Corona Nakamura, Luis Antonio y Adrián Joaquín Miranda Camarena.(comps.),Derecho Electoral Mexicano. Una visión local: Jalisco, Marcial Pons, Ediciones Jurídicas y Sociales, S.A, Madrid, 2010,pp. 123-150.

-Méndez, Irma, "Competencia y competitividad electoral: dos conceptos clave de la transición democrática",Polis,Vol. 1, 2003, pp. 27-48. 
-Méndez, Irma,Transición a la democracia en México. Competencia partidista y reformas electoral 1977-2003,Fontamara-FLACSO México,2006, 313 p.

-Méndez, Irma, "Transición y consolidación democrática en México: ¿es posible una regresión?,Revista Facultad de Derecho,No. 247, Enero-Junio, 2007, pp. 63-79.

-Méndez, Irma, "Calidad de las elecciones y los institutos electorales estatales: las elecciones a gobernadores en 2010 en México", En López Montiel, Gustavo y Rosa María Mirón Lince.(coord.), Los estados en el 2010. El nuevo mapa del poder regional, $1^{\circ}$ Edición, UNAM-IEEGGernika-Tecnológico de Monterrey, México, 2011, pp. 595-607.

-Merino, Mauricio,La transición votada. Crítica a la interpretación del cambio político en México, $1^{\circ}$ Edición, FCE, México, 2003, 246 p.

-Meyer, Lorenzo,El Estado en busca del ciudadano,Editorial Oceano, México, 2005, 199 p.

-Morlino, Leonardo,Democracias y democratizaciones, $1^{\circ}$ Edición, Centro de Investigaciones Sociológicas, Madrid, 2009, 252 p.

-Morlino, Leonardo, "Calidad de la democracia. Notas para su discusión", En Cansino, César y Israel Covarrubias (Coord.), Por una democracia de calidad, $1^{\circ}$ Edición, Centro de Estudios de Política Comparada-Educación y cultura, Asesoría y Promoción, S.C, México, 2007, pp. 27-53.

-Murayama, Ciro, "Financiamiento a los partidos políticos: el nuevo modelo mexicano", En Salazar, Pedro y Lorenzo Córdova (coord.),Estudios 
sobre la reforma electoral de 2007. Hacía un nuevo modelo, TEPJF, México, 2008, pp. 263-287.

-Nohlen, Dieter,Sistemas electorales y partidos políticos, $1^{\circ}$ Edición, FCEUNAM, México, 1994, 404 p.

-O’Donnell, Guillermo, “Accountability horizontal: la institucionalización política de la desconfianza política”,Revista Española de Ciencia Política, No. 11, Oct. 2004, pp. 11-31.

-O’Donnell, Guillermo,Disonancias. Críticas a la democracia,Prometeo Libros, Argentina, 2007, 202 p.

-OEA-PNUD, Nuestra democracia, $1^{\circ}$ Edición, OEA-PNUD-IFE-CFEGobierno de España-AECIE, México, 2010. 258 p.

-Patiño Camarena, Javier,Derecho electoral mexicano, $3^{\circ}$ Edición, Editorial Constitucionalista, México, 1996, 556 p.

-Patiño Camarena, Javier,Nuevo derecho electoral mexicano 2006, $8^{\circ}$ Edición, [en línea] IIJ, UNAM, 2006, 836 p. Formato html. Disponible en Internet: http://biblio.juridicas.unam.mx/libros/libro.htm?l=1833.

-Pérez Manzano, Karina, Estudio de las facultades y responsabilidades del IFE como Organismo Autónomo Constitucional y la perspectiva electoral hacia el 2012,Tesis de licenciatura, Facultad de Ciencias Políticas y Sociales, UNAM, México, 2011, 174 p.

-Portilla Martínez, Adolfo Sergio,Los problemas del financiamiento a los partidos políticos .Una comparación entre México y España,Tesis de 
licenciatura, Facultad de ciencias políticas y sociales, UNAM, México, 2011, $180 \mathrm{p}$.

-Pérez Portilla, Karla,Principio de igualdad: alcances y perspectivas, UNAM-Consejo Nacional para Prevenir la Discriminación, México, 2005, 261 p. Formato html. Disponible en Internet: http://biblio.juridicas.unam.mx/libros/libro.htm?l=1589

-Prieto Sanchís, Luis,Apuntes de teoría del derecho, $2^{\circ}$ Edición, Editorial Trotta, España,2007, 331 p.

-Przeworski, Adam,Democracia e mercado. No leste Europeu e na AméricaLatina,Dumará Distribuidora de Publicaciones, Brasil, 1994, 270 p.

-Przeworski, Adam,Sustainable democracy, $1^{\circ}$ Reimpresión, Cambridge University Press,Estados Unidos,1996, 141 p.

-Przeworski, Adam,Democracy andthe limits of Self-government, Cambrigde University Press, Estados Unidos, 2010, 200 p.

-Reveles Vázquez, Francisco, "Repensando el papel de los órganos electorales en el proceso de democratización de México", En López Montiel, Gustavo (Coord.),Los procesos electorales desde la perspectiva local, $1^{\circ}$ Edición, Colección Sinergia IEDF, México, 2009,pp. 51-79.

-Sartori, Giovanni,Teoría de la democracia. El debate contemporáneo, $3^{\circ}$ Reimpresión, Tomo I, Alianza Editorial, España, 2001, 305 p.

-Sartori, Giovanni,Teoría de la democracia. Los problemas clásicos, $3^{\circ}$ Reimpresión, Tomo II, Alianza Editorial, España, 2005, 626 p. 
-Sartori, Giovanni, ¿Qué es la democracia?,2 $2^{\mathrm{a}}$ Reimpresión, Taurus, México, 2005, 483 p.

-Schedler, Andreas, ¿Qué es la rendición de cuentas?, $8^{\circ}$ Edición, Cuadernos de Transparencia, IFAI, México, 2008, 39 p.

-Schmitt, Karl,Teoría de la constitución, Alianza Editorial, España, 1982, $377 \mathrm{p}$.

-Schumpeter, Joseph,Capitalismo, socialismo e democracia, Editora Fundo de Cultura,Brasil , 1961, 487 p.

-Soto Cabrera, Ricardo,Autonomía e imparcialidad del IFE,Tesina, Departamento de Sociología,UAM-I, México, 1999, 95 p.

-Torres González, Ana María,El tránsito de las reformas electorales en México: de la Comisión Federal Electoral al Instituto Federal Electoral (1946-2007),Tesis de Maestría, Facultad de Ciencias Políticas y Sociales, UNAM, México, 2011, 214 p.

-Ugalde Calderón, Filiberto Valentín, "Órganos constitucionales autónomos",Revista del Instituto de la Judicatura Federal,No. 29, 2008, pp. 253-264.

-Valldecabres Ortiz, María Isabel,Imparcialidad del juez y medios de comunicación,Universitat de València y Tirant lo Blanch, Valencia, 2004, $765 \mathrm{p}$.

-Valdés, Leonardo, "Elecciones y legislación electoral", En Baca Olamendi, Laura, (et al.) Léxico de la política, $1^{\circ}$ Reimpresión, CFEFLACSO-CONACYT-Heinrich Böll Stifung, México, 2004, 831 p. 
-Vidal de la Rosa, Godofredo,Desigualdad social y equidad política. Ensayos críticos de teoría democrática, $1^{\circ}$ Edición, UAM Azcapozalco y Miguel Ángel Porrúa, México, 2012, 236 p.

-Woldenberg, José,La construcción de la democracia,Plaza y Janés Editores, México, 2002, 380 p.

-Woldenberg, José, "El cambio electoral. Casi 30 años", En Attili, Antonella (Coord.),Treinta años de cambios políticos en México, $1^{\circ}$ Edición,UAM-I, Miguel Ángel Porrúa, Cámara de Diputados (XIL legislatura), México, 2006, pp. 47-66.

-Woldenberg, José, "Estampas de la reforma”, En Salazar, Pedro y Lorenzo Córdova (coord.) Estudios sobre la reforma electoral de 2007. Hacía un nuevo modelo, TEPJF, México, 2008, pp. 27-43.

-Woldenberg, José,"La ciudadanización del IFE”, En Centro para el Desarrollo Democrático (Coord.),Instituto Federal Electoral 20 años,CDD, México, 2010, pp. 156-177.

-Zovatto, Daniel, "El financiamiento electoral: subvenciones y gastos", En Zovatto, Daniel, Dieter Nohlen (comp.),Tratado de derecho electoral comparado en América Latina, 2da. Edición, FCE-IFE-IDEA Internacional y Tribunal del poder judicial de la Federación, México, 2007, pp.744-793. 